\title{
A integração de teorias e técnicas na prática clínica em terapia familiar
}

Tese apresentada à Faculdade de Filosofia, Ciências e Letras de Ribeirão Preto da Universidade de São Paulo, como parte dos requisitos para obtenção do grau de Doutora em Psicologia

Área de Concentração:

Psicologia em Saúde e Desenvolvimento

Orientadora: Profa. Dra. Carla Guanaes-Lorenzi

Ribeirão Preto 
Autorizo a reprodução e divulgação total ou parcial deste trabalho, por qualquer meio convencional ou eletrônico, para fins de estudo e pesquisa, desde que citada a fonte.

Paula-Ravagnani, Gabriela Silveira de.

A integração de teorias e técnicas na prática clínica em terapia familiar. Ribeirão Preto, 2019. 219 p. : Il. ; 30 cm

Tese de Doutorado, apresentada à Faculdade de Filosofia, Ciências e Letras de Ribeirão Preto/USP. Área de Concentração: Psicologia.

Orientadora: Guanaes-Lorenzi, Carla.

1. Terapia familiar. 2. Terapia de casal. 3. Prática clínica. 4. Construcionismo social. 
Paula-Ravagnani, Gabriela Silveira de.

A integração de teorias e técnicas na prática clínica em terapia familiar

Tese apresentada à Faculdade de Filosofia, Ciências e Letras de Ribeirão Preto da Universidade de São Paulo, como parte dos requisitos para obtenção do grau de Doutora em Psicologia

Aprovado em:

Banca Examinadora

Prof. Dr.

Instituição Assinatura

Prof. Dr.

Instituição Assinatura

Prof. Dr.

Instituição Assinatura 

Este estudo foi desenvolvido junto ao Laboratório de Estudos e Pesquisas em Práticas Grupais da Universidade de São Paulo (LAPEPG-USP)

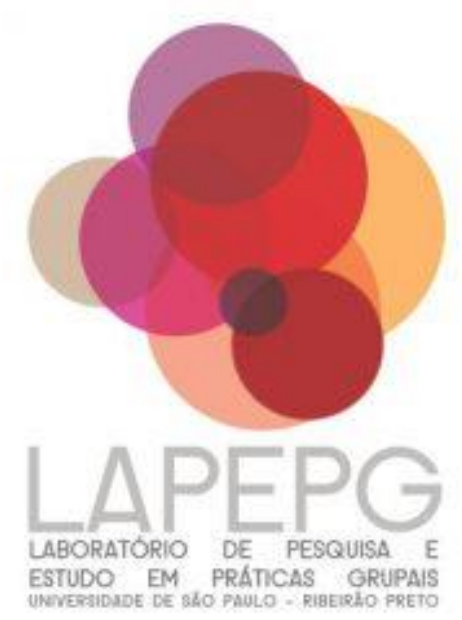

O presente trabalho foi realizado com apoio da Fundação de Amparo à Pesquisa do Estado de São Paulo (FAPESP) mediante a concessão de bolsa de doutorado, com vigência de janeiro de 2016 a dezembro de 2018 (Processo no ${ }^{\circ}$.2015/21316-1).
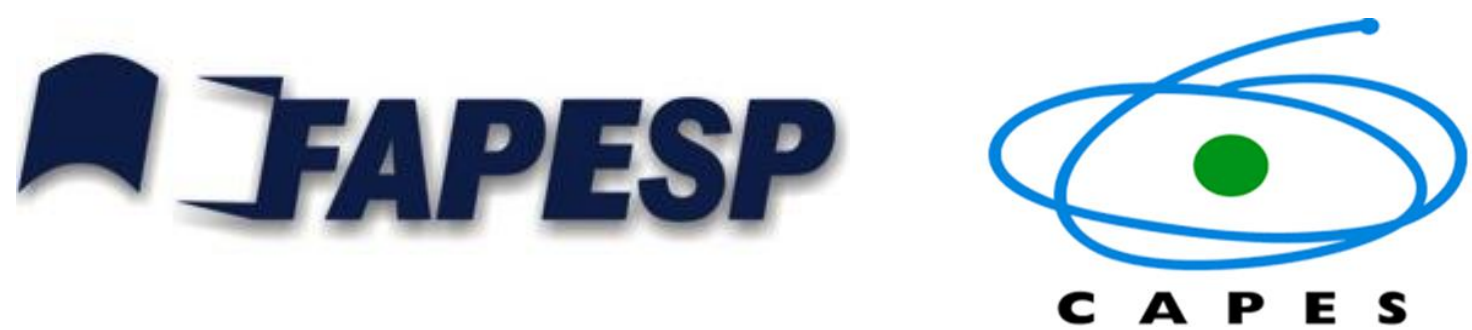

Ao querido tio Rodolfo, sempre em minhas lembranças.

Ao Lucas e à Catarina. Para mim, bússola e porto seguro. 



\section{Agradecimentos}

À Profa. Dra. Carla Guanaes-Lorenzi, por esses anos de intenso aprendizado, em uma parceria que se consolidou pela admiração e respeito, e hoje se torna uma alegre amizade. Orientadora e professora dedicada, competente, criativa, sensível, será sempre um modelo para mim. À você, minha gratidão e imenso carinho.

À Fundação de Amparo à Pesquisa do Estado de São Paulo (FAPESP) e à Coordenação de Aperfeiçoamento de Pessoal de Nível Superior (CAPES), pelo apoio financeiro que permitiu que eu me dedicasse exclusivamente à pesquisa e formação acadêmica (Processo FAPESP no. 2015/21316-1).

À Anna e Lina, terapeutas-participantes, co-terapeutas, co-pesquisadoras e cocriadoras dessa pesquisa, pela dedicação e imenso esforço que envolveram todas as etapas de participação na pesquisa. Espero, sinceramente, que possa contribuir para seu cotidiano como terapeutas. Aos clientes Luis e Ligia; Vivian e Igor; Raul, Renata e Amanda, meus agradecimentos por ter-nos aberto o espaço da intimidade de suas vidas, para que ali pudéssemos fazer alguma diferença.

À Profa. Dra. Rosana Lázaro Rapizo, parceira no desenvolvimento dessa pesquisa, pela abertura, sensibilidade, e primoroso olhar clínico que enriqueceu nosso trabalho.

Ao Prof. Dr. Manoel Antônio dos Santos e Profa. Dra. Maria Aparecida Crepaldi, pela participação na banca do Exame de Qualificação. Sua leitura atenta e cuidadosa nos ofereceu contribuições marcantes para a finalização da tese.

Aos participantes do Laboratório de Estudo e Pesquisa em Práticas Grupais LAPEPG-USP, que desde 2012 são meus companheiros de estudos, reflexões e aprendizagens na vida acadêmica. Em especial, agradeço a Giovanna Cabral, Marilia Palacio, Thais Cintra, Pedro Martins, Luíza Menezes, Gabriela Martins, Domitila Gonzaga, Malu Fatureto e Letícia Pozzer.

Ao Prof. Rolf Sundet, Ph.D., pelas longas conversas e inusitados insights sobre o sentido de ser terapeuta. E, principalmente, pelo carinho com que me recebeu em sua casa.

À Profa. Dra. Clarissa Mendonça Corradi-Webster, pela orientação durante o Estágio PAE, abrindo-me novos horizontes sobre a prática em Psicologia e a docência. Foram meses recheados de aprendizado e também gostosos sorrisos. 
À Secretaria do Departamento de Psicologia e ao Serviço de Pós-Graduação da Faculdade de Filosofia, Ciências e Letras de Ribeirão-Preto, pelo apoio institucional e esclarecimentos.

Aos funcionários do Ponto de Apoio FAPESP, que sempre me ajudaram de forma ágil e cordial.

Aos meus queridos colegas de trabalho e alunos, que me ensinam o sentido da coerência entre o falar e o fazer, e me inspiram a querer ser uma pessoa melhor.

Aos meus pais, Paulo e Sandra, e minha irmã Indiara, por me acompanharem, guiarem e acalentarem em todos os meus dias. Trago-os dentro de mim, em tudo o que faço e sou.

Ao Lucas, marido amoroso, que traz luz à minha jornada e alegria aos meus dias, e arrebatou meu coração com a força do encontro genuíno.

À Catarina, que me mostrou que o amor é misterioso, impermanente, profundo, místico, vivo, e a cada dia leva-me a conhecer o divino e o humano que existe em $\operatorname{mim}$.

Aos meus amigos, amigas e familiares, que trazem à minha vida o colorido, as gargalhadas e o porto-seguro para o qual é sempre bom voltar. Em especial, agradeço à Lívia, Karen, Édna, Giovanna, Marisa, Gabriel, Gael, Vó Nilda, Silvana, Paula, Mariana, Antônio e Regiane.

À Lucy, amada companheirinha das minhas caminhadas ao entardecer e dos momentos de preguiça no jardim. 


\section{RESUIMO}

Paula-Ravagnani, G. S. (2019). A integração de teorias e técnicas na prática clínica em terapia familiar. Tese de Doutorado. Faculdade de Filosofia, Ciências e Letras de Ribeirão Preto, Universidade de São Paulo, Ribeirão Preto.

A utilização concomitante de diferentes modelos teóricos e técnicos faz parte do cotidiano na prática clínica em terapia familiar (TF), e a expansão e sofisticação destas práticas levantam questões sobre os critérios utilizados para o uso, pelos profissionais, das diferentes teorias e técnicas. O objetivo deste estudo qualitativo é compreender como terapeutas familiares integram teorias e técnicas em seu cotidiano de atendimentos clínicos. Especificamente, buscamos descrever os recursos utilizados por terapeutas em atendimentos e dar visibilidade às suas justificativas teóricas, articulando-as com a literatura. O delineamento teórico-metodológico é baseado na pesquisa-ação colaborativa, e tem como referência os pressupostos do construcionismo social. Participaram deste estudo duas terapeutas familiares e seus clientes atendidos em terapia de família ou casal, cujas sessões foram audiogravadas e transcritas. O contexto de realização da pesquisa foi o consultório das participantes. As principais informações do corpus foram provenientes de duas fontes: atendimentos clínicos e interlocução pós-atendimento realizada com cada participante. A construção e análise dos dados basearam-se na alternância entre ciclos de ação e reflexão. A pesquisadora e cada terapeuta-participante trabalharam em co-terapia atendendo uma família ou casal, registrando sistematicamente informações de 10 sessões. Após o término do atendimento, as terapeutasparticipantes tiveram acesso à análise das sessões e fizemos uma interlocução, norteada pelo interesse na construção de justificativas para suas ações. Cada interlocução foi transcrita e analisada. O processo analítico gerou cinco categorias: ações exploratórias, ações de construção de visões relacionais, ações de construções da comunicação em contexto e ações de orientação familiar. Exemplificamos cada ação com trechos de sessão e demos visibilidade aos recursos teóricos técnicos que as embasaram. Por fim, construímos sentidos sobre a integração, e a prática clínica das terapeutas-participantes foi descrita em termos de três dimensões: sensível ao contexto e às pessoas, engajada em produzir conhecimento com as pessoas, $\mathrm{e}$ autorreflexiva. Essas dimensões indicam que a integração de recursos não é uma posição que a terapeuta escolhe ocupar a priori, uma vez que não é possível afirmar, antecipadamente, quais recursos serão utilizados em um atendimento. O estudo indica que a integração na prática clínica ocorreu de maneira relacional e responsiva às especificidades das pessoas e contextos. Concluímos que a integração envolve uma abertura do/a terapeuta para o caos e a imprevisibilidade dos encontros humanos, e questionamos a viabilidade de um/a terapeuta "purista", ou seja, fiel a um único modelo, uma vez que o uso de múltiplos recursos pode ampliar as possibilidades de conexão e construção de mudança com os clientes. Apresentamos, por fim, contribuições da pesquisa para o campo profissional: fomentamos debates acerca das noções de coerência, consistência e rigor na prática clínica, oferecemos uma releitura dos resultados de modo a dialogar mais diretamente com o cotidiano da clínica, e apresentamos modelos de investigações a serem realizadas tanto em contextos acadêmicos quanto em institutos de formação. (FAPESP, processo no ${ }^{\circ}$. 2015/21316-1)

Palavras-chave: Terapia familiar; terapia de casal; prática clínica; construcionismo social. 



\begin{abstract}
Paula-Ravagnani, G. S. (2019). Integration of theories and techniques in the practice of family therapy. Doctoral Dissertation. Faculty of Philosophy, Sciences and Letters of Ribeirão Preto, University of São Paulo, Ribeirão Preto.
\end{abstract}

The concomitant use of different theoretical and technical models is part of daily practice in family therapy (TF), and the expansion and sophistication of these practices raise questions about the professionals' criteria to use different theories and techniques. The aim of this qualitative study is to understand how family therapists integrate theories and techniques in their daily clinical practice. Specifically, we aim to describe the resources used by therapists in family therapy sessions, and reflect on their theoretical justifications, articulating them with the literature. The theoreticalmethodological design is based on collaborative action research, and the social constructionism's premises for research. The participants were two family therapists and their clients attended in family therapy, whose sessions were audio-recorded and transcribed. The sessions were carried out at the therapists' offices. Most part of the corpus information came from two sources: family therapy sessions and conversations carried out with each therapist after ten sessions. The data construction and analysis were based on alternations between cycles of action and reflection. The researcher and each therapist worked in co-therapy in a family therapy process, and information from 10 sessions was systematically recorded. After the end of each therapeutic process, the therapists had access to the sessions' analysis and we had a conversation guided by the interest in constructing justifications for their actions. Each conversation was transcribed and analyzed. The analysis process generated five categories: exploratory actions, actions for the construction of relational visions, actions for the construction of contextual communication, and actions for family orientation. The categories were exemplified with session excerpts, in which we emphasized the technical and theoretical resources behind them. Finally, we propose reflections about integration, and the therapists' clinical practice were described in terms of three dimensions: sensitive to clients and context, producing knowledge with people, and self-reflexive. These dimensions indicate that integration is not a position that the therapist chooses a priori, since it is not possible to predict which resources will be used in a session. The study indicates that integration occurred relationally and responsively to specificities of people and contexts. We conclude that integration involves a therapist's openness to chaos and the unpredictability of human encounters, and we question the viability of a "purist" therapist, that is, practices based on a single model, since the use of multiple features enhance the possibilities to create generative dialogues. Finally, we present research contributions to the professional field: we instigate debates about the notions of coherence, consistency and rigor in clinical practice, offer a description of the results that dialogue more directly with clinical daily practice, and present investigation models for both academic researches and training institutes (FAPESP, process $n$. 2015/21316-1).

Key words: Family therapy; couple therapy; clinical practice; social constructionism. 



\section{LISTA DE QUADROS}

Quadro 1 - Etapas de ação e reflexão envolvidas na produção e análise dos dados 71

Quadro 2 - $\quad$ Exemplo de uma Tabela Descritiva das Categorias ...................... 75

Quadro 3 - $\quad$ Níveis de análise dos dados e participantes envolvidos .............. 81

Quadro 4 - $\quad$ Definição das categorias analisadas ............................................... 86

Quadro 5 - $\quad$ Temáticas que compõem a categoria “ações exploratórias" ........ 87

Quadro 6 - $\quad$ Temáticas que compõem a categoria "ações de construção de 104

Quadro 7 - Temáticas que compõem a categoria "ações de construção da comunicação em contexto" .......................................................... 141

Quadro 8 - Temáticas que compõem a categoria "ações de orientação familiar" ........................................................................... 151

Quadro 9 - $\quad$ Síntese das informações discutidas na análise dos dados ........... 159

Quadro 10 - $\quad$ Ferramenta I para investigações na prática de TF ....................... 165

Quadro 11 - $\quad$ Ferramenta II para investigações na prática de TF ...................... 166

Quadro 12 - Ferramenta III para investigações na prática de TF .................... 166

Quadro 13 - Recursos conversacionais para a prática do terapeuta familiar .. 171 



\section{LISTA DE ABREVIATURAS E SIGLAS}

TF - $\quad$ Terapia familiar

USP - $\quad$ Universidade de São Paulo

FFCLRP - Faculdade de Filosofia, Ciências e Letras de Ribeirão Preto

ABRATEF - Associação Brasileira de Terapia Familiar 



\section{Sumário}

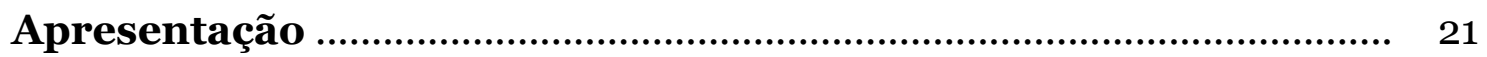

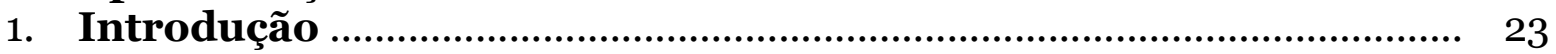

1.1. Narrativas possíveis sobre a história da terapia familiar ........................... 24

1.2. O campo da terapia familiar e de casal .................................................... $\quad 25$

1.3. A relação do/a terapeuta com técnicas e modelos teóricos ........................ 35

1.4. A integração na prática clínica em terapia familiar ................................... 38

1.5. Justificativa e objetivos ........................................................................... 44

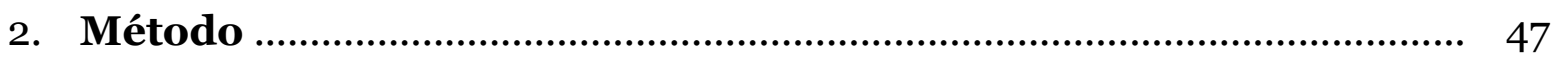

2.1. Orientação construcionista social .......................................................... 47

2.2. Pesquisa-ação: processos colaborativos na pesquisa ……………………. 50

2.3. Criando rigor e qualidade no processo de pesquisa .................................. 53

2.4. Construção do contexto da pesquisa ......................................................... 55

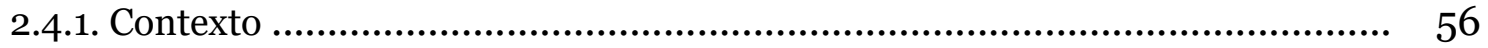

2.4.2. Participantes ........................................................................................... 58

2.4.2.1. A construção da relação com Anna .............................................................. 60

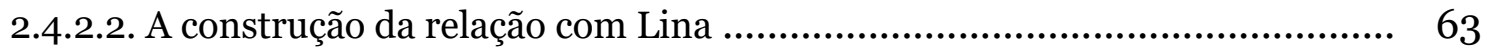

2.4.2.3. A construção da relação com os clientes .................................................... 65

2.4.2.4. A terapeuta pesquisadora ……………………..................................... 67

2.5. Produção e análise dos dados: ciclos de ação e reflexão ............................. 68

2.6. Aspectos éticos .................................................................................. 77

2.7. A construção estética do capítulo de análise e discussão ............................ 79

3. Análise e Discussão ……………………………………………….... 83

3.1. O foco nas ações ................................................................................... 83

3.2. Ações em contexto: os recursos utilizados pelas terapeutas ..................... 86

3.2.1. Ações exploratórias ................................................................................... 87

3.2.2. Ações de construção de visões relacionais ...................................................... 104

3.2.3. Ações de construção da comunicação em contexto ....................................... 141

3.2.4. Ações de intervenção ............................................................................. 151

3.2.5. Construindo sentidos sobre a integração na prática clínica ............................. 158

3.2.5.1. Construindo ferramentas para investigações na prática de TF .................... 165

3.2.5.2. Construindo sentidos sobre consistência, coerência e rigor .......................... 167

3.2.5.3. Construindo orientadores para a prática clínica ……................................... 169

4. Considerações finais.................................................................................. 177

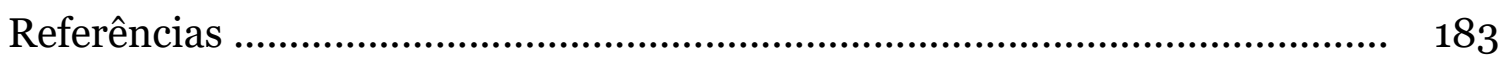

Apêndices ........................................................................................................ 197

Anexos ............................................................................................... $\quad 217$ 


\section{Apresentação}

Toda ação humana pode ser localizada como produto de uma relação do sujeito com sua história corporificada, intensamente enraizada nas experiências de vida e no entrelaçamento entre passado, presente e futuro. É sobre isso que versa essa pesquisa - Como traduzir uma ação em termos daquilo que a origina, inspira? Como, no momento do encontro entre pessoas, terapeutas familiares utilizam seus conhecimentos? Como o tempo passado, permeado por aprendizagens, vivências, contato com teorias e técnicas, presentifica-se na relação terapêutica e delineia perspectivas futuras para a vida das pessoas envolvidas?

Essa tese, enquanto ação e produto da atividade humana, também está enraizada em um passado, nos caminhos por onde pisei e nos territórios onde tenho vivido meus dias. Psicóloga, Mestre, terapeuta de família, docente, supervisora de estágio, coordenadora de um curso de formação em terapia de família de casal. E também filha, irmã, esposa, mãe, madrinha, neta, sobrinha, prima, amiga. Na conexão entre todas essas vozes, a potência e a carência de cada uma delas, essa tese foi produzida. Em todas essas facetas, os ínfimos, íntimos e cotidianos momentos que se enraízam no mais profundo do meu ser e, portanto, também falam por meio dessa tese. Sonhada, desejada, gerada, gestada, cuidada, lida, relida e finalmente parida, hoje ela passa a fazer parte das minhas histórias corporificadas e dos passos que no futuro percorrerei.

Localizada em uma trajetória de vida pessoal, esta tese dialoga com escolhas que vão desde a pequena Gabriela que brincava de ser professora de suas bonecas, à adolescente Gabriela que um dia sonhou em ser doutora, à jovem Gabriela que foi atrás de suas ambições com dedicação e esforço, até a Gabriela de hoje - como nunca, completamente inundada pelas vivências do que é ser uma família e constituir-se como pessoa nas vicissitudes dos dramas, amores e dores de estar-ser-viver família. 
Localizada em uma trajetória profissional, essa tese dialoga com caminhos traçados desde a faculdade e o início do curso de formação em terapia familiar e de casal. Jornada criadora e transformadora de minhas percepções e ações no campo da prática clínica, a minha constituição como pessoa-terapeuta inspirou a criação e execução desse estudo, e certamente está contida em cada ideia aqui apresentada.

Localizada em uma trajetória acadêmica, essa tese é um desdobramento de minha pesquisa de Mestrado, em que investigamos a difusão do construcionismo social em um grupo de terapeutas familiares, focando em como este discurso se constitui em um aporte útil para a prática clínica (Paula-Ravagnani, 2015). Nesta pesquisa, fizemos entrevistas semi-estruturadas com 13 terapeutas familiares considerados vetores de difusão do discurso construcionista social em contextos da prática clínica em TF. Concluímos que o uso das ideias construcionistas, por parte destes terapeutas, esteve atrelado à conciliação de diferentes propostas teóricas e práticas para o campo da TF, indicando-nos uma integração de recursos na prática clínica (Paula-Ravagnani, Guanaes-Lorenzi, Rasera \& McNamee, 2016; PaulaRavagnani, Guanaes-Lorenzi \& Rasera, 2017). Desse modo, esta pesquisa busca aprofundar a investigação da prática clínica em terapia familiar, e a dimensão por meio da qual construímos o corpus da pesquisa deixa de ser a narrativa sobre a prática (com o uso de entrevistas), para ser a própria prática, ou seja, os atendimentos em seu acontecimento.

Antes que o hoje se transforme em ontem, aproveito para me regozijar na imensa alegria e alva satisfação por vê-la agora, finalizada, dirigindo-me para um futuro em que não será esquecida - em meu corpo, pensamentos, emoções, diálogos e relações, essa tese estará presente, renovando-se e transformando-se. 


\section{Introdução}

Ao longo da história, a busca pelo entendimento das relações humanas tem perpassado a construção de conhecimento em múltiplos âmbitos, tais como a literatura, teatro, música, filosofia e ciência. No campo científico, a terapia familiar consolidou-se como uma modalidade terapêutica interessada em compreender as relações, consideradas o principal parâmetro de entendimento das experiências humanas (Flaskas, 2010).

Atualmente, autores e pesquisadores no campo da terapia familiar ${ }^{1}$ (TF) têm apontado uma tendência de integração na prática de terapeutas familiares, em que a prática clínica é embasada em distintas contribuições teóricas e técnicas. Tal tendência tem sido nomeada como práticas integrativas (Dickerson, 2010; Flaskas, 2010; Lebow, 2014; Smith \& Southern, 2005; Snyder \& Balderrama-Durbin, 2012), e faz parte de um movimento no campo da psicoterapia e da TF em que os terapeutas consideram que um único método ou modelo teórico é insuficiente para lidar com as demandas e desafios da prática clínica. Além disso, permite que o terapeuta coloque em seu trabalho uma marca pessoal, que geralmente envolve algum tipo de integração de modelos teóricos e práticos (Smith \& Southern, 2005).

Para delinear o objetivo desta pesquisa e o contexto que evidencia sua relevância, o texto introdutório apresenta aspectos do desenvolvimento da $\mathrm{TF}$ e fatores que mudaram a forma como os terapeutas lidam com os modelos teóricos da TF. Em seguida, apresentamos considerações acerca da integração na prática clínica, articulando-as com as justificativas e objetivos da pesquisa.

1 Em nosso trabalho, utilizamos o termo terapia familiar para designar o trabalho terapêutico com famílias em suas diferentes configurações, incluindo os casais. Esta designação do termo é consonante com as propostas de algumas associações na área, tais como a Associação Brasileira de Terapia Familiar (ABRATEF), American Family Therapy Academy (AFTA) e International Family Therapy Association (IFTA). 


\subsection{Narrativas possíveis sobre a história da terapia familiar}

Assim como em outros países, o campo da TF no Brasil constituiu-se por meio da existência de múltiplas abordagens e correntes epistemológicas, caracterizando-se por seu aspecto interdisciplinar e pela ausência de um paradigma unificador (Grandesso, 2009; Rhodes, 2012).

Alguns autores afirmam que o desenvolvimento histórico do campo tem sido compreendido e narrado dando-se destaque mais às rupturas teóricas e epistemológicas entre perspectivas e modelos que surgiram ao longo do tempo do que a partir de um olhar para as continuidades e ideias que resistiram às viradas paradigmáticas da TF (Castelló, 2016; Dallos \& Urry, 1999; Féres-Carneiro, 1996; Flaskas, 2005; Imber-Black, 2014). Desse modo, a relação do campo da TF com os conhecimentos que são nele produzidos tem sido marcada pela oposição e competitividade entre os enquadres - a cada nova proposta, há um esforço em definila por suas diferenças em relação àqueles que o precederam, acompanhado por um tom de novidade e inovação que convida a compreendê-la como melhor e mais eficaz do que outras (Flaskas, 2005). Neste contexto, os terapeutas, na ânsia por "abraçar" os novos modelos, conhecem e difundem as novas ideias sob o prisma da oposição, perpetuando o que Imber-Black (2014) nomeia como sendo uma tradição de "guerra entre modelos".

É necessário admitir, contudo, que a filiação à determinada abordagem traz consigo não apenas uma sensação de pertencimento como também a inclusão em uma rede profissional. Juntamente com a proteção e orientação que este pertencimento proporciona, há a construção de um lugar e imagem no campo profissional e na relação com o corpo social mais amplo - dificilmente encontraremos um terapeuta que nunca ouviu a indagação: “com qual abordagem você trabalha?”. Esta pergunta, em suas implicações tanto na relação com a possível clientela quanto com os pares, pressupõe não apenas a filiação e lealdade a um modelo, como também parece constituir uma pressão pela escolha que acompanha o profissional desde a formação.

Além destes aspectos profissionais e sociais que dão contorno a esta visão da TF marcada por rupturas e oposições, fatores de ordem econômica também influenciam esta dinâmica, a qual sustenta e é sustentada por uma lógica de mercado interessada 
em transformar abordagens e técnicas em mercadorias de consumo. Um exemplo da força destes interesses econômicos pode ser observado em congressos da área, onde fica evidente o pesado investimento em marketing e propaganda nos estandes de livrarias e editoras.

Além destes diferentes aspectos que influenciam e, muitas vezes, reforçam o discurso de oposição entre perspectivas, consideramos que a construção narrativa da história do campo da TF constitui-se em mais uma possibilidade de acirrar estas posições de polaridade. Tomando como importante a tarefa de apontar, neste texto introdutório, alguns momentos e transições no campo da TF, vemo-nos entrando neste terreno pantanoso que possui muitos convites à potencialização destes discursos de oposição. Atentas a estes desafios, apresentamos a história do campo a partir de uma perspectiva cronológica que indica tanto rupturas quanto continuidades e permanências de algumas ideias.

Ainda que narremos esta fase da TF a partir de uma perspectiva histórica, cronologicamente organizada, optamos por utilizar o tempo verbal no presente, entendendo que as formas de compreender as relações humanas e atuar ainda acompanham práticas clínicas de terapeutas familiares na atualidade. Neste sentido, constituem-se em discursos possíveis para a construção da prática cotidiana. Entendemos que a descrição no tempo verbal do passado pode levar a entender que estas ideias já não fazem parte do rol de práticas possíveis, convidando à postura de oposição e exclusão a que estamos nos referindo.

\subsection{O campo da terapia familiar}

O início do campo da TF é mais comumente apontado como tendo sua origem nos estudos com famílias de pacientes esquizofrênicos realizados na década de 50 por estudiosos norte-americanos liderados por Gregory Bateson, cujo interesse nos padrões de comunicação das famílias gerou importantes contribuições para a construção de teorias que passaram a entender os sintomas como sendo produzidos e sustentados nas relações entre os membros familiares (Bateson, Jackson, Haley \& Weakland, 1956).

Todavia, as origens do trabalho terapêutico com famílias remontam aos estudos psicanalíticos de Freud no início do século XX, o qual apontava a importância das 
relações familiares para o trabalho do psicanalista. O desenvolvimento de diferentes propostas no campo da psicanálise para o trabalho com famílias esteve baseado nas ideias de Melanie Klein, Donald Winnicott, José Bleger, Enrique Pichon-Rivière e do próprio Freud. As correntes francesas e latino-americanas levam o foco para as configurações vinculares dos membros da família, e as perspectivas americanas e inglesas estão mais interessadas no funcionamento inconsciente partilhado pelos membros da família (Gomes \& Levy, 2009).

Outras importantes influências para o desenvolvimento da TF vieram de diversas áreas do conhecimento, tais como a Psicologia, Antropologia, Sociologia, Biologia, entre outras. Assim, ao lado das propostas psicanalíticas para o atendimento de famílias, foram se constituindo também perspectivas que originaram o campo da terapia familiar sistêmica, que abordaremos a seguir. Estas duas perspectivas - sistêmica e psicanalítica - em geral, são referidas como discordantes em seus pressupostos teóricos e epistemológicos, e as primeiras propostas no campo sistêmico enfatizavam as inovações e diferenças em relação às propostas psicanalíticas, buscando uma diferenciação do foco individualista predominante.

Todavia, a despeito destas diferenças aparentemente inconciliáveis, aproximações e articulações entre estes dois enfoques fizeram parte da produção teórica e da prática clínica. Por exemplo, Nathan Ackerman, psiquiatra norteamericano que fundou o Instituto Ackerman em Nova York e é um dos precursores da TF nos EUA, integrava em suas propostas e sua prática clínica pressupostos da psicanálise e das teorias sistêmicas. No contexto brasileiro, Féres-Carneiro (1996) também oferece uma proposta de articulação entre estas duas perspectivas, destacando aspectos teóricos de cada uma que podem ser utilizados pelo terapeuta de família. Vemos, assim, que a busca por aproximações e a construção de práticas que integram diferentes enfoques está presente no campo desde o início da terapia familiar sistêmica.

A origem da terapia familiar sistêmica remonta à publicação, em 1948, do livro Cibernética: ou controle e comunicação no animal e na máquina, do matemático Norbert Wiener (1948/1970), o qual propôs uma teoria acerca da comunicação e do controle que poderia ser aplicada a diferentes sistemas, tanto máquinas quanto seres humanos. A cibernética, como teoria, oferece uma proposta sistêmica ao tirar a atenção dos elementos de um complexo para focar nas relações entre tais elementos. Suas ideias foram, assim, incorporadas ao estudo das relações humanas, trazendo 
critérios que buscavam se diferenciar da tradição cartesiana dominante. Conceitos tais como informação, feedback e organização passaram a estruturar a construção de conhecimentos sobre as relações e a comunicação humana. Estudiosos de diferentes áreas e em diversos países começaram a agrupar-se e construir propostas explicativas para o trabalho com indivíduos e famílias, dando origem ao campo da $\mathrm{TF}^{2}$. O referido trabalho de Bateson e seus colaboradores em Palo Alto (Bateson et al, 1956) foi a primeira publicação que articula tais pressupostos com a prática clínica, marcando de forma definitiva a utilização destas ideias no trabalho com famílias.

Em 1968, Ludwig von Bertalanffy, biológo austríaco, publica o livro Teoria Geral dos Sistemas: fundamentos, desenvolvimentos e aplicações, o qual propõe "a formulação de princípios válidos para os 'sistemas' em geral, qualquer que seja a natureza dos elementos que os compõem e as relações ou 'forças' existentes entre eles” (Bertalanffy, 1968/2008, p. 62). Baseado em princípios interdisciplinares, o autor propõe que sua teoria seja aplicada a sistemas de natureza diferentes, dentre eles, as relações humanas. Ainda que pareça semelhante às ideias da cibernética para o campo da ciência, estas teorias não podem ser tidas como equivalentes (Bertalanffy, 2008; Rapizo, 2002; Vasconcellos, 2009). Vasconcellos (2009) sintetiza as principais diferenças entre a proposta de Wiener e Bertalanffy afirmando que a primeira possui uma tendência mecanicista, enquanto a segunda parte de uma visão organicista na compreensão e aplicação de suas ideias.

De qualquer modo, ambas ofereceram importantes contribuições para a construção inicial do campo da TF, inspirando diversos estudos e propostas. Os terapeutas e teóricos passam a considerar a família como um sistema, deslocando o foco dos indivíduos para a relação entre eles. Os sintomas passam a ser entendidos como resultado da interação entre os membros da família, e o processo de comunicação adquire importância capital na forma como os terapeutas entendem o processo interacional da família e constroem suas intervenções. O lugar do terapeuta, assim, é marcado pela preocupação em utilizar seus recursos técnicos para operar sobre os padrões comunicacionais da família, em direção à mudança.

Dada a importância da cibernética na criação e desenvolvimento destas ideias, os primeiros períodos da história da TF são descritos a partir dos termos "cibernética

\footnotetext{
${ }^{2}$ Maria José Esteves de Vasconcellos, em sua obra Pensamento Sistêmico: o Novo Paradigma da Ciência (2002), oferece uma descrição detalhada dos diversos encontros e congressos que foram organizados nesta época e fomentaram a construção das propostas e teorias pioneiras no campo.
} 
de primeira ordem" e "cibernética de segunda ordem", cada qual com suas contribuições específicas.

A cibernética de primeira ordem abarca as primeiras décadas do desenvolvimento da $\mathrm{TF}$, entre os anos 50 e 70. A principal característica da prática clínica é a exploração do padrão relacional e comunicacional da família, identificando regras de funcionamento do grupo como um todo. O conceito de homeostase é trazido da biologia e incorporado à compreensão dos sistemas familiares, dizendo respeito ao modo de funcionamento da família e implicando que a finalidade de suas interações é a manutenção do equilíbrio através de uma resistência à mudanças em sua organização. Assim, o sintoma de um dos membros ativa respostas em toda a família em busca de atenuar seus impactos e manter a estabilidade do funcionamento familiar. A partir deste entendimento, o foco das intervenções do terapeuta é induzir uma crise na família, a qual rompe esta homeostase e proporciona que o sistema atinja novos níveis de funcionamento, que prescindem do sintoma (Rapizo, 2002).

A prática do terapeuta é marcada por uma postura diretiva e interventiva, hierarquicamente orientada uma vez que o profissional vê-se detendo o controle do processo terapêutico. Considerado um expert e estrategista, seu objetivo é definir os problemas e as soluções, buscando a eliminação ou redução dos sintomas. Os instrumentos técnicos utilizados são as diretivas terapêuticas - um conjunto de tarefas e instruções que a família deve seguir (Costa, 2010; Hoffman, 1998; Rapizo, 2002; Strong, 2002).

As principais correntes criadas neste período são as terapias estratégicas, e a proposta de Jay Haley (Haley, 1976) é uma grande influência nas práticas orientadas por estes pressupostos. Os trabalhos de Bateson a equipe de Palo Alto também foram centrais para estas propostas, assim como a teoria da comunicação desenvolvida por Paul Watzlawick e seus colaboradores (Watzlawick, Beavin \& Jackson, 1973), focada na dimensão pragmática da comunicação. Salvador Minuchin e sua proposta de uma terapia estrutural também ofereceu ideias importantes para a época e que continuaram a se desenvolver nas décadas seguintes, acompanhando mudanças teóricas e epistemológicas no campo (Minuchin, 1982; Minuchin, Lee \& Simon, 2008). O Grupo de Milão também desenvolveu práticas embasadas nestes pressupostos. Inicialmente, era composto por Mara Selvini-Palazzoli, Giuliana Prata, Luigi Boscolo e Gianfranco Cecchin, quatro terapeutas comprometidos em aplicar rigorosamente as ideias de Bateson na prática clínica em TF. Ao longo da década de 
70, as práticas do Grupo de Milão tinham um foco na comunicação e nos jogos da família, envolviam a prescrição de rituais e possuíam sessões estruturadas em cinco partes, marcadas por diretividade e estrategicamente orientadas (Palazzoli, Prata, Boscolo \& Cecchin, 1980).

O aspecto marcante da cibernética de primeira ordem é o entendimento do terapeuta como separado do sistema familiar, isto é, atuando a partir de uma postura externa que lhe permite agir com neutralidade e objetividade, tanto na relação com a família, como na criação das intervenções e estratégias terapêuticas. Assim, o processo de construção de conhecimentos do terapeuta é visto sob o prisma da objetividade, em que o sistema terapêutico (família) e o sistema observador (terapeuta) são vistos de forma separada, distinta.

Dallos e Urry (1999) afirmam que a transição entre a cibernética de primeira e segunda ordem pode ser entendida de três maneiras diferentes: como um rompimento radical nos pressupostos fundantes da prática, resultado da crítica à ideia de sistema; como um movimento gradual que levou em consideração princípios que faziam parte das obras e propostas desde as primeiras décadas da TF, mas que foram ignorados devido à ânsia pela aplicação das ideias sistêmicas; ou como tendo sido uma mudança que ocorreu paralelamente à transformações no campo das ciências sociais ao longo da década de 70, que buscavam incluir as ideias construtivistas e teciam diversas críticas ao foco mecanicista das propostas sistêmicas.

A cibernética de segunda ordem baseia-se em ideias e pressupostos que marcaram o campo a partir de meados da década 70, até o início da década de 90. As propostas da época foram principalmente influenciadas pelas ideias do químico Ilya Prigogine, dos biólogos Humberto Maturana e Francisco Varela, do físico Heinz von Foerster e do filósofo Ernst von Glasersfled. Além destes, Gregory Bateson continuou o desenvolvimento de suas ideias, mantendo sua influência para a construção de propostas teóricas e epistemológicas.

O marco da cibernética de segunda ordem é o que Vasconcellos (2009) descreve como o giro de autorreferência da cibernética, em que esta toma a si mesma como objeto de estudo e, segundo Rapizo (2002), o conceito básico que proporciona esta mudança é a ideia de clausura operacional. Este termo faz parte da proposta de Maturana e Varela (1995), cujo entendimento da construção do conhecimento como um fenômeno biológico e social inovou concepções acerca das relações humanas. 
Para estes autores, o fenômeno do conhecer está atrelado à nossa estrutura como seres vivos, não podendo ser determinado pelas condições e elementos externos à nós, mas apenas pela estrutura e organização do sujeito. Este modo de funcionamento define uma clausura operacional, ou seja, implica que não há possibilidade de estabelecermos relações instrutivas com o meio em que vivemos. Assim, os conhecimentos que cada pessoa constrói estão atrelados à sua própria estrutura, e não às características e elementos da realidade externa.

Esta proposta traz como implicação a impossibilidade de construção de conhecimentos objetivos sobre o mundo. A realidade, assim, é considerada uma construção intersubjetiva e está pautada na existência de diferentes domínios explicativos, ou seja, domínios linguísticos compartilhados que organizam a vida das pessoas que partilham das mesmas premissas (Maturana, 2002).

Uma vez que a cibernética passa a ocupar-se dos processos de construção do conhecimento, torna-se uma proposta epistemológica para o campo da TF, e por isso é definida com o termo cibernética de segunda ordem. Ao voltar seu interesse principal para o fenômeno do conhecer, o sujeito é incluído nos conhecimentos que constrói sobre o mundo e a noção de realidade é, assim, colocada entre parênteses.

Os terapeutas são incluídos nas observações que constroem acerca das famílias, e o sistema terapêutico passa a incluir também o profissional. Nesta mudança, o conceito de sistema observante criado por Von Foerster (1991) tem um papel fundamental ao propor que o observador (terapeuta) "se observe observando" os sistemas que emergem nas distinções que faz do mundo. Assim, a passagem para uma cibernética de segunda ordem marca a importância da autorreferência do terapeuta, considerado parte de suas observações, o que oferece uma mudança na forma como é compreendida e estabelecida a relação terapêutica e propicia a construção de uma ética diferente para as práticas assim orientadas (Costa, 2010; Rapizo, 2002). Nas palavras de Guimarães e Costa (2003, p. 165), “a inclusão do observador é a humanização do conhecimento, um conhecimento produzido e produto da humanidade”.

A partir das ideias de Maturana e Varela (1995), os sistemas passam a ser considerados auto-organizadores, ou seja, não determinados pelo meio externo mas sim por sua própria estrutura. As propostas de Prigogine oferecem ainda novas formas de compreensão dos sistemas, que agora são vistos como unidades complexas que funcionam distantes do equilíbrio, instáveis e que atuam transformando ordem 
em desordem, selecionando elementos do meio externo que lhes podem ser úteis para alcançar novos patamares de funcionamento (Rapizo, 2002).

Sob estes novos pressupostos, a prática clínica é organizada pela ideia de paradigma familiar, definido como os sentidos e práticas compartilhadas que organizam e dão sentido à vida familiar e às experiências de seus membros. $\mathrm{O}$ terapeuta inclui a si mesmo no processo de construção da mudança, assim como vêse responsável pelos sentidos que são construídos, perpetuados ou transformados no processo terapêutico. A reflexividade torna-se parâmetro importante da prática do terapeuta, tanto para pensar e estruturar suas próprias ações, quanto na relação com os clientes, pois suas perguntas e intervenções buscam convidar a família a construir conhecimentos sobre si mesma e oferecer espaços para os membros exercerem a reflexividade acerca de seus próprios pressupostos e visões de mundo.

Estas ideias têm um papel fundamental na consolidação do construtivismo como pressuposto epistemológico do campo da TF, e a linguagem assume um lugar proeminente nas teorias e práticas. A importância das narrativas, história, cultura, diálogo e processos de co-construção das mudanças e dos significados dão forma a um movimento que busca diferenciar-se do tecnicismo e mecanicismo que marcaram o uso das ideias sistêmicas na cibernética de primeira ordem (Grandesso, 2006).

A segunda fase do já referido Grupo de Milão ilustra práticas baseadas na cibernética de segunda ordem. Na década de 80, os quatro terapeutas passaram a seguir caminhos diferentes no desenvolvimento de suas práticas. Mara SelviniPalazoli e Giuliana Prata continuaram trabalhando juntas a partir do foco na comunicação, nos jogos da família e no uso de intervenções estratégicas. Por sua vez, Luigi Boscolo e Gianfranco Cecchin foram influenciados pelas propostas da cibernética de segunda ordem e propuseram mudanças importantes suas propostas por exemplo, a ressignificação dos conceitos-chave de hipotetização, circularidade e neutralidade (Cecchin, 1989), fundamentais para o Grupo de Milão na década anterior.

Em termos das continuidades entre a cibernética de primeira e segunda ordem, Dallos e Urry (1999) destacam que, em ambas, a observação de padrões relacionais é estruturante da prática terapêutica. Contudo, enquanto na cibernética de primeira ordem a descrição dos padrões está focada em mecanismos de retroalimentação e troca de informações, na cibernética de segunda ordem o foco recai sobre como tais 
padrões são modelados pelos significados, crenças e histórias de cada membro em particular e da família como um todo.

No período até a década de 70, as propostas da TF chegaram ao Brasil por meio de profissionais que buscaram especialização em outros países ou com profissionais estrangeiros. As publicações em língua portuguesa eram raras - em geral, os profissionais liam os textos em língua inglesa ou em espanhol - e ainda não haviam cursos de formação em TF no país. A aprovação da Lei do Divórcio, em 1977, e incentivos ligados à Igreja Católica influenciaram a criação de centros de atendimento a famílias e casais (Aun, 2005/2012; Macedo, 2008).

Desse modo, entre 1976 e 1987 foram criados os primeiros cursos de formação e grupos de estudo sobre terapia familiar no Brasil. Na década de 80, surgiram as duas primeiras revistas de publicação específica sobre TF: "Família. Temas de Terapia Familiar e Ciências Sociais", em Fortaleza, e "Nova Perspectiva Sistêmica", no Rio de Janeiro (Aun, 2012).

A partir da década de 1990, a TF foi fortemente influenciada por propostas afinadas com a pós-modernidade e o movimento construcionista social em ciência. Para apresentar estas influências, primeiramente definiremos, em linhas gerais, estes movimentos no contexto científico em que surgiram e, no item seguinte deste capítulo, destacaremos as principais implicações destas ideias para a temática desta pesquisa - a integração de teorias e técnicas na prática clínica.

No âmbito científico, o tema da pós-modernidade é delineado a partir de múltiplos pontos de vista. Constitui-se em um campo de estudos híbrido, composto por diferentes autores e perspectivas, afastando-nos da possibilidade de estabelecer uma definição abrangente e consensual. Neste estudo, circunscrevemos nossas considerações a partir de algumas correntes de discussão no campo da Psicologia e da TF que se colocam criticamente em relação às noções modernas de verdade e realidade, centrais para a prática científica (Kvale, 1992; Moscheta, 2014).

A pós-modernidade refere-se a um movimento crítico em relação à possibilidade de construção de conhecimentos objetivos sobre a realidade, um pressuposto da ciência moderna segundo o qual podemos ter acesso à realidade externa de forma neutra e objetiva (Kvale, 1992). Contrariamente, o movimento pósmoderno concebe a construção de conhecimento como um processo que ocorre por meio de práticas de linguagem, e está atrelado aos contextos culturais e discursos circulantes no meio social (Flaskas, 2010). É desafiada, assim, a noção moderna de 
que através de conhecimentos objetivos chegamos a descrições verdadeiras dos fenômenos e objetos. Sob o ponto de vista pós-moderno, o que definimos como sendo a "verdade" passa a ser considerado uma forma particular de produzir sentidos sobre o mundo.

Além das influências do movimento pós-moderno, o campo da TF foi influenciado pelas ideias do movimento construcionista social em ciência. O construcionismo social é uma forma de elaboração das críticas pós-modernas e teve especial influência no campo da TF. Definido como um movimento em ciência, o construcionismo descreve a construção da realidade por meio das práticas de linguagem, levando o foco para os processos de negociação e coordenação entre as pessoas, através dos quais o sentido de realidade emerge (K. Gergen, 1985).

As propostas construcionistas sociais trazem um novo giro epistemológico para o campo da TF. Hoffman (1998) descreve este movimento como sendo uma "virada linguística”, cuja epistemologia está pautada na construção social do conhecimento, em que conhecimento e linguagem são considerados produtos de trocas sociais, inviabilizando quaisquer descrições que definam "o que as coisas são" de forma independente do tempo e lugar em que são feitas estas afirmações (K. Gergen, 1985).

Vemos, assim, que a cibernética de segunda ordem, com sua base construtivista, e o construcionismo social partilham algumas bases comuns. Ambos consideram que não existe uma realidade externa que pode ser conhecida com exatidão objetiva (Hoffman, 1998). Além disso, partilham a ênfase no sentido como central para as experiências e dinâmicas familiares. Contudo, as propostas construtivistas consideram o processo de produção de sentidos a partir de uma perspectiva individual, enquanto o construcionismo social compreende o sentido como produto das relações, do que acontece entre as pessoas (Castelló, 2016; Dallos \& Urry, 1999).

Rasera e Japur (2004) descrevem ênfases que as ideias construcionistas trazem para a prática clínica, são elas: foco nos sentidos que orientam a vida e o cotidiano das pessoas; o entendimento da terapia como um processo de co-construção, no qual o terapeuta busca abandonar a postura de especialista e adotar uma forma mais colaborativa de relacionar-se com os clientes; o foco nas relações entre as pessoas e nos sentidos aí construídos; a sensibilidade aos valores que permeiam a relação terapêutica e influenciam a construção de sentidos neste contexto; a ênfase polivocal, que reconhece a multiplicidade de formas de descrição de um problema e explicita a existência de múltiplos selves que nos constituem nas diferentes relações que 
estabelecemos; a preocupação com uma dimensão pragmática que envolve a terapia, evidenciada na busca pela utilização e ampliação dos discursos desenvolvidos no contexto terapêutico para diversos outros contextos; e, por fim, o foco nas potencialidades ou recursos dos indivíduos e relações na construção de ações futuras.

Algumas propostas ilustram o uso destas ideias no contexto da prática. Sheila McNamee e Kenneth Gergen, dois teóricos norte-americanos importantes no campo das propostas construcionistas, organizaram um livro que reúne autores, terapeutas e profissionais a partir de seu enfoque em premissas partilhadas pelo construcionismo social (McNamee \& K. Gergen, 1992), publicado em diversos idiomas, inclusive em português (McNamee \& Gergen, 1998). Ambos continuam contribuindo para o desenvolvimento de descrições e articulações teórico-práticas que influenciam a TF, tanto no âmbito internacional como no Brasil.

Harlene Anderson e Harold Goolishian também desenvolveram propostas relevantes para a prática clínica. No final da década de 80 e início da década de 90, os autores propuseram uma passagem do foco nos sistemas para o foco nos processos dialógicos da conversa terapêutica e a ênfase em uma postura de não-saber por parte do terapeuta, o qual atua como um arquiteto do diálogo enquanto os clientes são considerados especialistas em suas próprias vidas (Anderson \& Goolishian, 1988, 1992). Após o falecimento de Harold Goolishian, em 1991, Harlene Anderson manteve os desenvolvimentos de sua obra, solidificando a proposta da terapia colaborativa no campo da prática clínica (Anderson, 1997; Anderson \& Gehart, 2006).

Tom Andersen, psiquiatra norueguês, propôs os processos reflexivos como uma forma de compreender e atuar em terapia, que está baseada na ideia de uma partilha de significados que buscam gerar novas informações para o sistema terapêutico, as quais visam, ao mesmo tempo, respeitar a integridade dos participantes e trazer elementos inusitados que produzam mudanças. A equipe reflexiva, um método de construção de conversas baseado na alternância entre as posições de fala e escuta, transformou substancialmente alguns pressupostos da prática clínica voltados para a hierarquia e poder na relação entre terapeutas e clientes (Andersen, 2002).

Os terapeutas Michael White e David Epston, da Austrália e Nova Zelândia, respectivamente, delinearam a proposta da terapia narrativa no campo da $\mathrm{TF}$, que está amplamente difundida em diversos países do mundo. Propondo o foco nas construções narrativas e na possibilidade de ressignificação e empoderamento a 
partir do questionamento de discursos dominantes presentes em nossas vidas, estes autores aproximam-se de diversas premissas e sensibilidades construcionistas e pósmodernas (White \& Epston, 1980; White, 2012).

John Shotter, psicólogo britânico, foi um eminente teórico que trouxe contribuições fundamentais para o desenvolvimento das ideias construcionistas sociais. Aproximando seu trabalho da prática de diferentes profissionais e terapeutas familiares, suas ideias são uma grande influência para diversos terapeutas e teóricos que articulam as ideias construcionistas à prática em TF (Shotter, 2008, 2011).

Na década de 1990, estas ideias tiveram contato com o campo da TF no Brasil. Diversos eventos brasileiros contaram com a participação de autores e terapeutas familiares estrangeiros influenciados pelas ideias pós-modernas e pelo construcionismo social. Nesta década, o movimento da TF solidificou-se no país devido à fundação, em 1994, da Associação Brasileira de Terapia Familiar (ABRATEF) e a subsequente criação das Associações Regionais em diferentes estados do país.

Flaskas (2011) afirma que as perspectivas contemporâneas em TF possuem um "território compartilhado" composto pela ênfase na linguagem e na construção do sentido como um fenômeno atrelado às condições históricas, sociais e culturais, território este constituído pelas ideias pós-modernas e suas influências na TF. O autor ressalta, ainda, o grande potencial que elas oferecem para novas elaborações no campo da prática clínica.

A presente narrativa sobre o desenvolvimento histórico que marca a produção de conhecimento na área buscou, como afirmamos anteriormente, trazer tanto as rupturas como as continuidades entre as principais bases epistemológicas dos diferentes enfoques presentes no campo da TF. Tecemos, agora, algumas considerações acerca das influências que a pós-modernidade e o construcionismo social trouxeram à integração de diferentes recursos teóricos e técnicos na prática clínica.

\subsection{A relação do terapeuta com técnicas e modelos teóricos}

Tanto a pós-modernidade quanto o construcionismo social trouxeram propostas ao campo científico que, quando em contato com a TF ocasionaram mudanças na 
forma como as técnicas e modelos teóricos passaram a ser compreendidos e utilizados na prática clínica. Além destes dois movimentos, as pesquisas sobre os fatores comuns da terapia também diminuíram a competitividade entre enfoques no campo da TF. Nesta seção, abordamos estas questões, articulando-as com o entendimento da integração na prática clínica como alternativa para a necessidade de filiação a um único modelo.

O entendimento pós-moderno acerca do processo de produção de conhecimento, que é definido a partir de suas raízes nos contextos sociais e discursos que circulam no meio cultural, arrefeceu a busca dos teóricos e profissionais pelo modelo teórico ideal que, supostamente, melhor descreveria o processo terapêutico (Flaskas, 2010). Esta perspectiva abriu espaço para debates e reflexões que romperam com tradições na $\mathrm{TF}$. Isto porque, como afirmamos anteriormente, a TF tem se constituído, desde sua origem, como um campo em que coexistem diferentes teorias e epistemologias, e a competitividade entre escolas e abordagens implica que modelos teóricos devam ser considerados descrições correspondentes à realidade. Tal competitividade foi arrefecida pela mudança na compreensão dos processos de construção do conhecimento apontada pela pós-modernidade (Flaskas, 2010).

A ênfase pós-moderna na multiplicidade também influenciou sobremaneira a prática em TF, uma vez que o questionamento de verdades estruturantes da vida em sociedade transformou profundamente a organização social e familiar (Macedo, 2008). A crítica ao modelo ideal de família colocou em xeque a figura da família patriarcal, burguesa, heterossexual e composta por pai, mãe e filhos. Criou-se espaço para configurações familiares alternativas, marcadas por formas de organização diferentes daquelas vividas por gerações anteriores. Esta mudança exigiu que a prática em TF se transformasse, e o campo abriu-se para modelos explicativos que dessem conta destas novas formas de ser família. Assim, utilizar múltiplos conhecimentos adquiriu o significado de uma prática que responde às novas demandas da vida em sociedade (Smith \& Southern, 2005).

A utilização das propostas construcionistas sociais na TF também trouxe mudanças relevantes. A partir da sensibilidade construcionista, os modelos teóricos deixaram de ser vistos como uma representação do que o processo terapêutico "realmente é", para serem entendidos como formas particulares de produção de sentidos sobre a terapia (Flaskas, 2010). Assim, teorias podem ser consideradas opções discursivas, ou seja, recursos conversacionais utilizados pelo terapeuta para 
construir diálogos generativos com os clientes, em busca da transformação desejada (McNamee, 2004a). Esta orientação deixa para trás a preocupação em definir qual teoria é "certa" ou "a melhor" para abordar determinada demanda dos clientes, definindo-se mais pela busca em construir diálogos que sejam responsivos à singularidade de cada atendimento terapêutico. Além disso, é uma orientação do terapeuta que o aproxima da compreensão dos modelos teóricos como metáforas, ou seja, construções discursivas sobre o mundo, não sendo consideradas válidas, corretas e eficazes em si mesmas (Paula-Ravagnani, Guanaes-Lorenzi \& Rasera, 2017).

Além do movimento pós-moderno e do construcionismo social, as pesquisas sobre os fatores comuns da terapia também proporcionaram mudanças na forma como os terapeutas relacionam-se com aportes teóricos na prática clínica e contribuiu para a diminuição da competitividade entre modelos.

As pesquisas sobre os fatores comuns da terapia fazem parte de um movimento no campo da psicoterapia que teve seu início na década de 1930 e, a partir da década de 80 , as crescentes influências da pós-modernidade deram destaque a estas pesquisas (Flaskas, 2010; Lebow, 2014; Smith \& Southern, 2005). Os fatores comuns em terapia são definidos como variáveis que contribuem para a mudança terapêutica e que não estão relacionados a uma abordagem ou modelo teórico específico. Esta proposta enfatiza que há fatores e mecanismos de transformação que são comuns a diferentes modalidades terapêuticas eficazes (Davis, Lebow \& Sprenkle, 2012; Sprenkle \& Blow, 2004).

No campo da psicoterapia em geral, os fatores comuns são compostos por diferentes dimensões do tratamento: cliente; terapeuta; relação terapêutica; crença do terapeuta no modelo que segue; expectativa e esperança do cliente em relação ao tratamento (efeito placebo); e mudanças nas ações, perspectivas e vivências emocionais. A modalidade da TF possui fatores comuns específicos: descrição das dificuldades em termos relacionais; rompimento de padrões relacionais disfuncionais; expansão do sistema terapêutico para incluir novos membros da família; e aliança terapêutica expandida (Davis, Lebow \& Sprenkle, 2012; Sprenkle \& Blow, 2004).

As pesquisas sobre os fatores comuns atenuaram a competitividade entre modelos teóricos ao propor que a eficácia terapêutica não está ligada ao modelo em si. Todavia, autores que defendem posturas moderadas em relação aos fatores 
comuns (Davis, Lebow \& Sprenkle, 2012) não descartam o uso de modelos teóricos, sugerindo que o foco do terapeuta se volte para as formas pelas quais teorias e práticas podem promover os fatores de sucesso da terapia. De qualquer maneira, estas pesquisas fortalecem debates acerca do entendimento dos modelos teóricos como descrições possíveis da realidade (Flaskas, 2010).

Vemos, assim, que o construcionismo social, as ideias pós-modernas e as pesquisas sobre os fatores comuns da terapia não só trouxeram mudanças à forma como o terapeuta pode se relacionar com técnicas e modelos teóricos da TF, como também favorecem a construção de práticas clínicas que integram diferentes contribuições. Na próxima seção, abordaremos mais especificamente a questão da integração na prática clínica.

\subsection{A integração na prática clínica em terapia familiar}

Nesta seção, abordaremos a questão da integração na prática articulando-a com definições presentes na literatura científica da área para, em seguida, situar como abordaremos esta temática na pesquisa em relação ao amplo campo de estudos que ela delineia na TF. Por fim, apresentamos as perguntas da pesquisa e a tese que sustentamos para sua realização.

Imber-Black (2014) afirma que o atual desenvolvimento de modelos e propostas de integração de práticas tornou-se uma alternativa para a necessidade de aliança "pura" a um modelo, trazendo formas de pensar que lançam mão de diferentes recursos e exigem flexibilidade, por parte do profissional, para outras formas de compreender e atuar em terapia. A autora destaca que estas propostas de práticas baseadas na integração foram surgindo à medida que as novas gerações tiveram a "encantadora audácia” (p. 374) de desafiar as tradições e criar o novo quando os modelos pareceram insuficientes para lidar com as demandas dos contextos de vida atuais.

Assumindo uma postura diferente em relação ao que seria uma novidade relativa à integração na prática clínica, Flaskas (2010) sublinha o fato das propostas de integração de diferentes recursos na prática clínica terem ganhado mais força e ênfase nos últimos trinta anos, ainda que este aspecto sempre tenha estado presente na prática clínica cotidiana. 
Neste sentido, Flaskas (2005) considera que a prática clínica cotidiana, com os desafios que apresenta, envolve o uso de diferentes ideias e habilidades por parte do terapeuta. $\mathrm{O}$ autor entende como sendo uma escolha do terapeuta a descrição de sua própria prática a partir de um único modelo, enquanto a prática necessariamente incluiria o uso de outros recursos por parte do profissional. O estudo de Solomonov, Kuprian, Zilcha-Mano, Gorman e Basber (2016) reitera estas considerações ao concluir que os profissionais utilizam níveis de integração mais altos do que declaram explicitamente. Para os autores, é possível que os tratamentos difiram entre si mais na teoria do que na prática, uma vez que cada teoria enfatiza o que é único em sua proposta, mais do que os elementos que utilizam e são provenientes de outras inspirações, tanto técnicas quanto teóricas.

Lebow (2014), analisando o desenvolvimento do campo da TF, considera que ainda há uma divisão entre aqueles terapeutas que propõem o uso de apenas um modelo teórico e prático no atendimento de famílias, e aqueles que integram diferentes modelos em seu trabalho. Todavia, o autor não situa estes posicionamentos em forma de uma polaridade, em que os terapeutas assumem um ou outro lado. Diferentemente, o autor utiliza o termo "spectrum" para referir-se ao continuum que abarca estas duas posições, levando-nos a entender que existem diversas nuances que caracterizam terapeutas cuja prática aloca-se em algum ponto entre estes dois polos.

Vemos, assim, que a literatura oferece diferentes descrições acerca de quando e como a integração se faz presente na prática clínica cotidiana. Contudo, diferentes autores e comentadores do campo da $\mathrm{TF}$ indicam a existência de um recente movimento que expande e refina a integração de práticas na atualidade, mesmo que algum nível de integração sempre tenha feito parte da prática clínica cotidiana (Dickerson, 2010, 2014; Flaskas, 2005, 2010; Lebow, 1988, 2014; Oddli \& McLeod, 2017; Pinsof, 1992; Prati \& Koller, 2012; Smith \& Southern, 2005; Snyder \& Balderrama-Durbin, 2012; Solomonov et al, 2016). Desse modo, a integração como um movimento e um fenômeno no campo da TF passou a receber mais atenção, tanto acadêmica quanto clinicamente.

Em língua portuguesa, a palavra integração é definida como a "incorporação de um elemento num conjunto" (Houaiss, 2009). Pensada no contexto da prática em $\mathrm{TF}$, tal acepção nos convida à ideia de incorporação de elementos diversos em um 
todo que se apresenta coeso. Parece remeter, assim, à ideia de unicidade - um modelo singular composto por diferentes elementos, unidos em um todo coerente.

$\mathrm{Na}$ literatura, esta acepção se faz presente em algumas definições. Lebow (2014) afirma que as perspectivas integrativas caracterizam-se pela fusão de modelos em um novo enquadre que, em um metanível, é capaz de explicar o encadeamento das ideias e técnicas. Pinsof (1992) descreve esta como sendo uma característica "holística", uma vez que o resultado da combinação é mais do que a soma das partes.

Lebow (2014) diferencia a integração do ecletismo afirmando que este último caracteriza-se pela utilização de diferentes técnicas e conceitos, sem que haja uma inteligibilidade que identifique porquê tais elementos foram conectados. Para Pinsof (1992), o ecletismo também caracteriza-se pelo foco no uso concomitante de diferentes técnicas, mas o elemento principal é seu foco empírico, organizado em torno "daquilo que funciona" para determinado processo terapêutico. Para o autor, nas formas ecléticas menos sofisticadas, o que prevalece é a intuição do terapeuta, o qual utiliza qualquer coisa que parece servir para o manejo da situação que se apresenta, sem que seja dada muita atenção para a consistência clínica e teórica. Nas formas ecléticas mais sofisticadas, o princípio organizador tende a ser os dados empíricos que indicam qual teoria ou técnica é mais eficaz para o manejo de um problema específico.

Smith e Southern (2005), em uma revisão de literatura sobre perspectivas integrativas, apresentam autores que partilham da definição da integração a partir da combinação de conceitos teóricos de forma que, geralmente, resulta na criação de uma nova teoria ou abordagem. Os autores apresentam sete enquadres integrativos que, até aquele momento, estavam presentes no campo da TF: Metaenquadres; Terapia Integrativa Centrada no Problema; Terapia de Casal Integrativa; Abordagem Multimodal; Modelo Integrativo-Contextual; Modelo Biopsicossocial; Terapia Familiar Integrativa3.

Neste estudo, não estamos afinadas com a ideia de que a integração pressupõe a construção de "um todo integrado", que pode ser descrito como uma nova abordagem ou teoria da prática clínica em TF. Por meio da expressão integração na prática clínica de terapeutas familiares, contida no título da pesquisa, nos referimos

3 Tradução livre dos originais, em língua inglesa: Metaframeworks; Integrative Problem-Centered Therapy; Integrative Couple Therapy; Multimodal Approach; Integrative-Contextual Model; Biopsychosocial Model; Integrative Family Therapy Model. 
à possibilidade do terapeuta utilizar diferentes recursos e inspirações em suas ações, no contexto do encontro terapêutico.

Consideramos que o encontro entre terapeuta e clientes visa a construção de um contexto em que pretende-se alcançar a transformação de situações sentidas como geradoras de sofrimento. Nesta relação, as ações do terapeuta são embasadas em múltiplos recursos, provenientes tanto do conhecimento tácito do profissional, quanto de elementos de cada processo terapêutico em particular. Ou seja, aquilo que o terapeuta faz na relação com os clientes está relacionado com: aspectos daquelas relações específicas, o problema apresentado à terapia, as experiências prévias e o self do terapeuta - articulado tanto em torno de vivências profissionais como também pessoais e inspirações teóricas.

A nosso ver, esta inspiração do profissional, em algum grau, integra conceitos teóricos, técnicas aprendidas, conhecimentos advindos de experiências anteriores. Estes fatores constituem-se em recursos corporificados que inspiram as ações dos terapeutas no encontro com os clientes.

Em nosso estudo, ao investigarmos as ações dos terapeutas, demos forma a um contexto de construção de justificativas para o que foi feito. Buscamos construir, com os participantes, explicações a posteriori sobre suas ações, visando descrever (e, possivelmente, construir) os critérios utilizados para agirem de determinadas maneiras no encontro terapêutico.

Desse modo, ao abordar a prática clínica de terapeutas familiares sob o ponto de vista da integração, afastamo-nos da ideia de unicidade para nos aproximar da multiplicidade, diversidade e caos que podem ser originados quando tentamos, em uma conversa posterior, construir justificativas para o que foi feito no momento complexo e singular do encontro entre pessoas. Assim, nossa pesquisa aloca-se entre os estudos nacionais e internacionais que buscam investigar como se dá essa integração na prática cotidiana, e para tanto, propomos que seja pesquisado os atendimentos clínicos em seu acontecimento.

A produção científica no contexto brasileiro apresenta estudos corroborando com o fato da integração fazer parte do cotidiano da prática clínica em TF. O estudo de Ponciano e Féres-Carneiro (2005) analisou os Cadernos de Resumos de quatro edições do Congresso Brasileiro de Terapia Familiar (1994, 1996, 1998 e 2002) e indica que os trabalhos apresentados estiveram embasados em teorias diversas, tais como: construtivismo, teoria sistêmica, psicanálise, psicodrama, construcionismo 
social, práticas narrativas, psicologia cognitiva, existencialismo e bioenergética. Hintz e Souza (2009), ao tecerem considerações sobre a diversidade presente na formação de terapeutas familiares brasileiros, indicam estes mesmos enfoques como estando presentes no desenvolvimento de práticas clínicas, a partir de alguma forma de combinação entre eles.

O estudo de Prati e Koller (2012) mapeou a prática de terapeutas familiares em diferentes regiões do Brasil, e indica a utilização de diferentes referenciais teóricos e práticas entre os participantes. Segundo as autoras, esta integração de modelos permite a construção de estilos próprios e do uso da criatividade por parte do terapeuta.

Mais recentemente, nosso estudo acerca do uso das ideias construcionistas sociais na prática clínica indicou que os terapeutas entrevistados endossam discursos de integração de práticas a partir de quatro posicionamentos: conciliatórioconstrucionista, conciliatório-reflexivo, conciliatório-explicativo e eclético (PaulaRavagnani, Guanaes-Lorenzi \& Rasera, 2017). Ainda que tenham algumas diferenças entre si, estes posicionamentos indicam formas de integração na prática que lançam mão, predominantemente, de referenciais sistêmicos e construcionistas sociais na prática clínica com famílias (Paula-Ravagnani, McNamee, Rasera \& GuanaesLorenzi, 2016).

Estes estudos evidenciam que a integração de práticas é uma tendência também no Brasil e ressaltam a relevância de estudos que apontem as especificidades destas integrações no cotidiano da prática clínica.

Assim, considerando nossa pesquisa sob o ponto de vista da produção do conhecimento, vemos que ela (re)apresenta diversas questões importantes para o campo da TF: por que integramos? Como integrar de forma a exercer a criatividade e, ao mesmo tempo, preservar o rigor? O bom é integrar ou ser "purista”?

No âmbito destas tensões, não temos a pretensão de finalizar uma tese que ofereça resposta a cada uma destas perguntas. Diferentemente, nos colocamos em diálogo com estes desafios que há muito acompanham a prática clínica em TF. Sobretudo porque nosso estudo endereça um assunto que, em geral, fica em segundo plano no campo da prática clínica: fomentamos reflexões sobre a pessoa do terapeuta, olhando para como o profissional constrói seus conhecimentos, cria intervenções e perguntas, e descreve critérios para suas escolhas. Esta orientação difere-se do que é costumeiro no campo das conversas e produção do conhecimento 
em TF, as quais abordam discussões sobre o caso atendido, focando em aspectos dos problemas descritos e das famílias que os apresentam.

Propomos um enfoque diferente, pois nosso interesse não é o problema que origina o processo terapêutico, mas sim compreender como o terapeuta faz uso dos conhecimentos teóricos e técnicos que possui, e como constrói conhecimentos sobre suas ações nos casos atendidos. Tal orientação é um fator que indica sua relevância no contexto da TF, constituindo-se em uma das justificativas da pesquisa.

Neste sentido, a pesquisa foi delineada em torno da tese de que a integração de diferentes teorias e técnicas faz parte do cotidiano da prática clínica em terapia familiar. Esta integração desenvolve-se, por um lado, como uma forma de atender demandas complexas com as quais os terapeutas lidam na clínica, e, por outro lado, é uma maneira de utilizar diferentes inspirações e recursos que permeiam a aprendizagem dos terapeutas ao longo da formação e da prática profissional. A partir de nossa inserção do campo-tema (P. Spink, 2003) da TF, consideramos que há ocasiões em que esta integração envolve o uso concomitante de abordagens e perspectivas que partem de epistemologias distintas, gerando tensões em relação ao posicionamento epistemológico do terapeuta na prática clínica.

A elaboração destas reflexões está relacionada com a já citada pesquisa que realizamos anteriormente, na qual entrevistamos terapeutas familiares responsáveis pelo ensino das ideias construcionistas sociais em cursos de formação, buscando investigar a difusão do construcionismo social. Neste estudo, concluímos que a utilização de discursos que endossam algum grau de integração de recursos técnicos e teóricos deu-se a partir da busca pelo enriquecimento da prática clínica (PaulaRavagnani, McNamee, Rasera \& Guanaes-Lorenzi, 2016; Paula-Ravagnani, GuanaesLorenzi \& Rasera, 2017)

A presente pesquisa, assim como outros estudos na área (por exemplo, FéresCarneiro \& Ponciano, 2006; Hickman, Arnkoff, Glass \& Schottenbauer, 2009; Prati \& Koller, 2012), fomentam questões sobre a construção da coerência na prática clínica cotidiana em $\mathrm{TF}$, reacendendo debates sobre como integrar e, ao mesmo tempo, preservar o rigor e a coerência em termos da utilização de diferentes enfoques teóricos e práticos. Este aspecto não foi abordado em nosso estudo anterior, o qual baseou-se em narrativas dos terapeutas familiares sobre sua própria prática, o que entendemos ser distinto do foco nas ações do terapeuta no contexto dos atendimentos clínicos, isto é, no próprio exercício da prática profissional. 
Assim, o objeto de estudo da presente pesquisa é a prática clínica de terapeutas familiares. Nossa pesquisa está atrelada à difusão das ideias construcionistas sociais no Brasil, uma vez que estas não apenas ressignificam os entendimentos dos modelos teóricos, mas também abrem espaço para formas de conciliação de diferentes discursos na prática clínica (Paula-Ravagnani, Guanaes-Lorenzi \& Rasera, 2017).

As perguntas que norteiam a pesquisa são relativas ao cotidiano da prática clínica de terapeutas familiares: como os terapeutas utilizam diferentes recursos teóricos e práticos na atuação clínica? Quais critérios guiam a escolha destes recursos? Existem aspectos do atendimento clínico que influenciam estas escolhas? Quais teorias, práticas e ideias são utilizadas? A que demandas, trazidas por seus clientes, o uso de diferentes práticas respondem? Articulamos estes aspectos em torno da questão central sobre como os terapeutas produzem conhecimentos sobre sua própria prática.

\subsection{Justificativa e objetivos}

O estudo propõe contribuições em âmbitos distintos: para o campo acadêmico, para a interface entre pesquisa e prática em $\mathrm{TF}$ e, possivelmente, para a população que busca a terapia familiar.

No que se refere às contribuições para o contexto acadêmico, as reflexões de Féres-Carneiro e Ponciano (2005) auxiliam na justificativa da relevância de nosso estudo. Em pesquisa sobre a articulação de diferentes enfoques teóricos na prática em TF, as autoras levantam indagações que fomentam o debate no qual nosso estudo se insere: como articular diferentes referenciais teóricos na prática clínica? Para tal articulação, quais critérios seriam utilizados pelo terapeuta? Como desenvolver rigor na articulação de enfoques, para que esta seja realizada de forma clara e efetiva? Estas perguntas ressaltam a importância de investigações sobre a prática do profissional in situ, que oferecem oportunidades de compreender as particularidades que embasam o processo de integração na prática clínica.

Em outras palavras, ao considerarmos a crescente sofisticação da integração de práticas presentes no campo da TF - em diversos países e também no Brasil - vemos que este fenômeno levanta a necessidade de compreendermos os parâmetros dos terapeutas para integrarem diferentes métodos e teorias (Hickman et al, 2009). Neste 
sentido, nosso estudo preenche algumas lacunas e demandas existentes no âmbito acadêmico.

No que se refere às contribuições para o campo gerado na interface entre pesquisa e prática de TF, destacamos alguns aspectos. Gourman (2011) aponta que, embora o número de pesquisas realizadas sobre atendimentos familiares tenha aumentado nas últimas duas décadas, pouco se avançou nas parcerias entre pesquisadores e clínicos, tanto para pensarem questões de pesquisa relevantes para os dois âmbitos, quanto para aumentarem a influência da pesquisa na prática clínica cotidiana. Segundo o autor, geralmente as pesquisas no campo da TF buscam aumentar a efetividade dos trabalhos no âmbito da clínica (Gourman, 2011). Todavia, para que isso seja possível, é preciso que os resultados sejam relevantes para os profissionais. A literatura indica que isso não costuma ocorrer devido à realização de estudo cujas perguntas, objetivos e métodos traduzem um interesse acadêmico mais do que profissional. Além disso, estudos realizados em ambientes controlados e distantes do cotidiano da prática também geram resultados que não dialogam com as necessidades e características da prática (Diniz-Neto \& Féres-Carneiro, 2005; Gourman, 2011; Lebow, 1988; Sexton \& Datchi, 2014).

Sexton e Datchi (2014) ressaltam que a utilidade das pesquisas em TF é relativa à possibilidade de informarem e influenciarem práticas de saúde, políticas públicas e contextos de formação profissional. Para isso, os autores afirmam que a pesquisa deve partir de investigações realizadas em condições viáveis na "vida real". Neste sentido, nosso estudo parte do pressuposto de que a proximidade com as condições da atividade clínica no cotidiano aumenta a possibilidade de nossa pesquisa impactar o campo profissional.

Finalmente, destacamos as possíveis contribuições para a comunidade em geral. A terapia familiar é um recurso utilizado pela população como forma de auxílio para lidar com situações problemáticas. Ao convidar as terapeutas-participantes para o exercício de uma prática crítica e reflexiva, atenta às suas ações e direcionamentos no processo terapêutico, o estudo pode, potencialmente, contribuir para o oferecimento de serviços qualificados no âmbito dos atendimentos às famílias e casais. Assim, constitui-se como uma pesquisa que, ao buscar responder o que é a integração de práticas, também indaga sobre como estes recursos podem oferecer práticas mais potentes e orientadas para o contexto social onde emergem (K. Gergen, 2014). 
Assim, o objetivo geral deste estudo é compreender como terapeutas familiares integram teorias e técnicas como recursos para a prática clínica, em seu cotidiano de atendimentos.

Especificamente, buscamos:

> Descrever os recursos técnicos e teóricos utilizados pelas terapeutas em seus atendimentos;

$>$ Refletir sobre as explicações construídas pelas terapeutas para o uso dos recursos, dando visibilidade às suas justificativas teóricas e articulandoas com a literatura da área. 


\section{Método}

Esta pesquisa é de natureza qualitativa, baseada em propostas da pesquisa-ação colaborativa no campo da ciência, e inspirada pelas ideias construcionistas sociais para a prática de pesquisa em ciências humanas e sociais. Neste capítulo, apresentamos os pressupostos que embasam cada um destes enfoques, em seguida apresentamos o contexto, participantes, os passos para produção e análise dos dados e os aspectos éticos do estudo.

\subsection{Orientação construcionista social}

M. Spink e Menegon (1999/2013) descrevem o método científico como um conjunto de concepções sobre o homem, a natureza e o conhecimento, as quais definem os procedimentos a serem utilizados na construção do conhecimento científico. Desse modo, é relevante apontarmos tais concepções no contexto deste estudo, dando subsídios para a compreensão das escolhas do referencial teóricometodológico e das ferramentas de produção e análise dos dados da pesquisa.

Como afirmamos no capítulo introdutório, o construcionismo social é um movimento em ciência cujas contribuições oferecem norteadores para a prática em distintos contextos - dentre eles, a pesquisa científica. Neste âmbito, o construcionismo coloca-se criticamente em relação às concepções empiristas e positivistas presentes na visão tradicional de ciência, segundo as quais a natureza do mundo pode ser revelada pela observação, que deve ser tão neutra e objetiva quanto possível (Burr, 2003).

Na perspectiva construcionista, a construção do conhecimento é um fenômeno relacional que emerge como resultado da coordenação entre as pessoas no 
transcorrer da vida social, estando, portanto, necessariamente atrelado aos processos históricos e culturais. Por meio das práticas de linguagem, damos sentido ao mundo e organizamos nossas experiências, construindo conhecimentos acerca dos contextos em que vivemos - incluindo, aqui, os sentidos construídos sobre o próprio sujeito (senso de self), sobre as relações em que está inserido e o contexto social em que vive (Guanaes-Lorenzi, Moscheta, Corradi-Webster \& Vilela, 2014).

Tomando a linguagem como aspecto central, o construcionismo social entende que as palavras que utilizamos para descrever o mundo e nossas experiências não guardam uma relação direta com a materialidade daquilo que é descrito. Dito de outro modo, ao considerar a materialidade do mundo, compreendemos que não há uma relação necessária entre o objeto e a palavra que utilizamos para descrevê-lo, e isso implica que o mundo não existe à parte de nossa relação com ele - a realidade emerge a partir do que fazemos juntos, na coordenação de nossas ações na vida social (McNamee, 2010).

Em relação às descrições sobre o mundo, o construcionismo social entende que o sentido está em constante mudança, sofrendo transformações ao longo do tempo, e a linguagem é considerada por seu aspecto performático, uma vez que as diferentes construções de sentido sobre o mundo sustentam formas de ação social (Burr, 2003; McNamee, 2014). Dessa maneira, o construcionismo social desafia as bases objetivas para a construção do conhecimento (K. Gergen, 1985). No campo das ciências humanas e sociais, esta noção implica que as práticas de linguagem não podem mapear, de forma precisa, as experiências dos sujeitos. Os relatos científicos sobre as experiências individuais são compreendidos como uma produção textual imersa em tradições e práticas culturais relativas à produção científica (M. Gergen \& K. Gergen, 2000).

A prática de pesquisa, assim, é considerada uma prática social, uma vez que constitui-se em uma forma particular de produção de sentidos sobre o mundo - tal como a arte, o cinema, a literatura, a religião, o senso comum. Esta concepção legitima estas atividades como formas possíveis de construção de sentidos, reconhecendo que pertencem a domínios de linguagem específicos e circunscritos em torno de certas regras e consensos (M. Spink \& Menegon, 2013).

As concepções abordadas até o momento não implicam na existência de um método construcionista para a prática de pesquisa, pois o construcionismo propõe uma orientação filosófica para a prática científica. Como enfatiza McNamee (2014), a 
orientação construcionista social na pesquisa embasa-se na compreensão de que a ciência é composta por mundos de pesquisa, definidos como diferentes formas de “entender e conduzir pesquisa, incluindo seus propósitos, práticas e convenções de rigor únicos (...) Um mundo de pesquisa é um contexto compreensivo que guia, apoia, financia, conduz e avalia a pesquisa de certas maneiras" (Raboin, Uhlig \& McNamee, 2012, citado por McNamee, 2014, p. 108).

A autora descreve as principais dimensões que compõem os mundos de pesquisa qualitativo e quantitativo, apresentando-os como uma construção conjunta, em que o fazer científico derivado de cada um deles acaba por sustenta-los e reproduzi-los como formas legítimas de investigação científica. Neste contexto, a orientação construcionista social coloca-se em um plano discursivo diferente aos nos convidar a "explorar como somos parte de todos os aspectos do processo de pesquisa" (McNamee, 2014, p. 114). Assim, o foco se desloca para a exploração dos processos de colaboração que marcam a construção do conhecimento, em uma orientação sensível às implicações que tais saberes produzem nas comunidades em que são construídos. Como posicionamento filosófico, a orientação construcionista social é entendida como uma maneira de compreender a produção do conhecimento, e por este motivo favorece a utilização crítica e reflexiva de múltiplas ferramentas metodológicas, entendendo-as como formas de linguagem que constroem diferentes visões do mundo. O método científico é, assim, compreendido como uma forma de produzir inteligibilidades sobre o objeto de estudo, afastando-se da intenção de pesquisa voltada para "descobrir" o mundo e revelar aspectos da realidade (McNamee, 2014).

Tendo exposto a compreensão do construcionismo social sobre as experiências humanas (como situadas em relações sociais e pautadas em práticas de linguagem), sobre a natureza (entendendo que o mundo não existe à parte de nossas descrições), e sobre o conhecimento (como uma produção relacional, situada histórica e culturalmente), acreditamos que a noção de método que fundamenta este trabalho está explícita para o leitor, permitindo-nos abordar, em seguida, a perspectiva da pesquisa-ação para a realização de estudos científicos. 


\subsection{Pesquisa-ação: processos colaborativos na pesquisa}

As propostas da pesquisa-ação em ciência configuram um campo diversificado, com múltiplas perspectivas e abordagens, reunindo teóricos que vão desde as propostas de Kurt Lewin (1965) até aqueles identificados com a pós-modernidade. Não há, portanto, consenso acerca de uma definição única da pesquisa-ação. Neste estudo, nos apoiamos na ideia de pesquisa-ação sob um ponto de vista colaborativo, em que pesquisador e participante, através da ação e do diálogo, engajam-se no processo de produção de sentidos sobre o fenômeno investigado.

A pesquisa-ação é considerada uma orientação em relação à construção do conhecimento em ciência, entendendo que este emerge a partir da prática e requer que o pesquisador trabalhe com os participantes - o que é diferente de realizar uma pesquisa sobre os participantes (Dick \& Greenwood, 2015; Huang, 2010). Baseada em uma visão de mundo participativa, a pesquisa-ação busca criar espaços participativos e democráticos no processo de pesquisa, na tentativa de desenvolver conhecimentos aplicáveis pelos participantes na solução de desafios em suas atividades cotidianas (Reason \& Bradbury, 2008).

Esta forma de pesquisa busca construir um processo generativo entre pesquisador e participantes, no qual todos refletem e constroem conhecimentos em conjunto (Levin, 2012). A pesquisa-ação reúne ação e reflexão, teoria e prática, como forma de atender ao foco em contribuições diretas para questões que entrecortam o cotidiano dos participantes, permitindo o crescimento das pessoas e comunidades onde ocorrem (Brydon-Miller, Greenwood \& Maguire, 2003).

A alternância entre ciclos de ação e reflexão é realizada por meio de ciclos iterativos. Os ciclos de ação são compostos pelo envolvimento do pesquisador com os participantes e o campo de estudo, demandando empatia e abertura para os sentimentos, sensações, caos e imprevisibilidade que compõem as relações humanas. Segundo Ragland (2006), os ciclos de ação envolvem abertura para a dimensão da corporeidade, deixando emergir os conhecimentos tácitos e as relações corporificadas que envolvem os encontros humanos. Em síntese, nesta etapa a pesquisa se desenrola a partir do envolvimento emocional, intelectual, relacional e corporificado do pesquisador com o contexto investigado, através da ação (Reason \& Torbert, 2001).

Os ciclos de reflexão, por outro lado, envolvem um distanciamento destas relações e o exercício das habilidades críticas e analíticas do pesquisador. É o 
momento de criação de explicações e descrições do fenômeno estudado, buscando construir uma narrativa científica adequada ao contexto acadêmico e relevante para a comunidade científica (Levin, 2012).

Tendo apresentado os principais aspectos que caracterizam, de maneira geral, os conceitos de pesquisa-ação em que nos embasamos, delinearemos a forma como tais conceitos foram utilizados no contexto de nosso estudo, evidenciando como as propostas mais gerais têm sido aplicadas no contexto singular desta pesquisa. Entendemos que este exercício confere relevância ao entendimento de que os conceitos e ferramentas metodológicas partem de um ponto de vista mais amplo acerca da prática científica. Todavia, como nosso estudo evidencia, o delineamento e realização de cada pesquisa é um fenômeno singular, isto é, o uso das metodologias ocorre de forma particular, contextualmente localizada, e leva em conta as especificidades da investigação proposta.

Assim, destacamos três aspectos da pesquisa-ação que foram utilizados de maneira mais evidente em nosso estudo: (1) o foco pragmático; (2) a co-participação; e (3) os ciclos de ação-reflexão. O foco pragmático refere-se à forma como o estudo foi conduzido em parceria com as terapeutas-participantes, delineando um processo de investigação que ocorreu no contexto da prática e demandou que as terapeutas estivessem engajadas no processo de pesquisa como co-pesquisadoras. Neste sentido, vimos desenvolver-se também a co-participação, pois o andamento da pesquisa foi baseado no contexto das participantes e se desenrolou em colaboração com as mesmas - ou seja, ao mesmo tempo em que adequou-se às demandas e características específicas da prática clínica, também incluiu as terapeutasparticipantes nos processos de análise dos dados, em uma participação que foi para além do momento de construção dos dados da pesquisa.

Por fim, a construção e análise dos dados se deu através de processos de ação e reflexão, uma vez que momentos de imersão no campo foram seguidos de etapas de distanciamento e análise do material. Em seguida, houve nova imersão no campo para diálogos sobre as análises produzidas, com subsequente etapa de análise das novas informações produzidas. Tais etapas serão detalhadamente descritas adiante, neste capítulo.

Em síntese, vemos que o delineamento da pesquisa ofereceu uma tentativa de estabelecer perguntas, objetivos, métodos e discussões que fomentem os debates e o avanço nos conhecimentos produzidos no âmbito acadêmico. Ao mesmo tempo, o 
processo de pesquisa e, principalmente, os métodos de produção dos dados são coerentes com o cotidiano da prática clínica e atendem à demandas e desafios vividos pelas profissionais. Buscamos não apenas produzir dados que sejam relevantes para a prática profissional, mas também dirigimos esforços para que o próprio processo de construção da investigação fosse relevante para as participantes.

Ressaltamos, assim, contribuições do estudo para a prática profissional, abordando-as sob dois pontos de vista: para os participantes da pesquisa e para a comunidade profissional mais ampla.

Por se tratar de uma pesquisa-ação, o delineamento da pesquisa ofereceu contribuições imediatas para as terapeutas-participantes, e para compreende-las é necessário explicitar algumas condições que acompanham o exercício profissional do terapeuta familiar. Ao longo da formação em TF, os alunos atendem famílias em estágios e/ou clínicas-escola. Nestes atendimentos, costumam organizar-se em coterapia, atendimento em equipe, ou em salas com espelho unidirecional, em que o(s) terapeuta(s) são assistidos por outros alunos e professores. Tais contextos são ricos em termos de diálogo sobre o caso atendido e a atuação dos alunos, constituindo-se em ambientes de trocas e aprendizagem. Após a formação, tais contextos costumam ficar reduzidos, e a prática cotidiana em consultório consolida-se de forma solitária, com poucas oportunidades de diálogos que fomentem a reflexão sobre os atendimentos.

Neste particular, nossa pesquisa ofereceu contextos de retorno imediato para as terapeutas-participantes, uma vez que criamos diversos momentos de diálogos sobre os atendimentos. A investigação científica aliada a um contexto de interlocução profissional transformou-se em rica oportunidade de aprendizagem para os envolvidos no estudo - pesquisadora, terapeutas e clientes. Em relação a estes últimos, é provável que o contexto de frequentes conversas profissionais entre as terapeutas tenha qualificado o processo terapêutico, devido ao caráter crítico e reflexivo das conversas entre terapeutas, as quais abordaram tanto questões sobre o caso em si, como a atuação das profissionais e sua relação com os clientes.

Considerando a comunidade profissional mais ampla, ressaltamos que a pesquisa, ao construir conhecimentos a partir da prática clínica cotidiana, posiciona as terapeutas familiares como construtoras de conhecimentos sobre suas próprias práticas (Rasera \& Guanaes, 2006). Este aspecto empodera as profissionais, 
colocando-os como produtoras de sentidos acerca dos processos terapêuticos que constroem em conjunto com os clientes.

\subsection{Criando rigor e qualidade no processo de pesquisa}

Esta seção está voltada para a descrição de alguns critérios para avaliação da qualidade de pesquisas orientadas pela pesquisa-ação e pelo construcionismo social. Foge ao nosso escopo reunir e descrever os diversos critérios que compõem a avaliação da qualidade de estudos qualitativos - para tanto, há uma pluralidade de autores e obras que podem ser consultadas (por exemplo, Goetz \& LeCompte, 1984; Gunther, 2006; Ollaik \& Zimmer, 2012). Com foco nas perspectivas que compõem a estrutura metodológica desta investigação, buscaremos iluminar alguns pontos que temos considerado como relevantes no desenvolvimento de nossa pesquisa.

Entendendo que o mundo social - e, portanto, a ciência - é composto e organizado por múltiplos discursos, os quais são articulados em torno de julgamentos de valor (McNamee \& Hosking, 2012), acreditamos ser pertinente explicitar ao leitor quais são os critérios de qualidade e rigor a partir dos quais são avaliadas as pesquisas orientadas pelas perspectivas utilizadas neste estudo. Nas palavras de Ibañez (1994), validar um conhecimento é concebê-lo como uma construção social, em que o valor do conhecimento produzido não está contido em si mesmo, mas sim na importância que este assume no contexto social, histórico, econômico e cultural em que é produzido.

Ao descrever o rigor na pesquisa orientada pelo construcionismo social, McNamee (2010) indica a importância do pesquisador explicitar os conceitos que norteiam a concepção do método, bem como os autores e a literatura com a qual o estudo se aproxima no campo científico. De maneira semelhante, ao descrever a analisar os critérios de qualidade da pesquisa-ação, Huang (2010) afirma que o pesquisador deve esforçar-se para deixar claro os critérios que norteiam as escolhas referentes ao método do estudo. Para esta autora, dificilmente um estudo consegue atingir, com excelência, todos os critérios de qualidade exigidos de uma produção científica. Desse modo, o mais importante é explicitar as escolhas feitas ao longo do processo de pesquisa, descrevendo o que se ganha e perde com as escolhas realizadas. 
No tocante, mais especificamente, ao manejo e redação das informações da pesquisa, M. Spink e Lima (1999/2013) afirmam que as pesquisas orientadas pela construção social consideram o rigor como "a possibilidade de explicitar os passos da análise e da interpretação" (p. 78). Definem o processo interpretativo como uma produção de sentidos do pesquisador acerca dos dados, divergindo de um entendimento da análise como uma revelação ou retrato da realidade. Considerado uma produção de sentidos, o trabalho analítico e interpretativo do pesquisador é da ordem da intersubjetividade, constituindo-se em um conhecimento possível (e não definitivo), situado na relação específica que se estabelece entre pesquisador e participantes e, mais amplamente, em relações sociais e institucionais que influenciam o fazer em ciência.

A proposta de M. Spink e Lima (2013) dá especial relevância à necessidade do pesquisador explicitar, tão detalhadamente quanto possível, os passos e etapas que culminaram na construção de categorias e temáticas de análise do material. A nosso ver, tal orientação busca dissipar o mito de que, em pesquisa qualitativa, as categorias surgem "magicamente" após o contato do pesquisador com as informações da pesquisa. Para além de indicar rigor, também indica um posicionamento ético do pesquisador que preocupa-se em possibilitar a compreensão da lógica e dos passos que guiaram a forma como os dados foram analisados. A produção do texto científico deve ser tal que os leitores não precisem "confiar no pesquisador" em relação aos dados empíricos obtidos no campo de investigação e às formas de análise dos mesmos (Levin, 2012).

Levin (2012) traz importantes reflexões em relação à manutenção do rigor e da relevância de um estudo científico baseado na pesquisa-ação. $\mathrm{O}$ autor descreve o rigor como característico das pesquisas que estão em conformidade com as regras da produção científica: ao estabelecer um objetivo baseado no contato com o campo e na revisão de literatura, busca-se aplicar metodologias científicas para a construção de dados empíricos que, analisados, devem trazer novos insights e conhecimentos para a ciência. Por outro lado, a relevância é definida como característica do trabalho científico elaborado em torno de questões de pesquisa pertinentes e importantes para os participantes e o contexto estudado.

Rigor e relevância fazem parte dos processos de pesquisa-ação, e devem ser fonte de atenção e cuidado. Para Levin (2012), muito rigor na realização da pesquisa pode gerar resultados que têm pouca relevância. Do mesmo modo, a busca por alta 
relevância pode deixar em segundo plano a precisão e o rigor no trabalho analítico. A construção de recursos para lidar com estes desafios foi alvo de esforços em nosso processo de pesquisa, como buscamos dar visibilidade ao longo do texto.

Nos processos de produção e análise dos dados, buscamos rigor científico na clara descrição metodológica do estudo, bem como uma articulação entre os objetivos, métodos e análises propostas nesta tese. Ao mesmo tempo, nos dedicamos à produção de processos de construção de conhecimento que, de alguma maneira, possam trazer contribuições imediatas para os participantes - terapeutas e clientes e também para o campo da TF mais amplamente. E, com foco nas produções futuras da pesquisa, na forma da tese e textos científicos, buscaremos utilizar meios de divulgação adequados, relevantes e atraentes para as nossas diferentes audiências tanto a comunidade científica, como os participantes. É no contexto destas tensões, desafios e processos que se deu a produção dos dados e a análise deste estudo, que apresentamos a seguir.

\subsection{Construção do contexto da pesquisa}

Nosso estudo afina-se com a ampliação do conceito de pesquisa de campo proposta por P. Spink (2003), em que o campo de estudo é considerado um campotema, ou seja, "não é mais um lugar específico, mas se refere à processualidade de temas situados" (p. 18) que mantêm relação com o objeto de pesquisa. O pesquisador se insere na teia de ação deste campo-tema ao estabelecer contato com quaisquer aspectos que o conecte com a temática: revisão da literatura, conversas informais, cursos, palestras, congressos, pesquisas de campo, etc. Neste sentido, o campo-tema não se define por uma materialidade específica, mas por um "complexo de redes de sentidos" (p. 28) que envolvem tudo aquilo que está relacionado ao objeto de pesquisa.

Sob este ponto de vista, a construção do contexto da pesquisa é considerada uma forma de inserção no campo-tema e, neste sentido, "não há múltiplas formas de coleta de dados, e, sim, múltiplas maneiras de conversar com socialidades e materialidades em que buscamos entrecruzá-las, juntando os fragmentos para ampliar vozes, argumentos e possibilidades presentes” (P. Spink, 2003, p. 37). Desse modo, a imersão no campo-tema desta pesquisa faz parte de uma história anterior 
das pesquisadoras - que estão inseridas no campo da TF através de contextos de formação, ensino e práticas profissionais - e também envolve a participação em contextos específicos proporcionados pelo desenvolvimento do estudo, tais como congressos, workshops e palestras. A imersão nestes contextos foi um dos recursos que ofereceu subsídios para análise e compreensão das práticas investigadas. Todavia, também houve a construção de materialidades e relações específicas para este estudo.

\subsubsection{Contexto}

O contexto de produção de dados foi o consultório onde as duas terapeutasparticipantes do estudo, Anna e Lina4, exercem sua prática profissional privada. Para a produção dos dados, foi formada uma dupla de atendimento com cada terapeutaparticipante. A este respeito, é importante esclarecer que a prática clínica com atendimentos em duplas de terapeutas é comum na TF, especialmente no período de formação. A clínica privada acaba por se consolidar sem este recurso devido ao aumento do custo dos serviços prestados e a impossibilidade de articulação de alguns aspectos práticos, como disponibilidade de horários e dificuldade de encontrar parceiros(as).

Uma vez que o processo terapêutico em clínica particular, em geral, não possui um período de duração pré-estabelecido, definimos que os dados da pesquisa relativos aos atendimentos clínicos fossem compostos por 10 sessões com cada terapeuta-participante, independente destas serem realizadas com a mesma família.

A escolha por este número de participantes e de sessões esteve pautada na natureza qualitativa do estudo, em que busca-se um corpus que, o mesmo tempo que seja diverso, possa ser analisado em profundidade. A partir da imersão no contexto de estudo, entendemos que as informações construídas possuem uma densidade que permitiu a construção de um processo analítico que desse conta do objetivo geral e específicos da pesquisa.

Em relação ao contato com o contexto de estudo, acreditamos ser importante destacar que, uma vez iniciada a pesquisa, a dimensão metodológica ganhou uma relevância que inicialmente não estava prevista, pois o delineamento construído

4 Todos os nomes dos participantes são fictícios. 
oferece uma contribuição original para o campo científico como uma proposta para realização de investigações científicas sobre a prática clínica em TF. Neste sentido, consideramos que a consistência da proposta metodológica não está atrelada à uma maior ou menor quantidade de participantes e sessões utilizadas para a produção dos dados, mas sim à possibilidade de constituir-se em um dispositivo que gere informações úteis tanto para pesquisador quanto para participantes.

Com esta escolha, ecoamos as propostas de autores que afirmam ser necessário, na construção de estudos científicos sobre a prática clínica, a elaboração de delineamentos coerentes com o cotidiano e as especificidades do contexto que envolve a prática clínica (Bardal, 2008; Brydon-Miller, Greenwood \& Maguire, 2003; Dick \& Greenwood, 2015; Gourman, 2011; Haene, 2010; Hickman, Arnkoff, Glass \& Schottenbauer, 2009; Huang, 2010; Lebow, 1988; Ragland, 2006; Reason \& Torbert, 2001; Sexton \& Datchi, 2014; Smith \& Southern, 2005; Strong \& Gale, 2013).

A configuração do contexto da pesquisa também esteve condicionada à diretrizes para participação da pesquisadora no atendimento, as quais foram além das normativas éticas que direcionam as pesquisas com seres humanos (Brasil, 2012), buscando uma orientação ética dialógica e adequada às especificidades do contexto (McNamee, 2015). Estas diretrizes foram apresentadas para as terapeutas no encontro pessoal em que foram convidadas para fazer parte do estudo e, posteriormente, aos clientes no momento em que estes foram convidados. Foram estas:

A pesquisadora não recebeu remuneração pela sua participação nos atendimentos5;

> A pesquisadora fez parte do processo terapêutico ao longo de toda sua duração, mesmo que este se estendesse por um período posterior à produção dos dados;

$>$ As terapeutas-participantes tiveram liberdade de selecionar os clientes que seriam convidados a fazer parte da pesquisa - caso convidassem clientes cujo processo terapêutico estivesse em andamento, o convite seria feito em uma conversa entre a terapeuta e os clientes, no qual estes teriam plena liberdade de rejeitar o convite; caso o convite fosse feito

\footnotetext{
5 Inicialmente, as diretrizes da pesquisa estabeleciam que apenas a pesquisadora não receberia remuneração pelos atendimentos realizados, ficando em aberto a questão da remuneração das terapeutas-participantes, uma vez que seria possível convidar clientes que seriam atendidos em sua clínica particular. Todavia, como ambas as participantes optaram por oferecer os atendimentos no formato de clínica social, este critério acabou aplicando-se também à elas.
} 
para clientes que iriam iniciar o processo terapêutico, a terapeuta poderia configurar este convite de forma que se sentisse confortável e não influenciasse negativamente sua imagem profissional.

\subsubsection{Participantes}

Os participantes deste estudo foram: (a) duas terapeutas familiares que exercem a prática clínica de atendimentos a famílias, em clínica privada; e (b) os clientes atendidos por estas terapeutas para a produção dos dados da pesquisa: dois casais e uma família com três membros (pai, mãe e filha), totalizando 7 clientes.

As terapeutas-participantes foram convidadas a partir da metodologia "snowball sampling", ou "bola de neve", a qual é amplamente utilizada em pesquisas qualitativas com populações de difícil acesso (Biernacki \& Waldorf, 1981; Faugier \& Sargeant, 1997). Esta metodologia busca a criação de uma cadeia de referência, em que um participante indica outro(s) possível(eis) participante(s).

Consideramos que nossos participantes fazem parte de uma população de difícil acesso porque, em geral, a prática clínica é investigada por meio de pesquisas em locais de ensino ou institutos de formação, ocasionando a produção de conhecimento em contextos dissonantes do que se encontra na prática clínica cotidiana (Sexton \& Datchi, 2014; Strong \& Gale, 2013).

Faugier e Sargeant (1997) também indicam esta metodologia para contextos cujas informações são delicadas e privadas, bem como em empresas e organizações, como é o caso do contexto de trabalho das terapeutas-participantes.

Levando em conta estas questões, consideramos que o uso da metodologia bola de neve foi um dispositivo metodológico útil ao permitir configurar um estudo cujo contexto se assemelhou ao cotidiano do campo pesquisado.

O uso da metodologia "bola de neve" também definiu alguns limites para a produção dos dados da pesquisa. Considerando que as pesquisadoras foram o início da cadeia de referência, inevitavelmente o convite foi realizado à uma terapeuta (Anna) com a qual temos proximidade e que partilha do mesmo contexto profissional e círculos de convivência das pesquisadoras no campo da TF, o qual é marcadamente definido pela sensibilidade às propostas construcionistas sociais para a prática clínica. A continuidade da cadeia de referência, por parte de Anna, seguiu este mesmo 
critério de escolher participantes com as quais ela tinha proximidade e que imaginava que aceitariam fazer parte de um estudo dessa natureza. Assim, os dados ficaram restrito a participantes que baseiam sua prática clínica nas ideias construcionistas sociais e sistêmicas, considerando a orientação teórica dos institutos onde elas fizeram sua formação.

As terapeutas-participantes atenderam aos seguintes critérios de inclusão:

$>$ Exercer, no momento de produção dos dados da pesquisa, a prática clínica de atendimento a famílias;

$>$ Ter concluído a formação como terapeuta familiar, uma vez que a pesquisa não foi relacionada a contextos de formação - este critério buscou excluir terapeutas em formação, momento em que aprendem diferentes modelos e epistemologias, e são encorajadas à experimentação de diferentes posturas teóricas;

O primeiro convite à participação foi realizado à Anna, em junho de 2016. Neste encontro, ela nos indicou diversas colegas de profissão com as quais poderíamos entrar em contato. Assim, falamos com Lina em agosto de 2016, que também aceitou participar do estudo.

A partir da participação de Anna, foram realizadas 31 sessões de terapia de casal, entre setembro de 2016 e dezembro de 2017. Após este período, a terapia continuou em um formato de terapia individual apenas com a esposa (ainda em coterapia, ou seja, Anna e eu participamos dos atendimentos), e foram realizadas 12 sessões entre fevereiro e dezembro de 2018. Para a pesquisa, utilizamos informações das dez primeiras sessões de terapia de casal.

A partir da participação de Lina, foram realizadas 4 sessões de terapia de família e 11 sessões de terapia de casal, entre março e agosto de 2017. Para a pesquisa, utilizamos informações de três sessões da terapia familiar e sete sessões da terapia de casal.

A seguir, apresentamos aspectos da construção da relação com cada terapeutaparticipante e as informações dos processos terapêuticos realizados. Arieli, Friedman e Agbaria (2009) descrevem duas perguntas que devem ser endereçadas à medida que o pesquisador se insere no contexto de pesquisa, em busca de estabelecer relações de parceria e colaboração com os participantes, são elas: qual é o interesse e a necessidade do participante quando ele aceita o pesquisador em campo? Como 
pesquisador e participante definirão papeis, tarefas, limites e autoridade de cada um, no processo de pesquisa?

Segundo as autoras, estas perguntas devem ser abertamente conversadas no processo de pesquisa, uma vez que expectativas não atendidas, por parte dos participantes, podem gerar baixos níveis de engajamento e participação na pesquisa. Ademais, afirmam que a definição da forma como se dará o envolvimento de cada pessoa - no caso, terapeuta-pesquisadora e terapeuta-participante - é de suma importância para que se estabeleça uma relação que favoreça a colaboração. Levamos em consideração estes parâmetros na construção da relação com Lina e Anna, e as respostas a tais questões constam nas informações registadas nos diários de campo e são incluídas no relato que se segue.

\subsubsection{A construção da relação com Anna}

Anna é terapeuta familiar há cerca de 7 anos, embora exerça a prática clínica desde o final da década de 1980. Fez sua formação em TF em um instituto cuja orientação teórica é o construcionismo social, e afirma que embasa sua atuação, predominantemente, nas práticas colaborativas propostas por Harlene Anderson, nos processos reflexivos descritos por Tom Andersen e nas práticas narrativas propostas por Michael White e David Epston.

Conhecemos Anna pelo convívio em diferentes contextos ligados à prática de TF. O contato foi inicialmente realizado por e-mail, e combinamos um encontro pessoal para explicar a proposta da pesquisa.

Anna recebeu o convite com receptividade e uma forte intenção de colaborar. No início de nossa conversa de convite, ela imaginava que seria realizada uma entrevista. Ao compreender que seria formada uma dupla para atendimento de uma família em co-terapia, a surpresa ficou evidente em sua linguagem corporal, e seu entusiasmo aumentou. Neste momento - e algumas vezes ao longo dos meses em que atendemos juntas - Anna afirmou que a prática clínica é muito "solitária” (sic), e a redução dos momentos de supervisão de casos clínicos, ao longo dos anos, contribui para essa solidão que envolve as atividades cotidianas do terapeuta familiar. Neste sentido, afirmou que a participação na pesquisa seria uma possibilidade de trocas sobre o atendimento. Anna também disse que a co-terapia em clínica particular é 
uma prática ainda "inovadora" para alguns profissionais, embora veja que é mais comum em outros lugares, como a cidade de São Paulo.

Ao final do encontro, Anna disse que estava muito contente com a possibilidade de participar do estudo, e que isto seria um "projeto" em sua vida (sic) nos próximos meses, dada a importância que teria em sua prática e a dedicação de tempo que tal participação demanda. Logo pegou sua agenda, e definimos horários em comum para iniciar os atendimentos.

Uma questão central levantada por ela neste encontro foi a vontade de não abrir este convite para clientes que a procurassem em contexto de clínica particular. Disse que não se sentiria à vontade, por estar fortemente inclinada a achar que os clientes não topariam fazer parte de um estudo e provavelmente não voltariam mais ao consultório. Considerando a estranheza que a realização de uma pesquisa dessa natureza em sua clínica privada, Anna ativou recursos de sua rede profissional, falando sobre a possibilidade de fazer atendimentos no formato de clínica social, em que um número específico de sessões (no caso, dez) seriam oferecidas a uma família, em caráter gratuito, com a condição prévia de aceitarem fazer parte do estudo. Concordamos que esta forma de construção do contexto atendia as necessidades de ambas as partes - pesquisadora e terapeuta-participante.

Algumas semanas depois, Anna telefonou dizendo que havia entrado em contato um casal interessado em receber atendimentos gratuitos. Nesta ocasião, definimos especificidades da nossa atuação no atendimento - detalhes sobre como convidar o casal para a pesquisa (por exemplo, abordar aspectos éticos com uma linguagem acessível), e em relação ao papel de cada uma no atendimento: para Anna, se pudéssemos dividir a responsabilidade pela conversa com o casal, seria algo "maravilhoso" (sic) e que atenderia suas expectativas para esta parceria; mas, se a pesquisadora desejasse ficar em uma posição de escuta e observação durante os atendimentos, para ela seria algo tranquilo. Definimos, assim, que a pesquisadora conduziria, na primeira conversa com o casal, as explicações sobre a pesquisa. Ao longo do processo terapêutico, Anna ficaria responsável pela condução das conversas, com abertura para que a pesquisadora participasse a qualquer momento, com perguntas, colocações, reflexões, etc.

Em suma, vemos que, para Anna, a participação no estudo e a formação da dupla de terapeutas foram vistas como um recurso de diálogo e aprendizagem, análogo aos encontros de interlocução e discussão de casos, que são comuns na 
prática clínica. Além disso, a participação no estudo pareceu envolver a construção de um contexto "inovador", colocando-nos em uma posição de vanguarda e avanço do conhecimento no contexto local onde se desenvolve a pesquisa. Estas condições delinearam uma expectativa de parceria que fosse frutífera em termos de produção conjunta de conhecimento, de modo que ela sentisse que estava "aprendendo" e ganhando algo com esta parceria, a partir da "possibilidade de trocas sobre o atendimento" (sic).

Ao longo da condução da pesquisa, a pesquisadora foi responsiva à forma como o estudo foi entendido por Anna, pautando a maneira como negociamos nossa parceria. Bastante ênfase foi dada aos momentos de diálogo após cada atendimento, entendendo que estes respondiam aos interesses e necessidades de Anna. Além disso, a participação da pesquisadora nos atendimentos foi se tornando mais ativa, à medida em que afinávamos nossa forma de trabalhar em conjunto. Papeis, tarefas, limites e predominância de cada terapeuta foram fatores negociados no início da parceria, e reajustados à medida em que criávamos uma sintonia em nosso agir.

Também percebemos o esforço, por parte de Anna, em termos de carga horária dedicada à pesquisa - a descrição do estudo como um "projeto" em sua vida nos atentou ainda mais às demandas e ao impacto que a participação tem na vida cotidiana da participante. Neste sentido, flexibilizamos prazos para cumprimento de cada etapa do estudo (por exemplo, início dos atendimentos e agendamento da conversa de interlocução), entendendo esta flexibilidade como uma forma de responsividade às possibilidades da participante.

Além disso, o período de realização do atendimento também foi flexibilizado, conforme as demandas apresentadas pelos clientes - inicialmente, foram oferecidas 10 sessões de atendimento. Uma vez finalizadas, os clientes solicitaram a continuidade do acompanhamento, e um novo combinado foi realizado com o casal, em que continuaríamos prestando os atendimentos gratuitos e, em conjunto, avaliaríamos quando encerrar o processo terapêutico. Após um período, o marido resolveu não seguir com a terapia de casal, e a esposa nos pediu que continuássemos acompanhando-a, devido à tensão que ainda viviam no casamento. Foram, assim, realizadas 12 sessões com a esposa, também em caráter gratuito e no formato de coterapia. As escolhas que pautaram as mudanças e flexibilidade de arranjos neste atendimento foram sendo realizadas ao longo do processo, e a partir de nossa responsividade ao que a relação com os clientes nos apresentava. Nestas tomadas de 
decisão, os critérios de escolha que permeavam nosso agir estavam mais próximos de uma ética voltada para as especificidades da prática clínica do que o foco na pesquisa que originou o atendimento, sobretudo para Anna - mesmo que a etapa de produção de dados estivesse finalizada, julgamos importante seguir os atendimentos até o momento em que nós, terapeutas, entendêssemos que seria possível finalizar o processo terapêutico em curso. De acordo com este posicionamento e seguindo as próprias orientações éticas estabelecidas para esta pesquisa, a pesquisadora mantevese como terapeuta do caso até sua finalização, em dezembro de 2018.

\subsubsection{A construção da relação com Lina}

Lina é terapeuta familiar há cerca de quinze anos, período em que começou a atender casais e famílias. Fez sua formação em TF em um instituto de orientação teórica construtivista e construcionista social, e afirma atuar, predominantemente, a partir dos referenciais teóricos da teoria sistêmica, das práticas narrativas propostas por Michael White e David Epston, das práticas colaborativas propostas por Harlene Anderson e os processos reflexivos definidos por Tom Andersen.

Nosso contato com Lina deu-se através da indicação de Anna. Tal contato foi realizado por telefone e marcamos um encontro pessoal, que aconteceu em agosto de 2016, em seu consultório. Assim como Anna, Lina exprimiu preocupações em relação a convidar pessoas que lhe procurassem na clínica particular. Disse que não achava um bom "cartão de visita" (sic). Afirmou que, para participar, iria acionar sua rede profissional e propor atendimentos a uma família em forma de clínica social, ou seja, sem custo nenhum e com um número pré-estabelecido de sessões (no caso, dez).

À medida que conversávamos sobre a pesquisa, Lina trouxe diversas perguntas - sobre as conversas após as sessões, a interlocução, as transcrições, a dedicação de tempo para leitura do material. Algumas perguntas foram respondidas conforme $o$ que estava previsto no delineamento do estudo; em relação à outras dúvidas, Lina foi informada que a proposta da pesquisa era flexível e poderíamos nos ajustar conforme o andamento de nossa parceria e do processo terapêutico.

Uma questão importante para ela foi a forma como se daria a participação da pesquisadora no atendimento. Para ela, uma participação "silente" como observadora não parecia ser uma opção confortável para ela ou para os clientes, embora 
compreendesse que uma distância maior pudesse auxiliar na análise dos dados. Neste ponto, foi reiterado à Lina que a vivência deste duplo papel - como pesquisadora $e$ terapeuta - era parte do delineamento da pesquisa, e que contávamos com recursos metodológicos para lidar com estas duas posições (a saber, o exercício da reflexividade por parte da pesquisadora e a alternância entre os ciclos de ação e reflexão). Nesse sentido, seria possível ter um papel ativo no atendimento sem prejudicar o processo de pesquisa.

Por fim, Lina trouxe uma última questão em relação à poder participar do estudo - afirmou que o foco da pesquisa em "identificar os porquês" (sic) e as inspirações para suas ações estaria condicionado a ela poder dizer "não sei” de vez em quando. Mesmo que estas afirmações tenham sido feitas em um tom leve e descontraído, entendemos que traziam uma preocupação relevante em relação à forma como ela seria posicionada no estudo como investigadora de si mesma. Vimos essa preocupação como um sinalizador importante para as perguntas que seriam feitas na interlocução. No momento daquela conversa, Lina foi informada que esta era, certamente, uma possibilidade, havendo abertura para estes momentos em que não é possível dar uma justificativa lógica e racional para as ações.

Ao final, dizendo estar "curiosa" em relação à como seria a pesquisa, Lina concordou em fazer parte do estudo. Todavia, disse que só teria disponibilidade para iniciar os atendimentos em janeiro ou fevereiro de 2017.

Ao longo das etapas de participação de Lina no estudo, fomos responsivas à estas preocupações e pedidos relativos às nossas posições - tanto no atendimento como na pesquisa. Os atendimentos tiveram início no começo do ano de 2017, quando Lina conseguiu manejar sua agenda de atendimentos. Não foram realizadas conversas após cada sessão de atendimento, tendo em vista que, muitas vezes, Lina tinha outros atendimentos ou compromissos logo após a sessão. Além disso, a pesquisadora exerceu um papel de co-terapeuta que foi para além da observação silente, ainda que Lina tomasse a frente na condução da conversa.

$\mathrm{Na}$ interlocução após os atendimentos, atenção foi dada aos momentos em que o "não sei” emergiu, por parte de Lina, tomando-os como parte legítima da conversa ao perceber que algumas perguntas voltadas para a busca e nomeação dos "porquês" e inspirações pareciam não se encaixar com aquilo que Lina desejava falar ou refletir acerca de nossas ações, tais questões do roteiro de interlocução foram abandonadas para acompanha-la naquilo que ela desejava falar. Esta posição, como pesquisadora, 
foi desafiadora e demandou um monitoramento constante das perguntas da pesquisadora e das respostas de Lina (tanto verbais quanto não-verbais, como tom de voz e indicações corporais de conforto ou desconforto com a conversa que acontecia no momento). Lidar com este desafio tornou-se mais fácil a partir da confiança nas premissas da pesquisa-ação e da convicção de que o processo de pesquisa precisa ser proveitoso e fazer sentido tanto para pesquisadora quanto para os participantes.

\subsubsection{A construção da relação com os clientes}

Neste item, descrevemos como foi o contato inicial com os clientes participantes do estudo, e quais foram as principais queixas e pedidos apresentados por eles.

\section{Casal Luis e Ligia}

Luis e Ligia foram atendidos a partir da participação de Anna. O casal estava inscrito na fila de espera de uma rede de atendimentos que oferece TF em caráter gratuito na cidade onde se desenvolveu o estudo. O contato inicial foi realizado entre Luis e Anna, por telefone, ocasião em que a terapeuta agendou nosso primeiro encontro.

Na primeira sessão com o casal, apresentamos as condições de realização do atendimento, em uma conversa estruturada de forma acessível, evitando o vocabulário excessivamente acadêmico. Luis e Ligia fizeram perguntas sobre a gravação em áudio e o manejo das informações da pesquisa. Após esclarecidos, ambos concordaram em participar, e seguimos à assinatura dos Termos de Consentimento. Este momento durou cerca de meia hora, e então começamos a terapia de casal propriamente dita.

À época, Luis e Ligia estavam casados há doze anos, e se conheciam há 21 anos. Luis tinha 45 anos e estava desempregado há cinco. Possui ensino superior completo e, no momento, estava fazendo pós-graduação. Ligia tem 50 anos e é professora. Antes desse emprego, fez duas graduações e cursos de especialização. O casal não tem filhos.

Luis e Ligia buscaram a terapia porque sentiam-se com dificuldades de comunicação entre si. Nas palavras de Ligia, "a gente conversa muito pouco sobre nós dois”, constatação que é confirmada pelo marido e descrita como o pedido para a 
terapia de casal. À época, ambos faziam terapia individual, mas agora buscavam um foco no relacionamento e um "espaço para falar e ouvir", segundo Ligia.

Como afirmamos anteriormente, foram realizadas 31 sessões de terapia, entre setembro de 2016 e dezembro de 2017. Depois, a partir de um pedido de Ligia, continuamos o atendimento como terapia individual apenas com ela e foram realizadas 12 sessões, entre fevereiro e dezembro de 2018.

\section{Família Silva}

A família Silva foi atendida a partir da participação de Lina. Eles foram encaminhados para TF por uma tia de Amanda, de 22 anos, com quem ela estava morando à época do atendimento, e a sugestão havia sido dada pelo psiquiatra que a estava acompanhando. A principal questão que levava Amanda e seus pais, Renata e Raul, à terapia era a recente tentativa de suicídio da filha. No total, foram realizados 4 encontros presenciais (um com os pais e três com a família), e uma ligação telefônica entre terapeutas e Amanda. Depois deste telefonema, aconteceu o que entendemos que tenha sido uma internação psiquiátrica involuntária de Amanda, e não tivemos mais notícias da família.

Por meio da terapia familiar, Raul, Renata e Amanda buscavam mais entendimento entre si, com o pedido de mudarem as formas de comunicação entre eles e buscando "construir confiança" (sic) na relação. Amanda considerava que ela e os pais viviam "em mundos diferentes" (sic), e gostaria de ser mais aceita. Por sua vez, Renata e Raul tinham questões em relação às escolhas da filha acerca de seu futuro (estudos e emprego), e gostariam de abordar problemas desencadeados devido à rotina de Amanda e suas saídas e passeios com os amigos, questões que despertavam grandes conflitos e brigas que, por vezes, culminavam em episódios de violência física e psicológica.

A primeira sessão foi feita apenas com os pais porque Amanda não compareceu ao encontro. Após três sessões em que todos estiveram presentes, os conflitos familiares e alguns acontecimentos levaram os pais a entender que seria necessário internar Amanda em uma instituição psiquiátrica, mesmo contra a sua vontade. Todavia, após uma conversa telefônica que as terapeutas tiveram com Amanda, não tivemos mais notícias da família, e não sabemos qual foi a decisão dos pais em relação à internação da filha. 


\section{Casal Igor e Vivian}

Como havíamos realizado apenas quatro sessões de terapia a partir da participação de Lina, conversamos entre nós sobre a possibilidade de iniciar um novo atendimento e a terapeuta-participante concordou. Iniciamos, assim, terapia de casal com um casal encaminhado pela rede pública de atendimento, devido a problemas de violência doméstica. Tínhamos poucas informações prévias quando iniciamos o acompanhamento de Igor e Vivian.

Segundo o casal, eles buscavam a terapia como uma maneira de conseguirem se entender melhor e, nas palavras de Vivian, "resgatar o que estava se perdendo entre eles, para não deixar o casamento desandar” (sic). O casal, que estava junto há 23 anos, já havia se separado e reatado diversas vezes ao longo dos últimos anos, movimento este desencadeado pelos episódios de violência doméstica, questões envolvendo consumo de bebida alcoólica e relacionamentos extraconjugais. Eles tinham dois filhos, com idades de 23 e 17 anos.

Ao todo, foram realizadas 11 sessões com Igor e Vivian. Em algumas delas, foram vividos momentos de grande tensão e discussões entre o casal, trazendo desafios para o manejo terapêutico, tanto em relação à construção da aliança entre o casal e as terapeutas, como em relação à construção de um ambiente de segurança e respeito em que as questões pudessem ser trabalhadas de forma a produzir efeitos e ações diferentes das brigas, acusações mútuas e busca de um “culpado” para os acontecimentos.

Entramos em contato com o casal por telefone cerca de dois meses após a finalização do processo terapêutico, para saber como estavam e oferece-los um serviço de atendimentos gratuitos ao qual eles poderiam recorrer caso ainda sentissem necessidade. À época, eles estavam vivendo juntos e ainda lidando com diversos dos desafios que os levaram à terapia. Segundo Vivian, após a terapia eles se sentiam com mais "ferramentas" para lidar com estas questões, mas ainda precisavam "aparar diversas arestas" (sic) da relação entre eles.

\subsubsection{A terapeuta-pesquisadora}

Considerando o contexto delineado em nosso estudo, faz-se necessário que sejam apresentados aspectos da formação e atuação clínica da terapeutapesquisadora. 
A formação em TF foi realizada entre os anos de 2010 e 2012, em um instituto que utiliza as orientações teóricas do pensamento sistêmico, do construtivismo e do construcionismo social. $\mathrm{Na}$ atuação clínica, são consideradas especialmente úteis algumas propostas do pensamento sistêmico, as ideias de Humberto Maturana e Francisco Varela para a compreensão da construção do conhecimento e das relações humanas, a proposta dos processos reflexivos de Tom Andersen, e algumas ideias das práticas colaborativas de Harlene Anderson e das práticas narrativas de Michael White e David Epston. Além destas, são utilizadas diferentes ideias e contribuições teórico-clínicas aprendidas por meio da leitura de artigos científicos, palestras, workshops e congressos. Desde 2012, tem realizado atendimentos clínicos como psicoterapeuta e terapeuta familiar, alternando essa atuação com períodos de dedicação exclusiva à prática de pesquisa.

Uma vez descritos os aspectos que norteiam a construção do contexto e da relação com os participantes do estudo, apresentaremos as etapas do processo de produção e análise dos dados.

\subsection{Produção e análise dos dados: ciclos de ação e reflexão}

No processo de pesquisa-ação, as dimensões de ação e reflexão necessitam ser constantemente manejadas, de modo a propiciar que a pesquisa seja, a um só tempo, útil para os participantes e para a comunidade científica (Dick \& Greenwood, 2015; Levin, 2012). Em nosso estudo, estas dimensões entrecortaram a produção e análise dos dados. Neste sentido, não é possível distinguir, em nossa produção narrativa sobre o estudo, um item sobre a construção e outro sobre a análise. Ambas ocorreram alternadamente, constituindo os diferentes ciclos de ação e reflexão. Em busca de construir um texto organizado e inteligível ao leitor, descreveremos, primeiramente,

as fontes de informação da pesquisa. Em seguida, apresentaremos as etapas de produção e análise dos dados.

As informações que fazem parte da pesquisa são provenientes de cinco fontes: 
Sessões de atendimento: por atendimento, entendemos todo o processo terapêutico de uma família, que é constituído por sessões de frequência periódica. As sessões foram audiogravadas.

Conversas Pós-Sessão: após a maior parte das sessões, aconteceu uma conversa entre a pesquisadora e a terapeuta-participante, em que abordamos questões sobre o atendimento clínico. Estas conversas foram audiogravadas, embora não tenham sido transcritas. A importância desta etapa reside no objetivo prático da pesquisa-ação, em que a pesquisa deve oferecer benefícios concretos para a prática das participantes, dialogando com as expectativas, necessidades e cultura das mesmas (Huang, 2010). Em nosso estudo, esta etapa foi muito valorizada pelas terapeutas-participantes, que a consideram um momento rico de diálogo, trocas e alinhamento da atuação das terapeutas como dupla, exercendo um importante papel no andamento dos atendimentos. Além disso, foi uma etapa que cumpriu uma função característica do campo da $\mathrm{TF}$, que são os encontros de supervisão, interlocução ou discussão de casos, em que o profissional envolvido no atendimento dialoga com um ou mais pares, buscando enriquecimento de ideias e caminhos para a prática, superação de desafios, esclarecimento de dúvidas, etc. Por fim, esta etapa foi de suma importância na pesquisa, auxiliando a pesquisadora a atribuir sentidos às ações das terapeutas na etapa analítica do estudo.

Interlocução Pós-Atendimento: Após o término das 10 sessões, foram realizados dois encontros com cada terapeuta-participante, que denominamos de interlocução pós-atendimento, em que abordamos mais diretamente as ações realizadas nas sessões. Esta conversa foi norteada pelo interesse na construção de justificativas para as ações das terapeutas-participantes, buscando sustentação em autores, recursos e práticas descritas na TF. Nesta etapa, as terapeutas-participantes assumiram o papel de co-pesquisadoras, na medida em que colocaram-se como analistas de si mesmas, auxiliando a pesquisadora a construir sentidos e analisar as ações na prática clínica. Este aspecto é fundamental na pesquisa-ação, pois incluiu as participantes no processo analítico e as 
posicionou como pessoas que sabem de si mesmas, o que diferencia-se de um processo de pesquisa em que a pesquisadora é considerada a expert (Brydon-Miller et al, 2003; Dick \& Greenwood, 2015; Huang, 2010). Assim, esta etapa da pesquisa propôs uma orientação mutuamente reflexiva na investigação científica, em que as fronteiras entre pesquisadora e participantes foram borradas, buscando incluir as vozes e competências das terapeutas-participantes envolvidas, em um trabalho conjunto de análise do material (M. Gergen \& K. Gergen, 2000). Para realização desta conversa, as terapeutas-participantes tiveram contato com uma análise do material transcrito das sessões. A interlocução foi audiogravada e transcrita.

Notas de campo: Ao longo do desenvolvimento da pesquisa, notas de campo foram realizadas para registro de informações relevantes e que poderiam auxiliar no processo de análise. Além de descrever vivências em campo, na relação com todos os participantes do estudo, as notas também descrevem experiências vividas no campo-tema do estudo, decorrentes da participação em congressos, cursos, workshops e conversas informais que versam sobre a TF.

Questionário sobre trajetória profissional: As informações do questionário (Apêndice A) são consideradas norteadores importantes sobre a história da terapeuta com o campo da TF, sobretudo as teorias e perspectivas que elas consideram marcantes em sua prática. Neste sentido, contribuíram para a construção de nosso olhar acerca da prática de cada participante.

Dentre estas fontes, as sessões de atendimento e a interlocução pós-sessão foram as principais origens de informação para análise dos dados. Consideramos que as conversas pós-sessão, as notas de campo e as informações sobre trajetória ofereceram subsídios adicionais para a compreensão das informações geradas nos atendimentos e interlocuções. 
A produção e análise dos dados foram compostas por dez etapas:

1. Convite para participação

2. Formação de uma dupla de atendimento

3. Atendimento de uma família ou casal

4. Transcrição breve das sessões

5. Análise das transcrições breves

6. Construção do material para interlocução pós-atendimento

7. Contato das terapeutas-participantes com o material de interlocução

8. Interlocução pós-atendimento

9. Transcrição da interlocução

10. Análise da interlocução

O quadro 1, a seguir, indica as dimensões de ação e reflexão que perpassaram as etapas apresentadas, caracterizando o estudo no contexto da pesquisa-ação:

1. Convite para participação

2. Formação de uma dupla de atendimento

3. Atendimento de uma família ou casal

4. Transcrição breve das sessões

5. Análise das transcrições breves

6. Construção do material para interlocução pósatendimento

REFLEXÃO

7. Contato das terapeutas-participantes com o material para interlocução

8. Interlocução pós-atendimento

AÇÃo

9. Transcrição da interlocução

10. Análise da interlocução

REFLEXÃO

Quadro 1. Etapas de ação e reflexão envolvidas na produção e análise dos dados 
A seguir, detalhamos cada uma destas etapas, descrevendo os passos que levaram à construção da análise proposta.

\section{ETAPA 1: Convite para participação}

Marcamos um encontro pessoal com cada terapeuta-participante para explicar, em detalhes, o que constituía a participação neste estudo. Nesta conversa, que durou cerca de meia hora com cada uma, levamos uma descrição detalhada do método (Apêndice B). Este foi tanto um recurso de consulta para a pesquisadora (evitando o esquecimento de informações importantes), como uma forma oferecer à possível participante uma estruturação do estudo e informações sobre o que envolveria, de sua parte, a participação na pesquisa.

\section{ETAPA 2: Formação de uma dupla de atendimento}

Após o consentimento em participar, foi formada uma dupla de atendimento entre a terapeuta-participante e a pesquisadora. A divisão de tarefas práticas (como cuidar da agenda dos atendimentos) foi negociada com cada uma, bem como o caráter da atuação de cada terapeuta nos atendimentos.

\section{ETAPA 3: Atendimento de uma família}

Em seguida, passamos para a etapa de atendimento de família. Em caso de desistência do processo terapêutico antes das 10 sessões (como ocorreu com Lina, no caso da família Silva), um novo atendimento teve início, sendo que o corpus ficou composto por sessões realizadas em diferentes atendimentos, até que somassem 10 sessões.

\section{ETAPA 4: Transcrição breve das sessões}

A transcrição breve é uma ferramenta de refinamento e análise das audiogravações, que permite a redação das informações diretamente relacionadas à análise proposta, através de um texto narrativo (não literal), com destaque de dados imprescindíveis para a consulta ao áudio, quando da necessidade de retomar a 
gravação. A transcrição breve, como ferramenta metodológica em pesquisas qualitativas, evita a transcrição de informações desnecessárias ao objetivo do estudo. Consequentemente, diminui o número de páginas de transcrições, reduzindo o volume de informações que o pesquisador necessita manusear na etapa de análise.

Em nosso estudo, a transcrição breve das sessões foi redigida no programa de edição de textos Word, do Windows for Mac ${ }^{\oplus}$. Cada sessão gerou a criação de um documento. A redação da transcrição breve das sessões seguiu algumas diretrizes:

> A página foi configurada com uma margem direita de $6 \mathrm{~cm}$, possibilitando um espaço para anotações durante a análise;

$>$ Todo parágrafo iniciou-se com a indicação do tempo em que a informação está presente no áudio, facilitando a consulta quando necessário;

> A redação das informações foi feita de forma não-literal, exceto por algumas frases literais, indicadas entre aspas, que foram importantes para a compreensão de elementos da conversa (por exemplo, expressões singulares, momentos de tensão, uso do humor, onomatopeias, frases repetidamente utilizadas por alguém).

A redação da transcrição breve é uma atividade interpretativa. Considerando sua natureza não-literal, ela necessariamente envolve uma análise do áudio e sua tradução em texto narrativo, de modo a priorizar certos aspectos e eventos, em detrimento de outros (Guanaes, 2006; Rasera \& Japur, 2007). Como já afirmamos, a escolha daquilo que foi narrado esteve embasada, prioritariamente, nos objetivos do estudo e no foco da análise.

Ao narrar as sessões, demos prioridade à exposição das entonações, posturas corporais, expressões faciais e outros elementos importantes na atribuição de sentidos ao que foi dito por cada pessoa (Guanaes, 2006; Rasera \& Japur, 2007). Consideramos que este é um elemento crucial para a análise interpretativa de áudios que, conforme as normas utilizadas para transcrições literais, pode ficar de fora do material a que o pesquisador recorre para a análise. Portanto, esta é uma potencialidade da ferramenta, ao permitir a descrição de elementos de contexto importantes para a atribuição de sentidos ao processo conversacional. 
A transcrição breve de sessões também é uma ferramenta que permitiu à pesquisadora dar voz a um estilo literário, mais livre e criativo (ainda que circunscrito pelas diretrizes aqui descritas), no processo de construir a pesquisa. Este foi um fator que, além de favorecer a motivação nesta importante etapa da pesquisa qualitativa, é consoante com os entendimentos pós-modernos da prática científica, em que legitima-se as múltiplas formas de redação e análise das informações de pesquisa (M. Gergen \& K. Gergen, 2000).

\section{ETAPA 5: Análise das transcrições breves das sessões}

Cada transcrição breve foi analisada individualmente, possibilitando a construção do material para interlocução pós-sessão. Foram seguidos os seguintes passos para análise de cada transcrição breve de sessão:

$>$ Leitura atenta da sessão, sublinhando cada ação das terapeutas;

$>$ Numeração sequencial e nomeação de todas as ações das terapeutas, com a distinção das ações da terapeuta-pesquisadora e da terapeutaparticipante. A nomeação das ações, sendo uma atribuição de sentidos às mesmas, constituiu-se em parte do processo interpretativo da pesquisadora, e uma das fontes de inspiração para esta atividade foram as conversas pós-sessão;

$>$ Organização das ações em categorias, a partir de agrupamentos por semelhança. Cada categoria foi nomeada e dividida em sub-categorias ou temáticas;

$>$ Para cada sessão, foi criado um novo documento no Word $^{\circledR}$, em que descrevemos cada categoria e as temáticas que a compõem. Para facilitar a descrição da análise, nomearemos este material de "Tabela Descritiva das Categorias”, ilustradas abaixo no atendimento com Lina, na $10^{\mathrm{a}}$ sessão realizada com o casal Igor e Vivian. A cor laranja indica ações que já haviam ocorrido em sessões anteriores, dando-nos pistas sobre regularidades no agir (Guanaes, 2006). Em cada tabela, a coluna da direita indica o número das ações analisadas, atribuído no momento de análise das transcrições breves. Os números em azul indicam ações da 
terapeuta-pesquisadora, e os números em preto indicam ações da terapeuta-participante.
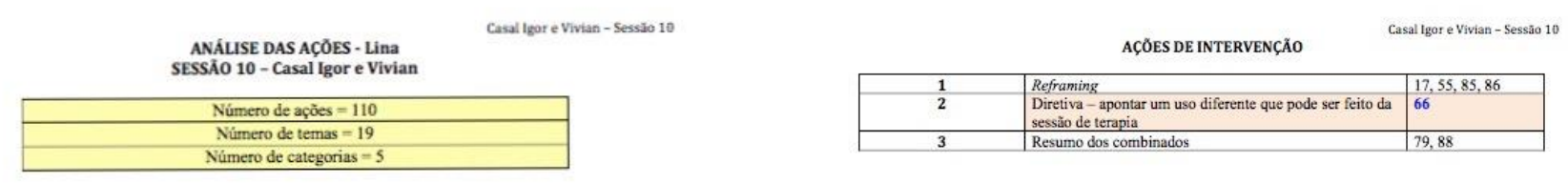

AÇÓES EXPLORATÓRIAS-INVESTIGATIVAS

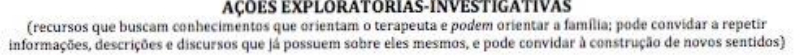

\begin{tabular}{|c|c|c|}
\hline \multirow[b]{3}{*}{1} & Pergunta de esclarecimento & $\begin{array}{l}31,32,51,52,53, \\
67,68,69\end{array}$ \\
\hline & Pergunta como foi a semana & 1 \\
\hline & $\begin{array}{l}\text { Pergunta de exploração (sentidos, sentimentos, saidas } \\
\text { para dificuldades, o que acham do que ouviram as } \\
\text { terapeutas conversar, desejos, sentimentos) }\end{array}$ & $\begin{array}{l}3,10,14,15,16, \\
18,21,22,23,25, \\
28,29,33,34,35, \\
36,48,58,65,75, \\
76,77,99\end{array}$ \\
\hline 2 & Confirmar entendimento & $5,8,74$ \\
\hline 3 & Breve comentirio que enfatiza o que é dito & $\begin{array}{l}9,16,12,42,45 \\
49,54,57,80,83 \\
84\end{array}$ \\
\hline 4 & Interjeiç̌̆o de compreensão & 50,56 \\
\hline 5 & Ouvir em silencio & 61 \\
\hline
\end{tabular}

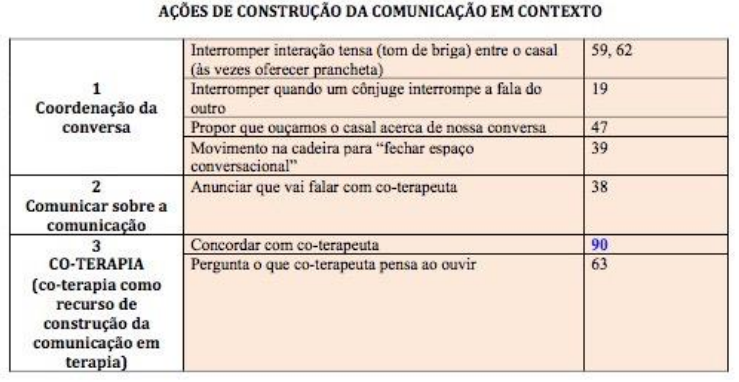

AÇÕES OPERACIONAIS

\begin{tabular}{|c|c|c|}
\hline \multirow{4}{*}{1} & Nomear necessidades/pedidos & 70,78 \\
\hline & Descrever pedido da esposa para marido & 4 \\
\hline & Indicar semelhancas nos pedidos de esposa e marido & 6,7 \\
\hline & $\begin{array}{l}\text { Explorar com X suas possibilidades de atender as } \\
\text { necessidades de } Y\end{array}$ & $71,72,73$ \\
\hline \multirow[t]{2}{*}{2} & Ressaltar mudanças do casal & $\begin{array}{l}13,24,37,81,82 \\
89,94\end{array}$ \\
\hline & Petgunta de ancoragem da mudanca & 95 \\
\hline 3 & Comentário reflexivo & $\begin{array}{l}8,40,41,44,46 \\
60,64,102\end{array}$ \\
\hline \multirow{3}{*}{4} & Pergunta de implicaçăo & $30,87,91,92,93$ \\
\hline & Pergunta a $X$ como pode ajudar $Y$ a mudar & 27 \\
\hline & $\begin{array}{l}\text { Resumo que enfatiza corresponsabilidade na construção } \\
\text { da mudaņ̧a }\end{array}$ & 26 \\
\hline \multirow{2}{*}{5} & $\begin{array}{l}\text { Comentírio sobre metáforas para as relações humanas } \\
\text { (Tênis e frescobol) }\end{array}$ & 98,101 \\
\hline & $\begin{array}{l}\text { Pergunta se pode oferecer ideias de um té́rico sobre } \\
\text { relaçōes humanas }\end{array}$ & $96,97,100$ \\
\hline
\end{tabular}

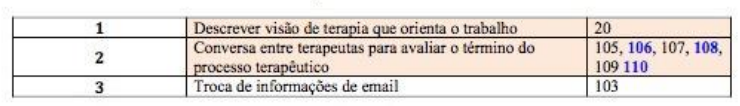

Quadro 2. Exemplo de Tabela Descritiva das Categorias.

ETAPA 6: Construção do material para interlocução pósatendimento

Nesta etapa, foi feita uma análise aprofundada das Tabelas Descritivas das Categorias, conforme os seguintes passos:

> Para cada temática das categorias, selecionamos trechos dos atendimentos que ilustram as ações das terapeutas, e fizemos a transcrição literal dos mesmos;

> Em seguida, por meio de um processo de reflexão acerca das vivências com as terapeutas-participantes, foi elaborado o roteiro para interlocução pósatendimento (Apêndice C para Anna e Apêndice D para Lina). 
$>$ Buscando complementar o material de interlocução, foram criados gráficos das ações da terapeuta no programa Excel, do Windows for $\mathrm{Mac}^{\oplus}$. A proposta destes gráficos foi oferecer um elemento visual que ilustrava o predomínio de determinadas ações, e sua variação ao longo das dez sessões. Tínhamos, assim, uma ilustração do que, comumente, poderíamos descrever como sendo o estilo de atuação de cada terapeuta-participante.

$>$ Também como forma de complementar o material de interlocução, elaboramos resumos de cada sessão do atendimento, ressaltando os principais aspectos que marcaram a conversa terapêutica naquele dia, como forma de auxiliar as terapeutas-participantes na lembrança das sessões analisadas.

\section{ETAPA 7: Contato das terapeutas-participantes com o material para interlocução}

Colocamos, em um único arquivo no Word $^{\circledR}$, as seguintes informações: resumos dos atendimentos, tabelas e trechos que descrevem as ações das terapeutasparticipantes, e os gráficos das ações. Este arquivo foi configurado com um recuo de página maior à direita, permitindo que a terapeuta-participante tivesse espaço para fazer anotações no material. Uma vez impresso e encadernado, este material foi entregue à terapeuta-participante, com o pedido de que ela fizesse a leitura, pois o mesmo seria utilizado como disparador da conversa de interlocução.

\section{ETAPA 8: Interlocução pós-atendimento}

Esta etapa constituiu-se em uma conversa entre pesquisadora e terapeutaparticipante, em que buscamos construir sentidos sobre as ações no atendimento clínico. Como afirmamos anteriormente, o foco era a compreensão das inspirações e critérios que levaram as terapeutas a agirem de determinadas maneiras no atendimento. Buscamos, assim, construir justificativas para as ações, nestas conversas que foram gravadas em áudio.

Esta etapa trouxe uma contribuição fundamental para o processo de pesquisaação. Em uma relação de parceria, a terapeuta-participante tornou-se copesquisadora, de forma análoga ao momento em que a pesquisadora atuou como coterapeuta no momento dos atendimentos. Caminhar neste continuum de parcerias é 
aspecto característico da pesquisa-ação (Brydon-Miller et al, 2003; Dick \& Greenwood, 2015; Huang, 2010).

\section{ETAPA 9: Transcrição da interlocução pós-atendimento}

A interlocução foi transcrita, de modo a possibilitar a análise em profundidade do material.

\section{ETAPA 10: Análise da interlocução pós-atendimento}

As interlocuções pós-atendimento visavam responder, mais diretamente, ao segundo objetivo específico deste estudo. Este momento de produção de sentidos nos possibilitou compreender a escolha de determinados critérios para a ação, além de conhecer as inspirações e recursos dos quais as terapeutas-participantes lançam mão em sua prática clínica. A análise destas informações permitiu a construção de sentidos sobre a integração de teorias e práticas no cotidiano de atendimentos clínicos.

\subsection{Aspectos Éticos: buscando uma ética dialógica}

Em conformidade com a Resolução nº 466 do Conselho Nacional de Saúde (Brasil, 2012), o início da pesquisa e o contato com os possíveis participantes ocorreu apenas após a aprovação do projeto pelo Comitê de Ética em Pesquisa (CEP) da FFCLRP-USP, sob protocolo CAAE: 51065815.0.0000.5407 (Anexo A).

Consideramos que tanto terapeutas como clientes foram participantes do estudo. Todavia, por sua natureza distinta, cada participação foi registrada a partir da assinatura de um Termo de Consentimento Livre e Esclarecido (TCLE) específico (Apêndice E para terapeutas, e Apêndice F para clientes).

Ao contatar os participantes e convidá-los para fazerem parte do estudo, todos foram esclarecidos quanto aos objetivos, justificativas, metodologias e contribuições previstas da pesquisa para o campo da TF. Asseguramos que a participação foi voluntária e que o participante poderia desistir a qualquer momento, sem penalização alguma. Todos foram esclarecidos que a participação não envolvia 
qualquer tipo de remuneração, e não oferecia riscos previsíveis à saúde. A pesquisadora responsável colocou-se à disposição de todos os participantes para prestar assistência ou oferecer esclarecimentos a qualquer momento, além de disponibilizar os dados de contato do CEP da FFCLRP-USP.

Asseguramos que as informações obtidas serão utilizadas apenas para fins de divulgação e aprendizagem em contextos científicos, e o sigilo será resguardado em todas as etapas do estudo e após a finalização do mesmo. Estes esclarecimentos foram prestados verbalmente, e constam nos TCLE, redigidos com linguagem clara e acessível.

No caso específico das terapeutas, tanto no momento do convite quanto ao longo da participação no estudo, enfatizamos que a orientação da pesquisa esteve voltada para o respeito em relação à sua pessoa e à prática clínica por elas exercida, não constituindo-se em um instrumento de julgamento de valor acerca de suas condutas profissionais.

Após iniciar os atendimentos com Anna (a terapeuta com quem primeiro iniciamos a etapa de produção dos dados), tanto nós, pesquisadoras, quanto a terapeuta-participante, percebemos a riqueza e relevância do material que estávamos construindo em conjunto com o casal. Anna expressou o desejo de poder guardar as informações da pesquisa e, futuramente, utiliza-las como material empírico para criação de textos científicos. Ressaltou que, para ela, a gravação em áudio de sessões é uma oportunidade ímpar, que raramente se faz possível no cotidiano da prática clínica em consultório. Ao mesmo tempo, percebemos a relevância de poder constituir um banco de dados com as informações da pesquisa, uma vez que a análise realizada neste estudo não esgota as possibilidades analíticas dos dados.

Neste novo cenário, constituído a partir do andamento da pesquisa, demos entrada a um novo pedido junto ao CEP da FFCLRP-USP, solicitando a composição de um banco de dados. Elaboramos Termos de Consentimento para Composição de Banco de Dados (Apêndice G para terapeutas, e Apêndice H para clientes), os quais foram submetidos para apreciação e aprovados, mediante o atendimento de uma condição: ao fazer o convite para os participantes (tanto clientes como terapeutas), era necessário ressaltar que estes poderiam consentir em fazer parte do estudo e não autorizar a constituição do banco. Em outras palavras, a participação no estudo não ficou condicionada à concordância com o armazenamento das informações. Ademais, o banco só poderia ser constituído caso todos os participantes (clientes e terapeutas) 
concordassem - se uma das partes não consentisse, as informações não poderiam ser arquivadas.

Além disso, consultamos o CEP em relação ao pedido de Anna, de poder arquivar as informações da pesquisa como um banco de dados dela, como terapeuta. Nesta consulta, foi ressaltado o direito do participante ter acesso às informações de pesquisa que são produzidas por meio de sua participação - neste sentido, os próprios clientes podem ter acesso às mesmas, caso desejem. Assim, Anna pôde compor um banco de dados com as sessões realizadas, respondendo às exigências éticas que regulam a prática profissional do psicólogo. Elaboramos, então, uma autorização para constituição de banco de dados, seguindo as especificações do Código de Ética Profissional do Psicólogo, para que ela mantenha arquivado junto com as informações da pesquisa (Apêndice I).

Esta solicitação de mudança a partir do andamento da pesquisa, bem como a proposta de norteadores específicos para a participação da terapeuta-pesquisadora nos atendimentos, anteriormente descritos, traduzem o caráter da ética entendida como dialógica, ou seja, criada no processo de pesquisa, em decorrência das relações entre as pessoas, e de forma congruente com as necessidades e características do campo de pesquisa (McNamee, 2015).

\subsection{A construção estética do capítulo de análise e discussão}

Como indicam os procedimentos metodológicos do estudo, a redação do capítulo seguinte está embasada tanto no material construído nas sessões e nas interlocuções com as participantes, como na nossa liberdade interpretativa como pesquisadoras. Para auxiliar-nos na apresentação e discussão dos resultados, utilizamos recursos gráficos que traduzem uma sensibilidade estética para a prática científica. Embasadas em propostas pós-modernas para a construção de textos acadêmicos (por exemplo, Corradi-Webster, 2009; K. Gergen, 2009; M. Gergen \& K. Gergen, 2000), tais recursos estéticos buscam dinamizar a leitura e a compreensão do texto e dão visibilidade à alternância de vozes com as quais dialogamos. Quadros explicativos destacam informações e conceitos relevantes referentes às categorias $\mathrm{e}$ temáticas. Além disso, utilizamos diferentes recuos de texto conforme a finalidade do texto que o compõe, conforme explicamos a seguir: 
Aquilo que está escrito com recuo, letra e espaçamento no mesmo padrão adotado na tese indica textos que: (a) introduzem os assuntos a serem abordados; (b) descrevem os momentos ilustrados nos excertos de sessão; e (c) apresentam a análise no contexto da tese, abordando as inspirações para as ações das terapeutas e descrevendo recursos teóricos articulados com essas ações - tanto os recursos teóricos trazidos pelas participantes, como aqueles que nós, como pesquisadoras, articulamos com as ações em foco; por fim, (d) trazemos reflexões acerca dos efeitos que tais ações produziram no encontro terapêutico.

Os textos com recuo de $1 \mathrm{~cm}$, letra tamanho 11 e espaçamento simples, contêm trechos dos diálogos ocorridos nas sessões de atendimento. As ações que desejamos destacar encontram-se redigidas em negrito. Iniciamos cada trecho com uma breve descrição do contexto em que surge a interação em destaque.

Os textos com recuo de $5 \mathrm{~cm}$, letra tamanho 11 e espaçamento simples, contêm trechos de diálogo das interlocuções pósatendimento, as quais constituem em uma conversa sobre a conversa terapêutica. Isto é, são comentários que surgiram como fruto da análise que a pesquisadora e a terapeutaparticipante fizeram sobre suas ações no contexto do encontro terapêutico. Extrapolamos o nível da descrição das ações, para adentrarmos no nível da análise das ações pelas próprias terapeutas.

Estes distintos recuos de texto buscam representar, no texto, a alternância entre diferentes níveis que fazem parte de nossa proposta analítica. A ilustração a seguir representa estes níveis de análise e descreve os participantes envolvidos na construção de sentidos. 


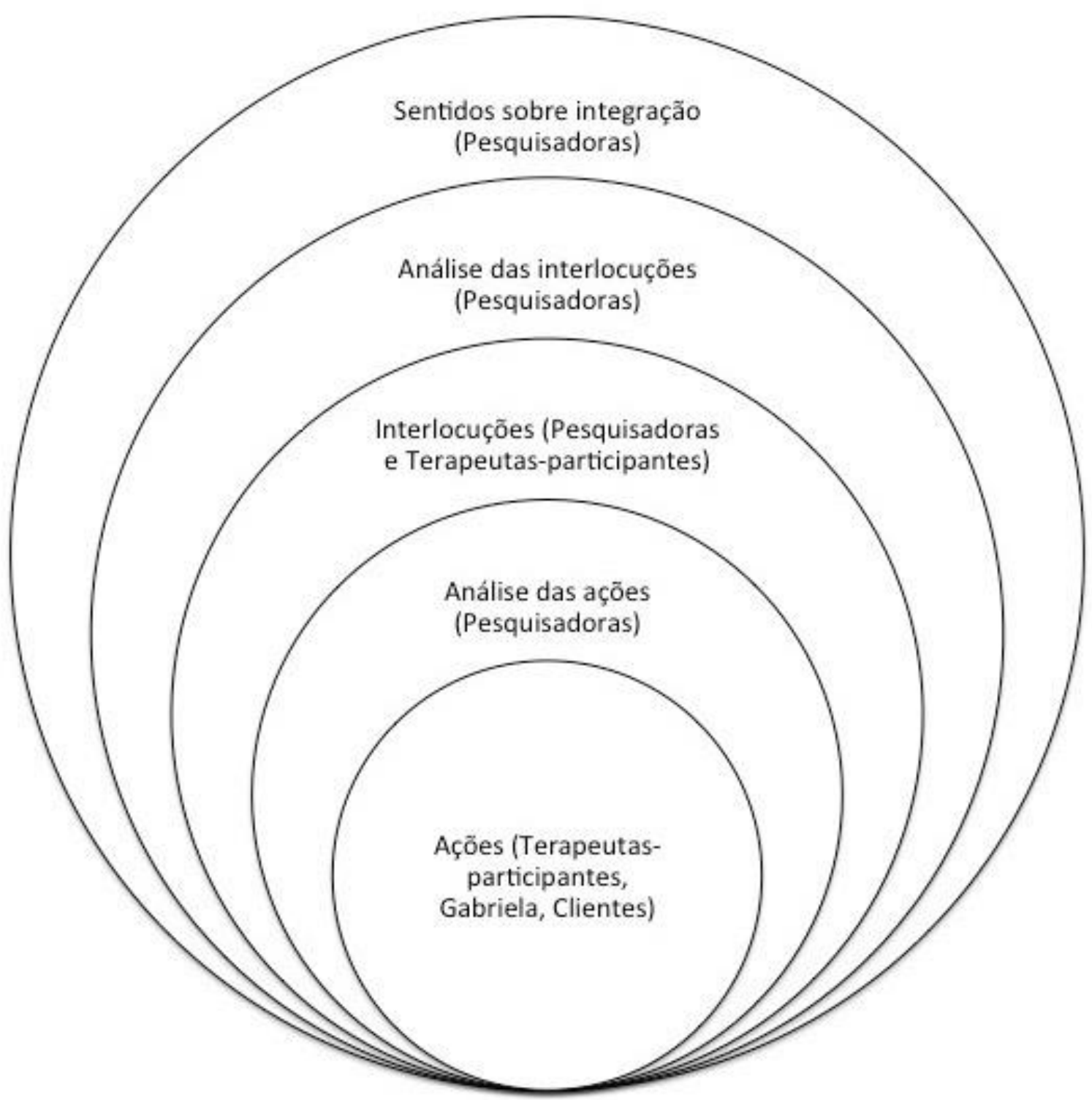

Quadro 3. Níveis de análise dos dados e participantes envolvidos. 


\section{Análise e Discussão}

Este capítulo aborda a análise dos resultados e a discussão tecida a partir da articulação com a literatura científica da área. Primeiramente, apresentamos o foco do processo analítico - as ações das terapeutas - explorando as potencialidades e limites dessa metodologia. Em seguida, descrevemos os recursos utilizados pelas terapeutas-participantes em seus atendimentos a partir das categorias criadas no processo analítico. De forma entremeada com esta discussão, apresentamos as inspirações que permeiam o uso dos diferentes recursos pelas terapeutasparticipantes, fruto das interlocuções com cada uma. Em seguida, apresentamos apontamentos que, mais diretamente, enfocam a questão da integração dos recursos teóricos e técnicos discutidos. Será, assim, um nível de análise mais global que abarca todos os níveis apresentados nas discussões do capítulo. Por fim, apresentamos as contribuições do estudo para o campo acadêmico e profissional.

\subsection{O foco nas ações}

O processo analítico dá visibilidade às ações das terapeutas-participantes nos atendimentos. Entendemos que analisar uma ação é reduzir seu sentido interpretativo, encaixando-a em uma categoria que constringe outras possibilidades de significação e, portanto, reduz sua multidimensionalidade. Além disso, "descolamos" estas ações de seu contexto para toma-las como objeto de estudo. Coerentemente com a compreensão construcionista que embasa este estudo, sabemos da impossibilidade de olhar estas ações de forma separada do contexto e das relações em que emergem, visto que é a interanimação dialógica que provê sentido à qualquer ação (M. Spink \& Medrado, 1999/2013). Todavia, ainda assim escolhemos 
utilizar o destaque das ações como uma abstração que nos permite "colocar uma lupa" sobre a prática das terapeutas e construir significados acerca das sensibilidades e inspirações que embasaram o seu fazer. A partir da descrição, interpretação e construção de justificativas para estas ações, acreditamos ser possível identificar a integração de diferentes recursos teóricos e técnicos.

Ao eleger as ações como dimensão de análise, partimos do pressuposto de que, subjacente à determinadas ações, existem inspirações em teorias e técnicas aprendidas ao longo da formação e da atuação na prática clínica. Compreendemos que é a partir do conhecimento tácito que estas ações ocorrem - sejam elas perguntas, expressões, comentários ou reflexões. Isto é, as ações surgem a partir do conhecimento criado nas especificidades da relação entre as pessoas, conhecimento esse que é corporificado e emerge de forma situada (Shotter, 2000). Assim, olhar para as ações também é olhar para o processo terapêutico - elegendo, contudo, um dos aspectos que o constituem.

Acreditamos ser evidente, a partir do foco nas ações, o risco de tomá-las como essência, ao não considerar os processos de suplementação que caracterizam a comunicação humana (K. Gergen, 2009). Ainda que este risco esteja presente, é necessário pontuar que o interesse deste estudo é o processo de construção de conhecimentos da terapeuta sobre sua própria prática. Nossa pesquisa não se propõe a analisar o processo de mudança dos clientes ou a qualidade das ações das terapeutas. Neste sentido, o fato de um cliente não suplementar uma ação da terapeuta não exclui o fato de haver uma inspiração para a ação da profissional. Um trecho do atendimento com Anna ilustra este ponto de vista:

Terapeuta Anna, Casal Luis e Ligia, Sessão 1

Anna: Você sabe, Ligia, que... vou te interromper um pouquinho, você já tinha terminado?

Ligia: Não, já.

Anna: É... É interessante falar para a gente, assim, dessa forma, porque me faz pensar que se está perdendo é porque existiu, porque alguma coisa houve, e ainda há. Porque você pôs no gerúndio, está perdendo [ênfase na entonação]. Então ainda não perdeu [sorrindo]. Então, acho que seria interessante olhar então, como é que estava, como é que era. Esse bom humor que existiu, como é que era o bom humor, então? Já vamos pensar nessa questão, que me deixou curiosa, aí. Que bom humor é esse que então houve. Fazia parte da relação de vocês?

[breve pausa]

Ligia: Fala Lu.

Luis: Fala você. 
Ligia: Eu não, fala você um pouco...

Luis: [tosse]

Ligia: ...porque eu também estou aqui para te ouvir. É... Nossa discussão é essa [falando com terapeuta], porque eu falo... Então dá a impressão que eu estou falando demais, que ele não tem paciência de me ouvir. Quando eu começo a falar assim, nosso papo logo acaba.

Anna: E aí, Luis?

Luis: Não, eu acho que....

Anna: A sensação dela é a sensação que você tem?

Neste trecho, Anna faz uma colocação que ilumina aspectos passados da relação, que parecem ainda estar presentes nos dias atuais. Pergunta, assim, como o bom humor se presentificava na relação do casal antes do surgimento dos conflitos. $\mathrm{Na}$ sequência, diante da dificuldade do casal em definir quem irá responder à pergunta, Ligia pontua que estas dificuldades são parte da comunicação do casal. Assim, Anna muda o direcionamento da conversa, passando a abordar a questão da comunicação, a qual segue como tema da conversa entre nós.

O trecho ilustra que, em certos momentos do processo terapêutico, as ações de Anna (comentários, perguntas, reflexões) são suplementadas de tal forma que o direcionamento proposto - no caso, falar sobre o bom humor que existia - perde seu efeito como um tema a ser conversado. Os clientes oferecem outro caminho para o diálogo e a terapeuta segue nas direções propostas pelos clientes, abandonando o caminho de investigação anteriormente oferecido por ela. O que ressaltamos é que, ainda que a pergunta sobre o bom humor perca seu efeito como tópico de conversa, ela esteve presente no diálogo e surgiu, presumivelmente, a partir de uma inspiração ou objetivo por parte de Anna. Desse modo, para a análise de nosso estudo, faz-se necessário destacar esta pergunta como relevante mesmo que não tenha feito parte da conversa que se segue.

As ações das terapeutas (tanto participantes quanto pesquisadora) foram divididas nas seguintes categorias: ações exploratórias, ações de construção de visões relacionais, ações de construção da comunicação em contexto e ações de orientação familiar. Além destas, a análise do material também nos sugeriu a construção de outras duas categorias que não farão parte desta discussão: ações de acolhimento (que oferecem pistas sobre a interação social que ocorria no momento); e ações de estruturação de contexto (que constituem mais marcadamente algumas especificidades da prática clínica, como o agendamento de horários, por exemplo). Consideramos relevantes todas estas categorias, todavia, as quatro primeiras dão 
mais indícios do uso de recursos teórico-técnicos que nos ajudam a responder o objetivo do estudo e por isso foram selecionadas.

\subsection{Ações em contexto: os recursos utilizados pelas terapeutas}

Nesta seção, apresentamos a definição das categorias analisadas e suas respectivas temáticas, exemplificando cada uma delas com trechos de sessões. O quadro 4 apresenta a definição das categorias.

\section{Categorias}

Ações exploratórias

Ações de construção de visões relacionais

Ações de construção da comunicação em contexto

Ações de orientação familiar

\section{Definição}

Constroem conhecimentos que orientam a terapeuta e a família. Convidam os membros a trazerem informações, descrições e discursos sobre eles mesmos ou outras pessoas.

Ampliam sentidos sobre os problemas, as pessoas e as possibilidades de mudança. Tornam mais complexas e relacionais as descrições sobre si e sobre o outro. Iluminam novos caminhos nas possibilidades do que os membros podem conhecer, sentir e fazer.

Ações voltadas para a construção do contexto conversacional, e que podem trazer reflexões sobre os efeitos da comunicação desenvolvida na terapia.

Ações que intervêm mais diretamente sobre o problema trazido pela família e surgem quando a terapeuta age a partir de um lugar de especialista.

Quadro 4. Definição das categorias analisadas.

Como pode ser observado, as ações surgem em contexto, ou seja, de forma situada, e são recursos para a comunicação, criação e manutenção das relações entre os participantes do processo terapêutico.

Um aspecto que vale a pena ser ressaltado envolve a questão da análise das ações da pesquisadora-terapeuta (Gabriela) no âmbito dessa pesquisa. Embora tais ações tenham sido categorizadas na etapa 5 do método, elas não fizeram parte das 
etapas de análise subsequentes. Isto porque analisar as ações da pesquisadoraterapeuta demandaria a criação de um espaço de interlocução de Gabriela com ela mesma, em busca de nomear as inspirações para suas ações. Embora isso enriqueça ainda mais os dados e o caráter de pesquisa-ação do estudo, também aumenta sobremaneira a complexidade e quantidade de material a ser analisado. Desse modo, optamos por fazê-lo apenas em relação às ações das terapeutas-participantes, acreditando que este delineia um limite do estudo.

\subsubsection{Categoria: Ações exploratórias}

Estas ações estão voltada para a exploração de diferentes temas por parte das terapeutas.

\begin{tabular}{lll}
\hline \multicolumn{1}{c|}{ Categoria } & \multicolumn{1}{c}{ Temáticas } & Terapeuta \\
$\begin{array}{l}\text { Ações } \\
\text { exploratórias }\end{array}$ & $\begin{array}{l}\text { Fazer perguntas de exploração (história do casal, } \\
\text { história do problema, sentimentos, desejos, } \\
\text { preferências, etc.) }\end{array}$ & Anna e Lina \\
& $\begin{array}{l}\text { Explorar o sentido considerando a expressão não- } \\
\text { verbal }\end{array}$ & Lina \\
& $\begin{array}{l}\text { Investigar a rede social e familiar } \\
\text { Fazer comentários e perguntas apreciativas }\end{array}$ & Anna \\
& $\begin{array}{l}\text { Explorar sentimentos ou intenções que movem } \\
\text { ações }\end{array}$ & Lina \\
& Explorar a exceção do problema & Anna e Lina \\
& Explorar recursos para a superação do problema & Anna \\
& Explorar o genograma & Lina
\end{tabular}

Quadro 5. Temáticas que compõem a categoria “Ações exploratórias" 


\section{a. Temática: Fazer perguntas de exploração}

Estas perguntas buscam informações que orientam tanto terapeutas quanto a família - investigam a história do casal ou família (como se conheceram, casamento, nascimento e infância dos filhos, etc.), a história do problema (o que cada um considera como sendo o problema que levou à terapia, quando começou, quais são os efeitos na vida de cada um, etc.), além de explorar os desejos, sentimentos, preferências de cada um.

As perguntas de exploração podem estar voltadas para a necessidade da terapeuta conhecer a família, ou podem visar a construção de sentidos potencialmente transformadores para a família na medida em que exploram as vivências em um novo contexto e com uma finalidade terapêutica. A seguir, indicamos trechos de sessões que exemplificam essa temática.

Terapeuta Lina, Família Silva, Sessão 3

A sessão estava quase no fim, e havíamos passado um tempo conversando com Renata e Amanda sobre as preocupações e necessidades da mãe em relação às saídas da filha à noite com os amigos. Então, voltando-se para Raul, Lina pergunta:

Lina: Você tem essa preocupação também, Raul? Ou a sua é diferente?

Raul: Eu tenho. Eu acho que as coisas que avisar tem que avisar mesmo, porque acho que é o mínimo. Eu acho que é, tipo, uma obrigação que tem.

Terapeuta Anna, Casal Luis e Ligia, Sessão 2

Conversávamos sobre a época do namoro e a ideia que eles tinham sobre o casamento quando resolveram se casar.

Anna: Eu ainda estou pensando, né? Que tinha uma ideia do que seria um casamento, provavelmente, quando vocês namoraram. Qual é a ideia que vocês tinham? $E$ aí eu quero ouvir separadamente cada um de vocês. Lá na época do namoro, dessa ida e vinda, qual era a ideia do casamento, como é que surgiu o desejo do casamento, o plano do casamento? Quem quer falar primeiro?

No excerto do atendimento de Lina, o foco da exploração são as preocupações de Raul no tocante às questões com a filha, Amanda. No trecho de Anna, a terapeuta investigava os sentidos que o casal atribuía ao casamento quando escolheram ficar noivos. Anna e eu conversamos sobre esta categoria em nossa interlocução: 
Anna: Então é o passeio de helicóptero, isso é outra metáfora que a Harlene Anderson usa, é um passeio de helicóptero e os clientes vão te mostrando as coisas que eles gostam, a vida deles. E aí você fala: "ah, então eu vou ficar curiosa por aqui, o que tem por aqui?”. Entende?

Gabriela: Unhun.

Anna: Então, isso também está dentro da colaborativa, do que a Harlene fala. [...]

Gabriela: Quando você está aqui na exploração, no acolhimento, no cuidado, parece que você vai se conectando bastante com essa questão da colaborativa. Aí você trouxe do helicóptero, ou seja, por onde a gente vai ver tudo o que eles estão nos mostrando, né? Você vai explorando, você vai conhecendo, você é a convidada, né? A hóspede.

Anna: É.

Anna enfatiza que suas perguntas de exploração são marcadamente influenciadas pelas propostas de Harlene Anderson. Para a participante, esta é uma inspiração que lhe ajuda a ficar conectada com o que os clientes consideram como sendo importante para eles, destituindo-lhe de intenções a priori sobre o que deva ser o foco da exploração da terapeuta. Anderson (2016) utiliza a metáfora do hóspede e do anfitrião como uma imagem para a investigação mútua que consiste a postura do terapeuta colaborativo: ao mesmo tempo em que é um anfitrião para os clientes que lhe procuram, o terapeuta também é um hóspede em suas vidas e deve sê-lo a partir de uma postura de genuína abertura para conhecer o outro a partir de seus próprios termos. Na proposta colaborativa, entende-se que a construção de mudanças surge a partir de diálogos colaborativos, nos quais a exploração das questões trazidas pelos clientes pode gerar ampliações e redescrições (Anderson, 2016; Anderson \& Gehart, 2007; Anderson \& Goolishian, 1992). Quando tomadas neste sentido, as perguntas de exploração articulam-se com a proposta colaborativa, e possuem uma intenção de provocar mudanças nos clientes por meio do desenvolvimento de novos conhecimentos, em uma conversa estruturada a partir da lógica dos clientes e do que eles consideram como sendo relevante para os problemas em questão.

Em outros momentos, as perguntas de exploração podem estar voltadas para a necessidade da terapeuta conhecer mais as pessoas e as problemas trazidos para a terapia. No excerto da sessão com Lina, acima, a terapeuta busca compreender como cada pessoa está compreendendo o problema, na tentativa de orientar-se em relação 
às ideias e necessidades de cada um em relação à terapia. Quando tomadas neste sentido, as perguntas de exploração tendem a convidar as pessoas a trazerem informações que já são conhecidas por elas, delineando um "recontar de histórias" que, muitas vezes, faz surgir a repetição de conversas e versões que são comuns em suas vidas cotidianas. Neste caso, as ações estão mais voltadas para a necessidade da terapeuta conhecer os clientes e o que eles pensam, possibilitando a construção de um vocabulário comum e o estabelecimento de uma aliança à medida que a terapeuta vai sendo inserida nas imagens, paradigmas, dramas e símbolos familiares. Nesta acepção, as perguntas de exploração podem ser relacionadas ao que Tomm (1988) denomina como perguntas lineares, as quais possuem uma intenção investigativa por parte do terapeuta, que busca criar um mapa sobre os eventos ocorridos ao longo do tempo. Para o autor, as perguntas lineares costumam ocasionar um efeito conservador, no sentido em que não geram novas informações mas sim convidam à construção de versões sob uma lógica de causa-efeito, em que o foco é definir e explicar o problema que levou os clientes à terapia.

\section{b. Temática: Explorar o sentido levando em consideração a expressão não-verbal}

Esta temática descreve ações de Lina voltadas para mais de uma dimensão da comunicação, como exemplifica o trecho a seguir.

Terapeuta Lina, Casal Motta, Sessão 1

Estávamos próximos ao final da sessão, e após ouvir cada um nos contar sobre a história da relação, Lina e eu propomos que falássemos um pouco das emoções que vimos surgir em ambos enquanto traziam estas histórias. Voltando-se para Vivian, Lina retoma o momento em que ela nos contou sobre sua mãe.

Lina: Vivi, você, quando foi falar da sua mãe [Vivian começa a chorar, Gabriela entrega lenços de papel], aquela emoção que veio aquela hora é a mesma que está vindo nesse momento?

Vivian: É.

Lina: Que nome você dá para essa emoção?

Vivian: [breve pausa] A emoção não é uma só.

Lina: Anhan. Pode dar vários nomes.

Vivian: Pode? Tristeza. Pena.

Lina: Pena de quem?

Vivian: Da minha mãe. 


\section{Lina: E da menina que ficou sem mãe também?}

Vivian: Também.

Este trecho ilustra a busca pela construção de sentidos que integram as dimensões daquilo que é dito e do que acompanha o proferimento - emoções, gestos, expressões e posturas corporais, inflexão de voz. Para além do que os clientes nos contam, nos interessamos pelas emoções que acompanharam o que foi dito e que aparecem por meio da linguagem não-verbal.

Sluzki (2016) descreve os diferentes níveis da linguagem, afirmando que o sentido é construído a partir de trocas que envolvem as dimensões: linguísticas verbais (aquilo que é dito), verbais extralinguísticas (tom, ênfase, inclinação de voz), não verbais (gestos, postura, proxêmica), sinais e pistas contextuais. Assim, nossas conversas acontecem como troca de mensagens que excedem o nível das palavras proferidas. $\mathrm{O}$ autor ainda enfatiza que, por sua riqueza e pela grande quantidade de informações que carrega, o nível linguístico-verbal costuma ser o maior foco de nossa atenção, ainda que os demais componentes sejam extremamente importantes para dar sentido ao que foi dito (Sluzki, 2016).

Lina, além de observar esta dimensão não-verbal da linguagem, traz estes elementos para a conversa em curso, incluindo o cliente no processo de atribuição de sentidos aos fatores não-verbais. Estas explorações permitem à terapeuta construir, com os clientes, conhecimentos acerca de como estes se orientam (ou se orientaram no passado) diante das experiências vividas.

\section{c. Temática: Investigar a rede social e familiar}

Estas ações consistem na exploração das pessoas significativas que compõem a rede social e familiar dos clientes.

Terapeuta Anna, Casal Luis e Ligia, Sessão 3

Já estávamos no final da sessão. Luis traz novamente preocupações em relação ao envelhecer e ficarem sozinhos, apenas ele e Ligia, pois "todos na família já são velhos". Neste momento, Anna indaga sobre as suas sobrinhas, que ele havia mencionado há pouco na sessão. Luis diz que elas são moram em outra cidade e "cada um vive sua vida”. 
Anna: Vocês têm momentos em que vocês se reúnem a família toda?

Ligia [olhando para Luis]: Tem, né?

Luis: Mais feriado.

Anna: Com que frequência que vocês se encontram com as meninas, as sobrinhas?

Luis: Agora menos, antes encontrava mais.

Anna: O que que houve? O que mudou?

Via de regra, Luis trazia preocupações quanto ao envelhecimento do casal. Trazia-lhe certa inquietação e angústia o fato de não terem filhos e fazerem parte de uma família cujas gerações mais numerosas eram aquelas com a mesma idade ou mais velhas do que eles. Ao longo do processo, percebemos também a importância que o cachorro de estimação Tom tinha na vida do casal. Eles o descreviam como um "companheiro" e diziam que "nunca ficavam sozinhos" devido à presença de Tom em suas vidas. O lugar de Tom como um membro da família ficou ainda mais evidente quando o casal cogitou uma possível separação, surgindo conversas angustiantes sobre quem ficaria com o cachorro caso eles decidissem se divorciar.

Sobre o uso deste recurso, Anna comenta:

Gabriela: E aí quando você investiga a rede social e familiar, eu inevitavelmente penso no Sluzki, que eu não sei se é nele que você pensa quando faz esse tipo de pergunta.

Anna: Sim. [...] Mas eu acho que entra também uma ideia, ou um conceito da questão do self dialógico, do quem sou eu, como eu sou hoje, que outras relações eu estou envolvida, no sentido de conhecer. Por exemplo, o Luis, então: "com quem ele conversa? Como ele conversa?”. Porque eu estou conhecendo o Luis ali naquela cadeirinha, naquela poltroninha, naquele momento. Mas ele também... tem muitas outras possibilidades, muitos outros Luis, digamos assim. Então: "E também com quem ele conversa? Como é que ele conversa? Como são essas pessoas?”. Talvez me trazer um pouco mais de informação e [...] outras vozes e conhecê-lo também em outros lugares, em outras relações. Um pouco assim. 
Ao definir o self a partir de uma perspectiva dialógica ${ }^{6}, \mathrm{~K}$. Gergen $(2008,2009)$ afirma que o encontro entre terapeuta e clientes é o encontro entre as múltiplas vozes que compõem cada um deles, trazendo as diversas relações em que cada pessoa está envolvida. A partir desta concepção, os indivíduos são fundamentalmente interligados e toda ação humana deve ser compreendida a partir deste entendimento relacional. Uma prática clínica sensível a estes pressupostos implica na exploração das diferentes pessoas e vozes a partir das quais os clientes vão construindo suas identidades e compondo suas vivências cotidianas (K. Gergen, 2008). Sensível a estes pressupostos, Anna dirige-se para a exploração dos outros Luis e das demais relações nas quais ele está imerso e as possibilidades que emergem a partir daí.

Uma outra inspiração para estas ações foi a proposta de Sluzki (1997). Para o autor, as fronteiras de um indivíduo são delimitadas não por sua pele, mas por tudo aquilo com que a pessoa interage - família e demais vínculos interpessoais, contextos culturais, históricos, políticos, econômicos, religiosos, do meio ambiente, relação com os serviços públicos. O autor afirma que a implicação deste nível de análise para a prática terapêutica é que a exploração da rede social de uma pessoa, casal ou família acaba por torna-la visível para todos, e nomeá-la é o primeiro passo para utilizá-la terapeuticamente.

A partir de explorações sobre a rede social do casal, delineamos orientadores para o manejo clínico deste atendimento ao longo de toda a sua duração. A questão da ampliação da rede social de Luis e Ligia como indivíduos e como casal passou a ser parte importante do processo terapêutico. Foi ficando evidente que ambos viviam em um isolamento social que nos preocupava - o fato de não terem relações de maior intimidade ou proximidade com qualquer amigo ou familiar parecia ampliar a dimensão que os problemas conjugais assumiam em suas vidas. Qualquer pequeno acontecimento desagradável trazia um alto nível de estresse para ambos, e o fato de ficarem sempre em casa e sozinhos parecia elevar esta tensão e o desconforto, trazendo mais impasses e dificuldades na superação dos conflitos.

Desse modo, fomos dando mais ênfase em explorações sobre as pessoas com quem eles poderiam viver mais proximamente e construir laços de amizade, intimidade e carinho. Encorajamos encontros com amigos do trabalho de Ligia (pois

\footnotetext{
${ }^{6} \mathrm{O}$ termo self dialógico é utilizado por diferentes autores que discutem a construção relacional do indivíduo. Em nossa análise, priorizamos a definição de Kenneth Gergen por ser um autor citado por Anna em nossas conversas pós-sessão e na interlocução pós-atendimento.
} 
Luis ficou desempregado durante todo o período da terapia) e momentos de lazer com a família de cada um deles.

\section{d. Temática: Fazer comentários e perguntas apreciativas}

Os comentários e perguntas apreciativas exploram elementos de força, competência, positividade, união, mudança em direções desejadas, empenho, e outros aspectos que parecem aproximar os clientes daquilo que eles desejam ser ou que os conectam com formas de ser que podem ser mais potentes para alcançarem a mudança desejada.

Terapeuta Anna, Casal Luis e Ligia, Sessão 4

Estávamos no final da sessão, e Anna faz um comentário que destaca aspectos conversados naquele dia, mas também em sessões anteriores:

Anna: Você fica curioso de "feedback", né? [falando com Luis] Fica curioso de ouvir o que a gente [terapeutas] está pensando, o que a gente tem pensado, tem conversado, assim. Uma das coisas que chama nossa atenção é o quanto vocês estão juntos, né? Essa sintonia, como a gente está falando. Outro dia a Gabriela falou da cumplicidade, né? Do quanto vocês têm de intimidade. É interessante isso, chama a atenção da gente porque não é um casal que, assim, às vezes um está falando de pedra e o outro está falando de água. Um está buscando pedra e o outro está buscando água. [...] Por isso eu usei a imagem do túnel, parece que vocês estão no mesmo túnel, buscando a mesma luz no fim do túnel, não são túneis diferentes, sabe? Mais ou menos isso. E isso é, assim... puxa gente, se isso não é um casal, o que é um casal, então?

[risos de Ligia e Gabriela]

Ligia: É, então.

Luis: Por quê? Você já atendeu casal que ela estava na Lua e ele estava em Júpiter?

Anna: Sim. Até nas queixas, até nas dificuldades. Vocês, até os pedidos, para onde vocês querem olhar, o que vocês querem conversar aqui, é muito em sintonia vocês dois. Se era isso que você queria ouvir, do que a gente tem observado, né Gabriela? Acho que isso é muito.

Luis: Alguma coisa de boa tem que pegar dessa união, né?

Ligia: Eu acho que a gente tem muita coisa boa, senão eu não me sentiria bem em estar do lado dele, de sentir saudade dele enquanto eu estou longe, apesar de não passar mensagem [pelo Whatsapp] [risos].

Anna [falando para Luis]: Olha o que você está ouvindo! [risos]

[todos riem]

Luis: É...

Anna: Você já tinha ouvido isso antes? Que ela sente saudades de você! [...] é tão gostoso ouvir falar que tem saudades, né? Fala sério. Tem saudades um do outro, gente. Que bom! Sabia que quando a gente sente saudades é porque foi bom, é algo que a gente teve e foi gostoso? A gente sente 
saudade de uma coisa que a gente gosta, que a gente quer, que foi bom, está sendo bom.

Terapeuta Lina, Casal Motta, Sessão 7

Lina inicia a sessão fazendo este comentário que retoma questões conversadas nas sessões anteriores.

Lina: Eu tenho sentido, percebido, escutado de vocês... porque a gente está em uma conversa difícil, coisas que doem, que dão canseira, às vezes alívio, às vezes medo, revolvem mágoas. Mas ao mesmo tempo vem me chamando a atenção o quanto vocês têm ficado empenhados nesse nosso trabalho, o quanto se empenham e se escutarem, mesmo naqueles momentos em que o outro está dizendo coisas difíceis de ouvir.

Gabriela: Unhun.

Lina: Então isso chama a atenção da gente, e eu acho que posso falar por nós, né Gabi?

Gabriela: Sim, sim.

Lina: Do que parece que, apesar da dificuldade, parece que é importante para vocês estarem aqui. Vocês põem um empenho nisso. É assim que vocês percebem também?

É importante destacar que estas perguntas e comentários eram realizados em tom genuíno e sincero, distanciando-se de uma ação que pareça ingênua ou que posicione o outro de forma infantilizada. Às vezes, vinham permeadas por um tom de humor, como o último comentário de Anna no trecho apresentado.

A investigação apreciativa consiste em uma exploração voltada para as potencialidades das pessoas, enfatizando sucessos passados e presentes que possam abrir espaço para novas possibilidades (Cooperrider, Whitney \& Stravros, 2003). Articulando-a com a prática clínica, Souza, McNamee e Santos (2010) afirmam que fazer perguntas sobre potenciais, sucessos, desejos e planos futuros convida os clientes a elaborarem e expandirem possibilidades de conversa ancoradas nestes parâmetros.

Nos atendimentos com Anna e Lina, as explorações com enfoque apreciativo pareciam ser uma inspiração em momentos específicos - quando o ambiente de tensão e dificuldades parecia esmorecer as esperanças de mudança; quando os discursos sobre as dificuldades e problemas prevaleciam, parecendo minar qualquer possibilidade de ser e estar diferentemente nas relações; quando a família mostrava engajamento e persistência em uma conversa difícil, sobre tópicos angustiantes, em busca de um novo entendimento. 


\section{e. Temática: Explorar sentimentos e intenções que movem ações}

Estas explorações levam a conversa para dimensões que estão além das ações concretamente observadas pelas pessoas, buscam o que está por trás delas.

Terapeuta Lina, Família Silva, Sessão 2

Lina explorava com Raul algumas questões relativas aos conflitos entre ele e Amanda, e o pai mencionava quais são as coisas que deseja para a filha (e que, para ela, parecem que são uma forma dele "pegar no seu pé").

Raul: Tudo o que eu faço, eu só quero dar o melhor para ela, entendeu? [...] eu quero que ela fique bem. Eu nunca fui de estudar, mas não é porque eu não estudei que eu não quero que ela estude também. Então, se formar, fazer alguma coisa, ser uma pessoa independente, entendeu? Então eu quero ela encaminhada. Isso que eu queria.

Lina: De onde vem esse seu desejo de vê-la bem, de ver o melhor para ela?

Raul: Todos os pais querem o melhor pros filhos, não é?

Lina: Não sei, parece que você quer, né?

Raul [rindo]: Eu quero. [...]

Lina: Raul, desculpa. Eu fiquei interessada porque isso também me chamou a atenção, de você... porque parece que vocês desejam coisas muito boas uns para os outros. $\mathrm{E}$ vocês falam que "toda mãe e todo pai". Eu não sei se toda mãe e todo pai, mas eu estou vendo que vocês realmente têm uma preocupação grande em relação à isso.

Raul: Sim.

Lina: E desculpa, mas na minha crença [rindo], não nasce esse desejo meramente porque um filho nasce. Então eu fico muito curiosa para saber o que tem nessa filha específica que faz vocês quererem ela tão bem [...] Você falou que não estudou mas quer ver ela estudando?

Raul: Na minha família eu fui o único que não estudei. Porque eu parei, mas meus irmãos são todos formados. Meus familiares da parte do pai também são todos formados.

Lina: Parece, se eu estou entendendo bem, algo que você escolheu e que para você não deu muito certo, você não gostou de ter escolhido aquele caminho, você gostaria que ela escolhesse outro.

Raul: Eu queria que ela escolhesse uma parte boa que eu não consegui.

Lina: Eu ainda fico com vontade de encontrar um nome para esse sentimento que faz você produzir estes desejos, né? Se vier na sua cabeça a ideia de onde... qual sentimento que faz você querer estas coisas para ela, ainda que você tenha escolhido, em algum momento lá atrás, coisas diferentes para você. Porque eu acho muito nobre você desejar para outras pessoas coisas, às vezes, que você nem lembrou de desejar para você mesmo.

Deslocar o foco das ações para os sentimentos e emoções pode convidar os membros também a deslocarem sua atenção dos comportamentos que são 
considerados irritantes e "pegação no pé” para as intenções, desejos e vivências que inspiram os comportamentos e muito raramente são expressos como a força motriz daquilo se faz.

Esta exploração feita com Raul culmina em um comentário muito tocante, que Lina traz de forma genuína e emocionada, sobre os desejos que o pai nutre em relação ao futuro da filha e que, no passado, não faziam parte das coisas que ele desejou para si mesmo. Atualmente, desempregado e com dificuldades para inserirse novamente no mercado de trabalho, Raul insiste para que a filha dedique-se à sua educação e formação profissional.

$\mathrm{Na}$ interlocução com Lina, ela afirma embasar as explorações dos sentimentos e intenções que movem determinadas ações na ideia de conversas de construção de andaimes de Michael White (White, 2012). O excerto de conversa com Raul parece trazer dois aspectos das conversas de construção de andaimes - em um primeiro nível, Lina convida Raul a nomear os sentimentos que produzem este sincero desejo de dar o melhor para a filha, o que poderia ser uma ação identificada como tarefa de distanciamento de nível baixo, em que o terapeuta estimula a atribuição de significados para acontecimentos ainda não nomeados ou identificados. Em um segundo nível, Lina faz correlações entre as vivências passadas de Raul em sua família de origem e os desejos que ele têm de oferecer o melhor para sua filha no tempo presente, tendo em vista seu futuro. Esta articulação de vivências pode ser entendida como uma tarefa de distanciamento de nível médio, em que o terapeuta acompanha as pessoas no estabelecimento de conexões entre acontecimentos. Como efeito destas ações de construção de andaimes com Raul, vemos que a exploração dos sentimentos que o movem proporciona um momento em que a família pode explicitamente conversar sobre critérios e parâmetros que movem suas ações a partir de uma espécie de deslocamento no nível conversacional: dos comportamentos e ações concretas para as linhas invisíveis que tecem os relacionamentos. Este foco inusitado pode trazer novas possibilidades para a família alinhavar seus entendimentos e buscar outras formas de relação. 


\section{f. Temática: Explorar a exceção do problema}

Esta ação consiste em realçar uma exceção do problema por meio da exploração de alguns aspectos que surgem na conversa - por exemplo, uma vivência única e especial ou uma forma de agir que foge ao que é tomado como esperado e "natural".

Terapeuta Lina, Casal Motta, Sessão 10

O enfoque em descrever a exceção do problema permeia toda esta sessão. Logo no início, aparece uma narrativa, por parte do casal, de algo diferente e positivo que lhes aconteceu no final de semana. Ao explorarmos e buscarmos mais detalhes e elementos acerca do ocorrido, o casal passava a relembrar brigas e conflitos do passado, iniciando interações tensas e conflituosas entre si. Esta oscilação aconteceu diversas vezes durante a sessão, e por isso os momentos de busca pela exceção do problema acontecem no início, no meio e no término do atendimento.

Lina: [falando com Vivian] Parece que você está contando sobre duas pessoas que parece que fizeram coisas diferentes. De um lado, o Igor, que não gostou de você ficar ligando e não-sei-o-quê, e que te contou: "olha, não gostei, não precisa". E uma outra pessoa que fez coisas diferentes, que foi a Vivian, que ao ouvir o marido dizer: "olha, não gostei de você ficar ligando, não é necessário, tal”, pôde reconhecer que de fato não é necessário, que tem a ver com coisas anteriores e que não precisaria. Então, duas pessoas fizeram diferente, e algo que parece que produziu um bom resultado.

Vivian: Unhun. Unhun. Foi o que eu percebi.

Lina: Para você isso fez diferença também, Igor?

Igor: Eu sinto que tudo, é tipo assim, tá, é complicado, é difícil a gente não trazer o passado para o presente, mas tenta pelo menos evitar um pouco isso aí, né?

A partir deste momento, o casal passa a abordar questões do passado, com interações conflituosas. Igor e Vivian discutem a partir de visões distintas. Quando surge uma abertura, Lina volta a explorar o ocorrido no final de semana:

Igor: [...] E eu pensei: "vai chegar em casa e vai quebrar o pau”. E eu não estava fazendo absolutamente nada.

Lina: E aconteceu isso de chegar em casa e quebrar o pau?

Igor: Não, eu fui cobrar a situação: "por que você está me ligando?”.

Lina: E aconteceu o quebra pau?

Igor: Teve uma discussão. Teve uma discussão.

Lina: Que foi como costuma ser?

Igor: Não.

Lina: Então houve uma mudança.

Igor: Houve Lina, mas eu acredito que essa mudança poderia ser... esse assunto poderia ser totalmente diferente. Totalmente avesso do que foi, entendeu?

Igor reforça estas ideias de que acha que este assunto já deveria estar "encerrado" entre eles. Lina e eu começamos uma conversa entre nós - Lina destaca que estava com uma sensação de que havia um pedido de deixar o passado para trás, e neste final de semana eles conseguiram isso. Todavia, quando passamos a olhar para isso, ambos começam a trazer este passado novamente e falar coisas que machucam um ao outro. Eu destaco que parece que a expectativa de uma grande mudança pode ofuscar o fato de já estarem 
havendo pequenas "mudancinhas", as quais, ao longo do tempo, darão forma à grande mudança que desejam. Quando passamos a conversar com eles, uma nova interação conflituosa se inicia, e eles retomam questões do passado. Ambas as terapeutas fazem diversas interrupções e tentativas de retomar uma conversa menos hostil, mas as interações seguem tensas. Em determinado momento, Igor faz um pedido para Vivian: pede reciprocidade em relação às coisas que ela exige dele - se quer exigir certos comportamentos, ela também deve se comportar em conformidade com o que pede.

Lina: Você está pedindo reciprocidade.

Igor [falando com Vivian]: Exatamente. Quando eu estiver falando com você, você para de fazer o que está fazendo e presta atenção no que eu estou falando, porque é isso que ela quer. Para mim não vai ser difícil parar para escutar.

Vivian [falando com Igor]: É sim.

Igor: Mas nem começou, gente! [...]

Lina: Você está se propondo a parar e ouvi-la, e olhar para ela enquanto ela fala.

Igor: Exatamente. [...]

Lina: Você está propondo o jogo agora.

Gabriela: E eu entendi, olha, de novo uma coisa nova aparecendo, né? Eles fazendo pedidos um para o outro...

Igor: Não, mas...

Lina: A Vivi fez um também hoje.

Gabriela: A Vivi fez um.

Igor: Não, mas eu estou...

Gabriela: Não, é muito bacana, estou apontando como algo interessante.

Igor: Não, mas eu estou trazendo isso agora, porque veio agora.

Gabriela: Anhan. Anhan. Você acabou de pensar nisso.

Igor: Aí já chegou e deu atrito: “ah, mas você não faz!”. Peraí, que horas que eu não fiz? Vivian [falando com Igor]: Eu não achei que você estava propondo para começar a fazer. [...]

Gabriela: Sabe uma coisa interessante que eu percebi? Que hoje, nestas duas vezes que vocês fizeram estes pedidos, vocês conversaram entre vocês. $E$ isso foi uma diferença também, porque em geral nessas conversas e pedidos, era vocês falando com a gente, né? A Vivi fala com a gente, a gente fazia o pedido para o Igor e vice-versa. E hoje vocês conversaram. E eu acho... vocês se reconhecem nessa mudança? De um casal que está conversando mais e... criando aí ferramentas para fazerem pedidos um para o outro sem ajuda?

Vivian: Sim. Devagar.

Igor: Acho que o que é feito com rapidez o negócio sai complicado.

Terapeuta Anna, Casal Luis e Ligia, Sessão 3

Ligia descrevia diversas questões problemáticas do casal, articulando-as em torno do desemprego de Luis. Anna, então, volta-se para Luis, indagando como ele vê os assuntos que estão sendo abordados.

Anna [falando com Luis]: O que mais você foi pensando em relação aqui, à nossa conversa?

Luis: Não, que a Ligia está correta no que ela falou. A nossa vida está bem assim hoje, bem... não vou dizer complicada, né? Porque nós temos... eu e a Ligia temos muitos momentos bons...

Anna: Uhn?

Luis: ... momentos de paz, né? Mas está assim. Está complicado, né? 
Anna: Então, conta um pouquinho, agora fiquei curiosa. Como é que são esses momentos de paz que vocês têm? Descreve um pouquinho para a gente imaginar, né? [olhando para Gabriela]

Gabriela: Unhun.

Anna: Como é que são esses momentos de paz, que você está chamando?

Ainda que, na interlocução com as terapeutas, não tenhamos produzido sentidos especificamente sobre esta temática, a exploração da exceção do problema é uma ação que parece se aproximar das ações voltadas para um enfoque apreciativo, anteriormente discutidas, no sentido em que as terapeutas iluminam aspectos mais positivos das relações e ações das pessoas (Souza, McNamee \& Santos, 2010). Além disso, a busca pela exceção do problema ressalta, também: mudanças que têm ocorrido na vida da família (sobretudo aquelas relativas aos problemas que os trouxeram para a terapia); e narrativas que parecem estar à margem do problema ou, como propõe White (2012), narrativas que fogem às histórias dominantes, enfocando acontecimentos singulares e iluminando versões mais libertadoras e com caráter empoderador das pessoas e relações.

\section{g. Temática: Explorar recursos para a superação do problema}

A exploração dos recursos para a superação do problema consiste em ações que tanto estiveram voltadas para os recursos que já faziam parte da história das pessoas com seus problemas (como ilustra o trecho abaixo), como focaram no que as pessoas ainda não haviam tentado mas sentiam que poderia ajudar no enfrentamento das situações geradoras de sofrimento.

Terapeuta Anna, Casal Luis e Ligia, Sessão 2

Ligia, chorando, nos contava sobre como descobriu a infidelidade de Luis, e as razões pelas quais resolveu ficar com ele. Quando Anna a pergunta sobre os recursos que a ajudam a lidar com a situação, Ligia para de chorar, mas ainda responde com a voz trêmula.

Ligia: Quando eu decidi ficar com ele, é como se você tivesse comido uma coisa indigesta, que tem que ser... tem que ir tomando os remédios para ir digerindo o que está entalado aqui. Demorou, viu? Demorou.

Anna: O que que foram os remédios que estão te ajudando a desentalar isso e digerir isso? 
Ligia: Ah, um deles é... sou eu mesma, minha força de vontade.

Anna: Uhn.

[Ligia segue descrevendo recursos que ela acredita que lhe "dão forças para superar": sentimento por ele, respeito, vontade de ficar junto, religião]

[...]

Anna: Aí, quando eu perguntei dos ingredientes que te ajudam a lidar com essa situação específica, você me enumerou vários ingredientes que eu chamaria de "recursos", que parece que estão sendo úteis nessa... nessa sua... nesse seu entendimento, elaboração do que aconteceu, né? Que é um processo também, né?

Ligia: Unhun.

Anna: Você mesma sente que é algo que ainda está acontecendo e faz parte. Mas está, parece que está em um processo de digestão aí, já que você usou a imagem da digestão, do nosso sistema digestivo. $E$ a mesma coisa eu ia te perguntar [voltando-se para Luis], dos seus ingredientes. Quais são os seus ingredientes, seus recursos, para também estar elaborando, digerindo o evento da infidelidade.

[Luis descreve que buscou apoio com profissionais - psicólogos - e na religião. A partir destas respostas, Anna investiga qual foi o tipo de suporte que ele recebeu, e como foi ajudado em cada um destes contextos]

Em geral, a terapia é buscada quando as pessoas vivem situações problemáticas ou conflituosas e sentem que não possuem os recursos necessários para a superação destas condições. Contudo, dificilmente os clientes nunca buscaram ou tentaram qualquer forma de resolução dos problemas. Via de regra, alguns caminhos já foram percorridos neste sentido - uns com mais sucesso do que outros, mas todos foram constituindo os recursos dos quais as pessoas foram lançando mão e que vão marcando suas relações com o problema.

Investigações neste sentido oferecem a construção de conhecimentos que orientam tanto terapeuta quanto clientes. Para as terapeutas, a investigação dos recursos já tentados permite identificar aqueles que foram bem sucedidos e podem se tornar aliados do processo atual, e aqueles que fracassaram e não constituiriam uma direção útil. Para os clientes, oferece a chance de conhecerem mais sobre si mesmos e nomear ações e escolhas que talvez não tenham sido descritas, por eles mesmos, como recursos que desenvolveram ao longo de sua história. Vemos, assim, que estas ações enriquecem as conversas com informações que favorecem a superação das situações de sofrimento.

A nosso ver, estas ações possuem uma sensibilidade às contribuições construcionistas para a prática clínica (Rasera e Japur, 2004). Destacamos duas dimensões pelas quais isso se presentifica nestas ações: o foco pragmático da terapeuta, que preocupa-se com os efeitos que a conversa terapêutica tem na vida 
cotidiana dos clientes - neste sentido, Anna explora recursos já desenvolvidos pelas pessoas de modo a encorajá-las a utiliza-los em diversos contextos de sua vida; e o foco nas potencialidades dos clientes, em que a terapeuta ilumina os aspectos positivos que podem favorecer a construção da mudança.

\section{h. Temática: Explorar o genograma}

O genograma é uma descrição gráfica das relações biológicas, emocionais e legais de uma família e, em geral, inclui de três a cinco gerações (McGoldrick, Gerson \& Petry, 1985/2012). Na prática terapêutica, é uma ferramenta visual prática que permite explorar padrões e contextos familiares. Na medida em que envolve a narrativa de histórias e implica no respeito pelas múltiplas versões dos membros da família, ele pode ter um efeito terapêutico em si mesmo. Segundo os autores, a proposta do genograma parte da perspectiva de que os indivíduos estão necessariamente interligados, e cada um de nós possui um self impregnado das relações e da cultura em que estamos imersos.

No atendimento com Lina e o casal Motta, o genograma foi construído e explorado na $3^{\text {a }}$ e $4^{\text {a }}$ sessão. Uma das formas pelas quais o genograma do casal foi utilizado consiste na exploração dos dados acerca de cada uma das famílias: composição, gênero, idade, nome, casamentos, separações, quem mais é considerado da família além dos parentes consanguíneos e outras perguntas desta natureza. Estas ações deram subsídios para a obtenção de informações para a representação gráfica e a compreensão de quem são os membros da família considerados significativos para o casal, uma vez que não houve a necessidade de representar todas as pessoas da família, mas apenas aquelas das quais se lembraram.

Além destas ações, foram realizadas explorações da história a partir das informações relatadas, exemplificadas a seguir.

Terapeuta Lina, Casal Motta, Sessão 4

Estávamos retomando a exploração do genograma nesta sessão, e Vivian relata as histórias de casos extraconjugais de seu pai. Lina pergunta se é algo que ela já experienciou no próprio casamento, e ela diz que sim. Perguntamos se é algo que o casal gostaria de começar a conversar (e deixar o genograma de lado), e eles dizem que 
sim. Lina diz que gostaria de fazer algumas perguntas antes de seguirmos neste novo caminho de exploração.

Lina: Deixa eu só saber um pouquinho antes de entrar no caso de vocês. Na sua família Igor, os pais, avós, isso também é algo que você viveu, o acontecimento deste tipo coisa, você soube de ter acontecido entre outros casais?

Igor: Eu soube, mas é aquele negócio que eu te falei na semana passada. Tipo assim, eu não fico mediando a vida das pessoas. Fala se quiser, se não quiser eu não fico perguntando, não fico especulando, puxando a língua, entendeu? Eu te falei, minha avó teve vários filhos, mas meu avô teve filhos...

Gabriela: A avó [nome]?

Igor: Sim. O meu avô teve filhos com a irmã da minha avó.

Lina: Unhun.

Igor: Que acabaram agora, depois do falecimento da mãe deles, tendo a minha avó como mãe. Se era normal para eles eu não sei, entendeu?

Lina: Isso foi aqui ou isso foi na [cidade]?

Igor: Foi tudo aqui. Eles nasceram lá mas foram criados todos aqui.

[Lina levanta-se e começa a representar graficamente esta relação do avô com a irmã da avó, indicando o nascimento de filhos desta relação]

Lina: E ele teve os filhos enquanto a sua avó era viva e com o conhecimento da sua avó?

Igor: Sim, a minha avó era viva. Com o conhecimento de todo mundo! [...]

Lina: Foram quantos filhos?

Igor: Eu acho que são dois.

Lina: Dois. Você não sabe se são homens ou mulheres?

Igor: Peraí... [conversa em voz baixa com Vivian, não dá para entender]. É um homem e uma mulher. Isso aí.

Lina: Unhun. [...] Isso para eles deu problema, ou era parte de uma...

Igor: Eu não sei. Quando isso aconteceu eu não estava nem... no projeto de... não sei nada.

Lina: Para alguém que você conheça, por exemplo, o seu pai ou para os irmãos do seu pai, isso era um problema ou não era?

Igor: Eu não sei Lina, porque eu nunca conversei com eles a respeito disso, entendeu? É o que eu te falei outras vezes, eu procurava não ficar entrando nessas bola dividida.

Lina: Então existia uma ideia de "bola dividida"?

É interessante notar que a exploração dos dados e das histórias familiares permitiu ao casal entrar em uma temática que desejavam explorar na terapia (e depois descobrimos que fazia parte de suas queixas principais), mas ainda não tinham falado abertamente sobre isso conosco. Quando Vivian contou-nos sobre os casos extraconjugais de seu pai, Lina usou uma abertura na conversa para perguntar se ela havia experienciado pessoalmente esta situação e, antes de adentrar no assunto como uma questão do casal, a traição foi abordada como uma questão familiar que fez parte das vivências de diferentes gerações na família de ambos. Assim, quando passamos a conversar sobre a traição vivida no casamento deles, já tínhamos uma 
ideia dos sentidos que esse fato assumiu em cada uma das famílias e quais foram as repercussões das diferentes traições conjugais na trama familiar de cada um.

A temática a seguir, que faz parte da categoria "Ações de construção de visões relacionais", explora outro uso que foi feito do genograma nesse atendimento.

\subsubsection{Categoria: Ações de construção de visões relacionais}

As ações de construção de visões relacionais tornam mais complexas as descrições sobre si e o outro, iluminando aspectos relacionais das vivências dos clientes. Neste sentido, contribuem para a ampliação dos sentidos sobre problemas, pessoas e possibilidades de mudança, iluminando novos caminhos nas dimensões do conhecer, sentir e agir.

A seguir, o quadro 6 apresenta cada temática que compõe a categoria.

\section{Categoria}

Temáticas

Terapeuta

Ações de No uso do genograma, explorar a posição do cliente construção de em relação à própria história

Lina

visões

relacionais

Descrever ou explorar diferentes selves de uma pessoa

Anna e Lina

Fazer pergunta de implicação

Anna e Lina

Fazer explorações epistêmicas (que buscam criar contextos para os membros conhecerem mais sobre Anna e Lina eles mesmos)

Explorar ou descrever o padrão comunicacional ou relacional

Anna e Lina

Construir sentidos para além da queixa

Lina

Abordar questões sociais e culturais que entrecortam o problema

Anna

Fazer perguntas de futuro

Lina 


\begin{tabular}{lll}
\hline Categoria & \multicolumn{1}{c}{ Temáticas } & Terapeuta \\
\hline & Fazer perguntas reflexivas & Anna e Lina \\
& Fazer comentários reflexivos & Anna e Lina \\
& Fazer um reenquadramento & Lina \\
\hline Quadro 6. Temáticas que compõem a categoria "Ações de construção de visões relacionais"
\end{tabular}

Nas interlocuções com as terapeutas-participantes, construímos sentidos sobre esta categoria:

Anna: Eu sinto que tem uma preocupação imensa minha em acolher, mas um acolher buscando... é duro transformar isso em palavras né? Buscando... ahn... acolher, receber, buscando olhar para isso com outros olhos, com outra possibilidade diferente do que eles já estão trazendo. Não da mesma forma, mas oferecer possibilidades de olhar de outras formas, para ampliar um pouco o olhar deles, por exemplo. Oferecer mais ferramentas, mais ingredientes, digamos assim. A ideia é talvez ampliar o olhar, a lente que eles olham, ou transformar a forma de falar sobre. [...] Agora, o fato de buscar elementos, outras narrativas, outros elementos para compor ou talvez ajudar a construir outra narrativa, vamos imaginar as histórias preferidas e histórias subordinadas. Essa já é uma atitude, algo que eu sou convidada mais pelas ideias do Michael White sim, que é a narrativa, e do Tom Andersen. Mas aí me permitem, me autorizam, eu me sinto... acho que autorizada, eu me permito a ir um pouquinho... não sei, acho que é o nome que a gente dá, né? Porque a gente tem esses três autores, essas três ideias [Harlene Anderson, Michael White e Tom Andersen]. Então, eu acho que isso está aqui comigo, né? Talvez eu escolha mais um determinado jeito, mas eu uso mais quando eu vejo que às vezes eu busco essas outras referências para me acompanhar, porque talvez complementa aí.

Gabriela: Na hora em que você vai dando estas direções, então: "vamos atender este pedido mesmo que a conversa seja um pouquinho mais difícil", você trouxe aqui o Tom Andersen e o Michael White. Faz sentido?

Anna: É, é interessante. Faz. [...] inclusive porque, não o Tom Andersen, mas eu acho o Michael White extremamente interventivo. Que inclusive é onde eu breco um pouco, eu danço um pouquinho. [risos] Eu convido e às vezes eu desconvido. 
Para Anna, dialogar com as ideias de Michael White e Tom Andersen, no encontro com os clientes, parece permitir-lhe atuar de forma a extrapolar o que os clientes delineiam como limites para a conversa - o que foi referido pela pesquisadora como uma "conversa um pouquinho mais difícil" - e seguir por caminhos que oferecem "possibilidades de olhar de outras formas", ampliando as visões trazidas pelos clientes. Nestes momentos, uma atuação mais diretiva parecelhe mais possível quando ancorada nas ideias propostas por Michael White. É interessante notar, contudo, que a terapeuta "breca" o impacto dessas ideias em sua prática cotidiana à medida que estas lhe colocam em uma posição mais diretiva como terapeuta. Tal entendimento contrapõe-se ao que Anna entende como uma postura colaborativa, um lugar de "hóspede" na relação que cria com seus clientes.

$\mathrm{Na}$ interlocução com Lina, ela afirma:

Lina: E aí, para mim, a terapia está ligada à mudança, sim. Eu vou falando e fico conversando com os textos [...] Eu já vi algumas coisas, assim, por exemplo, o que é terapia de fato, o que você vai definir como terapia? E aí, pra mim, a terapia é uma conversa que produz mudança. Se for uma conversa que não produziu mudança... por exemplo, a pessoa veio chorou, chorou, chorou, se sentiu aliviada de ter chorado, mas ela vai embora descrevendo da mesma forma, descrevendo a situação da mesma forma, eu não considero um bom trabalho terapêutico. Para mim, isso ela poderia ter feito em outros lugares. Agora, eu sei que isso não é uma ideia geral.

Para Lina, a própria definição de terapia implica na construção de um processo que produza mudança de significado para os clientes. Assim, as ações de construção de visões relacionais possuem dimensão crucial em sua prática, na medida em que estão orientadas para atender este propósito.

A seguir, apresentamos trechos que ilustram cada temática da categoria, com sua definição e discussão.

\section{a. Temática: No uso do genograma, explorar a posição do cliente em relação à própria história.}


Essa forma exploração das informações do genograma traz um enfoque particular e, ao nosso ver, convidativo para a construção de informações com maior potencial transformador para os participantes da sessão. Diante das histórias familiares que vão sendo contadas ao construir o genograma, há uma exploração de como o cliente se posiciona, se posicionou no passado ou é posicionado pelas pessoas de sua família em relação a diferentes assuntos e vivências.

Terapeuta Lina, Casal Motta, Sessão 3

Após explorarmos os dados para composição do genograma de Igor, Lina inicia uma exploração mais voltada para as relações e as ideias de Igor acerca de sua própria família e como ele se posiciona e é posicionado na mesma.

Igor: Como todo mundo da família diz que o [nome do pai] é louco, é o "louco".

Lina: Qual é o [nome]?

Igor: O meu pai.

[Lina levanta-se e escreve "louco" ao lado do nome do pai de Igor]

Igor: Então quando o meu pai tinha que falar alguma coisa, ele chegava e falava, não mandava recado, entendeu? Ele chegava e expunha o que tinha que expor. Tanto é que ele ficou muito tempo sem ir na casa da minha avó por discussões lá [...]. E depois que eu saí da casa dos meus pais, eu não... sabe... não teve mais aquele negócio de você... como tem, eu ouço meus amigos dizerem que vai na casa mãe, almoça na casa da mãe, vai dormir... eu já não... eu vou lá, começam a falar e eu não acho legal. Certas coisas eu falo: "ó, não precisa nem me contar isso aí porque eu não... não vou conseguir ficar ouvindo sem externar o que eu penso". E se eu falar o que eu penso, eu vou acabar ofendendo alguém. Então para não ofender eu prefiro não ouvir.

Lina: Você tinha acabado de falar que o [nome do pai] era chamado de "louco" porque ele falava o que tinha que falar...

Igor: É, ele falava, era igual o meu avô. Falavam que ele era a cópia do meu avô.

Lina: ... e aí você está falando que você nem ia em [cidade dos pais] porque senão você ia ter que falar as coisas. Aí você ia ficar parecendo com o [nome do pai], o "louco"?

Igor: Não, não, não é isso. [pausa] Voltando lá, para não perder então. Eles falam que o meu pai era louco porque tudo ele brigava. É o que eles falam que eu faço, tudo eu brigo, tudo eu discuto...

Lina: "Eles" quem falam isso?

Igor: As minhas tias todas, do meu pai.

Lina: Daqui, tá.

Igor: Todas elas e todos eles [tios]. Tanto é que numa bola dividida eu preferia nem entrar, porque a chance de ganhar é mínima, entendeu?

Lina: Quando que você se lembra de começar a receber esse rótulo do "briguento", do "briga por tudo"?

Igor: Comigo?

Lina: É.

Igor: [pausa]. Vixe, esse negócio de tempo é complicado.

Lina: Foi antes dos 10, dos 10 aos 20...

Igor: Não, foi depois dos 20. Antes dos dez eu não era brigão. Ou será que eu era? [...]

Lina: Deixa eu ouvir um pouquinho do Igor com o [nome do pai]. Quando você era criança pequena e você vê seu pai ou seu avô tendo estes 
rompantes que as pessoas estranhavam, você lembra o que você pensava disso? Você via isso como coragem, como valentia?

Igor: Eu não via, porque eu não presenciava.

Lina: Tá. Mas você ouvia as pessoas falando do teu pai, que ele era briguento.

Igor: Sim, como a gente ouvia... nós somos briguentos, né? Meu pai era briguento, meu tio, vai indo...

Lina: $\mathbf{E}$ você, como criança, qual era o rótulo desses nomes? Esse aqui é "enrolado", esse aqui é "briguento"... qual desses rótulos parecia o mais bacana? Qual parecia, aos seus olhos de criança, se você tivesse que escolher um para ser, quem você teria escolhido?

Igor: [pausa] $\mathrm{Na}$ atual conjuntura, hoje, nenhum.

Lina: Com a cabeça do Igor de 44 anos. Com a cabeça do Igor de 8...?

Igor: Não, porque eu não tinha contato direto com eles [...]

Lina: Das formas que você foi vendo, dentro da tua família aqui [apontando a família do pai] de negociar diferenças, de resolver problemas, quem que tinha um jeito que hoje você olha e fala: "nossa, esse é um jeito legal".

Igor: Nenhum.

Lina: Nenhum? [Pergunta sobre alguns tios, falando nomes]

Igor: Nenhum.

Lina: E aqui na família da [nome da mãe], tinha alguém que tinha um jeito legal?

Igor: A gente não tinha contato com a família da minha mãe.

A pergunta de Lina oferece a Igor a oportunidade de perceber um padrão intergeracional no estilo de comunicação e na forma de se relacionar dentro da família. A terapeuta convida-o a pensar sobre sua própria posição nas relações que mantem com a família nuclear, e também surgem relatos sobre as posições que tias e tios lhe oferecem na família extensa - “aquele que briga e discute por tudo”. Mesmo as situações que ele não presenciava, como os rompantes de raiva do avô, tio e pai, passaram a constituir as histórias que contavam sobre eles e que Igor passou a contar sobre si mesmo - "eles eram briguentos" tornou-se "nós somos briguentos". Igor constitui sua própria história e seu modo de ser nas suas relações a partir das histórias de seu avô, tio e pai.

Lina segue a exploração investigando se alguém de sua família teria constituído um modelo positivo em termos de formas de comunicação e resolução de problemas. Contudo, ele enfaticamente afirma que não teve esses modelos positivos em sua família de origem, tanto materna quanto paterna.

Na interlocução, Lina comenta sobre o uso que faz do genograma:

Lina: E assim, enquanto eu estou com o cliente, eu me sinto muito à vontade pra ir, para... passear. Até coisas, por exemplo, 
nem sei porque eu pensei nisso, mas coisas, por exemplo, até da sistêmicas, sabe? [...] Não como coisa explicativa, nada disso, mas vem como: "será que conversando por aí vai ser útil? Será que a gente consegue construir sentido fazendo isso?”. E aí o esforço acaba sendo de que jeito que você traz isso pra conversa, né? Você não vai fazer, às vezes, com o nome que a teoria dá. [...] Tem aquelas coisas clássicas mesmo que eu faço, por exemplo, genograma. [...] Muitas vezes eu uso genograma. De novo, se você falar: "você está usando da forma como a McGoldrick usa?”. Eu acho que não, nem lembro que jeito ela propõe. Mas para mim é como recurso de conversa também [...] como possibilidades das conversas. Eu acho que quando a gente usou com a Vivian e o Igor, a gente já tinha uma ideia da violência como algo presente em contextos, né?

Gabriela: Tinha. Porque vieram algumas informações de um pai violento e tal, e aí a gente foi...

Lina: É... eu acho que a gente quando usou, já usou com intenção de olhar pra isso.

Gabriela: É... e na verdade o que mais apareceu, que foi interessante, o imprevisível do encontro, né? Foi a questão da traição... porque acabou sendo esse o link, né, que parece que pra eles ficou forte. De olhar pras traições. Também é um tema, aí, das gerações.

Lina: E que a traição era mais a da família dela, a que incomodava muito era mais da família dela.

Lina faz um uso situado do genograma como uma inspiração para suas ações. Quando afirma que o utilizamos com o intuito de explorar a questão da violência como algo presente no contexto familiar, vemos que a terapeuta conhece o embasamento sistêmico da ferramenta e seu foco na busca pela repetição de padrões intergeracionais. Assim, a princípio a utilização tinha um objetivo estabelecido $a$ priori entre nós, que era abordar a questão da violência entre o casal. Contudo, o andamento da conversa leva-nos a falar sobre casos extraconjugais ocorridos em diversos casamentos de ambas as famílias, e este torna-se o tema que o casal deseja explorar, o qual era o gatilho para muitas brigas e discussões que culminavam em violência entre eles. Este desenrolar da sessão e a forma como Lina descreve a prática inspirada pelo genograma indica, a nosso ver, um uso relacional da ferramenta. Primeiramente, porque o objetivo previamente estabelecido é prontamente abandonado quando a conversa indica outras possibilidades de conversa. Em segundo lugar, Lina destaca sua preocupação em trazer os recursos sistêmicos como disparadores para conversas que podem ser transformadoras e úteis para a construção de sentidos com os clientes. Além disso, Lina enfatiza sua preocupação em como poderá trazer estes recursos para a conversa sem entende-los como 
explicações ou, em outras palavras, como verdades sobre as vivências dos clientes. Diferentemente, ela ocupa-se em "traduzir" estes pressupostos mais livremente, sem estar excessivamente focada nos nomes que as teorias oferecem, mas sim em como os pressupostos podem constituir-se em recursos úteis para o estabelecimento de conversas generativas.

A exploração e transformação das relações atuais é descrito por McGoldrick, Gerson e Petri (2012) como parte da atuação do terapeuta no uso desse recurso. Assim, embora Lina afirme não saber como os autores propõem o uso do genograma, o tipo de exploração que a terapeuta faz possui muitas semelhanças com as propostas dos autores para as entrevistas com genograma. Nas palavras dos autores: "As famílias geralmente precisam de ajuda para expandirem a sua visão de si mesmas e de sua história dentro do contexto - para visualizarem a continuidade da sua experiência com seus antepassados, com a família atual e com a comunidade e perceberem sua conexão com aqueles que virão depois deles" (p. 221).

\section{b. Temática: Descrever ou explorar diferentes selves de uma pessoa}

Anna e Lina descrevem ou exploram diferentes selves de uma pessoa, desafiando a ideia de um self único, cuja coerência e sanidade ancora-se em apresentar-se da mesma forma em diferentes relações.

Terapeuta Anna, Casal Luis e Ligia, Sessão 8,

Ligia e Anna começavam a conversar, e Ligia trazia suas dificuldades em relação à ter iniciativa e convidar Luis para iniciarem momentos de maior intimidade sexual, afirmando que, ao mesmo tempo em que fica "travada", também pensa que é algo que "não tem problema nenhum".

Anna: Interessante, né Ligia? Porque olha, parece que você tem duas Ligias aí conversando com você, no mínimo, pelo menos.

Ligia: É, eu diria que tem mais um monte [risos]

Anna: É, né? Eu imagino que tem aí, né? A gente podia olhar por aí. Porque eu te pergunto: "você acha que é da Ligia essa ideia?". E você fala: "eu acho que é da Ligia, é meu isso". Mas você traz a ideia de que culturalmente, historicamente, foi-se aprendendo...

Ligia: Então, quando eu comecei a ler o livro, eu pensei sobre isso. Eu pensei, falei: "nossa, olha, eu acho que a minha ideia de que se eu procurar, eu falar alguma coisa, nossa, o que será que ele vai pensar?". Aí, me dá assim, eu: "não, ele não vai pensar nada. O que ele poderia pensar?” 
Anna: E aí é a voz de quem que tá falando aí, agora: “não, ele não vai pensar nada, ué"

Ligia: Não, eu mesma que falo, né?

Anna: Eu sei que é você mesma, mas você acha que se a gente pudesse olhar para um nome dessa Ligia que fala para você: "olha, não vai tomar a iniciativa, porque ele vai pensar que é muito 'saidinha"'. Aí vem a outra Ligia e fala assim: “não! Imagine! E daí? O que tem, vocês são casados!”

Ligia [rindo]: Tem duas mesmo!

Anna: Que nome a gente poderia dar? Porque você falou que tem outras também, né?

Ligia: Eu acho que é a Ligia-recatada.

Anna: Uma Ligia-recatada que vem e fala: "não pode, Ligia! Onde já se viu? Você é uma menina de família, não se faz isso!". É mais ou menos por aí? Ligia: É.

Anna: E qual é o outro nome, da outra Ligia que fala: “o que é isso? Vocês são casados! Vocês namoraram. Qual é o problema disso?”

Ligia: Eu acho que é aquela Ligia-independente, que toma as iniciativas da vida... sem ser sexual e amorosa, aquela Ligia que toma a iniciativa, toma as rédeas do negócio e vai. Porque eu tenho esse jeito que a gente já conversou...

Anna: Pró-ativo...

Ligia: É, que vai, que faz, que não depende de nada, vai e faz. Acho que é essa Ligia que fala: "não!"

Como o trecho evidencia, é uma exploração que vai se desenrolando e tomando forma à medida que uma interlocutora suplementa as falas da outra. Não há, neste sentido, um caminho pré-determinado ou perguntas preparadas de antemão. É o ir e vir da conversa que dá a direção às terapeutas, que escolhem aberturas e alinhavam a conversa de modo a dar visibilidade aos diferentes eus, suas ações e seus efeitos na vida dos membros da família ou casal.

Na interlocução com Anna, produzimos sentidos sobre o uso deste recurso:

Gabriela: As ideias da Telma Lenzi te inspiraram a fazer aquela conversa com a Ligia?

Anna: Muito. Muito. Eu tinha lido e estava muito interessada [...] Esse barulho interno, essa briga toda com várias... Me faz sentido essa ideia dos personagens, ajuda muito. Você pode ter um personagem aí que te incomoda. Eu digo "Você pode ter", é claro que a gente está falando em vozes, em histórias conversacionais, óbvio. Mas assim, é um jeito que me atendeu bastante viu?

Gabriela: E aí você usou esse recurso na prática.

Anna: Tenho usado. [...] eu não uso muito o termo "personagem", eu falo assim: "Que Gabriela é essa que está falando? Que Gabriela é essa?"

Gabriela: Você dá um nome.

Anna: Eu vou: "que nome você daria?", vou usando mais assim. [...] Naquela vez que eu fiz com a Ligia, eu estava claramente 
indo com essa ideia, com essa ferramenta para poder... até naquele momento achei que poderia ser útil para ela ver que não tinha só a Ligia-recatada que teve uma educação $x$. Ela tem também a Ligia que estuda, que busca.

Neste momento da interlocução, fazemos referência às ideias da autora brasileira Telma Lenzi (Lenzi, 2013), que utiliza a noção dialógica e relacional do self para propor uma prática clínica baseada na exploração dos nossos personagens internos, que seriam estas diferentes vozes que povoam nossas conversas internas. Para a autora, é importante reconhecer, nomear e legitimar estes personagens internos, favorecendo a flexibilidade, multiplicidade e autoria relacional na dissolução dos problemas. K. Gergen (2008), à proposito do self dialógico, afirma que o uso terapêutico desta noção deve estar embasado nas múltiplas facetas do self e nos potenciais de ação que cada uma delas apresenta.

Anna afirma que, nessa conversa com Ligia, estava inspirada pela proposta de explorar, nomear e caracterizar as personagens internas que influenciavam suas ideias e ações na relação com Luis. À medida que conversam, Ligia vai trazendo para o momento presente algumas vivências de seu passado que podem ser úteis para pensar sobre estas questões a partir de novos prismas. Anna, assim, vai trabalhando a partir do entendimento das personagens como histórias conversacionais: considerando o modo como Ligia foi educada e o ambiente em que cresceu (em uma fazenda, no início da década de 60, com pai e mãe rígidos e de pouca conversa), Anna legitimava as dificuldades de Ligia para lidar com a sexualidade de formas mais livres e espontâneas. Assim, foi convidando para a conversa uma outra Ligia, que rompia estes limites e fazia aquilo que queria, agindo com mais ousadia. Esta Ligia ousada, autônoma e independente fazia parte das histórias conversacionais de Ligia, apresentando-se em diferentes contextos (profissionais e familiares, por exemplo) e também fez parte das conversas na terapia, quando Ligia nos contou sobre suas conquistas profissionais e o modo como estava conseguindo prover o sustento do casal nos últimos cinco anos, pois Luis estava desempregado. Arrefecendo a força das narrativas cristalizadas acerca do problema, Anna expande as facetas pelas quais Ligia pode se apresentar diante dos desafios vividos no casamento - recursos estes que ela já usara (e muito bem) para lidar com desafios em outros contextos de sua vida. 
Nos atendimentos com ambas as terapeutas-participantes o uso deste recurso ocorreu em momentos nos quais descrições cristalizadas que as pessoas faziam sobre si mesmas ou os outros cerceavam as possibilidades de mudança. As explorações de diferentes selves surgiram com diferentes enfoques: explorar o conflito, definir competências, construir um enfoque apreciativo, flexibilizar narrativas cristalizadas que possuem um foco pejorativo ou incapacitante.

\section{c. Temática: Fazer pergunta de implicação}

As perguntas de implicação explicitam a coparticipação das pessoas na manutenção do problema e também na busca por soluções.

Terapeuta Anna, Casal Luis e Ligia, Sessão 10

Luis relata-nos problemas de relacionamento que tem com as famílias extensas de ambos - tanto dele quanto de Ligia. Em seguida, afirma enfaticamente que a única pessoa com quem realmente deseja ficar bem é Ligia.

Anna: E aí, qual é a sua contribuição, a sua colaboração para que isso aconteça?

[breve pausa]

Luis: Foi buscar a ajuda de vocês.

Anna: E...? A nossa ajuda e...? E a sua [ênfase] colaboração?

Luis: Conversar mais com a Ligia.

Anna: $\mathbf{E}$ o que você acha que precisa acontecer da sua parte, qual é a sua parcela para que isso aconteça, Luis?

[breve pausa]

Luis: Ah, dentro de casa, haver mais diálogo, né?

Anna: $E$ o que você está disposto a ofertar para que isso aconteça? Da sua parte, o que é que você vai fazer, que você pretende fazer?

Luis [rindo]: Conversar mais com ela.

Anna: E como é "conversar mais com a Ligia"? Como você fala em termos práticos? Por exemplo, domingo ela veio, fez uma pergunta, fez um comentário, e você ficou quieto. Como seria conversar? Vamos lá no "como se", que é a ideia que a Gabriela trouxe. Vamos imaginar que ali era o momento: ela chegou, ela iniciou uma conversa, fez uma pergunta, fez uma reflexão, te ofertou uma reflexão, você disse para nós que ficou pensando, só que ficou calado. Então a conversa parece que se encerrou ali.

Luis: É, eu não vou... eu vou me observar mais em não ficar calado. Em dialogar, perguntar, e...

Anna: Então você está disposto a fazer isso?

Luis: Ah, estou sim.

Anna: E a Ligia? [...] Qual é a sua parcela na mudança que vocês querem na relação de vocês? 
Terapeuta Lina, Casal Motta, Sessão 6

Esta sessão se inicia com uma proposta, de nossa parte, de que a conversa de hoje focalizasse a construção do futuro que eles desejam. Lina explora com cada um deles o que precisa acontecer na terapia para que sintam que a conversa está ajudando.

Vivian: [...] Eu acho que é o tempo, porque a conversa mesmo... eu acho que conversar não vai ajudar muito. É o tempo, sabe quando fala "dar tempo ao tempo"?

Lina: Unhun.

Vivian: É o tempo. E o comportamento.

Lina: Você falou "dar tempo ao tempo". O que, além de tempo, você tem que dar para esse tempo, para o tempo ser útil para você? Porque tempo vocês já tiveram, né?

Vivian: Eu acredito que não.

Lina: Não?

Vivian: Ainda não. Porque não dá o tempo de se firmar, porque nunca dá o tempo de se firmar. Na hora que a gente está começando a caminhar...

Lina: Ah, o tempo que você está se referindo é ficarem juntos.

Gabriela: É.

Vivian: É, é o tempo físico mesmo.

Gabriela: Um tempo maior.

Lina: Ah, tá. [...]

Vivian: Então realmente é o tempo físico e o comportamento, não tem outra coisa que eu acho que vai ajudar a voltar a credibilidade. [...]

Lina: Vivi, a gente entende, veja se você concorda. Que para ficar juntos precisa de dois.

Vivian: Sim.

Lina: Dois estarem ali empenhados em ficar juntos. Tem um lado que para ficar junto implica do Igor não sair, né?

Vivian: Sim.

Lina: Então tem um pedaço que é dele. $E$ do seu? $O$ que de você depende para que ele continue?

Vivian: Do comportamento, das atitudes.

Lina: O que, do seu [ênfase] comportamento e da sua [ênfase] atitude, ajudaria ele a não ter este rompante de sair?

Vivian: Do meu comportamento. [breve pausa, suspiro profundo de Vivian]. Uhn. Do meu modo de ver, é atenção o tempo inteiro, que eu não tenho condição de dar.

Lina: Uhn. Das coisas que você tem condição de dar, Vivi, porque aqui a gente lida com os limites.

Vivian: Tá.

Lina: Ninguém consegue dar o que não tem. Então dentro dos limites, dentro das condições, dentro do que te é viável, o que você acha que pode oferecer que ajude o Igor a ficar?

Vivian: Não sei [risos].

Lina: A gente pode tomar isso como uma pergunta para o Igor?

Vivian: Pode.

Estas perguntas e comentários, que implicam os clientes nas mudanças que desejam, trazem a dimensão da corresponsabilidade na manutenção das situações sentidas como sofredoras. As terapeutas convidam os clientes a perceberem a corresponsabilidade na criação e continuidade das dificuldades relatadas e, sobretudo, na parcela que cabe a cada um mudar. 
São ações que levam os clientes para além de uma postura que afirma que "o culpado é o outro, e se ele mudar, tudo ficará bem"; ou então "vir na terapia já é suficiente para que as mudanças aconteçam”. Anna enfatiza os esforços que precisam ocorrer para além do momento da sessão, indicando que não há uma correlação necessária entre estar na terapia e mudar. Lina, semelhantemente, cria uma exploração das formas como Vivian pode se responsabilizar para evitar as constantes separações do casal (em que Igor sai de casa e vai morar, temporariamente, em outro lugar). E, percebendo a dificuldade de Vivian em indicar como ela pode agir neste sentido, transforma a pergunta em uma indagação para Igor, também implicando-o no processo de mudança da esposa e, consequentemente, na transformação da situação do casal.

$\mathrm{Na}$ interlocução com Lina, em um momento em que a terapeuta justifica diversas ações com base em um pressuposto teórico, produzimos sentido sobre esta temática:

Lina: [...] É essa coisa, acho que a gente pode ir dando o nome de ajudando a pessoa a sair da queixa e encontrando caminhos onde ela fique mais próxima daquilo que ela gostaria de estar. Que também eu acho que nomes possíveis pra isso é empoderamento. Mas eu gosto da ideia de ajudar a pessoa a ficar mais próxima daquilo que ela identifica como podendo ser o melhor dela. Ou a relação dela podendo ser uma melhor relação do que ela está tendo. E nos casais, também a mesma coisa, quer dizer, os casais ficam: "ah, mas tá ruim, ah mas tá ruim, mas ele fez não sei o quê, mas ela fez não sei o quê”. Que fica aquela coisa da queixa, da queixa, da queixa... E eu entendo que identificada a queixa, identificado o que não está legal, de que jeito eu gostaria que fosse? Eu entendo que a nossa função é ajudar a pessoa a se ver nesse movimento e ir nomeando esse movimento pra poder colocar isso em ação. E aí, para mim, nisso está a questão do andaime.

Gabriela: Unhun.

Lina: De ir construindo esses andaimes.

Gabriela: Uma das ações que eu destaquei aqui, que é "Construir sentidos para além da queixa", que a pessoa traz a queixa e você fala: "então, que pedido que tem?" Seria então um pedacinho desse caminho que você está buscando construir na criação desses andaimes, dessas mudanças.

Lina: Um pedacinho, sim. "Fazer pergunta de implicação" eu acho que também [pausa, lendo o material] ahn... eu acho que "explorar os sentimentos e intenções que movem determinadas ações", porque eu acho que quando você identifica a intenção ligada à ação, o fato de você identificar eu acho que já é o primeiro passo pra você fazer mudanças. "Fazer perguntas de 
futuro", "Explorar a exceção do problema" [pausa] Olha, de forma indireta, eu acho que o "Reenquadramento", "Dar tarefas", mas eu acho que é de forma indireta.

White (2012) descreve as conversas de construção de andaimes como baseadas no conceito de zona de desenvolvimento proximal, proposto por Lev Vigotski. A zona de desenvolvimento proximal é a distância entre o que uma pessoa pode conhecer e alcançar de maneira independente, e o que pode alcançar com a colaboração de outros (White, 2012). A aprendizagem, entendida como resultado da colaboração social, é realizada por meio de saltos manejáveis - ampliações gradativas que exercitam novas tarefas e a criatividade, em cada novo degrau que a pessoa vem a ocupar. Desse modo, White (2012) entende que a zona de desenvolvimento proximal pode ser percorrida por meio de conversações de construção de andaimes, nas quais o não-familiar é percorrido em degraus manejáveis.

$\mathrm{Na}$ construção de justificativas para suas ações, Lina descreve aquilo que acredita como sendo uma responsabilidade do terapeuta: acompanhar os clientes na identificação daquilo que eles desejam mudar (queixa), iluminar aqueles momentos em que as pessoas parecem ficar presas na queixa e no relato dos problemas, explorar cenários desejados e novas formas de ser e estar em relação, e acompanha-los na colocação disso em ação. Estas diferentes ações parecem delinear uma caminhada conjunta, em que terapeutas e clientes andam lado a lado, construindo paulatinamente os conhecimentos e recursos que dão suporte para novos patamares de ações e significações. Ao nomear este processo conjunto com os clientes, Lina lança mão do conceito de andaimes como o referencial que lhe dá subsídios para galgar estes degraus com os clientes. E, como a segunda parte do trecho indica, a construção destes andaimes demanda diversas ações por parte da terapeuta, sendo que algumas das quais foram nomeadas em nosso processo de análise: perguntas de implicação, construir sentidos para além da queixa, explorar sentimentos e intenções que movem determinadas ações, perguntas de futuro, explorar a exceção do problema, reenquadramento e tarefas. Ao longo do texto que se segue, exploraremos cada temática com suas definições e exemplos. 


\section{d. Temática: Fazer explorações epistêmicas}

As explorações epistêmicas criam contextos para que os membros conheçam mais sobre eles mesmos. São ações que permitem a construção de conhecimentos em diferentes sentidos: cada um conhecer mais a si mesmo, conhecer mais o outro, conhecer melhor o funcionamento e as dinâmicas do casal, família ou subgrupos dentro da família (por exemplo, especificidades da relação entre pai e filha).

Terapeuta Lina, Família Silva, Sessão 3

Renata havia falado de suas preocupações quando Amanda sai de casa e chega tarde, dizendo que gosta de saber onde e com quem a filha está. Lina segue explorando esta questão com a família.

Lina: Quando você escuta ela dizer que fica com a ideia de que pode precisar de te localizar, você tem ideia do que ela está falando ou qual é essa preocupação?

Amanda: Eu acho que é desnecessário [risos]

Lina: Aí conta um pouquinho, não é nem tanto para mim, tá? Mas para ela mesmo, né? Porque é isso que eu estou dando o nome de "um conhecer a cidade do outro". Para ela, isso é importante. Para você, isso é desnecessário. Conta um pouquinho para a gente esse caminho que você faz para concluir que isso é desnecessário, que isso não é importante, que ela não precisa disso para dormir bem. Então conta, assim, o que você vai imaginando quando chega nessa ideia. A gente não está aqui para julgar se a ideia é boa ou não. Mas você conhece bem isso, se sente muito segura nisso, e ela não conhece. Então ajuda ela a ir para essa sua segurança.

Amanda: Não, porque eu sou consciente, eu sou consciente do que eu estou fazendo. E também tenho caráter no que eu faço, então eu acho que é desnecessário a preocupação. Eu acho que tem que ter preocupação, mas não nesse nível.

Lina: Unhun. O que poderia tranquiliza-la... ahn... porque você fala: "eu tenho caráter, eu tenho consciência", né? Mas eu fico com uma sensação que isso ainda não daria para ela essa ideia de "onde eu vou procurar minha filha se eu precisar procurar". Então, de que jeito esse caráter e essa consciência podem, juntos, ajudar sua mãe a ficar tranquila de que ela vai conseguir te encontrar se ela precisar?

Amanda: Se me procurar tem que ter um motivo. Porque se eu estipulo um horário, eu vou chegar naquele horário. Não precisa dela me procurar.

Lina: Unhun. Você já perguntou para ela o que a faz imaginar que vai ter que te procurar?

Amanda: Não [risos]. É uma coisa louca, assim.

Lina [voltando-se para Renata]: Você quer contar para a Amanda o que é que te leva para essa ideia que em algum momento você vai precisar procurar ela?

Renata: Ai, às vezes pode acontecer algo. 
Lina: O que?

Renata: Que nem já aconteceu.

Lina: O que?

Renata narra ocasiões em que Amanda foi assaltada enquanto andava sozinha, à noite.

Raul: Eu acho que as coisas de avisar tem que avisar mesmo [...] Isso eu concordo com a Renata. Não é à toa que eu chego e faço a Renata perguntar.

Lina: Você faz a Renata perguntar?

Raul: É. Porque como...

Lina: Então a Renata é porta-voz [rindo]

[Renata ri]

Raul: Eu já chego e já cobro da Renata, porque como eu e ela [Amanda] não tinha muito esse diálogo, então eu já pego... então, chama uma responsabilidade pelo menos né?

Lina: Para avisar onde está, você dá o nome para isso de responsabilidade [ênfase].

Raul: Sim. Porque é o mínimo [...]

Lina: Você também fica tranquilo quando você sabe onde está e com quem?

Raul: Sim. Eu só não vou ficar quando não chegar no horário. Aí eu falo: "por que não chegou?”. Aí eu já vou pensar que está acontecendo alguma coisa.

Vemos que é um enfoque bastante específico que, nesse trecho, é anunciado pela terapeuta: seu foco primordial não é gerar informações úteis para ela como terapeuta, mas sim permitir aos membros da família conhecerem mais uns aos outros. Utilizando a metáfora de cada um ser um visitante na cidade do outro, Lina os convida a tornarem-se mais curiosos e abertos para compreender as visões e entendimentos de cada um.

Anna também utiliza este recurso em diversos momentos do atendimento de casal. Algumas vezes, ela fazia a mesma pergunta para os dois membros do casal (por exemplo, pergunta a cada um deles como determinada vivência foi encarada). Ou, quando havia o comentário de um cônjuge sobre o outro ou sobre algum aspecto da relação, a terapeuta dá voz para que o outro cônjuge diga o que pensa ou sente acerca da afirmação. Sobre o uso deste recurso, Anna comenta:

Gabriela: Então, circular perguntas entre o casal, me chamar para as conversas, em determinados momentos você fazia isso, perguntar a opinião de outras pessoas [...] e aí eu acho que a gente já entra um pouco na especificidade da terapia de família e de casal, né? Que às vezes... 
Anna: Dentro do nosso... principalmente, eu acho, dentro dessa perspectiva nossa [...] Da polifonia, né? Do processo reflexivo. $\mathrm{Eu}$ penso que entra no processo reflexivo porque ao mesmo tempo que eu estava tentando conhecer por onde andavam os entendimentos de cada um e cada um estar se ouvindo, também de outras vozes que pudessem estar ali, ocupando ou permeando os entendimentos. E aí a ampliação, um pouco. Então quando eu pedia pra você entrar, também na possibilidade de gerar uma ampliação, na potencialidade de ampliar aí uma reflexão. Então eu vejo como muito...

Gabriela: Essa inspiração, né? Que eu acho que isso traz uma dinâmica interessante. Por exemplo, o Luis falava uma coisa e ao invés de responder você fala: "o que a Ligia pensa sobre isso? Vamos ver com ela?”. Então eu acho que isso se concretiza de uma forma interessante na sessão.

Anna: E, novamente, desmistificando ou sei lá se existe esse mito, mas me posicionando não como alguém que vai saber $a$ priori o que é melhor pra eles. [...]

Gabriela: Uhun.

Anna: Acreditando nesse diálogo como potencialmente importante para gerar novos sentidos, ou não.

Anna justifica suas ações por meio das ideias de polifonia e processos reflexivos. Como afirmamos no capítulo introdutório, as práticas terapêuticas com uma sensibilidade pós-moderna enfatizam a multiplicidade de maneiras pelas quais um problema, pessoa ou situação podem ser descritos (Rasera \& Japur, 2004). Nesta perspectiva, o terapeuta busca dar voz a esta polifonia, colocando em conversa a diferença, a pluralidade e a diversidade que emergem quando cada membro dispõe de um lugar seguro e legítimo em que pode expor o que pensa com uma finalidade terapêutica. Andersen (2002) afirma que a ideia básica dos processos reflexivos é a troca: a partilha de significados que sejam inusitados o suficiente para gerar uma mudança para as pessoas - ou, nas palavras do autor, que sejam adequadamente incomuns e possam gerar ampliações e novas construções por parte dos envolvidos. O uso destes conceitos na prática clínica favorece a criação de contextos em que Anna explora e enfatiza a multiplicidade de perspectivas envolvidas no assunto em questão. Dito de outro modo, o uso da proposta dos processos reflexivos constituiu-se em uma maneira de colocar em prática a polifonia. Além disso, promove a utilização da coterapia como um recurso para que novas ideias e pontos de vista façam parte da conversa terapêutica.

O excerto do atendimento de Lina ilustra uma grande sensibilidade, por parte da terapeuta, para o potencial transformador de uma orientação epistêmica na 
terapia, e que parece se aproximar do uso de perguntas circulares para a prática terapêutica (Tomm, 1988). Lina anuncia, logo no início do trecho, seu interesse em promover um espaço em que cada membro da família possa conhecer um pouco mais do outro e de seu mundo - "sua cidade”, como indica a metáfora. Fazendo perguntas que permitem que cada pessoa traga suas ideias, preocupações e pontos de vista, a conversa culmina em um apontamento de Lina que ilumina um padrão que conecta os membros em torno destas preocupações: a mãe porta-voz, posicionada entre o pai e a filha, que não conversam diretamente entre si7. Além de proporcionar que cada um traga seus entendimentos, uma sensibilidade à polifonia, Lina ilumina um modo de relacionamento que conecta todos os membros da família de forma a produzir e reproduzir, cotidianamente, elementos conflituosos da relação entre eles. Segundo Tomm (1988), as perguntas circulares partem de suposições sistêmicas, entendendo que há uma interligação entre todos os acontecimentos e membros da família, e dão forma a uma exploração em que o terapeuta não se alia a ninguém, não escolhe uma visão "correta”. Lina indica este ponto quando afirma que "a gente não está aqui para julgar se a ideia é boa ou não", fortalecendo o caráter de uma conversa para eles se conhecerem. Para o autor, as perguntas circulares possuem efeitos libertadores na medida em que as pessoas podem liberar-se de pontos de vista prévios: neste processo em que os membros escutam uns aos outros e escutam a si mesmos, a família pode ir fazendo suas próprias conexões sobre as situações vividas e encarar as dificuldades sob uma nova perspectiva.

As ações de Lina, na medida em que estão focadas na construção de conhecimentos por parte da família, também aproximam-se da ênfase no processo relacional que ocorre no encontro terapêutico, em detrimento da ênfase nos conteúdos das conversas (Anderson \& Gehart, 2006). Em outras palavras, aquilo que se fala é relevante na medida em que permite a construção de processos colaborativos de conhecimento mútuo.

É a este processo de construção de conhecimentos sobre si e sobre o outro, em uma exploração com foco transformador e generativo, que estamos denominando explorações epistêmicas. Por sua formulação e pelo caminho de investigação que é seguido, as ações exploratórias epistêmicas buscam o surgimento de novos

\footnotetext{
7 É importante ressaltar que a ênfase no padrão não era a intenção de Lina quando fez a exploração e, por isso, sua ação foi categorizada como uma exploração epistêmica. Ações mais abertamente voltadas para a nomeação e exploração de padrões foram categorizadas na temática a seguir: "explorar ou descrever o padrão comunicacional ou relacional".
} 
conhecimentos - novas percepções, nomes e classificações para comportamentos e escolhas, outras formas de entender e dar sentido para a própria experiência, um novo ponto de vista acerca das ações do outro, uma maneira inusitada de entender um acontecimento que sempre se repete na família ou casal.

\section{e. Temática: Explorar ou descrever o padrão comunicacional ou relacional}

As ações de explorar ou descrever o padrão comunicacional ou relacional oferecem à família uma narrativa que ilumina aspectos da coordenação entre as pessoas, geralmente correlacionando as dimensões do agir e do sentir.

Terapeuta Lina, Família Silva, Sessão 4

Conversando com Raul, Lina retoma o momento em que ele falou sobre conversar com Amanda através de Renata, quando a terapeuta a nomeou como sendo uma "porta voz" nesta comunicação. Assim, fazemos uma breve conversa entre as duas terapeutas.

Lina: [voltando-se para Gabriela] Eu estou me perguntando, aqui, Gabi, em que medida que isso que o Raul vai falando para a Renata vai colocando-a em contato com essa preocupação, e fico me perguntando se isso não vai afastando daquela mãe que penteia o cabelo, uma mãe que simplesmente está ali para curtir, não para ter que ser uma mensageira, ter que ser uma...

Gabriela: Unhun.

Lina: ... é... eu fiquei com vontade de voltar nisso.

Gabriela: Sim. E quando ele foi falando, eu fui pensando assim. Isso que ele faz com a Renata, que efeito isso tem ali na relação da Amanda com a Renata. Entendeu? Algo que acontece entre o Raul e a Renata, que efeitos isso tem ali, entre a Amanda e a Renata. Como isso aparece entre as duas? Lina: Anhan. E ao mesmo tempo eu fico pensando que efeito isso vai tendo entre eles, Raul e Amanda, né?

Gabriela: Unhun.

Lina: [voltando-se novamente para a família]: Não vai dar tempo de ouvir todo mundo, mas eu fiquei com vontade de ouvir a Amanda. Amanda, o que é esse movimento dentro da sua casa, que o seu pai fala que ele não fala direto com você, ele fala com a sua mãe... como você vê isso? Você vê essas coisas acontecendo? É novidade o que você está ouvindo aqui deles?

Amanda: Não, sempre foi assim.

Lina: E para você isso é um jeito bom de estar em uma relação com pai e mãe?

Amanda: Não. 
Terapeuta Anna, Casal Luis e Ligia, Sessão 9

Ocorreu um momento da sessão em que Luis e Ligia conversaram entre eles, e as terapeutas ficaram na posição de escuta. Nesta conversa, Ligia foi fazendo perguntas para Luis, mas ele não as respondia. Houve um longo silêncio por parte dele ainda que a esposa tentasse conversar, e isso gerou uma grande tensão entre os dois, até que Luis olha para as duas terapeutas e diz que tem medo que a terapia "ferre tudo, ao invés de ajudar". Então, mudamos as posições de fala e escuta, e Anna e eu conversamos enquanto Luis e Ligia ficavam na posição de escuta.

Anna: Eu fico curiosa porque, assim, o que será? Será que Luis consegue fazer essa troca com outras pessoas?

Gabriela: Unhun.

Anna: Será que quando ele vai e conversa com a mãe dele, com o pai dele, ele consegue ter essa troca? Será que é só com a Ligia? Do que a Ligia fala, o que será que, às vezes, pode parecer para ele que precisa ficar guardando todas as ideias dele, não pode compartilhar. Aí ele fala, essa fala última, do medo do que pode acontecer na terapia, de "ferrar" tudo, que eu digo: "o que será, que ideia é essa?". Então, talvez, desse jeito que está então está bom? Melhor não mexer? A gente fica caladinho, cada um vai para o seu cômodo e é melhor não conversar, não trocar ideias? Se trocar ideias, o que que vai acontecer? Né? Parece que tem o medo de algo que pode acontecer. Então será que é por isso que guarda as ideias? Por medo? Eu fiquei com essas curiosidades.

Gabriela: Unhun.

Anna: E parece que, se falar... olha como é que veio essa pergunta no final, né? Parece que é assim: "é assim que eu sei conversar, ficando quietinho. Se a terapia vai mexer nesse jeito de eu conversar, eu tenho medo do que vai acontecer. Porque eu não sei o que pode acontecer nessa relação". Então melhor será deixar daquele jeito? Mas tem um pedido de querer ajuda, porque o pedido do começo da sessão é: "vai ter resultado? Que resultado?"

[...]

Anna: E, assim, a metáfora que a Ligia trouxe da viagem me fez muito sentido. Porque, se você sai para uma viagem, você tem um final. Você planejou sair daqui até São Paulo: "olha, nós vamos parar no posto tal para encher o tanque, para tomar uma água e ir ao banheiro". Depois você sabe que vai entrar no carro de novo e vai continuar, para chegar no objetivo combinado, né? $\mathbf{E}$ eu fiquei pensando que seria mais ou menos a terapia. Você busca, você se propõe a fazer terapia de casal porque você tem uma questão, o casal tem uma questão e quer olhar para isso. Aí você começa a viagem para isso e, de repente, parece que chega num lugar, numa paradinha, e ele fala: "peraí, eu não sei se vou até o fim, para chegar no ponto final que a gente planejou. É melhor voltar ou não mexer, não continuar a viagem". Será que é por aí que está? o que será que está passando?

Anna explora suas inspirações para o uso deste recurso:

Gabriela: O que você acha que poderia me ajudar a entender o que você está pensando? Porque você nomeia alguns padrões. 
Anna: A Sheila [McNamee]. [...] Da forma como nós coordenamos ações. Agora, Gabriela, de novo te digo, você está me perguntando agora e eu estou olhando isso aqui [aponta o material]. Você fala ao que me remete, o que me lembro nesse momento, é isso. É o que eu aprendi com a Sheila, inclusive no último workshop. E ela vem repetidamente mantendo essa linha dela, nos textos que eu tenho acompanhado. [...] Ultimamente, quando se fala em padrão relacional e comunicacional eu penso nas ações coordenadas, o que fazemos juntos, tá?

Anna descreve suas ações, após a leitura do material, a partir da inspiração na proposta de Sheila McNamee acerca dos processos de construção social. Para a autora, as realidades sociais emergem a partir a coordenação de ação entre as pessoas, no momento-a-momento da interação social (McNamee, 2014). São ideias que trazem um olhar mais voltado para a dimensão microssocial da interação humana, trazendo uma sensibilidade para a maneira como as ações e suplementações das pessoas em interação configuram a realidade da vida cotidiana (McNamee, 2004b). Cria-se um olhar sensível para os padrões, ordens morais e expectativas que vão sendo construídas na relação e delineando o que as pessoas sentem e descrevem como sendo "a forma como fazemos aqui". A autora afirma que o desafio do terapeuta que trabalha com estas ideias é centrar-se nos padrões de interdependência investigando como estes cenários são criados a partir da ação conjunta de todos os membros (McNamee, 2001).

Além desta perspectiva mencionada por Anna, é importante ressaltar que a exploração de padrões comunicacionais e relacionais fez parte da constituição do campo da TF. O estabelecimento do pensamento sistêmico ancorou-se na exploração de padrões, aspectos característico da cibernética de primeira e segunda ordem. Por exemplo, alguns textos clássicos voltados para a prática clínica abordavam a descrição e uso terapêutico dos padrões comunicacionais e relacionais das famílias como centrais para o terapeuta, trazendo o que, na cibernética de segunda ordem, passou-se a descrever como uma dimensão estética para a prática clínica (Bateson et al, 1956; McGoldrick, Gerson \& Petry, 2012; Selvini-Palazzoli, Boscolo, Cecchin \& Prata, 1986; Tomm, 1988; Watzlawick, Beavin \& Jackson, 2007)8.

\footnotetext{
${ }^{8}$ Embora tanto McNamee (2001, 2004b, 2014) quanto os autores sistêmicos citados utilizem a sensibilidade aos padrões relacionais como um orientador para a prática clínica, as ações do terapeuta em cada uma das perspectivas é distinta, como indicamos no capítulo introdutório.
} 


\section{f. Temática: Construir sentidos para além da queixa}

Nestas ações, ao escutar a queixa e os problemas que trouxeram as pessoas à terapia, Lina faz uma ampliação de sentidos para que os clientes consigam comunicar mais diretamente quais são seus desejos e pedidos tanto para as terapeutas, quanto para os membros da família.

Terapeuta Lina, Família Silva, Sessão 2

Como era a primeira vez que Amanda estava indo à terapia (ela faltara no primeiro encontro), conversávamos sobre os desejos de cada um para a terapia que estava se iniciando.

Renata: E eu queria falar algo também, que ela [Amanda] falou de confiança, né? Confiar mais em mim e no pai dela a respeito de contar as coisas...

Lina: Você gostaria que ela confiasse?

Renata: Gostaria.

Lina: Então nisso o seu desejo bate com o desejo dela [Amanda], porque ela está desejando confiar também.

Renata: É.

Lina: Então parece que vocês estão parecidas nisso.

Renata: Isso. Evitar de deixar para avisar as coisas de última hora, eu gosto que avisa com antecedência, eu não gosto que avisa de última hora, entendeu? Tem um compromisso e: "ai mãe, eu resolvi ir, vou agora", e a gente não está esperando. Principalmente no horário noturno. E respeitar os horários, porque tudo tem seu horário, sua hora. Porque tudo [brigas na família] surgiu por causa de confiança, por causa de horário. Então é isso que a gente queria que ela respeitasse mais eu e o pai dela. Não sair todos os dias e chegar tarde. Tem que respeitar e se cuidar, né? [...]

Lina: Então esses são pedidos que você está fazendo para a Amanda.

Renata: É.

Lina: $\mathbf{E}$ você acha que isso ajudaria nessa construção de confiança entre vocês.

Renata: É.

Terapeuta Lina, Casal Motta, Sessão 1

Vivian nos conta de uma diferença entre ela e Igor: enquanto ela se lembra de detalhes dos acontecimentos, Igor não se lembra. Ela afirma que isso lhe traz muito sofrimento.

Lina: Deixa eu ver se eu entendi. Você está dizendo que você guarda data, hora, vírgula, o que falou, e aí quando você fala essa questão de sofrer mais ou sofrer muito, você desconfia que guardar isso tudo de coisas doídas faz reviver o sofrimento.

Vivian: Isso [começa a chorar]

Lina: Você gostaria de poder deixar estas vírgulas, datas e horas?

Vivian: Sim. [...]

Lina: Você acha que este pode ser um pedido para a terapia?

Vivian: Sim. 
Na conversa terapêutica, diante daquilo que é trazido como um problema, Lina busca construir com os clientes um pedido direcionado às pessoas envolvidas ou ao processo terapêutico. Na interlocução com Lina, ela afirma que a construção de sentidos para além da queixa seria um "pedacinho" (sic) do caminho de construção de andaimes com os clientes, segundo a proposta de White (2012). Ela evidencia que, uma vez identificada a queixa por parte dos clientes, o foco seria explorar a maneira como cada um gostaria de ser. Neste sentido, seu lugar como terapeuta seria ajudar as pessoas a encontrarem os caminhos em que elas ficam mais próximas do que desejam. Também articulamos estas ações com a proposta de Vicente e Pereira (2001), em que a desconstrução da queixa e construção do pedido proporcionam uma mudança na posição ocupada pelo terapeuta em relação à família: de "especialista" em soluções para um parceiro que irá co-construir pedidos que contemplem e satisfaçam a todos os envolvidos.

\section{g. Temática: Abordar questões sociais e culturais que entrecortam o problema}

Esta temática refere-se a ações que levam em conta as dimensões social, cultural e histórica que fazem parte dos sofrimentos e dilemas humanos e, portanto, são intrínsecas à prática clínica (mesmo quando o profissional não leva em conta estes aspectos).

Terapeuta Anna, Casal Luis e Ligia, Sessão 8

Anna e Ligia começavam sua conversa, e Ligia afirma que a sexualidade é um assunto sobre o qual ela tem dificuldade de conversar. Retoma a queixa de Luis de que ela não toma a iniciativa para iniciar relações sexuais, e diz que isso é algo difícil para ela. Nos conta que, lendo um livro sobre sexualidade que Anna havia lhe emprestado, percebeu que isso é uma questão cultural "que vem lá de trás", em que "o homem é que domina essa área e a mulher é submissa”.

Anna: Aí, Ligia, pensar nessa perspectiva histórica, cultural, né? Eu fico pensando. Você acha que é uma questão sua, da Ligia?

Ligia: Acho.

Anna: A preocupação se vai iniciar ou não. É da Ligia essa preocupação?

Ligia: Então, lendo lá eu me identifiquei. 
[Ligia narra como ela pensava antes do casamento, e como pensa atualmente. Anna enfatiza essas diferentes formas de pensar sobre a iniciativa no sexo]

Anna: Por que eu estou indo por aí, né Ligia? Porque eu fiquei, já que você tocou nessa história de ter lido, né? E trazer essa perspectiva histórica e cultural, e fico pensando, né Ligia? Você acha que você é assim porque você é assim, ou porque você aprendeu a ser assim?

[breve pausa]

Ligia: Não, eu acho que eu aprendi.

Anna: Ahn?

Ligia: Sabe por que? Porque a gente é fruto da educação, da sociedade, do que a gente assiste, do que a gente ouve. Nós somos fruto do meio, né? Pode ser que em algum momento na sua vida você tenha pensado diferente, mas aí você ouve, ouve, ouve, ouve e aquilo vai... como se ficasse impresso, né? No seu inconsciente. E aí, quando você vê, você já está pensando como... você já está no senso comum, vamos dizer assim.

Anna: $E$ aí, você acha que pensando dessa forma, que a gente vai aprendendo, né? Você acha que é só você que pensa assim?

Ligia: Graças a Deus não. [risos]

Anna: Então, assim, quando você fala: "porque eu sou assim, isso é uma coisa da Ligia". Da Ligia e do... do...

Luis: Do resto do planeta.

Anna: do... do... do planeta feminino. [...] Mas, enfim Ligia. Era nessa questão que eu fiquei curiosa para saber se você acha que é só você que tem esse freio de mão, e que tem hora que vem a questão de ser recatada, de que não pode fazer certas coisas. Você acha que é só seu isso, ou você acha que tem... que você compartilha isso, que você imagina que outras mulheres também sintam isso?

Ligia: Não, eu acho que outras pessoas sentem. A autora lá, ela fala que as alunas delas passam por certas situações, que surgem essa questão de não aceitação, de ter bloqueio, vergonha, medos. Agora ela vai começar a discorrer sobre isso.

Anna: Então você viu que você não está sozinha, né?

É interessante notar que Ligia começa a conversa respondendo que suas vivências quanto à sexualidade consistem em uma questão dela como indivíduo. À medida que Anna segue a conversa trazendo a dimensão do aprendizado (aprender a ser assim), Ligia consegue ampliar a forma como entende sua relação com algumas questões da sexualidade, entendendo-as como fruto de uma cultura e da interação de elementos complexos - educação, sociedade, mídia.

Conversamos sobre este recurso na interlocução:

Gabriela: Eu achei interessante como você traz isso, de marcadamente fazer um corte de uma visão social em uma questão clínica [...] E tem alguma coisa com a qual você conversa quando você fica com essa preocupação de marcar isso?

Anna: Ah, então, é algo, assim, não tem como deixar passar certas coisas, né? Não tem como. Eu tenho horror de uma perspectiva individualista. [...] Eu não consigo ver outra 
maneira de eu estar ali. Para mim eu acho que é um posicionamento político, ético, acho que a terapia não pode ser nessa perspectiva individualista.

Gabriela: E aí quando você fala isso você conversa com... porque eu acho que a própria proposta do movimento construcionista, lá atrás, vem nessa crítica de olhar para o político, né? Para o político na clínica, e os movimentos feministas, etc. Você acha que é por aí que você vai quando...

A: Sim, o Murilo [Moscheta]. O Murilo fala bastante sobre isso. Eu conheci através do Murilo o pessoal da questão da terapia social. A Celiane Camargo-Borges. Pelo menos foi por onde eu poderia estar te citando em termos de autores, talvez eles que me apresentaram os "pais" deles, de alguma forma. Foi por onde eu conheci e faz muito sentido pra mim.

Segundo Camargo-Borges (2010), a terapia social é uma prática terapêutica que extrapola o nível individual dos problemas humanos, estando focada na construção de recursos coletivos para ação. As emoções são entendidas em um nível relacional, como fruto não apenas das relações mas também do processo histórico da humanidade. Assim, um dos objetivos da terapia social seria compreender os contextos sociais que tornam possível o surgimento de determinadas emoções.

Inspirada pelos pressupostos da terapia social, Anna constrói um direcionamento, na conversa com Ligia, que desnaturaliza as dificuldades como sendo fruto de questões individuais, levando a cliente a ver que suas dificuldades estão enraizadas em processos sociais que vão delineando experiências, sentidos e emoções em torno da sexualidade.

Descrevendo seu fazer, Anna denomina suas ações como fruto de um posicionamento político diante da terapia e ela não vê "outro modo de estar ali”. A este respeito, K. Gergen e Warhuus (2009) afirmam que a sensibilidade construcionista social para a prática clínica traz uma ênfase aos valores que qualquer postura carrega, entendendo que toda postura é ética e política em suas consequências. Considerando estes aspectos, o terapeuta encara a atividade clínica como politicamente engajada - nas palavras dos autores, "qualquer ação no seio de uma sociedade está simultaneamente a criar o futuro desta” (p. 39). Ainda neste sentido, Martins, McNamee e Guanaes-Lorenzi (2017) afirmam que, ao trazer a dimensão social para um contexto de conversa individual, o terapeuta dá forma a recursos conversacionais relevantes no contexto da prática clínica. Moscheta (2014) enfatiza, ainda, que o campo epistemológico configurado na ciência a partir das contribuições de Michel Foucault favoreceu a criação de “discursos científicos críticos 
e atentos às suas implicações" (p. 41). Entendendo a prática clínica sob este prisma, as ações de Anna trazem uma dimensão de uma terapeuta familiar que não busca ser neutra - contrariamente, está engajada em desconstruir narrativas opressoras, que transformam em uma questão individual os problemas que são de ordem social, coletiva.

\section{h. Temática: Fazer perguntas de futuro}

As perguntas de futuro estão focadas no que é desejado ou desejável para a família, a partir do que eles trazem como sendo situações que geram brigas, conflitos, sofrimento.

Terapeuta Lina, Família Silva, Sessão 4

Amanda nos conta sobre suas vivências na casa dos avós durante a infância e os bons sentimentos que permeavam sua relação com eles, contrapondo-a com 0 relacionamento conflituoso que tem com os pais.

Lina: Se você fosse recuperar essa possibilidade de criar uma relação com pai e mãe de um jeito desejado para você, de que jeito você gostaria que fossem estas conversas? Ou estes contatos, ou estas relações?

Amanda: É meio complicado, eu não sei como ia ser.

Lina: Você gostaria de ajuda para pensar nisso, Amanda?

Amanda: Sim.

Terapeuta Lina, Família Silva, Sessão 3

Renata contava-nos sobre suas preocupações quando Amanda fica trancada no quarto, momentos em que ela começa a pensar que a filha pode tentar cometer suicídio novamente. Mesmo que a filha diga que está bem, quando recebe uma "resposta seca" ela não consegue se livrar da preocupação.

Lina [falando com Renata]: "Resposta seca" como é que é?

Renata: [risos]

Lina [falando com Amanda]: Você sabe do que sua mãe está falando, Amanda? "Sim" ou "não" é uma resposta seca?

Amanda: Deve ser, eu acho que é só isso.

Lina: Tá. De que jeito que você acha que poderia responder para ela quando o seu quieta é um "quieta bem"? Para deixar ela bem também, e ela não entrar nesse movimento que ela falou que tem medo, de ficar perguntando e virar uma chata.

Amanda: Eu não sei. Ela pergunta e eu respondo, só. 
Lina: Sim, e ela está dizendo que se for uma resposta seca ela vai continuar na dúvida. Aí eu estou pensando, se você desejasse que ela não ficasse na dúvida, mas que ela ficasse tão bem quanto você, como você poderia dizer para ela?

Amanda: [breve pausa] Eu ia falar que está bem, que não tem nada de errado.

As perguntas de futuro convidam as pessoas a imaginarem cenários ainda não visitados por elas mas que podem se tornar formas desejáveis de viverem juntos, como ilustra o primeiro trecho apresentado. O cotidiano conturbado e conflituoso na relação entre pais e filha é colocado de lado por alguns instantes, e uma possibilidade de vida mais amorosa, carinhosa e confortável torna-se tópico de conversa. Este movimento em direção ao futuro pode proporcionar uma ousadia maior para pensar em possibilidades e saídas para os dilemas, visto que ainda estamos no plano da imaginação, sem um forte comprometimento em colocar em prática as ideias levantadas.

Uma outra dimensão relevante no uso das perguntas de futuro é a corresponsabilidade na construção tanto dos conflitos quanto das possibilidades de resolução, em direção a relacionamentos mais prazerosos. O segundo trecho ilustra este aspecto, em um momento no qual Lina evidencia que Amanda é corresponsável pela construção desta mãe "chata" que fica fazendo a mesma pergunta várias vezes. Ao mesmo tempo, Lina corresponsabiliza a mãe por conseguir dizer, mais diretamente, quais tipos de respostas não lhe satisfazem e quais podem deixa-la mais segura quanto à possibilidade da filha estar pensando em cometer suicídio. Com este foco de exploração, as respostas trazidas por cada membro podem se tornar alvo de ações concretas por parte de cada um.

McNamee (2004b) descreve alguns recursos para a prática terapêutica e, dentre eles, está o foco no futuro. A autora afirma que conversas sobre o futuro enfatizam o caráter relacional da construção de nossos mundos, uma vez que permitem à família, em conjunto com o terapeuta, envolver-se em construções situadas e colaborativas de novas formas de vida. Lina, ao construir conversas que enfocam o futuro, presentifica esta dimensão colaborativa e corresponsável na criação da mudança, convidando as pessoas a imaginarem-se vivendo diferentemente suas relações, de forma mais libertadora.

$\mathrm{Na}$ interlocução com Lina, ela afirma que a ideia de construir andaimes com a família perpassa suas inspirações para fazer este tipo de perguntas para os clientes. Ela diz que este conjunto de ações poderiam ser nomeadas como "empoderamento", 
consistindo em uma maneira de permitir que a pessoa fique "mais próxima daquilo que ela identifique como sendo o melhor dela" (sic). A construção de andaimes (White, 2012), assim, perpassaria esta orientação de Lina, que ocupa-se em dar contornos mais precisos ao que cada pessoa deseja ser e quais seriam as mudanças nas relações, para que, colaborativamente, possam criar recursos para colocar em ação estes desejos ou, em outras palavras, este desenho de um futuro mais prazeroso.

\section{i. Temática: Fazer perguntas reflexivas}

As perguntas reflexivas convidam o outro a pensar sobre si mesmo, sobre si mesmo na relação e/ou sobre relações (mesmo aquelas em que a pessoa não está envolvida mas que, de algum modo, afetam-lhe).

Terapeuta Anna, Casal Luis e Ligia, Sessão 6

Em dado momento, Luis conta que, antes de ir à sessão seguinte da terapia, perguntou a Ligia o que ela iria falar na próxima sessão. Em resposta, Ligia ficou muda. Ele narra este acontecimento em um tom inconformado uma vez que Ligia constantemente reclama que eles "não conversam". Anna explora com Ligia as razões pelas quais ela emudeceu ao ouvir a pergunta. No diálogo a seguir, Anna conversa com Luis acerca do ocorrido.

Anna: [falando com Luis] Então, e aí eu fico pensando se tem ideias que você gostaria de estar compartilhando com ela. Porque se você gostaria, eu fico pensando, é porque tem algum desejo de poder conversar alguma coisa com ela...

Luis: É, porque assim...

Anna: ... quando eu pergunto alguma coisa, igual, eu estou aqui com vocês, né? Eu fico pensando em mim. Eu faço perguntas, né, quase que o tempo inteiro. Porque a partir de pergunta que a gente vai conversando...

Luis: E, porque somos só nós dois. Se eu não conversar com ela, eu vou conversar com quem?

Anna: Então, e aí eu fico pensando: se você pergunta, você está esperando uma resposta, no mínimo [ênfase na entonação].

Luis: É, claro que eu estou esperando.

Anna: Ou negativa, ou afirmativa, ou reflexiva.

Luis: Isso.

Anna: A gente aqui conversando, eu acho que se a gente chegasse aqui e ficasse quietinho... eu não sei. Como é que vocês iriam se sentir se eu não fizesse perguntas para vocês?

Luis: Ah, eu já teria parado. 
Nesse trecho, entendemos que Anna conversa com Luis mas suas perguntas e comentários são dirigidos à Ligia. Isso proporciona a criação de um espaço de conversa em que a esposa pode ouvir a pergunta sem a obrigação de responde-la imediatamente, uma vez que, na interação anterior em que Anna indagou-a sobre as razões pelas quais ela não respondeu, Ligia defendeu seu ponto de vista sem perceber que estava agindo de forma contrária ao que é, exatamente, sua principal queixa em relação ao marido e ao casamento - eles não conversarem. Anna, indiretamente, convida Ligia a refletir: ao ouvir uma pergunta, por que não respondeu? Mas isto é feito sem que a cliente precise responder em voz alta - basta que ela reflita sobre o acontecimento.

Neste momento da sessão, Anna convida o casal a imaginar um cenário em que chegam na terapia com óbvias expectativas de conversar e encontram uma terapeuta emudecida. Criando este cenário, ela espelha na relação terapêutica o acontecimento entre o casal, deixando-os frente a frente com o que parece ser o seu dilema: eles queixam-se de que não conversam e procuram a terapia para cuidar desta questão; contudo, quando um deles propõe iniciar uma conversa, o outro emudece. Assim, o que nos permite afirmar que a pergunta é reflexiva envolve diferentes aspectos: as afirmações que "preparam" o momento de enunciação da pergunta reflexiva, ao final do trecho; o fato de estar falando com Luis mas endereçando-se à Ligia, que ouvia atentamente a conversa; e a intenção, por parte de Anna, de provocar uma reflexão na esposa.

Terapeuta Lina, Casal Motta, Sessão 1

$\mathrm{Na}$ primeira sessão, quando começamos a falar com Vivian sobre as emoções que surgiram enquanto ela contava histórias sobre sua mãe, percebemos que Igor também fica emocionado e começa a chorar. Exploramos com ele esta emoção, e ele diz que agiu de forma muito "imatura" com a sogra, dando-lhe as costas no momento em que ela mais precisou (durante seu adoecimento). Enfatiza o quanto a sogra os acolheu no início do casamento, quando foram morar em sua casa, e mesmo assim ele não teve paciência com ela no final de sua vida, enquanto as lágrimas escorrem pelo seu rosto.

\section{Lina: E tinha como este rapaz de 20 anos olhar com os olhos de hoje?}

Igor: [breve pausa]. Não [breve pausa]. Não. Mas eu acho que tinha como você ter um pouco mais de discernimento, né? Porque 20 anos você não é moleque mais.

Lina: Você ainda não tinha vivido essas coisas na sua vida?

Igor: Não. Não.

Lina: Unhun. Você teve alguém que te orientou?

Igor: Não. Eu não tive orientação nenhuma de nada. De nada. Única orientação que eu tive foi quando eu falei pra minha mãe que ela [Vivian] estava grávida, e mesmo assim ela disse: "você não tem que casar, não vai casar não". E eu falei: "como não? Meu filho 
vai nascer sem pai? Não!”. Foi a única orientação que eu tive: “não vai casar. Não, não, não, não". Então já começou o atrito lá dentro nesse sentido, entendeu?

Lina: Então deixa eu ver se eu estou entendendo, Igor. Parece que você conta que quando, no hoje, você lembra disso, você vê naquele rapaz imaturidade, vê falta de... compaixão que ele falou?

Gabriela: Gratidão, né?

Lina: Falta de gratidão. Mas quando você vai lá naquele rapaz e olha em volta dele e o que ele tinha, ele não tinha orientação, ele não tinha alguém que o ajudasse a perceber estas coisas, né? E parece que teve que, inclusive, frente àquilo que recebia, fazer um movimento contrário. Porque quando você tem a orientação "não precisa casar", parece que esse rapaz usa de discernimento para falar: "Não, eu quero que meu filho nasça com pai”.

Igor [chorando]: Para você ter uma ideia de como é que estava.

Lina, sensível às emoções profundas e o tom que nos parece ser de extrema auto-exigência e autopunição por parte de Igor, oferece-lhe uma nova lente pela qual olhar para seu passado. Em tom de suave acolhimento, Lina pontua que um jovem não pode viver sua vida com a experiência de um homem de mais de quarenta anos somos o que somos, nem mais, nem menos. Diante da postura de persistente autopunição, Lina procura nas relações de Igor pessoas ou situações que poderiam ter-lhe trazido um olhar diferente sobre a relação com a sogra no momento de seu adoecimento, e o que aparece é a conturbada relação com sua mãe e a necessidade que ele teve de transgredir suas orientações para seguir seus próprios valores.

Este caminho de explorações e comentários da terapeuta oferecem um novo olhar sobre as escolhas e sentimentos de Igor no passado, contextualizando-os nas relações e valores em que ele estava imerso naquele tempo. Convida Igor a refletir sobre quem ele era e em quais relações estava imerso no passado, esvaziando a ideia de que poderia ter havido uma má intenção na relação com a sogra. O tom de acolhimento da terapeuta parece abrir espaço para que o Igor do presente acolha o jovem que foi e as situações difíceis que viveu. E a escuta desta conversa, por parte da esposa, também abre espaço para uma reflexão e ressignificação das ações do marido em relação à sua própria família no passado pois estas a influenciavam diretamente.

Acerca do uso de perguntas reflexivas na terapia, Tomm (1988) afirma que este tipo de pergunta encoraja os clientes a mobilizarem seus próprios recursos na solução de problemas. O terapeuta interage para ajudar a família a abrir novas possibilidades e perspectivas, ao mesmo tempo em que entende que cada membro vai mudar a seu tempo. Na definição do autor, as perguntas reflexivas são formuladas para fazer o cliente refletir sobre as implicações de suas percepções e ações atuais, e considerar 
novas opções. Na análise das perguntas reflexivas de Lina e Anna, consideramos aspectos relacionais incluídos nas perguntas, as quais têm a preocupação primordial de provocar reflexões para que a pessoa pense sobre si mesma, sobre si mesma em relação com o mundo e com outras pessoas, e sobre as relações que distingue ao seu redor.

Na descrição dos processos reflexivos, Andersen (2002) destaca que a principal contribuição que o terapeuta pode oferecer à conversa é fazer as perguntas que os clientes não se fazem e que podem abrir possibilidades de construção de novas respostas e novas maneiras de sentir e agir. Para ele, os clientes sentem-se imobilizados quando experienciam os problemas e sofrimentos sem encontrar uma forma de enfrenta-los. Esta paralização advém do fato das pessoas se fazerem sempre as mesmas perguntas. Assim, quando o terapeuta contribui para a criação de novas compreensões, por meio de perguntas, ele precisa, inicialmente, fazer duas perguntas para si mesmo: como formular perguntas incomuns? Como criar a possibilidade de que cada pessoa comece a se fazer novas perguntas? Neste sentido, vemos que o processo reflexivo que buscamos construir com os clientes começa conosco, nas perguntas que fazemos a nós próprios, como terapeutas, acerca da conversa em curso.

Consideramos importante destacar uma ressalva, neste tema das perguntas reflexivas. A nosso ver, o que define se uma pergunta é reflexiva não é meramente a intenção do terapeuta ao fazê-la, mas o efeito que ela provoca na conversação e na forma como as pessoas pensam e agem em relação ao assunto em questão. Vê-se, assim, o quanto foi desafiador distinguir estas ações como uma temática à parte, no conjunto dos dados, e construir sua definição. Para tanto, buscamos enfatizar os efeitos que as ações das terapeutas tiveram nos clientes e na continuidade da terapia, indicando que a reflexão não estava contida na pergunta em si, mas no que ela provocou nos clientes.

\section{j. Temática: Fazer comentários reflexivos}

Os comentários reflexivos, à semelhança das perguntas reflexivas, propõem novas perspectivas sobre as pessoas e as pessoas em suas relações, convidando os clientes a pensarem sobre si mesmos sob um ponto de vista relacional, mais 
complexo e inclusivo de novas nuances, que possam gerar maneiras diferentes de olhar para as situações em questão.

Terapeuta Anna, Casal Luis e Ligia, Sessão 8

Anna e Ligia conversavam sobre a época do namoro do casal e a construção da intimidade entre eles. Anna explora os momentos em que Luis foi conquistando Ligia e ela foi se abrindo para confiar nele.

Ligia: E aí, eu acho Anna, que a gente... como é que eu vou dizer? Os problemas que não são sexuais foram se sobressaindo. Porque aí a gente mudou o foco, talvez, do namoro. Porque aí a gente casou, aí vieram outras responsabilidades, e aí vieram os problemas, aí a gente...

Anna: As obrigações...

Ligia: As obrigações. Porque quando a gente namora, não sei, tem uma coisa no ar que é diferente, né? Que você não tem uma casa para cuidar, a gente não tem aquelas obrigações, assim. É namorar, é sair, é passear...

Anna: Mas assim, né Ligia. É... pelo que vocês contaram para a gente, da história de vocês, vocês fizeram, vocês construíram bastante coisa juntos... Ligia: Sim.

Anna: Parece que vocês tiveram projetos em conjunto, né? E vocês de fato realizaram os projetos em conjunto.

Ligia: Unhun.

Anna: E aí passaram por várias histórias, como qualquer pessoa, né? A vida vai passando, eu falo que o livro vai engrossando, são vários capítulos de histórias da nossa vida.

Ligia: É.

Anna: Mas vocês estão em um momento, também, que me parece que estão olhando para a relação de vocês, se propondo a rever como é que vocês estão, se propondo a ficarem juntos, a se curtirem. Então talvez seja o momento de agora... parece que é o desejo de vocês, inclusive, de resgatarem algumas coisas que talvez tenham ficado em um outro momento. E resgatarem coisas que vocês dois falam com muito gosto, com muito desejo, com muito carinho. Tem lembranças muito boas. Quiseram, escolheram ficar juntos e parece que tem o desejo de resgatar aqueles momentos, essa intimidade que foi boa para vocês dois. Então, assim, porque não chegar num momento e redescrever, e revisitar, e... reeditar essa relação, esse casal. Porque não é um casal casado e namorado?

Ligia: É.

Anna: Né? São coisas que às vezes a gente não para pra pensar. Por que o casal casado não é mais um casal namorado? $O$ que precisa acontecer para ser um casal de namorados? Né? Ainda mais que vocês são livres, não têm filhos dependentes, e estão muito bem e prontos para viver e curtir a vida [risos].

Ligia: Então!

O comentário reflexivo de Anna revisita a relação do casal e reconta sua história, seus percursos, suas escolhas e as conquistas que atingiram ao longo dos quase vinte anos de união. Essa nova perspectiva busca ser uma inspiração para que o casal faça o mesmo em suas vidas: reeditem sua própria história e retomem os aspectos gostosos 
da vida de namorados. Entremeando seu comentário com perguntas reflexivas, Anna indaga sobre o que precisaria acontecer para que isso se torne possível, proporcionando um espaço de criatividade e reflexão acerca da vida de Luis e Ligia no futuro. Na postura de ouvinte desta conversa, Luis também pode refletir sobre essas questões sem precisar responder diretamente à terapeuta. Nos meses seguintes, Ligia referiu-se diversas vezes a esta ideia.

Terapeuta Lina, Casal Motta, Sessão 8

Iniciamos a sessão perguntando ao casal se haviam conseguido cumprir os combinados durante a semana, considerando o fato de ter havido violência física entre eles na semana anterior. Vivian diz que já estão acostumados a ficar mais distantes quando há este tipo de brigas, mas que Igor voltou a dormir no quarto do casal na quinta-feira (sendo que o combinado era que ele dormisse na sala a semana toda). Lina pergunta o que ela pensa sobre este desenrolar, e Vivian diz que é "normal, da mesma forma como acontece das outras vezes". Na conversa, vemos que ela percebeu que Igor não estava cumprindo o combinado e não apontou isso para o marido para "não causar um desconforto". Na sequência da conversa, Vivian começa a chorar e diz que não gostaria de Igor pensasse que ela não o quer mais ali. Lina pergunta se ela quer Igor ali, Vivian diz que sim. Eu entrego lenços de papel para Vivian e Lina e eu começamos a conversar.

Lina: Gabi, eu acho que isso é interessante. Porque eu acho que quando a Vivi fala que quer ele ali, eu acho que é a questão da gente voltar a pensar como a gente vai trabalhar - pelo menos com ela, não sei com o Igor, a gente vai ver com ele - porque ela fala dessas ambiguidades que ela entra. E ambiguidade é uma coisa que é difícil para cada um de nós lidarmos, né? Gabriela: Unhun.

Lina: É difícil para a gente lidar. Agora, quando a gente oferece para o outro também fica muito mais difícil para o outro lidar com as nossas ambiguidades. $O$ querer, não querer. Então, acho que isso a gente pode deixar recortadinho aí, para depois que a gente ouvir o Igor, a gente voltar a trazer isso.

Gabriela: Sim. Unhun.

Lina: E só estendendo um pouquinho, porque o que me preocupa nisso é que, se gente não olha para a ambiguidade como uma coisa que nasce na gente e que a gente comunica, fica parecendo que tem uma outra pessoa que não está fazendo o que a gente quer. Quando na verdade a gente está querendo duas coisas. Faz sentido?

Gabriela: Sim.

Lina: E aí me preocupa isso, quando eles podem entrar nessa ideia de que é o outro que não está fazendo uma coisa que deveria fazer.

As ações de Lina exemplificam uma forma de fazer comentários reflexivos utilizando a co-terapia como um recurso: os comentários são feitos em uma conversa com a co-terapeuta mas endereçados aos clientes. À época da terapia, o casal vivia uma situação de constantes separações e brigas envolvendo violência física e 
psicológica, com o concomitante desejo de permanecerem casados. Tocando neste tema delicado, Lina utiliza o recurso de conversar com a co-terapeuta sobre a complexidade que envolve estas questões, em tom leve e delicado, como uma forma de introduzir novas nuances para este tema e seguir explorando posteriormente em uma conversa com o casal. Interessantemente, após esta conversa, Vivian descreve a si mesma como "ambígua" na relação com Igor, e traz a ambiguidade como aspecto fundamental que alimenta o repetido movimento do casal: constantes brigas que são seguidas do desejo de permanecerem juntos.

$\mathrm{Na}$ interlocução, comentários de Anna elucidam sobre a forma como ela vê o uso deste recurso:

\begin{abstract}
Anna: Porque é aquela coisa do adequada... como é que é? Gabriela: Adequadamente incomum?

Anna: É. Ou só do comum. Também, até que ponto que a gente vai e fica só ali, ou até que ponto a gente oferece, insiste, convida para mais outras coisas. Que é bem tênue, né, sinto, esse nosso lugar de terapeuta. Então também, ficar só no que ela está me mostrando[...] a gente fica no problema, a gente encaixa na história dominante. E aí, como é que a gente vai buscar histórias subordinadas para poder enriquecer e para poder transformar alguma coisa, fazer uma diferença.
\end{abstract}

$\mathrm{Na}$ descrição dos pressupostos que embasam sua proposta, Andersen (2002) descreve o conceito de informação proposto por Bateson. Para ele, quando definimos algo como sendo diferente do meio, estamos distinguindo este elemento como uma informação relevante. Em outras palavras, este elemento surge em nossa percepção como uma "diferença que faz diferença" e passa a fazer parte das imagens que utilizamos para dar sentido ao mundo (Andersen, 2002). O autor define três tipos de diferenças, que podemos entender como três formas pelas quais as informações podem ser classificadas: uma diferença comum, que não produz mudança, não adquire relevância como informação; uma diferença adequadamente incomum, a qual introduz novos elementos que podem produzir mudanças; e uma diferença incomum demais, que introduz elementos tão inusuais que parecem ameaçar a integridade do indivíduo, que se fecha para não ser influenciado. Andersen (2002) enfatiza que o terapeuta deve estar atento a estes elementos em uma conversa, para 
compreender o que pode ser adequadamente incomum para cada interlocutor a quem nos dirigimos.

Anna lança mão deste conceito para descrever suas ações, entendendo que suas reflexões buscam oferecer diferenças adequadamente incomuns para Ligia e Luis, potencialmente trazendo a possibilidade de criarem uma nova forma de entender e lidar com seu momento atual de vida. O tom de leveza e humor com que estas reflexões são oferecidas parecem torna-las mais "palatáveis", aumentando a possibilidade de chegarem ao casal como diferenças adequadamente incomuns.

Lina, semelhantemente, oferece ao casal um novo termo a partir do qual as ações de Vivian (e, possivelmente, de Igor) podem ser nomeadas: ambiguidade. $\mathrm{O}$ tom de voz de Lina, no momento destas falas parece carregar um acolhimento, criando um espaço de legítima continência para a difícil maneira como Vivian enfrenta os sentimentos opostos que nutre na relação com Igor. O contexto que é criado pelo conteúdo das reflexões e também pela forma como elas são trazidas pela terapeuta parecem convidar o casal a refletir diferentemente sobre sua relação, agora a partir da ideia de ambiguidade. Surgindo a diferença na forma de falar, pensar e sentir, que vemos a partir da mudança na forma de Vivian entender e falar sobre sua relação com Igor, vemos que a informação foi adequadamente incomum.

\section{k. Temática: Fazer um reenquadramento}

Nesta temática, entendemos o reenquadramento como a oferta de uma nova perspectiva sobre o que é dito - um novo enquadre - que torna mais complexo e relacional o panorama trazido pela família.

Terapeuta Lina, Família Silva, Sessão 2

Amanda havia nos contado sobre sua infância morando na casa dos avós, e o quanto a relação com estes era baseada na segurança, amor, confiança. Quando Amanda para de falar, Renata diz que gostaria de dizer algumas coisas em relação ao que a filha contou, e, parecendo incomodada, faz alguns apontamentos que parecem "corrigir" as percepções da filha: a mãe não estava "ausente" ou simplesmente "entregou a filha para ser criada pela avó", mas sim estava trabalhando para ajudar no sustento da casa.

Lina [falando com Renata]: E aí, veja se faz algum sentido para você o que eu vou dizer. Você era mãe, era uma adulta que estava trabalhando e você sabia porque estava fora de casa. 
Renata: Unhun.

Lina: Você acha que ela como uma criança, menor de 7 anos, conseguia ter a mesma percepção que você, ou para ela o que você estava fazendo era simplesmente não estar com ela?

Renata: Isso. Foi isso que eu entendi. E para ela entender, porque hoje em dia o casal trabalha. Porque antes, há muito tempo atrás, o marido trabalhava e a mulher ficava em casa. Mas ali nós dois trabalhávamos fora.

Lina: Agora, cabe para você a percepção que ela teve na época, a partir dos olhos que ela tinha para ver?

Renata: Unhun.

Lina: Cabe isso?

Renata: Unhun.

Lina: Não que essa era toda a verdade. Mas que a forma como ela sentia era assim: quem está cuidando aqui de mim é a minha avó.

Neste trecho, ao nos relatar as vivências de infância na casa da avó, em tom de saudade e marcando uma clara preferência pela avó em detrimento dos pais, Amanda afirma enfaticamente que foi "criada pela avó" (sic), e segue narrando algumas lembranças deste tempo. Enquanto Amanda fala, Renata aparenta estar incomodada e ansiosa por falar. Quando Lina lhe dá voz, ela faz comentários que parecem corrigir a percepção de Amanda e trazer luz aos fatos, oferecendo-nos um relato "do que realmente aconteceu”. Lina, assim, intervém no sentido de ir construindo com Renata um quadro em que torna-se possível e legítima a percepção construída por Amanda, de que era uma criança que sentia a falta da mãe e passava a maior parte do tempo na companhia da avó, que foi constituindo-se como figura central e uma relação de apego e carinho para a neta. Do lugar de "errada”, Amanda é enquadrada no lugar de uma criança que agiu conforme seus sentimentos e suas possibilidades de compreensão. Ao mesmo tempo, Lina legitima Renata quando esta afirma que estava trabalhando porque precisava (e não porque escolhia estar longe da filha). Neste movimento, Renata passa do lugar de "ausente" e possivelmente "negligente", para o lugar de uma mãe que precisava trabalhar para prover o sustento da filha. A terapeuta, assim, acrescenta nuances nas descrições de mãe e filha, tornando suas posições menos polarizadas e mutuamente excludentes.

Terapeuta Lina, Casal Motta, Sessão 1

Logo no início da sessão, Lina e eu sugerimos que comecemos a conversa conhecendo um pouco da história do casal. Já havíamos feito com o casal o combinado de um não interromper enquanto estivéssemos falando com o outro. Lina começa pedindo que Igor nos conte um pouco sobre há quanto tempo estão juntos, quanto tempo de namoro, casamento, filhos. Ele responde: 
Igor: Nossa... É, esse... esse início de tempo aí eu sou meio perdido.

Vivian: [risos]

Igor: Minha cápsula do tempo acho que deu pane.

Vivian: Eu sei. Posso falar? Depois ele continua.

Lina: Espera só um pouquinho [falando com Vivian], eu fiquei até curiosa. Na sua

perspectiva [falando com Igor], na sua cápsula do tempo... [rindo]

Gabriela: [risos]

Igor: Não... tivemos dois anos de namoro. Não, não foi dois anos de namoro, foi menos.

Casamos... há... eu lembro por causa da minha filha, senão poderia passar batido.

Lina: Tá...

Igor: Ela [Vivian] mesmo fala: "você não tem noção de tempo".

Lina: Ou talvez o tempo não seja um elemento tão importante assim na hora de pensar a relação, para você.

Igor: Não, não é só a relação, isso é num contexto geral também.

Lina: Tá. Talvez você priorize outras coisas.

Na conversa com Igor, Lina o reposiciona quanto a não guardar informações sobre algumas datas que, geralmente, considera-se importante na construção de uma narrativa cronológica da vida. Na medida em que não se alia à ele em sua autodescrição como alguém que "não tem noção de tempo", Lina redescreve a relação com o tempo a partir de outros critérios que podem ser igualmente importantes nas narrativas da vida. Igor é reposicionado de um lugar de inadequação para o enquadre de alguém que possui critérios de importância que o diferem do que costuma ser importante para as outras pessoas. Ao mesmo tempo, Lina reposiciona Vivian quando não lhe dá espaço para responder estas questões por Igor: de alguém que parece ocupar o lugar de "memória externa" do outro, para uma pessoa que pode participar de uma conversa como ouvinte e deixar o outro ser ele mesmo, sem a necessidade de ser interrompido por alguém que pode falar por ele.

Ao apresentar o reenquadramento como técnica para a prática de TF, Minuchin (1990) afirma que toda família "enquadra" cada membro em um lugar único, o qual situa e identifica este membro no grupo familiar. Estes lugares de cada um são continuamente sustentados na dinâmica do grupo familiar, de forma relacional e recíproca, e é nesta continuidade que os enquadres ganham força para modelarem as experiências identitárias de cada pessoa, e da família como um todo. Nas ações de Lina, a terapeuta não se alia às descrições que são feitas e aos lugares em que cada membro é posicionado, oferecendo uma nova visão e, portanto, novas possibilidades identitárias para os envolvidos. Assim, o reenquadramento não é meramente trazer uma outra versão sobre o que foi dito - é isto que Renata faz quando busca "corrigir" 
a percepção da filha e trazer o seu ponto de vista sobre as vivências do passado. Estamos propondo que reenquadrar é tornar as descrições mais amplas, complexas, dando-lhe novas nuances que eliminam a polarização de versões e posicionamentos para oferecer um sentido que convide as pessoas a se acolherem e legitimarem, com novos horizontes possíveis para as possibilidades de ser de cada um. Na conversa de interlocução, Lina refere-se ao reenquadramento quando descreve a influência do conceito de andaimes (White, 2012) em sua prática:

Lina: [...] Olha, de forma indireta, eu acho que o "Reenquadramento", "Diretivas", mas eu acho que é de forma indireta [que há a busca pela construção de andaimes].

Gabriela: Por que indireta, como assim?

Lina: Porque eu acho que quando a gente faz reenquadramento, por exemplo, aquilo que ela [Vivian] fala que ele [Igor] não presta atenção nas datas... e aí a gente fala que talvez ele esteja... não lembro.

Gabriela: Tem outros parâmetros... que talvez esse não seja um parâmetro tão importante pra ele.

Lina: É, alguma coisa assim. Eu acho que convida o olhar diferente. Mas entre o olhar diferente e transformar isso em ações, ahn, eu acho que não necessariamente a pessoa vai conseguir fazer sozinha. [...]

Gabriela: Anhan. No sentido de que há um reenquadramento mas não necessariamente há uma mudança nessa posição ou na relação?

Lina: É... algumas pessoas eu acho que vão sozinhas. Tem gente que você oferece uma coisinha e reconfigura tudo. Eu não sei o que acontece, isso me chama bastante atenção. Que eu acho que tem a ver com processos tanto metacognitivos quanto metaemocionais [risos] não sei o que é. Agora outras pessoas parecem que estão muito no concreto, assim. Se você não vai junto: "isso acontece em mais alguma coisa? O que mais que acontece? O que você poderia ver disso?" e tal, parece que a pessoa não consegue ir. $\mathrm{E}$ eu acho, aí entra essa questão ética, eu tomo como obrigação do terapeuta, ele ir junto a menos que o cliente diga pra ele que não quer que ele vá junto. [...] Aí estou conversando com os andaimes do Michael White.

Gabriela: Então que andaime que a gente pode ir construindo? Como que você conversou com isso?

Lina: Isso. Isso. O que me ajudaria a formar um andaime que dá uma sustentação em que o outro pode se sentir seguro para ir, ajudando o outro a chegar onde eu desejo que chegue.

Lina chama a atenção para um aspecto crucial na construção de um contexto terapêutico: a mudança nas formas de descrever (ou enquadrar) não geram, 
necessariamente, uma mudança nas formas de agir e sentir. Em outras palavras, a transformação nas formas de descrever a si mesmo, os outros, os eventos e vivências não necessariamente gera, como consequência, uma diferença nos relacionamentos, em como as pessoas se sentem e se posicionam umas em relação às outras. Neste aspecto, Lina entende que o terapeuta deve colocar-se lado a lado do cliente, construindo paulatinamente os degraus que permitirão reconfigurações tanto nas dimensões explicativas quanto emocionais e relacionais da vida das pessoas, trazendo diferenças em seu modo de agir.

\subsubsection{Categoria: Ações de construção da comunicação em contexto}

As ações de construção da comunicação em contexto compõem uma categoria em que as ações estão voltadas para a construção do contexto conversacional e podem trazer reflexões sobre os efeitos da comunicação desenvolvida em terapia. Inclui três temáticas, apresentadas no quadro 7.

\begin{tabular}{llc}
\hline Categoria & Temáticas & Terapeuta \\
\hline $\begin{array}{l}\text { Ações de } \\
\text { construção da } \\
\text { comunicação } \\
\text { em contexto }\end{array}$ & Coordenar a conversa & Anna e Lina \\
& Metacomunicar & Anna e Lina \\
& $\begin{array}{l}\text { Utilizar a co-terapia como recurso para a } \\
\text { comunicação }\end{array}$ & Anna e Lina \\
\hline Quadro 7. Temáticas que compõem a categoria “Ações de construção da comunicação em contexto"
\end{tabular}

\section{a. Temática: Coordenar a conversa}

A coordenação da conversa é parte essencial do trabalho do terapeuta. Envolve a atenção ao estilo comunicacional da família - quem fala, quanto fala, quem interrompe quem, quem fala mais ou menos do que quem, quem fala por quem, etc. Estas sequências de interação indicam as poderosas teias invisíveis que tecem a vida 
da família, indicando caminhos para exploração de questões como hierarquia, poder, alianças, segredos, dependência/independência, violência, resiliência e outros aspectos da vida familiar.

Atentas à estas informações e suas funções na vida e na comunicação da família e do casal, as terapeutas fazem escolhas e atuam no fluxo comunicacional em busca de tornar a conversa distinta daquelas que os clientes habitualmente têm em sua vida cotidiana. $\mathrm{O}$ trecho de um atendimento com Lina exemplifica essa ação.

\begin{abstract}
Terapeuta Lina, Casal Motta, Sessão 7
Logo no início da sessão, o casal nos conta que houve uma briga entre eles envolvendo violência física. Vivian falava conosco muito rapidamente, sem pausas, chorando, conversando em tom de muita raiva. Ela fala desta forma por vários minutos enquanto nós três - terapeutas e Igor - apenas escutamos. Após um tempo, Lina tenta interrompê-la algumas vezes, mas ela não para de falar.
\end{abstract}

Lina: Vivi, desculpa, eu vou ter que te interromper de novo.

Vivian: [suspiro] Tá. Unhun.

Lina: Apesar de perceber que você está precisando muito de um espaço para falar.

Vivian: [diversos suspiros profundos enquanto Lina fala]

Lina: Mas é que eu estou vendo que tem coisas que você está falando e que é menos para nós e mais para ele, como se fosse um jeito de dar a sua versão para ele. E aí a gente fica meio que perdida, sem saber exatamente o que está acontecendo, e aí a gente não pode ser útil desse jeito. Tá? Então, eu acho que.. ahn... deixa eu conversar um pouquinho aqui com a Gabriela para a gente pensar em alguns rumos.

Vivian: [suspira profundamente]

Neste trecho, Lina interrompe a fala de Vivian ainda que perceba sua necessidade de falar - e, falando abertamente sobre isso, marca sua posição como alguém que precisa cuidar da forma como ocorre a conversa na terapia. Em suas ações, Lina torna evidente as posições que cada pessoa está assumindo na conversa que estava acontecendo quando Vivian falava ininterruptamente. Em nossa interlocução, Lina comenta sobre o uso deste recurso:

Lina: Então eu me vejo muito interventiva com eles, assim, recortando bem o espaço de fala, pra não correr risco de falar... de dar vazão para a impaciência que eles vão ficando em determinados momentos [...] sabe, naquela coisa de torear? Né? De dar a palavra, mas não pra qualquer coisa. [...] Eu acho que deve ser uma coisa meio que geral em mim, quando tem essa 
diferença de poder, ou risco de uma violência que continua e tal...[...]

Gabriela: [...] E quando você fica com vontade de fazer, de ir por esses caminhos, dialogando com essas ideias, você falou do Karl Tomm, do posicionamento, isso me dá a ideia também de um pressuposto seu de estar junto na construção da conversa, de se colocar junto. Se corresponsabilizando pelo rumo da conversa. Me veio um pouquinho essa ideia, faz sentido isso?

Lina: Sim. [...] Eu não sei se eu estou entendendo exatamente o que você está falando, eu... o corresponsável você está dizendo é não ir deixando a conversa tomar qualquer rumo.

Gabriela: Sim.

Lina: Tá. Isso eu me vejo totalmente. $\mathrm{E}$ acho que isso cada vez mais, estou ficando cada vez mais preocupada com isso. [..] tem me gerado bastante reflexão do que precisaria acontecer, de fato, para eu poder me responder: "os clientes conseguiram levar algo diferente do que trouxeram", né? Acho que essas coisas têm me convidado muito, sabe, onde é o limite do ser empático com fazer uma escuta e ter paciência com o outro, e onde realmente se ajuda o outro a produzir mudanças, diferentemente do que se ele estive em qualquer outro contexto. Porque empatia ele pode conseguir em outros lugares.

No momento da sessão, quando Lina explicita o processo comunicacional em andamento e as posições que cada pessoa está assumindo naquela conversa, ela faz um convite à corresponsabilização pelo que acontece na terapia. Lina (atuando na dimensão do processo da conversa) responsabiliza-se pela coordenação da conversa enquanto inclui a dimensão do conteúdo que está sendo dito, explicitando a função que as falas de Vivian assumem nas relações das terapeutas com Vivian e Igor, e entre o casal. Assim fazendo, convida Vivian a assumir parte da responsabilidade sobre os rumos da sessão e a escalada dos conflitos entre o casal, enquanto indiretamente toca na responsabilização de Igor pelo processo, pois torna implícito que não lhe dará a chance de trazer sua versão dos fatos em outro "monólogo", como Vivian fez até o momento. Ao questionar a utilidade das terapeutas nesta conversa - em que nos tornamos expectadoras, ouvintes da perspectiva de Vivian - Lina também nos corresponsabiliza pelo processo terapêutico e os efeitos que esta conversa vai criando na relação entre o casal e entre nós duas e eles. Assim, inicia-se um momento de conversa entre as terapeutas - em que o casal é posicionado como ouvinte - no qual discutimos possíveis caminhos para a continuidade da conversa. A não inclusão do casal nesta conversa evidencia, ainda mais, a responsabilidade e diretividade que as terapeutas assumem neste papel de coordenação da conversa. 
Este trecho de sessão ilustra o complexo interjogo de responsabilidade no contexto terapêutico. Por um lado, há a corresponsabilidade pela construção da relação terapêutica. McNamee e K. Gergen (1999) utilizam o termo responsabilidade relacional para evidenciar que o que tomamos como sendo a ação autônoma de uma pessoa é, de fato, uma ação em relação às pessoas presentes e às vozes presentificadas que cada um de nós carrega. Assim, a responsabilidade não pode ser localizada em um único indivíduo, uma vez que toda ação ocorre no seio de uma relação e inclui as pessoas presentes e presentificadas naquele momento. Quando Vivian fala conosco naquele momento, todos nós (Gabriela, Lina e Igor) estamos incluídos no que é dito. Esta forma de compreender a situação implica que não era Vivian falando por si mesma, mas sim agindo na relação que mantém com todos nós. Sensível à como estas falas de Vivian posicionam cada um, Lina intervém e, juntas, as terapeutas reorganizam os caminhos pelos quais a conversa estava seguindo.

Por outro lado, há a responsabilidade da terapeuta na coordenação da conversa e a preocupação em construir um contexto que seja minimamente diferente de contextos de violência em que este casal vive, como afirma Lina na interlocução. Neste sentido, a terapeuta vê-se "interventiva" e "recortando bem os espaços de fala", proporcionando um espaço em que aquilo que se fala e o como será dito seja diferente do que estão acostumados em seu dia-a-dia, sobretudo por envolver questões de violência.

Vemos, assim, que a coordenação da conversa é algo que ocorre no delicado espaço onde as responsabilidades se entrecruzam e a terapeuta precisa encontrar caminhos que, ao mesmo tempo que seguem uma orientação ética e proporciona uma conversa diferente das conversas cotidianas, também inclui os clientes e suas possibilidades dentro daquilo que eles dão conta de construir como diálogos diante de emoções e vivências conturbadas. Há, sobretudo, a necessidade da terapeuta não permitir que o setting terapêutico seja outro contexto para a reprodução de violência entre o casal.

\section{b. Temática: Metacomunicar}

Entendemos a metacomunicação como a ação de comunicar sobre a comunicação (Watzlawick, Beavin \& Jackson, 1973/2007), cujo tema pode ser a 
própria conversa ou, também, o que a conversa está provocando nas pessoas em determinado momento da sessão.

Terapeuta Lina, Casal Motta, Sessão 1

Estávamos conversando com Igor acerca da história do casal, e ele havia comentado sobre suas dificuldades de falar sobre esses assuntos, muitos dos quais ele não está habituado a conversar com ninguém.

Lina: E Igor, quando você fala: "eu não costumo falar", te incomoda a gente ficar perguntando dessas coisas? Porque aqui a gente vai perguntar [rindo].

Igor: Não, porque para mim é mais fácil vocês perguntarem do que eu me... me dispor. Gabriela: Espontaneamente falar dessas coisas.

Igor: Exato. É mais fácil vocês questionarem e eu ir respondendo. Aí eu vou respondendo conforme vocês forem perguntando, e conforme vai abrindo leques para... para achar ou tentar que esse emocional saia, aí fica com vocês.

Lina: Unhun. Unhun. Se em algum momento a gente fizer alguma pergunta e que você não quiser tratar, você avisa a gente, tá?

Terapeuta Anna, Casal Luis e Ligia, Sessão 4

Estávamos na metade da sessão, e explorávamos a ideia que o casal tem sobre o que é "conversar".

Anna: Eu fico ainda pensando na questão do que é o conversar, como você tinha trazido [falando com Gabriela], qual é a ideia que eles têm. E agora estou pensando: já que o sinalzinho do outro não vem, de começar a falar, eu fico pensando o quanto eu, se eu tenho vontade de falar alguma coisa, o que eu posso falar, o que eu posso contar para o outro de mim, do que eu estou pensando. Fico pensando. Aqui [na terapia], assim, a gente está conversando. Vocês estão dizendo que percebem ou sentem que aqui a gente está conversando, é isso?

Luis: Correto.

Anna: O que que acontece aqui que está possibilitando essa conversa acontecer?

Luis: Não é que esse local está nos forçando a falar, mas a gente já sabe que essa uma hora é para a gente conversar.

Anna: Então...

Luis: Acho que nós, nós evoluímos bastante nessas quatro sessões, não é Ligia?

Ligia: É, a gente falou sobre nós, mas eu queria que isso... é que as dez sessões vão terminar e nossa vida não. [...]

Anna: Então, mas essa uma hora aqui está acontecendo, vocês estão falando. Uma coisa é falar: "então na terça-feira tem a sessão de terapia e nós vamos conversar". Parece que tem um acordo, um combinado, é isso?

Nestes trechos, Lina e Anna tomam a comunicação na terapia como tema de conversa. Igor apresenta uma dificuldade inicial para responder perguntas sobre a história do casal e explicita que este é um tema difícil para ele. Diante da 
metacomunicação do cliente, Lina segue este caminho e aborda as perguntas que estão sendo feitas pelas terapeutas, buscando estabelecer uma relação em que ele possa sentir-se à vontade para falar caso sinta-se desconfortável com alguma pergunta realizada.

No trecho de Anna, a terapeuta novamente aborda uma dificuldade do casal articulando-a com as vivências na relação terapêutica. Diante de seus problemas em iniciar e manter uma conversa em andamento, Anna traz o foco para a conversa terapêutica e a forma como esta não apenas se inicia tranquilamente todas as sessões, como também se mantém acontecendo por uma hora. Busca iluminar, com eles, os elementos de contexto que tornam possível que isso aconteça. Conversando sobre a conversa terapêutica, Anna indiretamente faz uma metacomunicação sobre a conversa do casal, buscando descrever os recursos que eles podem incluir em suas conversas para que elas se iniciem e tenham andamento.

Terapeuta Anna, Casal Luis e Ligia, Sessão 8

Estávamos no final da sessão, e Anna delineava o desfecho de sua conversa com Ligia, que ocorrera enquanto Luis e eu ficávamos na posição de escuta. No início do encontro, Ligia havia comentado que estava muito nervosa com a entrevista que iria ocorrer - tão nervosa que ela estava com frio na barriga e suas mãos estavam geladas.

Ligia: Meu problema está aqui [apontando a cabeça].

Anna: Mas o problema está sendo conversado, está sendo olhado, está sendo falado. Vocês se propuseram, você está aqui olha, você falou comigo. Como é que está sua mão agora? [Anna toca na mão de Ligia].

Ligia: [risos]

Anna: Está quentinha.

Ligia: Melhorou.

Anna: Como é que está sendo a conversa aqui comigo, sobre essa tema, que você falou que é um tema que dá frio na barriga?

Ligia: Ai, não sei. Não lembro de ter falado essas coisas para o Luis, algum dia ter falado desse jeito. Eu nem sei se ele sabe que eu penso desse jeito.

Anna: $E$ conversar aqui comigo. $O$ que te ajudou essa conversa acontecer comigo, o que eu fui fazendo?

Ligia: Olha, eu vou dizer uma coisa, no começo tinha um nó aqui [mostra a garganta]. Foi difícil, assim, falar.

Anna: Uhun. Eu imagino, Ligia. Eu imagino.

Ligia: Mesmo porque tem duas pessoas ouvindo, né? E são coisas que a gente não fala, né? Eu acho difícil falar.

Anna: E como foi, no começo estava um nó, o que é que foi acontecendo com esse nó?

Ligia: Não, eu acho que foi uma condução, assim, da conversa. Talvez tenha muito mais coisa para falar, mas eu consegui falar algumas coisas que na minha cabeça estava processando, acontecendo.

Anna: E o nó?

Ligia: O nó... 
Anna: Está aí, o nó?

Ligia: Só um pouquinho [risos].

Anna: Diminuiu de tamanho. O que você acha que aconteceu, o que eu fiz, como a gente conversou que ajudou o nó a diminuir de tamanho?

Neste trecho, a metacomunicação aborda simultaneamente dois níveis da conversa: a conversa em si e como ela foi se processando, e como Ligia foi se sentindo durante a conversa sobre temas tão difíceis e delicados para ela. Entremeando perguntas que exploram estes dois níveis, Anna pode, a um só tempo, ter um feedback sobre como Ligia foi manejando o nervosismo inicial e também criar um tópico de conversa em que todos podem compreender aspectos que a ajudam a ter conversas difíceis. Isto é relevante tanto para as terapeutas à medida em que nos orienta em conversas futuras, mas sobretudo para o casal, que vai conhecendo outros recursos que podem acompanha-los na criação e manutenção das conversas que eles desejam.

Sobre o uso da metacomunicação como um recurso nestes atendimentos, as terapeutas comentam:

Gabriela: Você falou então que você começa a pensar em posicionamento, a gente está falando de teoria do posicionamento, é isso?

Lina: Isso.

Gabriela: Quando você falou dessa ideia do posicionamento. O que mais você falou, quando você fala de parar pra olhar o que a gente está fazendo aqui, essas conversas, com quem que você vai conversando, teoricamente, que te leva pra esses...

Lina: Ai, agora, o que me vem na cabeça é a teoria do posicionamento mesmo e, talvez, a questão de... de distinção do processo, aí talvez, olhar de novo o que a gente está fazendo junto, ali. Que aí também [pausa] alguma coisa não do posicionamento, agora eu estou conversando um pouco com o Karl Tomm, né? O olhar para conversa que está acontecendo. E até alguma coisa no sentido assim: "o que eu ainda não te perguntei que te ajudaria? $O$ que você gostaria que eu te perguntasse? Que caminho você está esperando que a gente tome?" Porque tem alguns momentos em que parece que... [...] várias das vezes com a Vivi, várias vezes eu fiquei né, ao ler, eu falei: "nossa eu... eu pararia de falar do assunto e eu iria falar do que a gente está fazendo aqui", né? Isso tanto nas vezes que eles começam a brigar entre eles e se alfinetar, quanto nas vezes em que a gente vai oferecendo coisa e nada vai servindo... ou assim né, tudo ela já fez, ela já tentou. Eu acho que hoje eu faria diferente, eu iria pra questão do posicionamento em que cada 
um vai se colocando, colocando o outro, inclusive nós. Não sei porque na época a gente não fez.

Anna: [...] Então, é uma dança e é uma dança sem tempo pra ensaiar antes. É uma performance mesmo, a gente vai performando mesmo, com o outro, com os outros.

Gabriela : E é uma atenção a esses pequenos sinais também, né? É muita atenção.

Anna: É, é muita coisa ao mesmo tempo.

Gabriela: É, é muita coisa. Exatamente isso que eu estou pensando.

Anna: E vai muito da hora ali, do momento, do sentido.

Para Watzlawick, Beavin \& Jackson (2007), toda comunicação possui dois níveis: o conteúdo do que é dito e a definição da relação. A definição da relação é um elemento implícito e envolve mais do que o conteúdo, pois determina como este deverá ser interpretado - inclui a forma como as palavras são proferidas, o momento em que são ditas, o contexto, as pessoas a quem se dirigem e outros elementos. A metacomunicação pode tomar estes níveis da conversa como objeto de atenção, o que dá a oportunidade de esclarecer não apenas questões sobre o conteúdo, mas sobre os aspectos da relação que está se estabelecendo entre os presentes, no momento a momento da sessão.

Tomm (1988) considera que a metacomunicação é importante para promover a colaboração na conversa terapêutica. Segundo o autor, o trabalho do terapeuta envolve o que ele denomina como metaperguntas, que versam sobre o conteúdo da conversa e a forma como está se desenvolvendo a mesma. Para ele, em geral, o terapeuta faz este tipo de pergunta para si mesmo sem trazê-las para os clientes. Sua proposta é que estas perguntas sejam feitas também na conversa, permitindo aos clientes avaliarem e ajudarem a definir rumos. Lina afirma agir influenciada por estas ideias em suas ações de metacomunicação, permitindo uma forma de participação diferente do cliente no processo conversacional - por exemplo, para além de responder perguntas, o cliente pode também comunicar a respeito de como está se sentindo com as mesmas e influenciar imediatamente na direção do diálogo. Este tipo de conversa abre espaço para que posicionamentos sejam negociados.

A teoria do posicionamento apresenta uma compreensão discursiva da construção da pessoalidade sob uma perspectiva relacional, dinâmica e que envolve a 
dimensão social dos fenômenos psicológicos (Davies \& Harré, 1990). Na concepção dos autores, a posição refere-se aos lugares sociais assumidos e negociados pelas pessoas em diálogo. Assim, nas interações sociais há um constante interjogo de posicionamentos entre os interlocutores (presentes e presentificados), que define as identidades de cada um. No que se refere às ações de metacomunicação aqui analisadas, os trechos ilustram momentos em que as posições de cada interlocutor da sessão podiam ser negociadas a partir do conversar sobre a conversa: no primeiro trecho, Igor vai da posição de alguém que deve responder perguntas para alguém que pode manifestar-se caso esteja desconfortável com as perguntas realizadas; no segundo trecho, Luis e Ligia, antes na posição de um casal que não consegue manter uma conversa em andamento, são posicionados por Anna como duas pessoas que possuem recursos para manter uma conversa ao longo de mais de uma hora de sessão, semanalmente; no terceiro trecho, Ligia passa a ocupar a posição de alguém que pode sentir-se confortável mesmo quando conversa sobre tópicos difíceis, e também é posicionada como uma pessoa que pode identificar o que lhe faz sentir-se bem para ter estas conversas - consequentemente, Luis é posicionado como alguém que, agora, poderá lançar mão de novos recursos para conversar com a esposa.

Como afirma Anna, ações de metacomunicação envolvem uma ampliação da atenção das terapeutas, que expandem os níveis comunicacionais com os quais estão trabalhando, no desenrolar de performances que visam, prioritariamente, produzir mudanças em cada um dos envolvidos.

\section{c. Temática: Utilizar a co-terapia como recurso para a comunicação}

Em todas as sessões, com ambas as terapeutas, a co-terapia foi utilizada como um recurso para a construção do contexto conversacional (nesse sentido, essa temática não deixa de envolver uma dimensão metacomunicacional). $O$ engajamento de duas terapeutas no processo terapêutico proporcionou a criação de contextos próprios, e diferentes usos foram feitos deste recurso. Abaixo, descrevemos estes usos com base no que aconteceu nos atendimentos e dispensamos a apresentação de trechos de sessões, uma vez que estes podem ser reconhecidos nos exemplos das temáticas anteriores. 
Explorar diferentes pontos de vista: Em alguns momentos, a terapeuta que estava conduzindo a conversa consultava a co-terapeuta com o interesse de saber o que ela estava pensando sobre o assunto em curso, ou sobre como estava se desenrolando a conversa entre a terapeuta e os clientes.

\begin{abstract}
Definir, em conjunto com a co-terapeuta e os clientes, qual seria o caminho da conversa: Em uma conversa apenas entre as terapeutas, explorávamos alguns rumos pelos quais a conversa terapêutica poderia seguir. Após definir possibilidades, negociávamos com os clientes qual seria o tema para a continuidade da conversa. No uso deste recurso, uma mudança em nossa postura corporal marcava a alteração nas posições de fala e escuta, e ao conversamos entre nós duas diferenças poderiam ocorrer: (a) cada terapeuta movia seu corpo e ficávamos frente à frente, com os olhares voltados apenas uma para a outra (sem olhar para os clientes); ou (b) cada terapeuta movia sua cadeira, delineando mais marcadamente um espaço conversacional próprio e, novamente, conversávamos olhando apenas uma para a outra.
\end{abstract}

Definir, apenas entre co-terapeutas, qual seria o caminho da conversa: Por vezes, as terapeutas conversavam entre si elencando possíveis temas para continuidade da conversa e escolhendo em qual deles seguiríamos as explorações com os clientes.

Dar visibilidade ao que está compreendendo sobre a conversa: a terapeuta que estava conduzindo a conversa voltava-se para a co-terapeuta fazendo um resumo daquilo que ouvira dos clientes, dando ênfase a alguns aspectos que ela considerava mais marcante e, às vezes, fazendo articulações com coisas que os clientes já haviam dito anteriormente (na mesma sessão ou em sessões anteriores).

Criar uma "pausa" na interação em curso: sobretudo em momentos tensos de algumas sessões, iniciávamos uma conversa entre terapeutas como um recurso para organizar nossas percepções e entendimentos acerca do que acontecia na sessão, dando-nos a possibilidade de pensar em rumos e perguntas para os clientes, sem a "pressão" de estar em conversa com eles enquanto fazíamos estas reflexões e tomávamos tais decisões.

Conduzir "entrevistas" com um cônjuge, enquanto o outro permanecia na posição de escuta: este recurso foi inspirado na equipe reflexiva proposta por Andersen (2002), e utilizado com o objetivo de ampliar perspectivas e potencializar a busca por soluções (Fiorini, Guisso \& Crepaldi, 2017). Consistiu em uma forma específica de alterar posições de fala e escuta que ocorreu em duas sessões. A partir do andamento do processo terapêutico com Luis e Ligia, as terapeutas perceberam que poderia ser útil fazer uma conversa com apenas um cônjuge, enquanto o outro cônjuge e a co-terapeuta ficavam na posição de escuta. A partir de um combinado prévio com todos os participantes, cada cônjuge foi entrevistado ao longo de uma sessão. Nos quinze minutos finais do encontro, as posições de fala e escuta alternavam-se: a coterapeuta conduzia uma conversa com o outro cônjuge, acerca de como havia sido escutar a entrevista e quais reflexões poderiam ser compartilhadas. 
O uso da co-terapia era uma condição criada para a realização da pesquisa, mas acabou se constituindo como um recurso para a construção do contexto conversacional, tendo assim alguns objetivos na parceria realizada com as terapeutas. Em alguns momentos, atendia às necessidades das terapeutas, estando mais próximo de uma maneira de coordenar a conversa e definir formas pelas quais a conversa poderia prosseguir, segundo nossos critérios do que seria um bom caminho. Em outros momentos, o uso parecia atender a necessidades do sistema terapêutico como um todo, agora incluindo tanto terapeutas como clientes, como um recurso que nos permitia ampliar as informações disponíveis, enriquecer pontos de vista e narrativas, trazer aspectos inusitados e com mais potencial generativo. A co-terapia parecia enriquecer a criatividade e a potência do encontro terapêutico. Tal uso parece conectar-se com o que Andersen (2002) define como sendo o pressuposto da equipe reflexiva: criar formatos específicos de conversas que alternam posições de fala e escuta, possibilitando que os interlocutores se façam novas perguntas e, consequentemente, criem novas formas de encarar seus problemas. Mesmo que não tenhamos criado um contexto de atendimento baseado estritamente na ideia da equipe reflexiva, os diferentes formatos em que alternamos fala e escuta consistiram em um uso criativo e situado da proposta do autor.

\subsubsection{Categoria: Ações de orientação familiar}

Esta categoria inclui ações que intervêm mais diretamente sobre o problema apresentado pela família e surgem quando as terapeutas agem a partir de um lugar de especialista, no sentido em que a conversa embasa-se em conhecimentos prévios da terapeuta.

\begin{tabular}{lll}
\hline \multicolumn{1}{c}{ Categoria } & Temáticas & Terapeuta \\
\hline $\begin{array}{l}\text { Ações de } \\
\text { orientação } \\
\text { familiar }\end{array}$ & Oferecer informações & Anna \\
& Dar tarefas & Lina \\
\hline
\end{tabular}

Quadro 8. Temáticas que compõem a categoria "Ações de orientação familiar” 


\section{a. Temática: Oferecer informações}

Essas ações abarcam momentos em que a terapeuta dá orientações específicas aos clientes acerca de algum assunto, lançando mão de um corpo de conhecimentos científicos que embasam seu posicionamento.

Terapeuta Anna, Casal Luis e Ligia, Sessão 5

Ligia contava à Anna sobre algumas dificuldades que sente em relação à sexualidade e dúvidas que tem sobre o climatério. Então, faz um pedido:

Ligia: [...] Eu não sei se tem alguma coisa na literatura que ajuda, uma indicação de leitura...

Anna: Pois é. Eu fiquei pensando nisso também, Ligia. Eu queria até conhecer um pouquinho o que você já leu, por onde você já percorreu nesse assunto.

[Anna e Ligia exploram o que ela já leu, que são informações provenientes, sobretudo, de revistas voltadas para a área da saúde e acerca do climatério]

Anna: Essa que é uma questão, né? Né, Gabriela?

Gabriela: Sim.

Anna: Da gente, antes de ficar pensando, talvez a gente precise olhar um pouco para o que é o sentimento da mulher, do que pensar nas transformações. Que transformação é essa se a gente não conhece nem o básico? Para a gente saber o que é que está transformando. Só para você ter uma ideia, tem mulheres que, nessa fase do climatério por exemplo, o fato de estarem chegando na maturidade da vida, de já estar despreocupada em relação a se engravida ou não engravida, e de já se conhecer e já estar realizada profissionalmente, às vezes transforma no sentido de estar mais ativa sexualmente, no sentido de estar mais realizada pessoalmente, consigo mesma. Então, a gente precisa ter cuidado com essas literaturas que vão mostrando só um único caminho para a gente, como mulher. Porque existem também outros relatos de mulheres que nesse momento é que se descobre, nesse momento é que passa a ter mais prazer que antes não conhecia ter. Tem um outro tipo de possibilidade também para isso. Mas eu ainda fico pensando o quanto, pela forma como você foi criada ou o tipo de informação que você foi tendo, logo desde jovem, o que é sexualidade, onde a gente tem prazer... às vezes tem alguns mitos que, ao invés de ajudarem a gente, atrapalha [...] Então eu trago o livro na semana que vem, te empresto. Pode ser até uma leitura, assim, nova, gostosa de se fazer, entendeu? Uma coisa extra, agora, para vocês. $E$ não é só para a Ligia não, viu Luis? [risos] O Luis também precisa conhecer como a mulher funciona, né? Ajudar a companheira a também ter esses momentos de... enfim, conhecer.

À medida que conversamos com Ligia, percebemos que suas informações acerca do climatério são provenientes de fontes que possuem o que entendemos ser um 
menor rigor científico para lidar com questões de saúde e trazem, muitas vezes, um apelo midiático que distorce aspectos importantes das vivências femininas. Assim, Anna intervém no sentido de oferecer informações cientificamente embasadas, oferecendo ao casal um livro que aborda estas questões e descrevendo-o como uma "coisa extra" que pode oferece-los um novo repertório para entender as vivências femininas na fase da vida em que Ligia se encontra.

$\mathrm{Na}$ interlocução com Anna, produzimos sentidos sobre estas ações:

Anna: Me ajuda a ficar mais confortável de ver que tem momentos de acolhimento, momentos de exploração, momentos de intervenção sobre o problema, né? Então, assim, que não foi um encontro só daquele tipo que talvez seja o pavor da gente, né? Falo pelo menos por mim. De ser aquela terapeuta diretiva, que desrespeita. Por outro lado, também não dá para ficar só acolhendo, né? Ou só explorando. [...] $\mathrm{O}$ cliente não vem para nós sem um pedido. Pelo menos que eu saiba. $\mathrm{E}$ eles [Luis e Ligia] tinham isso muito claro. Então, olha, tem essas várias ações [apontando o material], não tem só um tipo de ação. $\mathrm{O}$ que me conforta muito. Agora, não tem como não ter intervenção. Se existe um pedido, quer queira, quer não, nós estamos no lugar de um profissional que a pessoa procura com um objetivo claro de olhar para uma determinada coisa, que chama de problema ou de dificuldade, o que for. Mas tem um pedido. E a gente parte, inclusive, no início das sessões, com isso: o que espera da terapia, o que veio buscar.

A ação de Anna possui algumas dimensões que valem ser destacadas. Constituise em uma orientação voltada para um conteúdo específico, na medida em que esclarecerá o casal sobre sexualidade e climatério. Ao mesmo tempo, é uma orientação voltada para a interação entre o casal, pois Anna não apenas indica o livro, mas também diz quem deverá lê-lo - não só Ligia, mas Luis deve conhecer mais sobre o assunto para, possivelmente, trazer novos repertórios para a relação do casal. Por fim, é uma ação que orienta em termos da visão socialmente difundida acerca do climatério como declínio e perda da satisfação no âmbito da sexualidade. $\mathrm{O}$ trecho da interlocução indica que Anna fica entre o "pavor" de ser diretiva e a necessidade de atender os pedidos do casal. Ao oferecer uma direção clara na conversa (o que poderia parecer como uma ação desrespeitosa e diretiva), Anna vai além da exploração e do acolhimento, trabalhando diretamente alguns "pontos nevrálgicos" das questões do casal de modo mais interventivo. 
A nosso ver, o contexto conversacional que gera a ação de orientar os clientes transforma-a em uma forma responsiva de se relacionar com o casal e, sobretudo, com Ligia. Anna agiu como uma "especialista relacional" (Doricci, Crovador \& Martins, 2017), na medida em que o uso de conhecimentos especializados torna-se um convite para a produção de novas descrições, que ampliam as ideias e o repertório dos clientes. Além de favorecer a continuidade do diálogo, como frisam os autores, a postura de especialista relacional assumida por Anna também gera acolhimento e legitimação dos distintos saberes: tanto os saberes especializados da terapeuta quanto os conhecimentos leigos de Ligia, os quais são posicionados como fruto de sua história. Ao indicar os limites dos saberes de Ligia, Anna oferece possibilidades de vida mais libertadoras.

\section{b. Temática: Dar tarefas}

Esta temática refere-se a momentos em que a terapeuta indica ou explora, de forma direta, ações que devem ser realizadas por cada pessoa.

Terapeuta Lina, Família Silva, Sessão 3

Estávamos no final da sessão, e Lina já havia comentado acerca de um autor que escreve sobre questões que têm muito a ver com o que falamos durante a sessão. Ao final do encontro, Lina retoma esta indicação de leitura.

Lina: Amanda, você tem e-mail?

Amanda: tenho.

Lina: Posso te mandar então o "textozinho", e você fica com esta incumbência, se você gostar do que você leu, de passar para sua mãe e para o seu pai?

Amanda: Passo.

Lina: Você pode convidá-los para um café [risos], e aí contar.

[risos de Renata e Amanda]

Neste trecho, a fala de Lina oferece uma diretiva para que Amanda leia o texto e, caso goste da leitura, encaminhe-o para os pais. Esta ação parece ter diferentes dimensões, para além de sua diretividade: de alguma maneira, aproxima Lina e Amanda ao dialogar com um "mundo" mais contemporâneo, ao enviar um e-mail 
com o texto em formato digital9; além disso, é uma ação voltada para a queixa da família de que não conseguem conversar entre si de forma tranquila e "civilizada" (sic), pois implica na construção de uma forma de comunicação alternativa (e-mail) e, simultaneamente, provoca a filha para unir-se ao "mundo" dos pais em um encontro face a face (e não virtual) para conversarem sobre o texto. É uma diretiva provocativa também porque convida toda a família para sair das formas habituais de se relacionarem para estarem juntos de forma diferente, mesclando seus mundos, em torno de um interesse comum - melhorar a convivência. E, se nesta nova experiência eles não conseguirem expandir seus tópicos de conversa espontaneamente, o texto em si já é um novo assunto sobre o qual podem conversar.

As ação de dar tarefas parece estar inspirada nas diretivas terapêuticas propostas por Haley (1976). O autor as define como um conjunto de instruções que a família deve seguir dentro e fora do consultório, com os objetivos de: otimizar o tempo; permitir o controle do terapeuta sobre a família, uma vez que ele torna-se presente mesmo estando ausente; e permitir uma generalização do contexto terapêutico para o mundo exterior (Haley, 1976).

As ações de Lina com a família Silva atendem estas dimensões discutidas pelo autor: primeiro, consistem em instruções que a família deve seguir (no caso, apenas fora do consultório), com papéis definidos para cada subgrupo da família; segundo, otimizam o tempo porque são ações a serem realizadas fora do atendimento e que destinam-se a agir sobre os problemas da família; terceiro, permitem que Lina tornese presente na vida da família mesmo estando ausente - acessar o e-mail, ler, indicar a leitura para os pais que, por sua vez, também leriam o material, saírem juntos para conversar sobre a leitura - todas estas são ações que surgiriam em função da diretiva de Lina, cuja presença "invisível” os acompanharia em cada ação; por fim, podem permitir que as conversas do âmbito da terapia sejam generalizadas para contextos externos à ela, na medida em que a leitura indicada aborda os problemas da família e podem oferecer ampliações para lidarem com suas dificuldades.

Contudo, é importante apontar uma diferença relevante das ações de Lina em relação à proposta de Haley (1976) - não há obrigatoriedade nem cobrança em relação ao cumprimento da diretiva, como era usual nas intervenções do autor. Diferentemente, a leitura é vista como um recurso para criar conversas com potencial

9 Neste particular, é importante ressaltar que a principal queixa de Amanda era a dificuldade dos pais compreenderem e aceitarem questões, escolhas e ideias relacionadas ao "seu mundo", que ela descrevia em termos de um mundo contemporâneo. 
transformador, a partir da ampliação de linguagens e metáforas pelas quais os problemas podem ser descritos e, consequentemente, enfrentados.

Terapeuta Lina, Casal Motta, Sessão 7

Estávamos em um momento bastante tenso da sessão, em que o casal falava em tom de hostilidade, raiva e inconformidade, conversando ora conosco e ora entre eles, cada qual trazendo seu ponto de vista sobre as brigas que levaram a um episódio de violência física durante a semana. As interações tensas na sessão já aconteciam há algum tempo. Neste momento, Lina interrompia as falas do casal - Igor parou de falar, mas Vivian não parava, chorando com os dentes cerrados, repetindo sua visão sobre o conflito em pauta. Lina a interrompe de modo mais incisivo e, em tom sério, dá seguimento à conversa, buscando .

Lina: A gente costuma ir fazendo um trabalho muito no sentido de ir vendo o que um precisa e o que o outro precisa. Nesse momento eu não tenho vontade de ver o que vocês precisam, eu tenho vontade de dizer o que, pelo menos eu como profissional, preciso para vê-los minimamente protegidos de vocês mesmos. E não é um do outro, é de vocês mesmos. E uma coisa eu tenho certeza - não é argumentando que vocês vão conseguir isso. [breve pausa] $O$ nosso tempo de sessão já deu. Eu não vejo como algo possível vocês ficarem coabitando o mesmo teto neste jeito que vocês funcionam. Não vejo. Isso não diz respeito a dizer que um está certo e outro está errado. Isto se refere que vocês dois conhecem muito bem como ir rapidamente naquilo que faz o outro estourar. Vocês já viveram isso outras vezes, não é bom para ninguém. [...] Na casa de vocês, ahn... quando vocês estão assim, vocês dormem no mesmo quarto? Tem como pedir para ele mudar de quarto?

Vivian: Eu peço para ele dormir na sala, mas ele não dorme.

Lina: Como que é, tem quarto dos filhos?

Vivian: Ou às vezes eu vou, eu vou. Só que chega no meio da madrugada e ele me cutuca: "deixa eu dormir aqui".

Lina: $\mathrm{E}$ aí você vai.

Vivian: E daí 5 minutos ele está na cama de volta, entendeu?

Lina: Tem como irem para o quarto dos filhos?

Vivian: Eles não vão sair [em tom taxativo].

Lina: Sair de onde?

Vivian: Dos quartos.

Lina: Mas não dá para vocês ficarem juntos, mais um?

Vivian: Não, não tem... espaço físico. E eles não vão sair. Eles não vão colaborar.

Lina: Por quê? Eles querem ver a coisa ficar bem ruim, Vivi?

Vivian: Não, eles falam assim para mim: "você não quis voltar com ele? Agora o problema é seu”. Entendeu? Ou: “eu não vou me intrometer". A Luísa fala assim para mim: "no meu quarto você não vai dormir". E o Leonardo fala desse jeito: "problema é seu, você que deixou ele voltar". Eles não colaboram.

Lina: Igor, você, da sua parte, o que você pode fazer nessa semana para não deixar a coisa galgar? Você escutou aqui a Vivi falando algumas coisas que ela vê como possibilidade, mas aí ela acha que não vai adiantar porque ela acha que vai acontecer alguma outra coisa. Por exemplo, como a questão de ir para o sofá. Alguma dessas coisas você vê como possível?

Igor: O sofá.

Lina: O sofá para quem?

Igor: Para mim, ela tranca a porta do quarto. Ah, para! 
[Vivian suspira]

Vivian: Eu tranco a porta do quarto porque ele vai para lá, gente!

Igor: Eu vou dormir no sofá. Pronto, morreu. Acabou.

Vivian: Eu até...

Igor: Não, encerrou. [Igor e Vivian começam a falar ao mesmo tempo]

Lina: Espera um pouquinho. O que você está dizendo é que você vai para o sofá.

Igor: Eu vou.

Lina: Tem colchão extra na casa de vocês?

Igor: Não, porque foi feito tudo sob medida.

Gabriela: E em termos da rotina diária, seria possível vocês tentarem ficar juntos em casa o menor tempo possível?

Vivian: A gente só fica em casa à noite. Não tem como não ficar.

Igor: De dia não fica.

Vivian: E é um banheiro só, então à noite não tem jeito, tem que dividir, não tem jeito.

[...]

Lina: Então, Igor, você está se comprometendo a você dormir na sala?

Igor: Eu vou dormir na sala, eu não entro no banheiro enquanto ela estiver lá, na boa. [...]

Lina: Unhun. Ok. Tem alguma coisa que dificultaria isso para você, Igor?

Igor: Tomar essas atitudes? Não.

Lina: Tá. Então isso é uma coisa que você conhece que dá conta, independente do que possa acontecer.

Igor: Sim.

[Em uma conversa que ocorre de forma semelhante à essa, por parte das terapeutas, vão sendo feitos outros combinados para esta semana: em quais momentos será estritamente necessário conversarem entre si, como vão se organizar no final de semana, entre outros.]

Este trecho ilustra o uso de uma maneira diretiva e incisiva de estar em relação com os clientes no contexto específico que são os casos de violência na família. Lina faz, claramente, um corte no conteúdo e na forma como estava conduzindo a sessão até o momento, passando para um foco dirigido à construção de acordos que possam oferecer algumas condições de segurança para o casal, em um tom sério e propositivo.

No início do trecho, quando Lina descreve aos clientes o motivo pelo qual vai mudar o direcionamento da conversa, ela posiciona tanto suas necessidades como as dos clientes como força motriz de suas ações. As diretivas não estão voltadas para alguma ação específica, como no trecho da Família Silva, mas referem-se à construção conjunta dos elementos que irão compor um combinado entre os cônjuges e entre ambos e as terapeutas. A nosso ver, a ação de Lina: inclui os limites e possibilidades de cada cônjuge (pois podem dizer o que dão ou não conta de fazer), convida a um maior comprometimento (porque o casal é co-autor do combinado), e convida à corresponsabilidade (por não serem condições impostas, o casal está 
implicado na construção que é feita e, consequentemente, no cumprimento ou não de cada elemento do combinado). Cada elemento deste combinado parece compor parte de um andaime (White, 2012) que Lina vai construindo com o casal, ajudando-os a construir recursos para evitar novos episódios de violência.

Finalizamos, assim, a apresentação e discussão das categorias de análise. A seguir, discutimos as maneiras pelas quais o uso destes recursos e conhecimentos constituem uma forma de integração na prática clínica de Lina e Anna.

\subsubsection{Construindo sentidos sobre a integração na prática clínica}

O quadro a seguir apresenta uma síntese das informações abordadas neste capítulo. A primeira coluna da esquerda apresenta as categorias de análise. $\mathrm{Na}$ segunda coluna, descrevemos a definição de cada categoria. Na terceira coluna, encontram-se as temáticas de cada categoria e, na quarta coluna, apresentamos a definição de cada temática. Na última coluna, apontamos os aportes teóricos e práticos que utilizamos para discutir o uso dos referidos recursos - tanto as inspirações narradas pelas participantes, quanto aquelas que discutimos a partir da análise do material. 


\section{Categorias}

Ações exploratórias

Definição

Temáticas

Descrição

Inspiração

Constroem conhecimentos

que orientam a terapeuta e a

família. As perguntas

convidam os membros a

trazerem informações,

descrições e discursos sobre

eles mesmos ou outras

pessoas.
Fazer perguntas de (historia do casal,

ória do problema,

entimentos, desejos,

preferências, etc.)

Explorar o sentido considerando a expressão não-verbal

Investigar a rede social e familiar

Fazer comentários e perguntas apreciativas

Explorar sentimentos ou intenções que movem ações

Explorar a exceção do problema

Explorar recursos para a superação do problema

Explorar o genograma
Atender à necessidade da terapeuta conhecer a família e os problemas vividos; construir sentidos transformadores

Construir sentidos que integram as dimensões do que é dito e do que acompanha o proferimento

Explorar relações significativas que compõem a rede social e familiar

Destacar elementos de força, competência, empenho e outros aspectos que aproximam os clientes do que desejam ser

Explorar dimensões que estão além das ações concretamente observadas

Investigar vivências que se opõem às narrativas do problema

Focar em recursos (utilizados anteriormente ou não)

ligados à história das pessoas com seus problemas

Explorar padrões e contextos familiares por meio da
- Self dialógico (Gergen,

2008, 2009)

- Rede social (Sluzki, 1997)

- Postura colaborativa

(Anderson, 2016)

- Perguntas lineares (Tomm, 1988)

- Diferentes dimensões da

linguagem (Sluzki, 2016)

- Investigação apreciativa (Cooperrider, Whitney \& Stravos, 2003; Souza,

McNamee \& Santos, 2010)

- Conversas de construção de andaimes (White, 2012)

- Conversas que iluminam eventos extraordinários (White, 2012)

- Foco pragmático da terapia e foco nas potencialidades dos clientes (Rasera \& Japur, 2004)

- Genograma (McGoldrick, Gerson \& Petry, 2012) 
Ações de construção de visões relacionais
Terapeuta faz perguntas e comentários que ampliam sentidos sobre os problemas, as pessoas e as possibilidades de mudança. Busca tornar mais complexas e relacionais as descriç̃es sobre si e sobre o outro, iluminando novos caminhos nas dimensões do sentir e agir.
No uso do genograma explorar a posição do cliente em relação à própria história

construção do genograma

Explorar como o cliente se posiciona, se posicionou no passado ou é posicionado

pelas pessoas de sua família em relação a diferentes assuntos e vivências

Descrever ou explorar diferentes selves de uma

pessoa

Fazer pergunta de implicação

Explicitar a coparticipação das pessoas na manutenção do problema na busca por soluções

Fazer explorações epistêmicas

Explorar ou descrever o padrão comunicacional ou relacional único e permanente

Buscar a construção de conhecimentos sobre si e o outro, com enfoque transformador e generativo

Iluminar aspectos da coordenação entre as

pessoas, geralmente
- Genograma (McGoldrick, Gerson \& Petry, 2012)

Questionar a ideia de um self

\author{
- Personagens internos \\ (Lenzi, 2013) \\ - Self dialógico (Gergen, \\ 2008, 2009)
}

- Conversas de construção de andaimes (White, 2012)

- Foco na polivocalidade (Rasera \& Japur, 2004)

- Processos reflexivos

(Andersen, 2002)

- Perguntas circulares

(Tomm, 1988)

- Postura colaborativa (Anderson \& Gehart, 2006)

correlacionando as

- Construção social das realidades cotidianas

(McNamee, 2004)

- Exploração de padrões que dimensões do agir e do sentir conectam a família (Bateson,

Jackson, Haley \& Weakland, 1956; McGoldrick, Gerson \& Petry, 2012; Selvini-

Palazzoli, Boscolo, Cecchin \& Prata, 1986; Tomm, 1988; 
Construir sentidos para além da queixa

Ampliar sentidos para que os clientes comuniquem mais diretamente seus desejos e pedidos

Abordar questões sociais e culturais que entrecortam o problema

Fazer perguntas de futuro

Focar no que é desejado ou desejável para a família, a partir do que trazem como situações que geram conflito

Fazer perguntas reflexivas

Convidar o outro a pensar sobre si mesmo, sobre si mesmo na relação e/ou sobre relações

Propor novas visões sobre as pessoas e suas relações, sob um ponto de vista mais

complexo

Fazer comentários reflexivos
- Conversas de construção de andaimes (White, 2012)

- Desconstrução da queixa e construção do pedido (Vicente \& Pereira, 2001)

- Terapia social (CamargoBorges, 2010)

- Prática clínica como uma atividade política (Gergen \& Warhuus, 2009)

- Prática envolvida em desconstruir narrativas opressoras (Moscheta, 2014

- Trazer o social para o individual (Martins, McNamee \& GuanaesLorenzi, 2017)

- Prática terapêutica com foco no futuro (McNamee, 2004)

\section{Processos reflexivos} (Andersen, 2002)

- Perguntas reflexivas (Tomm, 1988)

- Processos reflexivos (Andersen, 2002) 
Temáticas

Fazer um reenquadramento

Ações de construção da comunicação em contexto

Ações de orientação familiar
Terapeuta intervêm sobre o problema da família a partir de um lugar de especialista, embasando a conversa em

alguns conhecimentos prévios

Terapeuta age de forma voltada à construção do contexto conversacional, e também pode trazer reflexões sobre os efeitos da comunicação desenvolvida em terapia

Metacomunicar

Coordenar a conversa

Utilizar a co-terapia como recurso para a comunicação

Oferecer informações

Dar tarefas
Descrição

Oferecer novas perspectivas sobre o que é dito, tornando as descrições relacionais reduzindo polarizações

Atuar no fluxo

comunicacional para tornar conversa distinta do que os

clientes habitualmente têm

em sua vida cotidiana

Comunicar sobre a comunicação, cujo tema pode ser a própria conversa ou o que a conversa provoca nas pessoas

Utilizar a co-terapia como recurso para a construção do contexto conversacional

Orientar os clientes acerca de algum assunto, lançando mão de conhecimentos científicos

Indicar ou explorar ações que devem ser realizadas por cada pessoa
Inspiração

- Reenquadramento

Minuchin, 1980)

- Conversas de construção de andaimes (White, 2012)

- Responsabilidade relacional (McNamee \& Gergen, 1999)

\section{- Comunicação humana}

(Watzlawick, Beavin \&

Jackson, 2007)

- Metaperguntas (Tomm, 1988)

- Teoria do posicionamento

(Davies \& Harré, 1990)

- Equipe reflexiva (Andersen, 2002)

- Terapeuta como especialista relacional (Doricci, Crovador \& Martins, 2017)

- Diretivas terapêuticas (Haley, 1976)

- Conversa de construção de andaimes (White, 2012)

Quadro 9. Síntese das informações discutidas na análise e discussão dos dados 
Como indica o quadro 9, as ações das terapeutas são inspiradas em múltiplos recursos, cuja análise nos permitiu construir sentidos sobre a integração de aportes teóricos e práticos. A discussão das categorias evidencia que a integração de recursos é algo complexo que se tece como possibilidade no momento interativo, e de maneira absolutamente singular. Organizamos tais sentidos em três dimensões que caracterizam a prática das participantes em termos da integração de recursos teóricos e técnicos:

a. Sensível ao contexto e às pessoas: as terapeutas agem a partir de um constante modelar e remodelar de suas ações a partir do que os clientes narram como sendo sua forma de compreender e experienciar as situações, com abertura para mudar direcionamentos conforme o que a relação apresenta. Assim, seus norteadores são a atenção às mudanças no contexto e nos participantes do processo (inclusive elas mesmas), delineando seu envolvimento na relação terapêutica. A integração de recursos teóricos e técnicos acompanha esse caráter relacional, uma vez que o uso de cada aporte esteve atrelado às particularidades dos elementos de contexto e dos clientes de cada processo terapêutico.

b. Engajada em produzir conhecimento com as pessoas: as terapeutas criam contextos relacionais em que os conhecimentos são construídos de forma que os clientes são genuinamente incluídos nesse processo, de forma respeitosa e colaborativa. Difere, portanto, de uma prática em que a terapeuta vê-se como um expert que produz conhecimentos sobre as pessoas e define, a partir de seus próprios conhecimentos, quais são os objetivos do processo terapêutico. Do mesmo modo, ao integrar aportes teóricos e técnicos, as terapeutas transformavam seus conhecimentos prévios em recursos para a construção de conversas transformadoras, incluindo os clientes em processos de negociação e co-construção. 
c. Autorreflexiva: as terapeutas tomam a si mesmas como objeto de sua atenção e reflexão, identificando suas contribuições para o diálogo e as implicações para a construção da relação terapêutica. Há, desse modo, uma abertura para transformarem-se no caminho de mudança do outro. Neste sentido, a terapia tem um caráter epistêmico para todos os envolvidos - tanto clientes quanto terapeutas. A integração de recursos teóricos e técnicos constitui-se, assim, em mais um elemento pelo qual a autorreflexividade é exercida. Nos momentos em que constituímos certas ações como objeto de nossa atenção, as terapeutas refletiram sobre as implicações do uso de conhecimentos na relação terapêutica, avaliando os efeitos de suas ações nos clientes e tomando estas reflexões como orientadores para suas ações futuras.

Essas três dimensões da prática clínica indicam que a integração de determinados recursos não é uma posição que o terapeuta escolhe ocupar a priori. Ainda que um terapeuta possa descrever a própria prática como embasada em múltiplos recursos teórico-técnicos, não é possível afirmar, antecipadamente, quais recursos serão utilizados em um atendimento. Isto porque, o que um terapeuta integra relaciona-se com as conexões entre as pessoas no momento do encontro e o que isso desperta em termos do que o profissional vê como recursos úteis para construir conversas transformadoras. Desse modo, não nos colocamos, como pesquisadoras, engajadas no esforço de apresentar uma definição de integração que a generalize como fenômeno da prática clínica.

A análise das inspirações presentes nas ações das terapeutas nos indica que a integração de recursos teóricos e técnicos na prática clínica ocorreu de uma maneira relacional e responsiva. As três dimensões apresentadas caracterizam a maneira como as terapeutas integram recursos em sua prática clínica e, nesse sentido, respondem mais diretamente ao nosso segundo objetivo específico, que está voltado para a exploração das explicações construídas pelas terapeutas para o uso dos recursos, dando visibilidade às suas justificativas teóricas e articulando com a literatura da área.

Por fim, apresentamos as contribuições deste estudo para o campo acadêmico e profissional voltado para a prática em TF. Primeiramente, descrevemos ferramentas 
para estudos sobre a prática; em seguida, definimos a consistência, coerência e rigor na integração de aportes teóricos e técnicos; e, finalmente, apresentamos norteadores para a prática do terapeuta.

\subsubsection{Construindo ferramentas para investigações na prática de TF}

Essa ferramenta está voltada para o terapeuta ou pesquisador que deseja investigar a prática em pesquisa acadêmica ou em clínicas-escola no contexto de formação em TF. As dez etapas que fizeram parte da produção e análise dos dados, apresentadas no quadro 1, oferecem um modelo a ser utilizado em pesquisas no contexto clínico. Tal modelo é flexível e pode ser adaptado conforme os objetivos de cada terapeuta-pesquisador. Alguns exemplos de adaptação para uma nova construção metodológica podem ser:

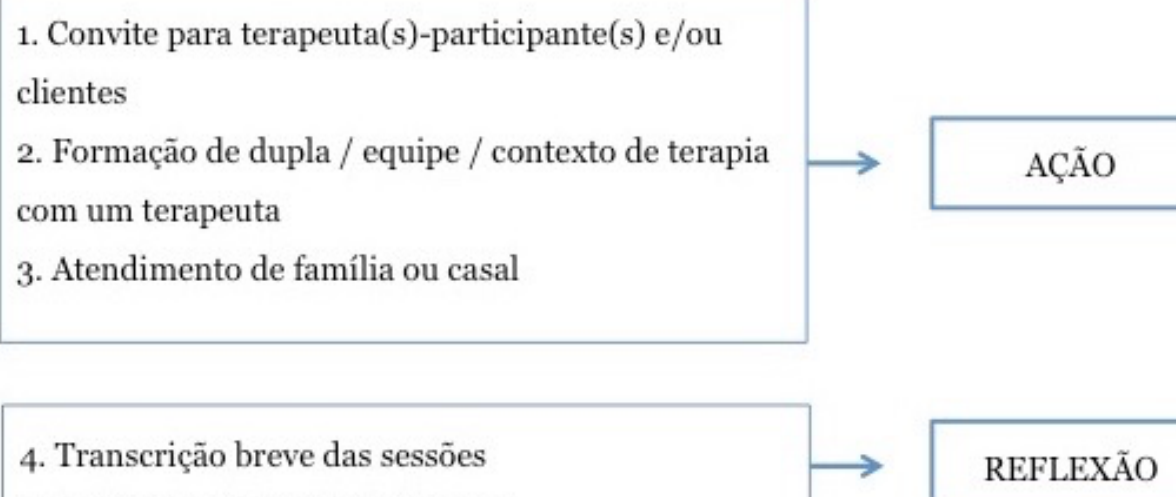

Quadro 10. Ferramenta I para investigações na prática clínica 
1. Convite para terapeuta(s)-participante(s) e/ou clientes

2. Formação de dupla / equipe / contexto de terapia com um terapeuta

3. Atendimento de família ou casal

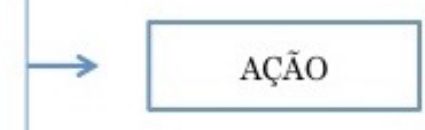

4. Interlocução pós-sessão

5. Transcrição breve da interlocução

REFLEXÃO

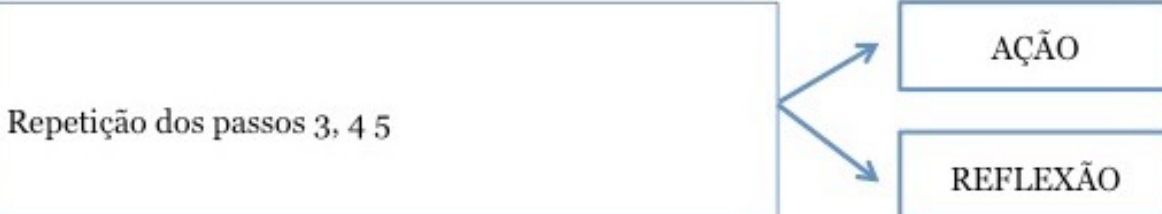

Análise do corpus

REFLEXÃO

Quadro 11. Ferramenta II para investigações na prática clínica

1. Convite para terapeuta(s)-participante(s) e/ou clientes

2. Formação de dupla / equipe / contexto de terapia com um terapeuta

AÇÃO

3. Atendimento de família ou casal

4. Transcrição breve das sessões

5. Análise das transcrições breves

6. Construção do material para interlocução pósatendimento

REFLEXÃO

7. Contato das terapeutas-participantes com o material para interlocução

\section{Interlocução pós-atendimento}

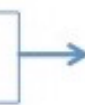

AÇÃO

9. Transcrição da interlocução

10. Análise da interlocução

Quadro 12. Ferramenta III para investigações na prática clínica 
As primeiras etapas do estudo repetem-se em todos os exemplos, consistindo no convite de participação para terapeutas e clientes, com a subsequente formação de dupla ou equipe de atendimento. Ou, ainda, o terapeuta-participante pode fazer o atendimento sozinho enquanto o pesquisador permanece no lugar de observador das sessões. A terceira etapa consiste na realização do atendimento de família. Quando compreendidas a partir da perspectiva da pesquisa-ação, essas três etapas compõem um primeiro ciclo de ação, seguida por um ciclo de reflexão.

No quadro 10, o ciclo de reflexão é composto pela transcrição das sessões e posterior análise, segundo os objetivos do estudo.

No quadro 11, a quarta etapa consiste em uma interlocução realizada após a sessão de atendimento, na qual pesquisador e terapeuta podem dialogar sobre aspectos que respondem aos objetivos do estudo. Neste delineamento, é realizada uma interlocução após cada sessão, a qual é gravada e posteriormente transcrita. Esta alternância entre sessão-interlocução-transcrição consiste na alternância entre ciclos de ação e reflexão, e culmina em um último ciclo de reflexão, na qual os dados são analisados.

O quadro 12 oferece um exemplo que utiliza as mesmas dez etapas que constituíram nosso estudo, mas que podem ser adaptadas para a consecução de outros objetivos e comportam variações quanto ao número de terapeutas atendendo no caso, tipo de material a ser entregue ao(s) terapeuta(s)-participante(s) antes da interlocução e as perguntas que norteiam a conversa de interlocução.

Este tipo de delineamento metodológico pode ser útil para um extensa gama de interesses, por exemplo: investigar as conversas internas do terapeuta, a pessoa do terapeuta nos atendimentos clínicos (p. ex. uso de história pessoal), o uso de recursos teóricos e técnicos (p. ex. uso de genograma, construção de mapa de rede social, entrevista única, uso terapêutico de cartas), análise dos processos de mudança em terapia, são alguns temas possíveis.

\subsubsection{Construindo sentidos sobre consistência, coerência e rigor}

Como afirmamos no capítulo introdutório, nosso estudo insere-se em um conjunto de debates, no campo da TF, em torno de questões como coerência, consistência e rigor na utilização de diferentes enfoques teóricos e práticos. Há, nos 
debates acerca da integração de recursos teóricos e técnicos, reflexões sobre a necessidade de se definir o que seria uma forma criativa de integração que, ao mesmo tempo, preserve o rigor, a coerência e consistência (por exemplo, Ponciano \& FéresCarneiro, 2005). Elaboramos, assim, acepções acerca destes três termos, a partir da análise realizada e de nossa inserção neste campo-tema.

Propomos que a consistência na prática clínica seja entendida como uma característica da prática que indica uma certa permanência na atuação do terapeuta em diferentes casos. A partir de nosso estudo, compreendemos que o elemento que oferece consistência à prática do profissional é o domínio de conhecimentos tanto teóricos quanto práticos acerca da $\mathrm{TF}$, e o uso desses conhecimentos de modo relacional, ou seja, a partir de uma sensibilidade às idiossincrasias do contexto, das pessoas e da forma como se estabelece (e se transforma) a relação entre terapeutas e clientes. Nesse sentido, não são os conhecimentos teóricos e técnicos que permanecem os mesmos nos diferentes atendimentos - a permanência refere-se a relacionar-se com seus conhecimentos prévios de forma flexível, circunstancial, considerando os elementos relacionais de cada encontro terapêutico, oferecendo aquilo que pode ser útil para cada pessoa, em cada momento específico.

Propomos que a coerência na prática clínica seja entendida como uma harmonia entre o que se faz e o fim a que se destina a ação. Consideramos que manter-se fiel ao interesse pragmático do terapeuta que atua em contexto clínico é o elemento que confere coerência à prática. Isto difere-se de um posicionamento em que o profissional mantem-se fiel ao modelo teórico que segue, independentemente dos clientes com quem se relaciona. Reafirmamos, assim, o caráter interpessoal na integração de conhecimentos discutido por Oddli e McLeod (2017), em que a tendência do terapeuta é utilizar os conhecimentos de forma flexível e pragmática, em um processo contínuo e guiado pelo monitoramento constante do que pode ser mais útil para os clientes.

A partir destas definições, vemos que tanto a consistência quanto a coerência referem-se a elementos que oferecem certa uniformidade no proceder. Contudo, cabe destacar que, paradoxalmente, esta uniformidade gera práticas constantemente mutáveis, uma vez que são relacionalmente responsivas.

Por fim, propomos que o rigor na prática clínica seja referido ao uso de três norteadores: 
> Reflexividade: o terapeuta mantém uma atenção constante à suas ações e aos efeitos que elas provocam nos clientes e na relação terapêutica.

> Autorreflexividade: o terapeuta mantém-se atento a si mesmo, perguntando-se pelos parâmetros para onde direciona sua fidelidade desejo aplicar corretamente um modelo? Ou desejo estar inteiramente presente nessa relação, aberto para o que ela me apresenta?

> Entendimento dos modelos teóricos como opções discursivas: o terapeuta compreende os modelos como modos de construir conversas e cada modelo seria uma voz a enriquecer a construção de conversas generativas, trazendo a polifonia como aliada nas possibilidades de transformação (McNamee, 2005).

Vemos estas propostas de consistência, coerência e rigor como guias úteis que podem orientar a integração de recursos teóricos e técnicos por parte de terapeutas, no contexto de atendimentos clínicos.

\subsubsection{Construindo orientadores para a prática clínica}

Para delinear contribuições específicas do estudo para o campo da prática profissional, propomos que uma mudança na forma de descrever a análise dos dados oferece a criação de um campo fértil de compreensão e utilização das informações produzidas em nosso estudo. É importante pontuar que não apresentamos, aqui, uma nova proposta de análise do material - diferentemente, o que descrevemos é uma nova forma de nomear as categorias e temáticas que pode favorecer o uso destas informações no contexto da prática clínica.

No quadro 9, em que sintetizamos as informações discutidas na pesquisa, a primeira coluna refere-se às categorias que criamos a partir da análise do material: ações exploratórias, ações de construção de visões relacionais, ações de construção da comunicação em contexto e ações de orientação familiar. Sob uma nova lógica, estas categorias podem ser nomeadas como recursos conversacionais para a prática terapêutica, ou seja, guias para a atenção do terapeuta, a qual está voltada para as interações, conversas e seus efeitos na relação entre terapeuta e clientes (Martins, 
McNamee \& Guanaes-Lorenzi, 2017). Neste sentido, podemos pensar que cada conjunto de ações (ou, agora, cada recurso conversacional) confere ao terapeuta uma posição em relação às interações e à conversação, que irá pautar suas perguntas, comentários, aberturas que seguirá no diálogo e outras ações. Temos, assim, quatro recursos conversacionais que definem posições para o terapeuta na relação terapêutica: posição exploratória, posição para construção de visões relacionais, posição de construção da comunicação em contexto e posição de orientação familiar. O quadro 13 apresenta esta nova forma de nomear os resultados: 
Posição exploratória
Construção de

conhecimentos que orientam

a terapeuta e a família. As

perguntas convidam os

membros a trazerem

informações, descrições e

discursos sobre eles mesmos

ou outras pessoas.
Fazer perguntas de

exploração (história do casal, terapeuta conhecer a família

história do problema,

sentimentos, desejos,

preferências, etc.)

Explorar o sentido

considerando a expressão

não-verbal

Investigar a rede social e

familiar

Fazer comentários e

perguntas apreciativas

Explorar sentimentos ou

intenções que movem ações

Explorar a exceção do problema

Explorar recursos para a superação do problema

Explorar o genograma terapeuta conhecer a fam

construir sentidos

transformadores

Construir sentidos que

integram as dimensões do

que é dito e do que

acompanha o proferimento

Explorar relações

significativas que compõem a

rede social e familiar

Destacar elementos de força competência, empenho e outros aspectos que

aproximam os clientes do que desejam ser

Explorar dimensões que estão além das ações

concretamente observadas

Investigar vivências que se opõem às narrativas do problema

Focar em recursos (utilizados anteriormente ou não)

ligados à história das pessoas com seus problemas

Explorar padrões e contextos familiares por meio da
- Postura colaborativa

(Anderson, 2016)

- Perguntas lineares (Tomm, 1988)

- Diferentes dimensões da

linguagem (Sluzki, 2016)

- Self dialógico (Gergen,

2008, 2009)

- Rede social (Sluzki, 1997)

- Investigação apreciativa

(Cooperrider, Whitney \&

Stravos, 2003; Souza,

McNamee \& Santos, 2010)

- Conversas de construção de andaimes (White, 2012)

- Conversas que iluminam eventos extraordinários (White, 2012)

- Foco pragmático da terapia e foco nas potencialidades dos clientes (Rasera \& Japur, 2004)

- Genograma (McGoldrick, Gerson \& Petry, 2012) 
Posição para construção de visões relacionais
Terapeuta faz perguntas e comentários que ampliam sentidos sobre os problemas, as pessoas e as possibilidades de mudança. Busca tornar mais complexas e relacionais as descrições sobre si e sobre o outro, iluminando novos caminhos nas dimensões do sentir e agir.
No uso do genograma, explorar a posição do cliente em relação à própria história

construção do genograma

Explorar como o cliente se posiciona, se posicionou no

passado ou é posicionado

em relação a diferentes

assuntos e vivências

Descrever ou explorar

diferentes selves de uma pessoa

Fazer pergunta de implicação

Fazer explorações epistêmicas

Explorar ou descrever o padrão comunicacional ou relacional

Questionar a ideia de um self único e permanente

das pessoas na manutenção

do problema e na busca por soluções

Buscar a construção de conhecimentos sobre si e o outro, com enfoque

transformador e generativo

Iluminar aspectos da coordenação entre as pessoas, geralmente pelas pessoas de sua família

- Genograma (McGoldrick, Gerson \& Petry, 2012)

- Personagens internos

(Lenzi, 2013)

- Self dialógico (Gergen, 2008, 2009)

- Conversas de construção de andaimes (White, 2012)

- Foco na polivocalidade

(Rasera \& Japur, 2004)

- Processos reflexivos

(Andersen, 2002)

- Perguntas circulares

(Tomm, 1988)

- Postura colaborativa

(Anderson \& Gehart, 2006) correlacionando as

dimensões do agir e do sentir
- Construção social das realidades cotidianas (McNamee, 2004)

- Exploração de padrões que conectam a família (Bateson, Jackson, Haley \& Weakland, 1956; McGoldrick, Gerson \& Petry, 2012; SelviniPalazzoli, Boscolo, Cecchin \& 


\begin{tabular}{|c|c|c|c|c|}
\hline $\begin{array}{c}\text { Recursos } \\
\text { conversacionais }\end{array}$ & Definiçãão & Ações & Descrição & Inspiração \\
\hline & & & & $\begin{array}{l}\text { Prata, 1986; Tomm, 1988; } \\
\text { Watzlawick, Beavin \& } \\
\text { Jackson, 2007) }\end{array}$ \\
\hline & & $\begin{array}{l}\text { Construir sentidos para além } \\
\text { da queixa }\end{array}$ & $\begin{array}{l}\text { Ampliar sentidos para que os } \\
\text { clientes comuniquem mais } \\
\text { diretamente seus desejos e } \\
\text { pedidos }\end{array}$ & $\begin{array}{l}\text { - Conversas de construção de } \\
\text { andaimes (White, 2012) } \\
\text { - Desconstrução da queixa e } \\
\text { construção do pedido } \\
\text { (Vicente \& Pereira, 2001) }\end{array}$ \\
\hline & & $\begin{array}{l}\text { Abordar questões sociais e } \\
\text { culturais que entrecortam o } \\
\text { problema }\end{array}$ & $\begin{array}{l}\text { Levar em consideração as } \\
\text { dimensões social, cultural e } \\
\text { histórica que fazem parte dos } \\
\text { sofrimentos e dilemas } \\
\text { humanos. }\end{array}$ & $\begin{array}{l}\text { - Terapia social (Camargo- } \\
\text { Borges, 2010) } \\
\text { - Prática clínica como uma } \\
\text { atividade política (Gergen \& } \\
\text { Warhuus, 2009) } \\
\text { - Prática envolvida em } \\
\text { desconstruir narrativas } \\
\text { opressoras (Moscheta, 2014) } \\
\text { - Trazer o social para o } \\
\text { individual (Martins, } \\
\text { McNamee \& Guanaes- } \\
\text { Lorenzi, 2017) }\end{array}$ \\
\hline & & Fazer perguntas de futuro & $\begin{array}{l}\text { Focar no que é desejado ou } \\
\text { desejável para a família, a } \\
\text { partir do que trazem como } \\
\text { situações que geram conflito }\end{array}$ & $\begin{array}{l}\text { - Prática terapêutica com } \\
\text { foco no futuro (McNamee, } \\
\text { 2004) }\end{array}$ \\
\hline & & Fazer perguntas reflexivas & $\begin{array}{l}\text { Por meio de perguntas, } \\
\text { convidar o outro a pensar } \\
\text { sobre si mesmo, sobre si } \\
\text { mesmo na relação e/ou sobre } \\
\text { relações }\end{array}$ & $\begin{array}{l}\text { Processos reflexivos } \\
\text { (Andersen, 2002) } \\
\text { - Perguntas reflexivas } \\
\text { (Tomm, 1988) }\end{array}$ \\
\hline & & Fazer comentários reflexivos & $\begin{array}{l}\text { Propor novas visões sobre as } \\
\text { pessoas e suas relações, sob }\end{array}$ & $\begin{array}{l}\text { - Processos reflexivos } \\
\text { (Andersen, 2002) }\end{array}$ \\
\hline
\end{tabular}




\begin{tabular}{|c|c|c|c|c|}
\hline $\begin{array}{c}\text { Recursos } \\
\text { conversacionais }\end{array}$ & Definiçãa & Ações & Descrição & Inspiração \\
\hline \multirow{5}{*}{$\begin{array}{l}\text { Posição para construção da } \\
\text { comunicação em contexto }\end{array}$} & \multirow{5}{*}{$\begin{array}{l}\text { Terapeuta age de forma } \\
\text { voltada à construção do } \\
\text { contexto conversacional, e } \\
\text { também pode trazer reflexões } \\
\text { sobre os efeitos da } \\
\text { comunicação desenvolvida } \\
\text { em terapia }\end{array}$} & & $\begin{array}{l}\text { um ponto de vista mais } \\
\text { complexo }\end{array}$ & \\
\hline & & Fazer um reenquadramento & $\begin{array}{l}\text { Oferecer novas perspectivas } \\
\text { sobre o que é dito, tornando } \\
\text { as descrições relacionais, } \\
\text { reduzindo polarizações }\end{array}$ & $\begin{array}{l}\text { - Reenquadramento } \\
\text { (Minuchin, 1980) } \\
\text { - Conversas de construção de } \\
\text { andaimes (White, 2012) }\end{array}$ \\
\hline & & Coordenar a conversa & $\begin{array}{l}\text { Atuar no fluxo } \\
\text { comunicacional para tornar a } \\
\text { conversa distinta do que os } \\
\text { clientes habitualmente têm } \\
\text { em sua vida cotidiana }\end{array}$ & $\begin{array}{l}\text { - Responsabilidade relacional } \\
\text { (McNamee \& Gergen, 1999) }\end{array}$ \\
\hline & & Metacomunicar & $\begin{array}{l}\text { Comunicar sobre a } \\
\text { comunicação, cujo tema pode } \\
\text { ser a própria conversa ou, } \\
\text { também, o que a conversa } \\
\text { provoca nas pessoas }\end{array}$ & $\begin{array}{l}\text { - Comunicação humana } \\
\text { (Watzlawick, Beavin \& } \\
\text { Jackson, 2007) } \\
\text { - Metaperguntas (Tomm, } \\
\text { 1988) } \\
\text { - Teoria do posicionamento } \\
\text { (Davies \& Harré, 1990) }\end{array}$ \\
\hline & & $\begin{array}{l}\text { Utilizar a co-terapia como } \\
\text { recurso para a comunicação }\end{array}$ & $\begin{array}{l}\text { Utilizar a co-terapia como } \\
\text { recurso para a construção do } \\
\text { contexto conversacional }\end{array}$ & $\begin{array}{l}\text { - Equipe reflexiva (Andersen, } \\
\text { 2002) }\end{array}$ \\
\hline \multirow[t]{2}{*}{$\begin{array}{l}\text { Posição de orientação } \\
\text { familiar }\end{array}$} & \multirow{2}{*}{$\begin{array}{l}\text { Terapeuta intervêm sobre o } \\
\text { problema da família a partir } \\
\text { de um lugar de especialista, } \\
\text { embasando a conversa em } \\
\text { alguns conhecimentos } \\
\text { prévios }\end{array}$} & Oferecer informações & $\begin{array}{l}\text { Orientar os clientes acerca de } \\
\text { algum assunto, lançando } \\
\text { mão de conhecimentos } \\
\text { científicos }\end{array}$ & $\begin{array}{l}\text { - Terapeuta como especialista } \\
\text { relacional (Doricci, Crovador } \\
\text { \& Martins, 2017) }\end{array}$ \\
\hline & & Dar tarefas & $\begin{array}{l}\text { Indicar ou explorar ações que } \\
\text { devem ser realizadas por } \\
\text { cada pessoa }\end{array}$ & $\begin{array}{l}\text { - Diretivas terapêuticas } \\
\text { (Haley, 1976) } \\
\text { - Conversa de construção de } \\
\text { andaimes (White, 2012) }\end{array}$ \\
\hline
\end{tabular}

Quadro 13. Recursos conversacionais para a prática do terapeuta familiar 
O leitor pode perceber que as definições de cada recurso conversacional é idêntica à descrição das categorias do estudo, agora apresentadas na segunda coluna do quadro 13. Na terceira coluna, onde líamos "temáticas" no quadro 9, agora vemos o termo "ações". Assim, cada recurso conversacional oferece posições específicas para o terapeuta, a partir da qual ações tornam-se possíveis no contexto da relação terapêutica. As definições de cada ação permanecem as mesmas, indicadas na quarta coluna do quadro 13. Por fim, a quinta coluna apresenta recursos teóricos com os quais os terapeutas podem dialogar como inspirações para as ações. Nesse caso, ao invés de serem entendidas como inspirações descritas a posteriori a partir da análise das sessões, como fizemos em nosso estudo, estas inspirações podem ser entendidas como norteadores teóricos para estudo e articulação teórico-prática por parte dos profissionais.

Estas três contribuições do estudo, descritas em termos de possibilidades metodológicas e norteadores para a prática em TF, dialogam com a escolha da pesquisa-ação como inspiração para o delineamento teórico-metodológico. Sob esse prisma, as pesquisas acadêmicas partem de um intercâmbio com a prática e seus resultados devem dialogar com as necessidades e o cotidiano profissional (Levin, 2012). Por isso, consideramos extremamente relevante que a construção da tese, enquanto produto da atividade acadêmica, incluísse discussões que dialogam mais diretamente com os interesses da prática profissional de terapeutas familiares. 


\section{Considerações finais}

A presente pesquisa teve como objetivo geral compreender como terapeutas familiares integram teorias e técnicas como recursos para a prática clínica, em seu cotidiano de atendimentos. Especificamente, buscamos descrever os recursos técnicos e teóricos utilizados pelas profissionais, e refletir sobre as explicações construídas por elas em relação ao uso dos recursos, explicitando suas justificativas teóricas e fazendo uma articulação com a literatura da área. Para tanto, construímos um delineamento teórico-metodológico inspirado na pesquisa-ação e sensível às contribuições do construcionismo social para a prática científica. Desse modo, tanto a criação dos objetivos e métodos quanto a produção e análise dos dados buscaram dialogar com as especificidades e interesses da prática profissional em TF. A noção de ética dialógica acompanhou a construção da relação com os participantes, tanto terapeutas quanto clientes - para além das diretrizes normativas, novas diretrizes foram criadas para atender as especificidades e cuidados necessários à prática em contexto de clínica privada.

O rigor na prática científica foi acompanhado pela preocupação em construir saberes relevantes para distintos contextos, e as formas de descrição dos resultados buscaram dialogar com a comunidade acadêmica e profissional (e, nesse sentido, também com as terapeutas-participantes). As categorias criadas no processo analítico respondem a este duplo interesse da pesquisa, pois podem ser compreendidas tanto sob o ponto de vista de categorias e temáticas, quanto como recursos conversacionais e ações para a prática do terapeuta familiar. O delineamento metodológico também é potente em termos de suas contribuições para estes dois campos: na pesquisa científica, pode gerar conhecimentos úteis para a comunidade acadêmica e para profissionais; quando adaptado para contextos de formação em TF, 
pode tornar-se um modelo de investigação de diversos aspectos da prática clínica do terapeuta.

No que se refere à tese como produto da investigação científica, destacamos seu caráter como uma produção sensível às formas alternativas de redação de textos científicos (M. Gergen \& K. Gergen, 2000). A alternância entre os ciclos de ação e reflexão geraram diferentes níveis de análise das informações, representados pela variação nos recuos de texto. Como resultado, temos um texto orientado por uma estética que dá visibilidade à complexidade das informações e do processo analítico realizado.

Os meios de divulgação da tese também estão orientados pela lógica da pesquisa-ação. A publicação de artigos em periódicos indexados é uma maneira de circular o relato da pesquisa no meio acadêmico e busca atender ao compromisso ético da prática da pesquisa no que se refere à divulgação de estudos. Além disso, investiremos nossos esforços na publicação em revistas voltadas para o público profissional, sobretudo aquelas de maior circulação entre terapeutas familiares brasileiros, com o foco voltado para os aspectos do estudo que dialogam mais diretamente com o cotidiano da prática clínica. Por fim, cada terapeuta-participante receberá um exemplar impresso da tese, por considerarmos que o produto final da pesquisa é fruto de um trabalho conjunto com Lina e Anna, as quais posicionaram-se (e foram posicionadas) como co-pesquisadoras no processo analítico e contribuíram com a consecução do estudo por meio de seu envolvimento e dedicação.

Em relação ao nosso objeto de estudo - a prática clínica em TF - algumas considerações podem ser realizadas. Nossa pesquisa está situada no território dos debates acerca da relação entre teoria e prática. Os resultados parecem corroborar com as colocações de Flaskas (2005) a este respeito, o qual afirma ser necessário expandir o entendimento da teoria como "base" da prática. O autor descreve a relação entre ambas a partir da imagem de uma espiral, havendo entre elas uma influência contínua e recíproca. Entendendo a TF como uma disciplina prática, Flaskas (2005) afirma que neste campo a prática vem antes no processo de construção de conhecimento, isto é, a teoria parece dar forma e informar a prática a posteriori na medida em que o terapeuta esforça-se por descrever o que fez e produzir sentidos sobre suas ações. Nesse âmbito, nosso estudo dá visibilidade à riqueza que pode emergir a partir do caos envolvido no mergulho que realizamos em nossas próprias 
ações, buscando não apenas descrevê-las, mas produzir sentidos sobre estas ações em termos deste intercâmbio entre teoria e prática.

No tocante aos nossos objetivos, voltados para a questão da integração de recursos teóricos e técnicos no contexto da prática, o estudo indica que o uso de múltiplos aportes foi importante não só para o manejo clínico, oferecendo às terapeutas diferentes recursos pelos quais puderam construir e manter-se em relação com os clientes, mas também como uma forma de serem responsivas às demandas dos clientes, que são diversas e complexas, e variam de caso a caso. As três dimensões que caracterizaram a forma pela qual Lina e Anna integraram recursos em sua prática - de forma sensível ao contexto e às pessoas, engajada em produzir conhecimentos com as pessoas, e autorreflexiva - indicam o que entendemos como uma maneira relacional de lidar com os conhecimentos, por manterem-se abertas às vicissitudes do encontro terapêutico e à própria transformação no momento-a-momento das sessões.

A partir dessas considerações, reafirmamos algumas reflexões presentes no campo em relação à viabilidade de um terapeuta constituir-se como um "purista" em relação ao uso de diferentes modelos. Nosso estudo corrobora a ideia de que os múltiplos recursos utilizados por um terapeuta presentificam-se como vozes que podem enriquecer o diálogo no encontro terapêutico, aumentando as possibilidades pelas quais o profissional pode conectar-se com as histórias e vivências dos clientes e corresponsabilizar-se na construção de caminhos de transformação (Asen, 2004; Flaskas, 2005; Hickman et al, 2009; Oddli \& McLeod, 2017; Paula-Ravagnani, Guanaes-Lorenzi \& Rasera, 2017; Smith \& Southern, 2005; Snyder \& BalderramaDurbin, 2012; Solomonov et al, 2016; Strong, 2002).

Nesse ponto, é importante reafirmar nossa compreensão da integração como uma posição de abertura do terapeuta para o caos e a impermanência dos encontros humanos, nos quais tanto os conhecimentos teórico-práticos quanto os conhecimentos tácitos podem constituir-se em recursos úteis para a construção das transformações desejadas. Essa concepção difere-se da ideia da integração como a criação de um meta-enquadre, em que as contribuições teóricas e técnicas são organizadas em um novo modelo guiado por uma inteligibilidade que explica porquê tais elementos foram conectados (Lebow, 2014; Pinsof, 1992).

Em relação ao campo de investigação no qual o estudo está inserido, a terapia familiar, vemos que esse é um tema de interesse que entrecorta a produção de conhecimento desde seu início. Considerações acerca da integração podem ser 
encontradas tanto nas obras clássicas da época de criação do campo - por exemplo, as ideias presentes em Satir (1967) - quanto em publicações em diversos países do mundo - por exemplo, Noruega (Lorås \& Sundelin, 2018, Oddli \& McLeod, 2017), Estados Unidos da América (Hickman et al, 2009; Snyder \& Balderrama-Durbin, 2012; Solomonov et al, 2016), Austrália (Flaskas, 2005), Reino Unido (Asen, 2004) e Brasil (Paula-Ravagnani et al, 2016; Paula-Ravagnani, Guanaes-Lorenzi \& Rasera, 2017; Ponciano \& Féres-Carneiro, 2005; Prati \& Koller, 2012). Vemos que a discussão dessa temática tanto é desejável como também é multifacetada. O contato com essa literatura parece nos indicar que os autores, comentadores e profissionais que já discutiram ou têm discutido a questão da integração parecem andar longe do objetivo de produzir consensos. Diferentemente, o interesse parece aproximar-se da preocupação em construir práticas que sejam críticas e reflexivas, voltadas para o interesse de oferecer o melhor possível para os clientes que buscam a TF.

Nosso estudo possui limitações a serem ressaltadas. Primeiramente, a discussão dos resultados deixa evidente o uso de ideias alinhadas com o pensamento sistêmico e práticas pós-modernas sensíveis ao construcionismo social. Este caráter dos dados foi definido pelo próprio delineamento do estudo, em que optamos por convidar terapeutas cuja formação e atuação clínica fossem próximas daquelas da terapeutapesquisadora. Essa escolha esteve pautada, primordialmente, na necessidade de existência de um vocabulário que fosse minimamente compartilhado em termos de aportes para a prática clínica, tornando mais viável a construção da dupla de terapeutas e os diálogos sobre o caso.

O foco das ações também pode ver visto sob o prisma de uma limitação do estudo. $\mathrm{O}$ olhar sobre o processo de produção de sentidos necessariamente inclui as suplementações sucessivas entre os interlocutores (K. Gergen, 2009). Nossa escolha, ao priorizar um dos aspectos que constituem a relação terapêutica - aquilo que o terapeuta diz e faz - não abarca as suplementações dos clientes e como estas foram co-construindo as ações das terapeutas.

Os passos que constituem nosso processo analítico também configuram alguns limites que devem ser considerados. A alternância entre ciclos de ação e reflexão demandou períodos em que a pesquisadora dedicou-se à análise dos dados e construção de materiais que nortearam as etapas seguintes. Esse aspecto gerou um lapso de tempo entre a ação e o momento em que refletimos sobre ela. Com isso alguns aspectos e detalhes são simplesmente esquecidos pelo passar do tempo, o que 
pode gerar conversas com menor riqueza e detalhamento, sobretudo em relação à possibilidade de resgatar, na interlocução, ideias e conversas internas dos terapeutas no momento do atendimento. Além disso, os múltiplos passos também ocasionam a produção de um extenso corpus a ser analisado. Considerando a dimensão "artesanal" do processo analítico, esse formato pode dificultar a inclusão de um número maior de participantes.

A finalização do estudo oferece caminhos e perspectivas para novas pesquisas. Pesquisas que expandam o foco de observação daquilo que é compreendido como "recurso" para a prática do terapeuta podem oferecer reflexões interessantes para o campo. Isto é, para além dos recursos teórico-técnicos, incluir a análise de qualquer tipo de conhecimento que o terapeuta tenha considerado válido no momento do atendimento - por exemplo, experiências pessoais do terapeuta.

Em termos de orientação metodológica de futuras pesquisas, consideramos que a compreensão da TF como disciplina prática (Flaskas, 2005) nos convida, como acadêmicos, a construir pesquisas que sejam relevantes para os profissionais (cujos interesses, via de regra, são diferentes daquelas temáticas caras à comunidade acadêmica). Estudos embasados na pesquisa-ação oferecem caminhos promissores nesse sentido.

Por fim, assim como toda ação e produção (científica ou clínica) no campo da $\mathrm{TF}$, essa pesquisa é mais um elemento que contribui para a constituição e caracterização do campo, e ajuda a construir o momento presente e futuro da TF. Esperamos que as ressonâncias dessas contribuições na comunidade acadêmica e profissional possam contribuir para a ampliação de nossas reflexões e para a construção de novos orientadores pelos quais podemos conversar sobre nossas práticas, sempre orientadas por uma ética dialógica. As análises, reflexões e definições presentes nessa tese são transitórias e referidas aos conhecimentos que, até o momento, fazem parte do nosso diálogo com esse campo-tema. O próprio processo de escrita parece já nos oferecer aberturas para questionamentos e mudanças. Assim, esperamos que as produções científicas e as trocas entre terapeutas e acadêmicos possam oferecer ampliações e refinamentos dos parâmetros aqui apresentados, considerados relevantes no contexto da prática clínica. 


\section{Referências $^{10}$}

Andersen, T. (2002). Processos reflexivos (2a ed). Rio de Janeiro: Instituto Noos.

Anderson, H. (1997). Conversation, language, possibilities: A postmodern approach to therapy. New York: Basic Books.

Anderson, H. (2016). A postura filosófica: o coração e a alma da terapia colaborativa. In M. A. Grandesso (Org). Práticas colaborativas e dialógicas em distintos contextos e populações: um diálogo entre teorias e práticas (pp. 19-32). Curitiba, CRV.

Anderson, H., \& Goolishian, H. (1988). Human systems as linguistic systems: Preliminary and evolving ideas about the implications for clinical theory. Family Process, 27(4), 371-93.

Anderson, H., \& Goolishian, H. (1992). The cliente is the expert: a not-knowinh approach to therapy. In S. McNamee \& K. J. Gergen (Orgs.), Therapy as social construction (pp. 25-39). London: Sage Publications.

Anderson, H., \& Gehart, D. (2006). Collaborative Therapy: Relationships and conversations that make a difference. London: Routledge.

Arieli, D., Friedman, V. J., \& Agbaria, K. (2009). The paradox of participation in action research. Action Research, $7(3), 263-90$.

${ }^{10}$ De acordo com o estilo APA - American Psychological Association 
Asen, E. (2004). Collaborating in promiscuous swamps: the systemic practitioner as context chameleon? Journal of Family Therapy, 26, 280-5.

Aun, J. G. (2012). Da terapia de família ao atendimento sistêmico à família. In J. G. Aun; M. J. E. Vasconcellos \& S. V. Coelho, Atendimento sistêmico de famílias e redes sociais: fundamentos teóricos e epistemológicos (Vol. 1). Belo Horizonte: Ophicina de Arte e Prosa. (Trabalho original publicado em 2005).

Bardal, D. (2008). Action research: A paradigm for achieving social change. Action Research, 39(1), 17-27.

Bateson, G., Jackson, D., Haley, J., \& Weakland, J. (1956). Toward a theory of schizophrenia. Behavioral Science, 1, 251-64.

Bertalanffy, L. V. (2008). Teoria geral dos sistemas: fundamentos, desenvolvimento e aplicações (8. Ed.). Petrópolis, RJ: Vozes. (Original publicado em 1968)

Biernacki, B., \& Waldorf, D. (1981). Snowball Sampling. Sociological Methods and Research, 1O(2), 141-163.

Brasil, Ministérios da Saúde (2012). Resolução no 466/2012. Brasília: Conselho Nacional de Saúde.

Brydon-Miller, M., Greenwood, D. J., \& Maguire, P. (2003) Why action research? Action Research, 1(1), 9-28.

Burr, V. (2003). Introduction to social constructionism (2nd ed). Nova York: Routledge.

Camargo-Borges, C. (2010). Terapia social: desenvolvimento humano e mudança social. Arquivos Brasileiros de Psicologia, 62(3), 48-58. 
Castelló, B. V. (2016). Bridging constructivism and social constructionism: The journey from narrative to dialogical approaches and toward synchrony. Journal of Psychotherapy Integration, 26(2), 129-43. doi 10.1037/intooooo25

Cecchin, G. (1989). Nueva visita a la hipotetización, la circularidad y la neutralidad : una invitación a la curiosidad. Sistemas Familiares, 9-17.

Cooperrider, D. L., Whitney, D., \& Stavros, J. M. (2003). The appreciative inquiry handbook. Bedford: Lakeshore Communications.

Corradi-Webster, C. M. (2009). Consumo problemático de bebidas alcoólicas por mulheres: discursos e histórias. Tese de Doutorado, Faculdade de Filosofia, Ciências e Letras de Ribeirão Preto, Universidade de São Paulo, Ribeirão Preto. doi 10.11606/T.59.2009.tde-03062011-142952

Costa, L. F. (2010). A perspectiva sistêmica para a clínica da família. Psicologia: Teoria e Pesquisa, 26(n.esp.), 95-104.

Fiorini, M. C., Guisso, L., \& Crepaldi, M. A. (2017). O trabalho com equipes reflexivas: revisão de literatura. Revista Nova Perspectiva Sistêmica, 57, 85-102.

Dallos, R., \& Urry, A. (1999). Abandoning our parents and grandparents: Does social constructionism mean the end of systemic family therapy? Journal of Family Therapy, 21, 161-86.

Davies, B., \& Harré, R. (1990). Positioning: The discursive production of selves. Journal for the Theory of Socual Behavior, 20(1), 43-63.

Davis, S. D., Lebow, J. L., \& Sprenkle, D. H. (2012). Common factors of change in couple therapy. Behavior Therapy, 43, 36-48.

Dick, B., \& Greenwood, D. J. (2015) Theory and Method: Why action research does not separate them. Action Research, 13(2), 194-197. 
Dickerson, V. C. (2010). Positioning oneself within an epistemology: Refining out thinking about integrative approaches. Family Process, 49, 3, 349-368.

Dickerson, V. (2014). The advance of poststructuralism and its influence on family therapy. Famíly Process, 53(3), 401-14. doi 10.1111/famp.12087

Diniz-Neto, O., \& Féres-Carneiro, T. (2005). Eficácia terapêutica e o efeito "Dodô". Estudos de Psicologia, 1o(3), 355-61.

Doricci, G. C., Crovador, L. F., \& Martins, P. P. S. (2017). O especialista relacional na terapia familiar de fundamentação epistemológica construcionista social. Revista Nova Perspectiva Sistêmica, 59, 37-51.

Faugier, J., \& Sargeant, M. (1997). Sampling hard to reach populations. Journal of Advanced Nursing, 26, 790-97.

Féres-Carneiro, T. (1996). Terapia familiar: das divergências às possibilidades de articulação dos diferentes enfoques. Psicologia Ciência e Profissão, 16, 38-42.

Flaskas, C. (2005). Relating to knowledge: challenges in generating and using theory for practice in family therapy. Journal of Family Therapy, 27, 185-201.

Flaskas, C. (2010). Frameworks for practice in the systemic field: Part 1 Continuities and transitions in family therapy knowledge. Australian and New Zealand Journal of Family Therapy, 31(3), 232-47.

Flaskas, C. (2011). Frameworks for practice in the systemic field: Part 2 Contemporary frameworks in family therapy. Australian and New Zealand Journal of Family Therapy, 32(2), 87-108. DOI 10.1375/anft.32.2.87

Gergen, K. J. (1985). The social constructionism movement in modern psychology. American Psychologist, 266-275. 
Gergen, K. J. (2008). Therapeutic challenges of multi-being. Journal of Family Therapy, 3o, pp. 333-348.

Gergen, K. J. (2009). Relational Being: Beyond Self and Community. New York: Oxford University Press.

Gergen, K. J. (2014). From mirroring to world making: Research as future forming. Journal for the Theory of Social Behavior, 45, 287-310. doi 10.1111/jtsb.12075.2008.

Gergen, M., \& Gergen, K. J. (2000). Qualitative inquiry: tensions and transformations. In N. Denzin \& Y. Lincoln. (Eds). Handbook of qualitative research (2nd ed.) (pp. 1025-46). Thousand Oaks, CA: Sage.

Gergen, K. \& Warhuus, L. (2001). Terapia como construção social: características, reflexões e evoluções. In M. M. Gonçalves \& O. F. Gonçalves (Orgs). Psicoterapia, Discurso e Narrativa: a construção conversacional da mudança (pp. 27-64). Coimbra: Quarteto Editora.

Goetz, J. P., \& LeCompte, M. D. (1984). Etnography and qualitative design in educational research. Orlando, FL: Academic Press.

Gomes, I. C., \& Levy, L. (2009). Psicanálise de família e casal: principais referenciais teóricos e perspectivas brasileiras. Aletheia, 29, 151-61.

Gourman, A. L. (2011). Couple therapy research and the practice of couple therapy: Can we talk? Family Process, 5o(3), 280-92.

Grandesso, M. (2006). Sobre a reconstrução do significado: uma análise epistemológica e hermenêutica da prática clínica. São Paulo: Casa do Psicólogo.

Grandesso, M. (2009). Desenvolvimentos em terapia familiar: das teorias às práticas e das práticas às teorias. In L. C. Osório \& M. E. P. Valle (Orgs.). Manual de Terapia Familiar (pp. 104-118). Porto Alegre: Artmed. 
Guanaes, C. (2006). A construção da mudança em terapia de grupo: um enfoque construcionista social. São Paulo: Vetor.

Guanaes-Lorenzi, C., Moscheta, M. S., Corradi-Webster, C. M., \& Vilela, L. (2014). Construcionismo social: discurso, prática e produção do conhecimento. Rio de Janeiro: Instituto Noos.

Gunther, H. (2006). Pesquisa qualitativa versus pesquisa quantitativa: esta é a questão? Psicologia: Teoria e Pesquisa, 22(2), 201-10.

Haene, L. (2010). Beyond division: Convergences between postmodern qualitative research and family therapy. Journal of Marital and Family Therapy, 36(1), 1-12. DOI 10.111/j.1752-0606.2009.00174.x

Haley, J. (1976). Psicoterapia familiar. Belo Horizonte: Interlivros.

Hickman, E. E., Arnkoff, D. B., Glass, C. R., \& Schottenbauer, M. A. (2009). Psychotherapy integration as practiced by experts. Psychotherapy, Theory, Research, Practice, Training, 46(4), 486-91.

Hintz, H. C., \& Souza, M. O. (2009). A terapia familiar no Brasil. In L. C. Osório \& M. E. P. Valle (Orgs.). Manual de Terapia Familiar (pp. 91-103). Porto Alegre: Artmed.

Hoffman, L. (1998). Uma postura reflexiva para a terapia de família. In S. McNamee \& K. J. Gergen, A terapia como construção social (pp.14-33). Porto Alegre: Artes Médicas.

Houaiss, A. (2009). Dicionário Houaiss da língua portuguesa. Rio de Janeiro: Objetiva.

Huang, H. B. (2010). What is good action research? Action Research, 8(1), 93-109. 
Ibañez, T. (1994). La construcción del conocimento desde una perspectiva socioconstruccionista. In M. Montero (Org.). Conocimento, Realidad e Ideologia. Venezuela: Associacion Venezolana de Psicología Social.

Imber-Black, E. (2014). Eschewing certainties: The creation of family therapists in the $21^{\text {st }}$ century. Family Process, 53(3), 371-79. doi: 10.1111/famp.12091

Kvale, S. (1992). Postmodern psychology: A contradiction in terms? In . (Ed). Psychology and postmodernism (pp. 31-57). London: Sage Publications.

Lebow, J. (1988). Research into practice/ Practice into research. Journal of Family Psychology, 1(3), 337-51.

Lebow, J. (2014). The integrative perspective. In . Couple and family therapy: An integrative map of the territory (pp. 25-53). Washington, D.C.: American Psychological Association.

Lenzi, T. P. (2013). Personagens internos. Revista Nova Perspectiva Sistêmica, 22(47), 86-98.

Levin, M. (2012). Academic integrity in action research. Action Research, 1O(2), 13349. doi 10.1177/1476750312445034

Lewin, K. (1965). Teoria de campo em ciência social. São Paulo: Pioneira.

Lorås, L. \& Sundelin, J. (2018). The multi-epistemological systemic therapist: A qualitative study. Australian and New Zealand Journal of Family Therapy, 1-13. Doi 1.1002/anzf.1335

Macedo, R. M. S. (2008). Terapia familiar no Brasil na última década. São Paulo: Roca. 
Martins, P. P. S., McNamee, S., \& Guanaes-Lorenzi, C. (2017). Conversational resources for clinical practice with families: Social constructionism in action. Australian and New Zealand Journal of Family Therapy, 38(3), 433-45. Doi 10.1002/anzf.1231

Maturana, H., \& Varela, F. (1995). A árvore do conhecimento: as bases biológicas da compreensão humana. São Paulo: Palas Athena.

Maturana, H. (2002). Emoções e linguagem na educação e na política. Belo Horizonte: Editora UFMG.

McGoldrick, M., Gerson, R., \& Petry, S. (2012). Criação de Genogramas. In . Genogramas (pp. 36-70). 3. Ed. Porto Alegre: Artmed.

McNamee, S. (2001). Reconstruindo a terapia num mundo pós-moderno: recursos relacionais. In M. M. Gonçalves \& O. F. Gonçalves (Orgs). Psicoterapia, Discurso e Narrativa: a construção conversacional da mudança (pp. 236-264). Coimbra: Quarteto Editora.

McNamee, S. (2004a). Promiscuity in the practice of family therapy. Journal of Family Therapy, 26, 224-44.

McNamee, S. (2004b). Therapy as social construction: back to basis and forward toward challeging issues. In: T. Strong \& D. Pare. Furthering talk: advances in the discursive therapy. New York: Kluwer Academic/Plenum Press.

McNamee, S. (2010). Research as social construction: transformative inquiry. Saúde e Transformação Social, Florianópolis, 1(1), 9-19.

McNamee, S. (2014). Construindo conhecimento/construindo investigação: coordenando mundos de pesquisa (P.P.S. Martins, trad.). In C. Guanaes-Lorenzi, M. Moscheta, C. M. Corradi-Webster \& L. V. Souza (Orgs), Construcionismo social: discurso, prática e produção do conhecimento (pp.105-32). Rio de Janeiro: Instituto Noos. 
McNamee, S. (2015). Ethics as discursive potential. Australian and New Zealand Journal of Family Therapy, 36, 419-33.

McNamee, S., \& Gergen, K. J. (Orgs.). Therapy as social construction. London: Sage Publications.

McNamee, S., \& Gergen, K. J. (1998). A terapia como construção social. Porto Alegre: Artes Médicas.

McNamee, S. \& Gergen, K. J. (1999). Relational responsibility: Resources for sustainable dialogue. Sage Publications.

McNamee, S., \& Hosking, D. M. (2012). Research and Social Change. New York: Routledge.

Minuchin, S. (1982). Famílias: funcionamento e tratamento. Porto Alegre: Artes Médicas.

Minuchin, S. (1990). Reenquadramento. In S. Minuchin, \& H. C. Fishman. Técnicas de terapia familiar (pp. 80-83). Porto Alegre: Artmed.

Minuchin, S., Lee, W., \& Simon, G. (2008). Dominando a terapia familiar. Porto Alegre: Artes Médicas.

Moscheta, M. (2014). A pós-modernidade e o contexto para a emergência do discurso construcionista social. In C. Guanaes-Lorenzi; M. Moscheta; C. M. CorradiWebster \& L. V. Souza (Orgs). Construcionismo social: discurso, prática e produção do conhecimento (pp.23-48). Rio de Janeiro: Instituto Noos.

Oddli, H. W., \& McLeod, J. (2017). Knowing-in-Relation: How experienced therapists integrate different sources of knowledge in actual clinical practice. Journal of Psychotherapy Integration, 27, 107-119. Doi 10.1037/intoooo045 
Ollaik, L. G., \& Zimmer, H. M. (2012). Concepções de validade em pesquisas qualitativas. Educação e Pesquisa, 38(1), 229-41.

Palazzoli, M. S., Prata, G., Boscolo, L. \& Cecchin, G. (1980). Hipothesizingcircularity-neutrality: three guidelines for the conductor of the session. Family Process, 19(1), 3-12.

Paula-Ravagnani, G. S. (2015). Difusão do construcionismo social entre terapeutas familiares: desafios e potencialidades. Dissertação de Mestrado, Faculdade de Filosofia, Ciências e Letras de Ribeirão Preto, Universidade de São Paulo, Ribeirão Preto.

Paula-Ravagnani, G. S., Guanaes-Lorenzi, C., McNamee, S., \& Rasera, E. F. (2016). Social constructionist discourse in clinical practice of family therapists. Psicologia em Estudo, 21(2), 267-78.

Paula-Ravagnani, G. S., Guanaes-Lorenzi, C., \& Rasera, E. (2017). Use of theoretical models in Family Therapy. Paidéia, 27(67), 84-92.

Pinsof, W. M. (1992). Toward a scientific paradigm for family psychology: The integrative process systems perspective. Journal of Family Psychology, 5(3), 432447 .

Ponciano, E. L. T., \& Féres-Carneiro, T. (2005). Articulando diferentes enfoques teóricos na terapia familiar. Revista Interamericana de Psicologia, 39(3), 439448.

Ponciano, E. L. T., \& Féres-Carneiro, T. (2006). Terapia de família no Brasil: uma visão panorâmica. Psicologia: Reflexão e Crítica, 19(2), 252-60.

Prati, L. E., \& Koller, S. H. (2012). Práticas de terapia de família no Brasil. In M. N. Baptista \& M. L. M. Teodoro, Psicologia de família: teoria, avaliação $e$ intervenção. Porto Alegre: Artmed. 
Ragland, B. B. (2006). Positioning the practitioner-researcher: five ways of looking at practice. Action Research, 4(2), 165-82.

Rapizo, R. (2002). Terapia Sistêmica de Família (2a ed). Rio de Janeiro: Instituto NOOS.

Rasera, E. F., \& Guanaes, C. (2006). O terapeuta como produtor de conhecimento. Nova Perspectiva Sistêmica, 26, 76-85.

Rasera, E. F. \& Japur, M. (2004) Desafios da aproximação do construcionismo social ao campo da psicoterapia. Estudos de Psicologia, 9(3), 431-39.

Rasera, E. F., \& Japur, M. (2007). Grupo como construção social: aproximações entre construcionismo social e terapia de grupo. São Paulo: Vetor.

Reason, P. \& Torbert, W. R. (2001). The action turn: Toward a transformational social science. Concepts and Transformation, 6(1), 1-27.

Reason, P. \& Bradbury, H. (2008). The Sage Handbook of Action Research: Participative inquiry and practice (2nd ed.). London: Sage Publications.

Rhodes, P. (2012). Nothing to fear? Thoughts on the history of family therapy and the potential contribution of research. The Australian and New Zealand Journal of Family Therapy, 33(2), 171-82.

Satir, V. (1967). Conjoint Family Therapy. Palo Alto: Science and Behavior Books.

Sexton, T. L., \& Datchi, C. (2014). The development and evolution of family therapy research: Its impact on practice, current status and future directions. Family Process, 53(3), 415-33.

Shotter, J. (2000). Conversational realities: constructing life through language. London: Sage Publications. 
Shotter, J. (2008). Conversational realities revisited: Life, language, body and world. Chagrin Falls: Taos Institute Publications.

Shotter, J. (2011). Getting it. Withness thinking and the dialogical... in practice. New York: Hampton Press.

Smith, R. L., \& Southern, S. (2005). Integrative confusion: An examination of integrative models in couple and family therapy. The Family Journal: Counseling and Therapy for Couples and Families, 13(4), 392-99.

Snyder, D. K., \& Balderrama-Durbin, C. (2012). Integrative approaches to couple therapy: Implications for clinical practice and research. Behavior Therapy, 43, 1324 .

Souza, L. V., McNamee, S., \& Santos, M. A. (2010). Avaliação como construção social: investigação apreciativa. Psicologia \& Sociedade, 22(3), 598-607.

Sluzki, C. E. (1997). A rede social: proposições gerais. In . A rede social na prática sistêmica: alternativas terapêuticas (pp. 37-66). São Paulo: Casa do Psicológo.

Sluzki, C. (2016). Proxemics in couple interactions: Rekindling an old optic. Family Process, 55(1), 7-17. doi: 10.1111/famp.12196

Spink, M. J. P., \& Lima, H. (2013). Rigor e visibilidade: a explicitação dos passos da interpretação. In M. J. P. Spink (Org.), Práticas discursivas e produção de sentidos: aproximações teóricas e metodológicas (pp. 85-113), São Paulo: Cortez. (Original publicado em 1999)

Spink, M. J. P., \& Medrado, B. (2013). Produção de sentidos no cotidiano: uma abordagem teórico-metodológica para análise das práticas discursivas. In M. J. P. Spink (Org.). Práticas discursivas e produção de sentidos no cotidiano: aproximações teóricas e metodológicas (pp. 22-41). Rio de Janeiro: Centro Edelstein de Pesquisas Sociais. (original publicado em 1999). 
Spink, M. J. P., \& Menegon, V. M. (2013). A pesquisa como prática discursiva: superando os horrores metodológicos. In M. J. P. Spink (Org.), Práticas discursivas e produção de sentidos: aproximações teóricas e metodológicas (pp. 42-70), São Paulo: Cortez. (Original publicado em 1999)

Spink, P. (2003). Pesquisa de campo em psicologia social: uma perspectiva pósconstrucionista. Psicologia \& Sociedade, 15(2), 18-42.

Sprenkle, D. H. \& Blow, A. J. (2004). Common factors and our sacred models. Journal of Marital and Family Therapy, 3o(2), 113-129.

Solomonov, N., Kuprian, N., Zilcha-Mano, S., Gorman, B. S., \& Basber, J. P. (2016). What do psychotherapy experts actually do in their sessions? An analysis of psychotherapy integration in prototypical demonstrations. Journal of Psychotherapy Integration, 26, 202-216. doi 10.1037/intooooo21

Strong, T. \& Gale, J. (2013). Postmodern clinical research: In and out the margins. Journal of Systemic Therapies, 32(2), 46-57.

Strong, T. (2002). Collaborative "expertise" after the discursive turn. Journal of Psychotherapy Integration, 12(2), 218-232. DOI 10.1037/1053-0479.12.2.218

Tomm, K. (1988). Interventive Interviewing: Part III. Intending to ask lineal, circular, strategic or reflexive questions? Family Process, 27, 1-15. doi.org/10.1111/j.1545-5300.1988.00001.x

Vasconcellos, M. J. E. (2002). Pensamento sistêmico: o novo paradigma da ciência. Campinas, SP: Papirus.

Vasconcellos, M. J. E. (2009). Cibernética e terapia familiar: que relação distinguimos hoje? In L. C. Osório \& M. E. P. Valle (Orgs.). Manual de Terapia Familiar (pp. 150-63). Porto Alegre: Artmed. 
Vicente, A. T., \& Pereira, M. F. (2001). Terapia centrada nos pedidos e nos recursos: um modelo de atendimento. Cadernos de Familiae IV, 17, 17-23.

Von Foerster, E. (1991). Comentário introductório a la parte II: La cibernética de segundo orden. In M. Pakman (Org.). Las semillas de la cibernética: obras escogidas de Heinz Von Foerster (pp. 83-88). Barcelona: Gedisa.

White, M., \& Epston, D. (1980). Narrative means to therapeutic ends. New York: W. W. Norton Publishers.

White, M. (2012). Mapas da Prática Narrativa. Porto Alegre: Pacartes.

Wiener, N. (1970). Cibernética: ou controle e comunicação no animal e na máquina. São Paulo: EDUSP. (original publicado em 1948) 
Apêndices 


\section{Apêndice A}

\section{Questionário sobre trajetória profissional}

Idade:

Gênero: ( ) Feminino

( ) Masculino

Qual curso de ensino superior você frequentou?

Há quanto tempo é formada(o)?

Onde fez a formação em terapia familiar?

Há quanto tempo é formada(o) em terapia familiar?

O curso de formação tinha uma orientação teórica predominante? Qual?

Há quanto tempo você atende casais e famílias?

Fez outra especialização? Qual(ais)? 
Na sua prática em geral, qual(ais) teorias(s) ou prática(s) você utiliza?

( ) Teoria sistêmica

( ) Práticas narrativas

( ) Práticas colaborativas

( ) Processos reflexivos

( ) Psicodinâmica / psicanálise

( ) Comportamental

( ) Cognitivo-comportamental

( ) Humanista / existencial

( ) Psicodrama

( ) Psicoterapia corporal

( ) Outro(s) - especificar: 


\section{Apêndice B \\ Convite para participação}

\section{DESCRIÇÃo DA PESQUISA}

Buscaremos descrever os recursos técnicos e teóricos utilizados pelos terapeutas em seus atendimentos, visando compreender os aspectos que norteiam estas escolhas.

Nosso estudo tem uma orientação curiosa, respeitosa e investigativa a respeito da prática clínica. Não é um instrumento de avaliação depreciativa ou julgamento de valor acerca de suas condutas profissionais. Por constituir-se em uma pesquisa-ação, nosso interesse central é construir com a terapeuta conhecimentos válidos para a investigação da prática, de uma forma que a participante possa sentir-se confortável e empoderada em todas as fases do estudo. Buscamos construir um estudo com os terapeutas, e não sobre os terapeutas. Nesse sentido, o método que propomos tem um delineamento flexível, e poderá ser modificado à partir do trabalho conjunto entre terapeuta e pesquisadora.

Objetivo geral: Compreender como terapeutas familiares integram diferentes teorias e técnicas em seu cotidiano de atendimentos clínicos.

\section{Justificativa:}

A integração de práticas em terapia familiar é uma tendência no campo em todo o mundo. A literatura indica que esta integração está se desenvolvendo de forma mais complexa e sofisticada. Nosso interesse é investigar como estas práticas integrativas têm se desenvolvido na prática clínica cotidiana, e quais são suas implicações.

\section{Critérios de Inclusão}

1) Exercer, atualmente, a prática clínica de atendimento a casais e famílias;

2) Ter concluído a formação como terapeuta familiar, uma vez que nossa pesquisa não está relacionada a contextos de aprendizagem em TF.

\section{Etapas do Método:}

1) Contato da pesquisadora com terapeutas que possam participar.

2) Convite para participação.

3) Assinatura do Termo de Consentimento Livre e Esclarecido.

4) Responder ao Questionário sobre Formação Profissional, que busca caracterizar a trajetória profissional e orientações práticas e teóricas estudadas até o momento.

5) Formação de uma dupla de atendimento (terapeuta e pesquisadora).

6) Atendimento de uma família ou casal que aceite participar da pesquisa mediante apresentação prévia das condições de participação. Estas são:

a. As terapeutas terão liberdade de selecionar os clientes que serão convidados a fazer parte da pesquisa. Este convite poderá ser configurado de forma que a terapeuta sinta-se confortável e não coloque em risco sua imagem profissional.

b. Todos os clientes deverão assinar um Termo de Consentimento Livre e Esclarecido.

c. A atividade da pesquisadora e a participação na pesquisa serão voluntárias (não remuneradas).

d. Utilizaremos informações de dez sessões de atendimento. Como o foco da pesquisa é a atuação da terapeuta, as sessões serão registradas como informações da pesquisa mesmo que compreendam a participação da pesquisadora no atendimento de mais de uma família (por exemplo, em caso de desistência de uma família/casal, novos clientes serão convidados e as sessões efetuadas serão registradas até que somem 10 sessões). 
e. Cada sessão será gravada em áudio e posteriormente transcrita literal e integralmente. Caso a terapeuta e/ou os clientes sintam-se incomodados ou desconfortáveis com a gravação em áudio das sessões, propomos que a pesquisadora faça transcrições de memória das mesmas, com informações detalhadas de cada encontro.

f. A pesquisadora assumirá com a terapeuta e com os clientes o compromisso de fazer parte do processo terapêutico por tempo indeterminado.

7) Após o término das dez sessões, a terapeuta receberá as transcrições das sessões impressas, cuja leitura oferecerá subsídios para uma conversa entre a terapeuta e a pesquisadora.

8) Teremos uma conversa que denominamos Interlocução, norteada pelo interesse nas motivações que levaram à construção de determinadas intervenções, nas hipóteses teóricas que orientaram a prática e na construção de justificativas para as ações desenvolvidas. Estas conversas serão gravadas em áudio e posteriormente transcritas, e têm duração estimada entre uma e duas horas.

9) Esta conversa é a última etapa da participação da terapeuta no estudo. Todavia, a pesquisadora poderá continuar participando dos atendimentos, caso os participantes assim o desejarem.

Período estimado para a coleta de dados: Até dezembro de 2017.

\section{O que sua participação exigiria de você, em termos de tempo?}

$>$ Horário para a realização dos atendimentos.

> Horário para nosso(s) encontro(s) de Interlocução.

Observações adicionais: As informações serão utilizadas apenas para fins de pesquisa. Todas as gravações e transcrições serão armazenadas em arquivos impressos e eletrônicos até a finalização do estudo, e descartadas e deletadas após o término do mesmo. Serão utilizados nomes fictícios para que a identidade dos participantes seja mantida em sigilo, sobretudo na divulgação ou publicação do estudo.

Benefícios esperados para o campo da terapia familiar: Esperamos que nossos diálogos possam contribuir para a reflexão sobre a atuação em terapia familiar, buscando a construção de práticas mais potentes, críticas e reflexivas. Concebemos o terapeuta familiar como produtor de conhecimentos sobre sua própria prática, e também como um parceiro na construção da pesquisa. Além disso, ao construir conhecimentos no contexto da prática clínica, esperamos que este estudo aproxime a pesquisa acadêmica das vivências profissionais cotidianas.

Benefícios esperados para os clientes: Consideramos que as pessoas procuram a terapia de família como uma forma de auxílio para lidarem com situações problemáticas, e nosso estudo pode, potencialmente, contribuir para o oferecimento de serviços qualificados para a população em geral ao convidar os terapeutas para o exercício de uma prática crítica e reflexiva. 


\section{Apêndice $\mathbf{C}$ \\ Roteiro de Interlocução pós-atendimento - Anna}

\section{Sobre "como" estar aqui}

Anna, antes quero lhe falar um pouco sobre "como" estarmos juntas aqui nessa conversa. Eu não gostaria que nos preocupássemos em sair daqui com informações muito "organizadas" - eu gostaria que nos soltássemos para deixar as informações fluírem, o caos, a "bagunça", para podermos ter uma conversa criativa, espontânea. Depois, eu vou trabalhar sobre o material da nossa conversa e "organizá-lo" de uma forma que eu ache que faça sentido. Quando terminar, eu gostaria de mostrar essa análise para você, antes de torna-la definitiva para a tese, para que você me dê um feedback. Pode ser?

\section{Sobre as categorias de ações}

Anna, o foco desta conversa é compreender a prática nas sessões relatadas. Então, pensei em conversarmos sobre o material que você leu, buscando resgatar nossas vivências nas sessões - até por isso transcrevi alguns trechos.

Para ajudar na nossa conversa, você deve ter percebido que eu destaquei suas ações, mas o que estou chamando de ações? Foram atitudes diversas: postura corporal, entonação, levantar para pegar a caixa de lenço; e também comentários, perguntas e inclusive o "ouvir em silêncio".

Eu, Gabriela, estou pensando que por trás dessas ações há uma inspiração, que eu gostaria de chamar de recurso. $E$ alguns desses recursos me parecem andar próximos de teorias e métodos para a prática clínica. É sobre esses recursos que eu quero conversar com você, e talvez, juntas, nós possamos dar nomes para os recursos que você utiliza no seu cotidiano, pode ser?

Primeiro, gostaria de começar falando sobre o nome que eu dei para esses conjuntos de ações.

- Ao analisar as sessões, eu "classifiquei" suas ações. O que você achou desses nomes? Você acha que eles "fazem jus" à forma como você se vê atuando?

- Ao analisar as ações, eu pensei em trazer um material gráfico que nos oferecesse uma imagem visual (mostrar gráficos). Como foi ver estes gráficos? O que chama sua atenção? Você identifica pressupostos teóricos que possam estar embasando essa forma, esse seu estilo de atuar? Dito de outra forma: você identifica alguma inspiração para fazer isto que faz?

- Ainda sobre gráficos: Quando você olha essa análise, quais efeitos você imagina que esse estilo de atuar promove em um atendimento de casal?

- Como você acha que minha presença alterou sua atuação nesse atendimento? Percebeu alguma mudança? Qual(is)?

\section{Sobre os itens de cada categoria}

Nestas tabelas, eu procurei destacar algumas ações que eu imagino que tenham surgido a partir de alguma inspiração teórica. Eu sei que é bem provável que você não tenha, no momento da sessão, pensado conscientemente em nenhuma teoria. Mas eu agrupei algumas ações que me pareceram semelhantes entre elas, e que talvez indiquem uma inspiração teórica da sua parte.

- Retomando o contato com a transcrição da sessão, você identificou o uso de recursos de alguma teoria?

- Você consegue me dizer se houve algum critério que norteou a escolha deste recurso?

- Ao ler o material, você viu algo inesperado ou que chamou sua atenção? 
Bom, acho que podemos encerrar nossa conversa sobre os atendimentos por aqui. Tem mais alguma coisa que você gostaria de falar ou perguntar?

Por fim, eu gostaria de lhe fazer algumas perguntas sobre como foi participar de uma pesquisa-ação. Podemos fazer isso agora ou em outro dia. Você está cansada, quer continuar?

\section{Sobre participação em uma pesquisa-ação}

- Os objetivos da pesquisa-ação são: gerar informações que sejam válidas no cotidiano do participante; gerar informações válidas tanto para pesquisador quanto para o participante; e, por meio da participação na pesquisa, permitir que você aja de forma mais efetiva na situação investigada. Você acha que a sua participação na pesquisa esteve próxima destes objetivos? Como?

- A pesquisa busca contribuir diretamente para o desenvolvimento das pessoas. Você acha que nossa relação proporcionou algum desenvolvimento para você?

- Outra preocupação da pesquisa-ação é que o conhecimento é produzido na prática e para a prática. Que tipo de conhecimento eu posso gerar nessa pesquisa, que possa ser útil para outros terapeutas familiares que vão ler nosso trabalho? O que pode ser um conhecimento de qualidade para outros terapeutas familiares?

- Você se sentiu envolvida em um processo conjunto de construção do conhecimento?

- Você se sentiu convidada a se envolver em outros processos de investigação científica?

(Agradecer participação e valorizar a disponibilidade e atenção em todo o processo) 


\section{Apêndice D}

\section{Roteiro de Interlocução pós-atendimento - Lina}

\section{Sobre "como" estar aqui}

Lina, antes quero lhe falar um pouco sobre "como" estarmos juntas aqui nessa conversa. Eu não gostaria que nos preocupássemos em sair daqui com informações muito "organizadas" - eu gostaria que nos soltássemos para deixar as informações fluírem, o caos, a "bagunça”, para podermos ter uma conversa criativa, espontânea. Depois, eu vou trabalhar sobre o material da nossa conversa e "organizá-lo" de uma forma que eu ache que faça sentido. Quando terminar, eu gostaria de mostrar essa análise para você, antes de torna-la definitiva para a tese, para que você me dê um feedback. Pode ser?

\section{Sobre as categorias de ações}

Lina, o foco desta conversa é compreender a prática nas sessões relatadas. Então, pensei em conversarmos sobre o material que você leu, buscando resgatar nossas vivências nas sessões - até por isso transcrevi alguns trechos.

Para ajudar na nossa conversa, você deve ter percebido que eu destaquei suas accões, mas o que estou chamando de ações? Foram atitudes diversas: postura corporal, entonação, levantar para pegar a caixa de lenço; e também comentários, perguntas e inclusive o "ouvir em silêncio".

Eu, Gabriela, estou pensando que por trás dessas ações há uma inspiração, que eu gostaria de chamar de recurso. E alguns desses recursos me parecem andar próximos de teorias e métodos para a prática clínica. É sobre esses recursos que eu quero conversar com você, e talvez, juntas, nós possamos dar nomes para os recursos que você utiliza no seu cotidiano, pode ser?

Primeiro, gostaria de começar falando sobre o nome que eu dei para esses conjuntos de ações.

- Ao analisar as sessões, eu "classifiquei" suas ações entre: exploratórias-investigativas, construção de visões relacionais (sobre problema, pessoa e mudança), intervenção, construção da comunicação em contexto e operacionais. $O$ que você achou desses nomes? Você acha que eles "fazem jus" à forma como você se vê atuando?

- Ao analisar as ações, eu pensei em trazer um material gráfico que nos oferecesse uma imagem visual (mostrar gráficos). Como foi ver estes gráficos? O que chama sua atenção? Você identifica pressupostos teóricos que possam estar embasando essa forma, esse seu estilo de atuar? Dito de outra forma: você identifica alguma inspiração para fazer isto que faz?

- Ainda sobre gráficos: Quando você olha essa análise, quais efeitos você imagina que esse estilo de atuar promove em um atendimento?

- Como você acha que minha presença alterou sua atuação nesse atendimento? Qual(is) mudança(s) percebeu?

\section{Sobre os itens de cada categoria}

Nestas tabelas, eu procurei destacar algumas ações que eu imagino que tenham surgido a partir de alguma inspiração teórica. Eu sei que é bem provável que você não tenha, no 
momento da sessão, pensado conscientemente em nenhuma teoria. Mas eu agrupei algumas ações que me pareceram semelhantes entre elas, e que talvez indiquem uma inspiração teórica da sua parte.

- Retomando o contato com a transcrição da sessão, você identificou o uso de recursos de alguma teoria?

- Você consegue me dizer se houve algum critério que norteou a escolha deste recurso?

- Ao ler o material, você viu algo inesperado ou que chamou sua atenção?

Bom, acho que podemos encerrar nossa conversa sobre os atendimentos por aqui. Tem mais alguma coisa que você gostaria de falar ou perguntar?

Por fim, eu gostaria de lhe fazer algumas perguntas sobre como foi participar de uma pesquisa-ação. Podemos fazer isso agora ou em outro dia. Você está cansada, quer continuar?

\section{Sobre participação em uma pesquisa-ação}

- Os objetivos da pesquisa-ação são: gerar informações que sejam válidas no cotidiano do participante; gerar informações válidas tanto para pesquisador quanto para 0 participante; e, por meio da participação na pesquisa, permitir que você aja de forma mais efetiva na situação investigada. Você acha que a sua participação na pesquisa esteve próxima destes objetivos? Como?

- A pesquisa busca contribuir diretamente para o desenvolvimento das pessoas. Você acha que nossa relação proporcionou algum desenvolvimento para você?

- Outra preocupação da pesquisa-ação é que o conhecimento é produzido na prática e para a prática. Que tipo de conhecimento eu posso gerar nessa pesquisa, que possa ser útil para outros terapeutas familiares que vão ler nosso trabalho? O que pode ser um conhecimento de qualidade para outros terapeutas familiares?

- Você se sentiu envolvida em um processo conjunto de construção do conhecimento?

- Você se sentiu convidada a se envolver em outros processos de investigação científica?

(Agradecer participação e valorizar a disponibilidade e atenção em todo o processo) 


\section{Apêndice E}

\section{Termo de Consentimento Livre e Esclarecido - Terapeutas}

Você está sendo convidado(a) para participar da pesquisa "A integração de práticas clínicas por terapeutas familiares”, realizada pela psicóloga, terapeuta familiar e estudante de Doutorado Gabriela Silveira de Paula-Ravagnani, sob orientação da

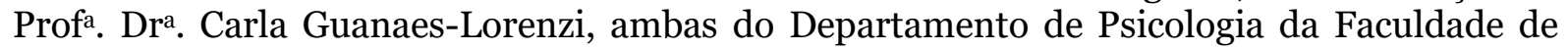
Filosofia, Ciências e Letras de Ribeirão Preto.

O objetivo da pesquisa é compreender como terapeutas familiares integram diferentes teorias e técnicas em seu cotidiano de atendimentos clínicos. As pesquisadoras estão interessadas em descrever os recursos técnicos e teóricos utilizados pelos terapeutas em seus atendimentos, buscando compreender os aspectos que norteiam estas escolhas.

Ao aceitar fazer parte desta pesquisa, solicitaremos que você responda um questionário sobre sua formação profissional (graduação, formação em terapia familiar e outras especializações), através do qual buscaremos caracterizar sua trajetória e as orientações práticas e teóricas estudadas até o presente momento.

Após esta etapa, você e a pesquisadora formarão uma dupla de atendimento, e atenderão uma família ou casal que aceite participar do estudo mediante apresentação prévia das condições de participação. A atividade da pesquisadora será voluntária e não envolverá remuneração. Para a realização do estudo, utilizaremos informações de dez sessões de atendimento, que serão gravadas em áudio e posteriormente transcritas literal e integralmente. Caso você e/ou os clientes sintam-se incomodados ou desconfortáveis com a gravação em áudio das sessões, propomos que a pesquisadora faça transcrições de memória das mesmas, com informações detalhadas de cada encontro. Após o término das dez sessões, a pesquisadora entregará a você um arquivo impresso contendo estas transcrições, cuja leitura oferecerá subsídios para uma conversa entre você e a pesquisadora. Nesta conversa, que denominamos Interlocução e tem duração estimada de duas horas, buscaremos criar uma visão conjunta sobre o processo terapêutico, norteadas pelo interesse nas motivações que levaram à construção de determinadas intervenções, nas hipóteses teóricas que orientaram a prática e na construção de justificativas para as ações desenvolvidas. Esta conversa será gravada em áudio e posteriormente transcrita literal e integralmente pela pesquisadora. Esta conversa é a última etapa de sua participação no estudo. Todavia, a pesquisadora assumirá com você e com os clientes o compromisso de fazer parte do processo terapêutico por tempo indeterminado, até que este seja finalizado.

As informações reunidas ao longo do estudo serão utilizadas apenas para fins de pesquisa. Todas as gravações e transcrições realizadas serão armazenadas em arquivos impressos e eletrônicos até a finalização do estudo, e serão descartados e deletados após o término do mesmo. Serão utilizados nomes fictícios para que a identidade dos participantes seja mantida em sigilo, sobretudo na divulgação ou publicação do estudo.

Sua participação é voluntária e não lhe ocasionará gastos financeiros. Portanto, esta participação não envolve remuneração ou ajuda de custo por parte das pesquisadoras. Você poderá desistir de participar a qualquer momento, sem que isso lhe traga qualquer prejuízo. Esta participação não oferece riscos previsíveis à sua saúde. Como dissemos anteriormente, é possível que a gravação em áudio das sessões de atendimento ocasionem desconforto em você e/ou nos clientes, e oferecemos a possibilidade de transcrição de memória das sessões como uma forma de evitar este desconforto.

Você poderá entrar em contato com as pesquisadoras a qualquer momento para buscar assistência ou esclarecimentos, mesmo após o término da pesquisa. Além disso, se desejar obter esclarecimentos sobre os procedimentos éticos do estudo, poderá entrar em contato com o Comitê de Ética em Pesquisa da Faculdade de Filosofia, Ciências e Letras de Ribeirão Preto - USP, localizado na Avenida Bandeirantes, $n^{\circ} 3900$, Bloco 23, casa 37, CEP. 14040-901, Ribeirão Preto (SP), telefones: (16) 3315-4811 e 3315-9101 (fax), e-mail: coetp@ffclrp.usp.br. 
Esperamos que o estudo contribua para o campo da terapia familiar ao construir conhecimentos no contexto da prática clínica, aproximando a pesquisa das vivências profissionais cotidianas. Concebemos o terapeuta familiar como produtor de conhecimentos sobre sua própria prática, e também como um parceiro na construção da pesquisa. Assim, esperamos que nossos diálogos possam contribuir para reflexões sobre suas próprias atuações, buscando a construção de práticas mais potentes, críticas e reflexivas.

Serão assinadas duas vias deste termo, sendo que uma ficará com você e outra será entregue para a pesquisadora.

Esclarecido e concordando com o que foi colocado:

$\mathrm{Eu}$,

aceito participar da pesquisa “A integração de práticas clínicas por terapeutas familiares”. de de 201

Assinatura:

Endereço para contato:

Assinatura:

Assinatura:

Pesquisadora: Profa. Dra. Carla Guanaes Lorenzi

Pesquisadora: Gabriela Silveira de Paula Ravagnani

Endereço para contato com as pesquisadoras:

Faculdade de Filosofia, Ciências e Letras de Ribeirão Preto - USP. Departamento de Psicologia.

Av. Bandeirantes, 3900. Bairro Monte Alegre - Ribeirão Preto - SP. CEP: 14040-901.

Telefones: (16) 3602-4446 (Carla Guanaes Lorenzi); (16) 98137-9379 (Gabriela S. P. Ravagnani). 


\section{Apêndice F}

\section{Termo de Consentimento Livre e Esclarecido - Clientes}

Você está sendo convidado(a) para participar da pesquisa "A integração de práticas clínicas por terapeutas familiares”, realizada pela psicóloga, terapeuta familiar e estudante de Doutorado Gabriela Silveira de Paula-Ravagnani, sob orientação da

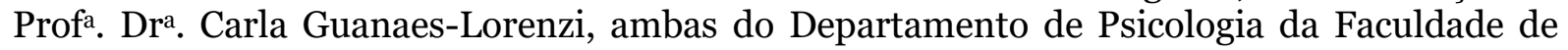
Filosofia, Ciências e Letras de Ribeirão Preto.

O objetivo da pesquisa é compreender como terapeutas familiares integram diferentes teorias e técnicas em seu cotidiano de atendimentos clínicos. As pesquisadoras estão interessadas em descrever os recursos técnicos e teóricos utilizados pelos terapeutas em seus atendimentos, buscando compreender os aspectos que norteiam estas escolhas.

Ao aceitar fazer parte desta pesquisa, você será atendido por uma dupla de terapeutas formada pela pesquisadora e o(a) terapeuta, que também estará participando do estudo. A atividade da pesquisadora será voluntária e não envolverá remuneração. Para a realização do estudo, utilizaremos as informações de dez sessões de atendimento. Caso você permaneça em terapia por um período inferior a dez sessões, utilizaremos as informações do número de sessões realizadas. Cada sessão será gravada em áudio e posteriormente transcrita literal e integralmente. Se você e/ou o terapeuta sentirem-se incomodados com a gravação em áudio das sessões, propomos que a pesquisadora faça transcrições de memória das mesmas, com informações detalhadas de cada encontro. Após o término das sessões realizadas, a pesquisadora e o(a) terapeuta farão uma conversa a respeito da prática clínica de ambos(as). Esta conversa será norteada pelo interesse na atuação profissional dos terapeutas e as teorias que embasaram sua prática.

Sua participação no estudo implica que a pesquisadora assumirá com você e com o(a) terapeuta o compromisso de fazer parte do processo terapêutico por tempo indeterminado, até que este seja finalizado.

As informações reunidas ao longo do estudo serão utilizadas apenas para fins de pesquisa. Todas as gravações e transcrições realizadas serão armazenadas em arquivos impressos e eletrônicos até a finalização do estudo, e serão descartados e deletados após o término do mesmo. Serão utilizados nomes fictícios para que a identidade dos participantes seja mantida em sigilo, sobretudo na divulgação ou publicação do estudo.

Sua participação é voluntária e não lhe ocasionará gastos financeiros. Portanto, esta participação não envolve remuneração ou ajuda de custo por parte das pesquisadoras. Você poderá desistir de participar a qualquer momento, sem que isso lhe traga qualquer prejuízo. Esta participação não oferece riscos previsíveis à sua saúde. Como dissemos anteriormente, é possível que a gravação em áudio das sessões de atendimento ocasionem desconforto em você e/ou no terapeuta, e oferecemos a possibilidade de transcrição de memória das sessões como uma forma de evitar este desconforto.

Você poderá entrar em contato com as pesquisadoras a qualquer momento para buscar assistência ou esclarecimentos, mesmo após o término da pesquisa. Além disso, se desejar obter esclarecimentos sobre os procedimentos éticos do estudo, poderá entrar em contato com o Comitê de Ética em Pesquisa da Faculdade de Filosofia, Ciências e Letras de Ribeirão Preto - USP, localizado na Avenida Bandeirantes, $n^{\circ} 3900$, Bloco 23, casa 37, CEP. 14040-901, Ribeirão Preto (SP), telefones: (16) 3315-4811 e 3315-9101 (fax), e-mail: coetp@ffclrp.usp.br.

Esperamos que o estudo contribua para o campo da terapia familiar ao construir conhecimentos no contexto da prática clínica, aproximando a pesquisa das vivências profissionais cotidianas. Consideramos que as pessoas procuram a terapia de família como uma forma de auxílio para lidarem com situações problemáticas, e nosso estudo pode, potencialmente, contribuir para o oferecimento de serviços qualificados para a população em geral ao convidar os terapeutas para o exercício de uma prática crítica e reflexiva.

Serão assinadas duas vias deste termo, sendo que uma ficará com você e outra será entregue para a pesquisadora. 
Esclarecido e concordando com o que foi colocado:

$\mathrm{Eu}$,

aceito participar da pesquisa “A integração de práticas clínicas por terapeutas familiares”.

de

de 201

Assinatura:

Endereço para contato

Assinatura:

Assinatura:

Pesquisadora: Profa. Dra. Carla Guanaes Pesquisadora: Gabriela Silveira de Paula Lorenzi Ravagnani

Endereço para contato com as pesquisadoras:

Faculdade de Filosofia, Ciências e Letras de Ribeirão Preto - USP. Departamento de Psicologia.

Av. Bandeirantes, 3900. Bairro Monte Alegre - Ribeirão Preto - SP. CEP: 14040-901.

Telefones: (16) 3602-4446 (Carla Guanaes Lorenzi); (16) 98137-9379 (Gabriela S. P. Ravagnani). 


\section{Apêndice G \\ Termo de Consentimento para Composição de Banco de Dados Terapeutas}

Você está sendo convidado(a) para participar da pesquisa "A integração de práticas clínicas por terapeutas familiares", realizada pela psicóloga, terapeuta familiar e estudante de Doutorado Gabriela Silveira de Paula-Ravagnani, sob orientação da Profa $^{a}$. Dra ${ }^{a}$ Carla Guanaes-Lorenzi, ambas do Departamento de Psicologia da Faculdade de Filosofia, Ciências e Letras de Ribeirão Preto. O objetivo da pesquisa é compreender como terapeutas familiares integram diferentes teorias e técnicas em seu cotidiano de atendimentos clínicos.

Entendendo que você participará da pesquisa "A integração de práticas clínicas por terapeutas familiares", pois já leu e assinou o Termo de Consentimento Livre e Esclarecido, o propósito deste documento é solicitar sua permissão para que todas as informações que coletamos junto à você possam ser guardadas, com o objetivo de constituir o que nós, pesquisadores, chamamos de "banco de dados". Banco de dados é o armazenamento das informações de uma pesquisa, como esta que estou realizando, para que estas informações possam ser utilizadas em outras pesquisas científicas na mesma área.

Isso significa que as informações das sessões (gravações em áudio ou transcrições de memória feitas pela pesquisadora) serão arquivadas e poderão ser utilizadas como material em pesquisas futuras que possam abordar outros aspectos do mesmo tema. A Profa. Dra. Carla Guanaes-Lorenzi, do Departamento de Psicologia da FFCLRP - USP, declara-se como responsável institucional desse banco de dados. Para informações quanto aos resultados obtidos através da utilização de seus dados, você poderá entrar em contato através do endereço: Avenida dos Bandeirantes, 3900. Bairro Monte Alegre. Ribeirão Preto - SP, ou pelo telefone (016) 3602-4446.

Sua participação na composição desse banco de dados é voluntária, não havendo nenhum tipo de remuneração. A divulgação deste material preservará o sigilo de sua identidade, e seus dados serão descaracterizados ao máximo, para impedir a sua identificação.

Você poderá entrar em contato com as pesquisadoras a qualquer momento para buscar assistência ou esclarecimentos sobre a utilização deste banco de dados, mesmo após o término da pesquisa. Além disso, se desejar obter esclarecimentos sobre os procedimentos éticos do estudo, poderá entrar em contato com o Comitê de Ética em Pesquisa da Faculdade de Filosofia, Ciências e Letras de Ribeirão Preto - USP, localizado na Avenida Bandeirantes, $\mathrm{n}^{\circ}$ 3900, Bloco 23, casa 37, CEP. 14040-901, Ribeirão Preto (SP), telefones: (16) 3315-4811 e 3315-9101 (fax), e-mail: coetp@ffclrp.usp.br.

Serão assinadas duas vias deste termo, sendo que uma ficará com você e outra será entregue para a pesquisadora. 
Esclarecido e concordando com o que foi colocado:

$\mathrm{Eu}$,

aceito participar da pesquisa "A integração de práticas clínicas por terapeutas familiares”, e aceito o arquivamento das informações coletadas nessa pesquisa em um banco de dados, bem como sua utilização em estudo (s) científico (s) posterior (es), sempre de modo a NÃO me identificar.

( ) Quero ser avisado todas as vezes que meus dados forem utilizados em pesquisas futuras;

( ) Não quero ser avisado quando meus dados forem utilizados em pesquisas futuras.

de de 201

Assinatura:

Endereço para contato:

Assinatura:

Pesquisadora: Profa. Dra. Carla Guanaes Lorenzi
Assinatura:

Pesquisadora: Gabriela Silveira de Paula Ravagnani

Endereço para contato com as pesquisadoras:

Faculdade de Filosofia, Ciências e Letras de Ribeirão Preto - USP. Departamento de Psicologia.

Av. Bandeirantes, 3900. Bairro Monte Alegre - Ribeirão Preto - SP. CEP: 14040-901.

Telefones: (16) 3602-4446 (Carla Guanaes Lorenzi); (16) 98137-9379 (Gabriela S. P. Ravagnani). 


\section{Apêndice $\mathbf{H}$ \\ Termo de Consentimento para Composição de Banco de Dados Clientes}

Você está sendo convidado(a) para participar da pesquisa "A integração de práticas clínicas por terapeutas familiares", realizada pela psicóloga, terapeuta familiar e estudante de Doutorado Gabriela Silveira de Paula-Ravagnani, sob orientação da Profa. Dra ${ }^{\text {a }}$ Carla Guanaes-Lorenzi, ambas do Departamento de Psicologia da Faculdade de Filosofia, Ciências e Letras de Ribeirão Preto. O objetivo da pesquisa é compreender como terapeutas familiares integram diferentes teorias e técnicas em seu cotidiano de atendimentos clínicos.

Entendendo que você participará da pesquisa “A integração de práticas clínicas por terapeutas familiares", pois já leu e assinou o Termo de Consentimento Livre e Esclarecido, o propósito deste documento é solicitar sua permissão para que todas as informações que coletamos junto à você possam ser guardadas, com o objetivo de constituir o que nós, pesquisadores, chamamos de "banco de dados". Banco de dados é o armazenamento das informações de uma pesquisa, como esta que estou realizando, para que estas informações possam ser utilizadas em outras pesquisas científicas na mesma área.

Isso significa que as informações das sessões (gravações em áudio ou transcrições de memória feitas pela pesquisadora) serão arquivadas e poderão ser utilizadas como material em pesquisas futuras que possam abordar outros aspectos do mesmo tema. A Profa. Dra. Carla Guanaes-Lorenzi, do Departamento de Psicologia da FFCLRP - USP, declara-se como responsável institucional desse banco de dados. Para informações quanto aos resultados obtidos através da utilização de seus dados, você poderá entrar em contato através do endereço: Avenida dos Bandeirantes, 3900. Bairro Monte Alegre. Ribeirão Preto - SP, ou pelo telefone (016) 3602-4446.

Sua participação na composição desse banco de dados é voluntária, não havendo nenhum tipo de remuneração. A divulgação deste material preservará o sigilo de sua identidade, e seus dados serão descaracterizados ao máximo, para impedir a sua identificação.

Você poderá entrar em contato com as pesquisadoras a qualquer momento para buscar assistência ou esclarecimentos sobre a utilização deste banco de dados, mesmo após o término da pesquisa. Além disso, se desejar obter esclarecimentos sobre os procedimentos éticos do estudo, poderá entrar em contato com o Comitê de Ética em Pesquisa da Faculdade de Filosofia, Ciências e Letras de Ribeirão Preto - USP, localizado na Avenida Bandeirantes, $\mathrm{n}^{\circ}$ 3900, Bloco 23, casa 37, CEP. 14040-901, Ribeirão Preto (SP), telefones: (16) 3315-4811 e 3315-9101 (fax), e-mail: coetp@ffclrp.usp.br.

Serão assinadas duas vias deste termo, sendo que uma ficará com você e outra será entregue para a pesquisadora. 
Esclarecido e concordando com o que foi colocado:

$\mathrm{Eu}$,

aceito participar da pesquisa "A integração de práticas clínicas por terapeutas familiares", e aceito o arquivamento das informações coletadas nessa pesquisa em um banco de dados, bem como sua utilização em estudo (s) científico (s) posterior (es), sempre de modo a NÃO me identificar.

( ) Quero ser avisado todas as vezes que meus dados forem utilizados em pesquisas futuras;

( ) Não quero ser avisado quando meus dados forem utilizados em pesquisas futuras.

de de 201

Assinatura:

Endereço para contato:

Assinatura:

Pesquisadora: Profa. Dra. Carla Guanaes Lorenzi
Assinatura:

Pesquisadora: Gabriela Silveira de Paula Ravagnani

Endereço para contato com as pesquisadoras:

Faculdade de Filosofia, Ciências e Letras de Ribeirão Preto - USP. Departamento de Psicologia.

Av. Bandeirantes, 3900. Bairro Monte Alegre - Ribeirão Preto - SP. CEP: 14040-901.

Telefones: (16) 3602-4446 (Carla Guanaes Lorenzi); (16) 98137-9379 (Gabriela S. P. Ravagnani). 


\section{Apêndice I \\ Termo de Consentimento Livre e Esclarecido para constituição de banco de dados a ser armazenado pela terapeuta}

Você está recebendo atendimentos na modalidade de terapia familiar e/ou de casal, em sessões periódicas com as psicólogas e terapeutas de família Anna e Gabriela Silveira de Paula Ravagnani. As sessões estão sendo realizadas de forma gratuita, ou seja, as terapeutas não serão remuneradas monetariamente pela prestação de seus serviços. Por meio de seu consentimento, as sessões estão sendo gravadas em áudio, através de aparelho mp3. Após as sessões, as terapeutas discutem as questões tratadas na terapia, em uma conversa privada e sigilosa, a qual também é gravada em áudio.

Por meio deste Termo de Consentimento, solicitamos sua permissão para utilizar as informações gravadas das sessões e das conversas entre as terapeutas, para fins didáticos e de divulgação da prática clínica em meios técnico-científicos. A divulgação deste material preservará o sigilo de sua identidade, e seus dados serão descaracterizados ao máximo, para impedir a sua identificação. Por exemplo, nomes, lugares e profissão serão omitidos ou apresentados de forma genérica. Outras informações específicas que possam identificar as pessoas serão omitidas.

Lembramos que sua autorização é voluntária. Caso você concorde agora e decida desistir depois, você poderá comunicar sua decisão às terapeutas para assinatura de um termo de desistência. As terapeutas se comprometem a estar sempre disponíveis para esclarecer dúvidas e prestar assistência necessária. O Conselho Regional de Psicologia também poderá ser contatado para esclarecimentos adicionais. A utilização das informações estará de acordo com o que estabelece o Código de Ética Profissional do Psicólogo.

\section{Permissão para utilização das informações dos atendimentos com as psicólogas}

$\mathrm{Eu}$, portador(a) do documento de identificação número por meio deste documento, autorizo a utilização das informações dos atendimentos clínicos para fins de divulgação técnico-científica (tais como manuais técnicos, aulas, comunicações ou publicações acadêmicas), sendo que dados de identificação pessoal serão omitidos ou alterados.

Este documento é assinado em duas vias de igual teor.

( ) Quero ser avisado todas as vezes que meus dados forem utilizados.

( ) Não quero ser avisado quando meus dados forem utilizados.

Cidade, de de

Assinatura do(a) participante

Anna

(informações de contato)
Gabriela Silveira de Paula Ravagnani

Psicóloga (CRP 06/108416)

(informações de contato) 
Anexos 


\section{Anexo A}

\section{Ofício de aprovação do Comitê de Ética em Pesquisa da FFCLRP-USP}

Universidade de São Paulo

Faculdade de Filosofia, Ciências e Letras de Ribeirão Preto

Comitê de Ética em Pesquisa

Of.CEtP/FFCLRP-USP/124/-dgfs

Campus de Ribeirão Preto

Ribeirão Preto, 22 de dezembro de 2015

Prezada Pesquisadora,

Comunicamos a V. Sa. que o projeto de pesquisa intitulado "A Integração de Práticas Clínicas por Terapeutas Familiares" foi aprovado ad referendum do Comitê de Ética em Pesquisa da FFCLRP-USP e enquadrado na categoria: APROVADO (CAAE n. ${ }^{\circ} 51065815.0 .0000 .5407$ ).

Solicitamos que eventuais modificações ou emendas ao projeto de pesquisa sejam apresentadas ao CEP, de forma sucinta, identificando a parte do projeto a ser modificada e suas justificativas, e que, ao término do estudo, um relatório final seja entregue, via Plataforma Brasil.
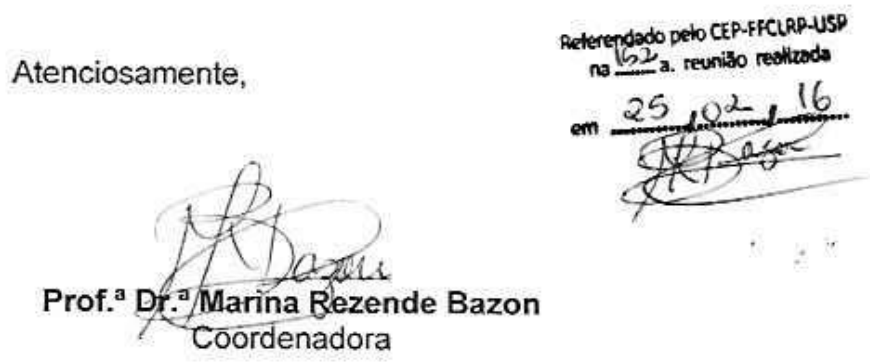

À Senhora

Gabriela Silveira de Paula Ravagnani

Programa de Pós-graduação em Psicologia da FFCLRP/USP

\footnotetext{
CEP - Comité de Ética em Pesquisa da FFCLRP USP

Fone: (16) 3315-4811 / Fax: (16) 3315-9101

Avenida Bandeirantes, 3900 - bloco 23 - casa 37 - 14040-901 - Ribeirăo Preto - SP - Brasil

Homepage: http://umw.ffcirp.usp.br - e-mail; coetp@uffelrp.usp.br
} 